ARGONNE CANCER RESEARCH HOSPITAL 950 EAST FIFTY-NINTH STREET - CHICAGO 37 • ILLINOIS

\title{
Semiannual Report to \\ THE ATOMIC ENERGY COMMISSION STUDIES ON ERYTHROPOIESIS
}

\author{
SEPTEMBER 1957 \\ LEON O. JACOBSON, M.D. \\ Editor \\ ANTREEN PFAU \\ Associate Editor
}

OPERATED BY THE UNIVERSITY OF CHICAGO

UNDER

CONTRACT AT-(11-1)-69 


\section{DISCLAIMER}

This report was prepared as an account of work sponsored by an agency of the United States Government. Neither the United States Government nor any agency Thereof, nor any of their employees, makes any warranty, express or implied, or assumes any legal liability or responsibility for the accuracy, completeness, or usefulness of any information, apparatus, product, or process disclosed, or represents that its use would not infringe privately owned rights. Reference herein to any specific commercial product, process, or service by trade name, trademark, manufacturer, or otherwise does not necessarily constitute or imply its endorsement, recommendation, or favoring by the United States Government or any agency thereof. The views and opinions of authors expressed herein do not necessarily state or reflect those of the United States Government or any agency thereof. 


\section{DISCLAIMER}

Portions of this document may be illegible in electronic image products. Images are produced from the best available original document. 


\section{LEGAL NOTICE}

This report was prepared as an account of Goverumeul spunsored work. Noithor the United States, nor the Commission, nor any person acling un behalf of the Commission:

A. Makes any warranty or representation, express or implied, with respect to lhe accuracy, completeness, or usefulness of the information contained in this report, or that the use of any information, apparatus, method, or process disclosed in this report may not infringe privately owned rights; or

B. Assumes any liabilities with respect to the use of, or for damages resulting from the use of any information, apparatus, method, or process disclosed in this report.

As used in the above, "person acting on behalf of the Commission" includes any employee or contractor of the Commission to the extent that such employee or contractor prepares, handles or distributes, or provides access to, any information pursuant to his employment or contract with the Commission.

Price $\$ 3.00$. Available from the Office of

Technical Services, Department of Commerce,

Washington 25, D.C. 
ARGONNE CANCER RESEARCH HOSPITAL 950 EAST FIFTY-NINTH STREET - CHICAGO 37 • ILLINOIS

\section{Semiannual Report to}

THE ATOMIC ENERGY COMMISSION

STUDIES ON ERYTHROPOIESIS

SEPTEMBER 1957

LEON O. JACOBSON, M.D.

Editor

ANTREEN PFAU

Associate Editor

OPERATED BY THE UNIVERSITY OF CHICAGO

UNDER

CONTRACT AT-(11-1)-69 


\section{PREFACE}

This collection of papers represents our efforts, over the past several years, that were directed toward obtaining a fuller understanding of the mechanism of the control of red blood cell formation. Our interest in this problem, aside from its intrinsic fascination, stemmed, in part, from our attempts to determine whether recovery from radiationinduced injury could be mediated by humoral mechanisms. Erythropoiesis is one of the vital processes inhibited by whole-body $\mathrm{X}$ irradiation; this inhibition being reversed during the recovery induced by spleen, embryo, or marrow cell transplants. Our attention, therefore, turned to the growing body of evidence indicating that a hormonal mechanism is involved in red blood cell formation.

The papers in this report are arranged roughly in the order of their publication, with some' as yet unpublished reports at the end. The course of the work is apparent: 'The first efforts were directed toward developing a simple and rapid assay method for erythropoietin. We then proceeded to the study of physiologic factors that control red cell formation through their effect on erythropoietin production. The well-known effect of cobalt in causing polycythemia was then investigated with the surprising finding that there was also a rapid response in the formation of erythropoietin. While the exact identity of the factor in "cobalt plasma" and that in "anemic plasma" still awaits the complete identification and characterization of erythropoietin, it seems safe to say that cobalt can induce erythropoietin production.

We then used the fact of the rapid response to cobalt as a tool to search for the site of production of erythropoietin. It is evident that our data, which indicate that the kidney is involved in erythropoiesis, are still indirect and that direct confirmation of the role of the kidney by demonstration of unequivocal activity in extracts is greatly needed. We are, of course, actively seeking such confirmation.

The clinical significance of erythropoietin has been investigated in a preliminary fashion by assay of human plasma from patients with a wide variety of disorders. Anemias may be accompanied by greater than normal plasma erythropoietin titers, normal or less than normal. The concept of a normal titer is still not well defined since no assay method yet can measure easily the erythropoietic effect of normal plasma. This last point is one alsio undergoing investigation. Those anemias with sub-normal titers are obviously the conditions that should be tested in clinical trials of erythropoietin.

Part of our efforts has been directed toward finding a more sensitive assay method that will lead to information concerning normal titers. Experiments using marrow cells in tissue culture have shown the feasibility of demonstrating stimulation of erythropoiesis in vitro but have not yet proved simple enough for our purposes.

Studies on the isolation and characterization of erythropoietin have followed two parallel paths. Along one we directed our attention to the purification of erythropoietin from the 
rabbit. These experiments are not reported at this time. Along the other path, in valuable collaboration with the Research Division of Armour and Company, we used anemic sheep as a source. Enough material with purity high enough for clinical testing will soon be available from this source. The last paper summarizes our joint efforts on the purification and characterization of sheep erythropoietin.

While none of the questions we have asked has yet been answered fully or finally, we feel that the study of erythropoiesis, both from a clinical and biologic viewpoint, may now be entering a new phase.

Apart from our published results, there has been another product derived from our work on erythropoiesis which needs emphasis. A formidable number of medical students took part in the work and made important contributions to it. But more importantly, they were able to have a rewarding experience in research that might otherwise have been unavailable to them. The following people who at one time or another were students, either medical or graduate, participated in this problem: W. Fried, L. Plzak, E. Anderson, K. Kelly, J. David, S. Krantz, R. Grant, D. Schlessinger, G. Humphrey, E. Filmanowicz, and W. Normore.

Mention must also be made of our debt to the following for technical help above and beyond the call of duty: M. Robșon, I. Henningsen, C. Carter, A. Birins, M. Cassman, and D. Mitchell.

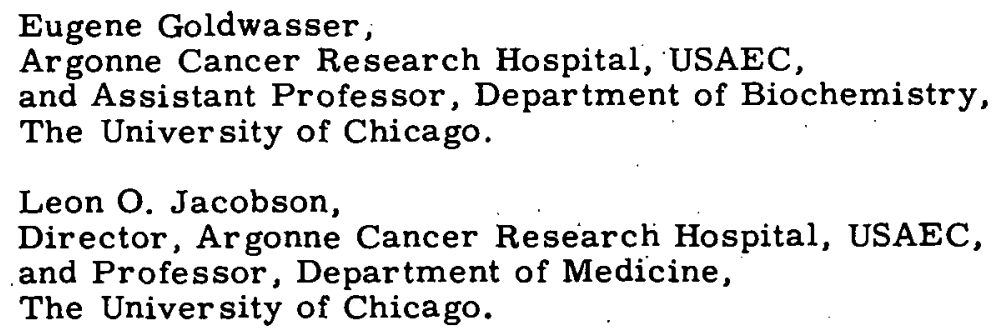


TABLE OF CONTENTS

Studies on erythropoiesis. I. Demonstration of stimulation of erythropoiesis by plasma from anemic rats using $\mathrm{Fe}^{59}$.

L. F. Plzak, W. Fried, L. O. Jacobson, and W. Bethard . . . . . . . . 1

Studies on erythropoiesis. II. Assay of erythropoietin in hypophysectomized rats.

W. Fried, L. Plzak, L. O. Jacobson, and E. Goldwasser . . . . . . . . . .

Studies on erythropoiesis. III. Factors controlling erythropoietin production.

W. Fried, L. F. Plzak', L. O. Jacobson, and E. Goldwasser . . . . . . . . . .

Studies on erythropoiesis. IV. Reticulocyte response of hypophysectomized and polycythemic rodents to erythropoietin.

L. O. Jacobson, E. Goldwasser, L. F. Plzak, and W. Fried . . . . . . . .

Studies on erythropoiesis. V. The effect of cobalt on the production of erythropoietin.

E. Goldwasser, L. O. Jacobson, W. Fried, and L. F. Plzak . . . . . . .

Studies on erythropoiesis. VI: Erythropoietin in human plasma.

C. W. Gurney, E. Goldwasser, and C. Pan ................

Studies on erythropoiesis. VII. The role of the kidney in the production of erythropoietin.

L. O. Jacobson, E. Goldwasser, W. Fried, and L. F. Plzak . . . . . . . .

Studies on erythropoiesis. VIII. The effect of nephrectomy on response to hypoxic anoxia.

E. Goldwasser, W. Fried, and L. O. Jacobson ..............

Studies on erythropoiesis. IX. The mechanism of decreased erythropoiesis in experimental polycythemia.

C. W. Gurney and C. Pan ....................

Studies on erythropoiesis. $\mathrm{X}$. The use of bone marrow culture in demonstrating erythropoietin.

W. F. Rosse and C. W. Gurnery . . . . . . . . . . . . . .

Studies on erythropoiesis. XI. Reticulocyte response of transfusion-induced polycythemic mice to anemic plasma from nephrectomized mice and plasma from nephrectomized rats exposed to low oxygen.

L. O. Jacobson, E. K. Marks, E. O. Gaston, and E. Goldwasser . . . . . . .

Studies on erythropoiesis. XII. The effect of transfusion-induced polycythemia in the mother on the fetus.

L. O. Jacobson, E. K. Marks, and E. O. Gaston . . . . . . . . . .

Studies on erythropoiesis. XIII. A comparison of methods of bioassay of erythropoietin in human plasma.

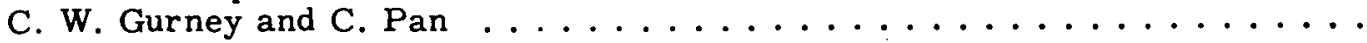


Studies on erythropoiesis. XIV. The relationship of humoral stimulation to iron absorption.

S. Krantz, E. Goldwasser, and L. O. Jacobson. . . . . . . . . . .

Studies on erythropoiesis. XV. The preparation of a highly purified erythropoietin from anemic sheep plasma.

W. F. White, R. Egan, R. J. Schlueter, G. F. Weber, and E. Goldwasser . . 130

Summary . . . . . . . . . . . . . . . . . . . . 149

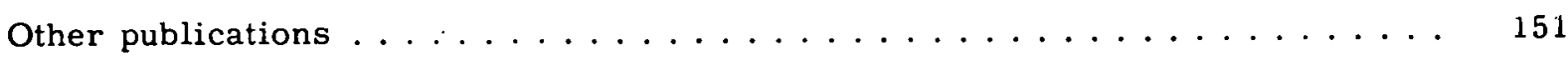




\section{STUDIES ON ERYTHROPOIESIS. I. DEMONSTRATION OF STIMULATION OF ERYTHROPOIESIS BY PLASMA FROM ANEMIC RATS USING $\mathrm{Fe}^{59 *}$}

By

L. F. Plzak, W. Fried, L. O. Jacobson, and W. F. Bethard ${ }^{\dagger}$.

\section{INTRODUCTION}

As early as 1906, Carnot and Deflandre ${ }^{1}$ suggested that a humoral factor in the blood plasma of rabbits mediates the production of red cells. In 1952, Grant and Root ${ }^{2}$ reviewed the pertinent literature and concluded that the most tenable theory of red cell production was that of humoral mediation. Since then, a great deal of evidence has been presented to substantiate this view. ${ }^{3-6}$ Most of the research has been done on the rabbit, with the reticulocyte, red blood cell, hemoglobin, and hematocrit values being used as indicators of erythropoietic response.

The presence of such a humoral factor in the blood plasma of the rat is described in this paper. Erythropoietic activity was determined by measuring the rate of appearance of intravenously administered $\mathrm{Fe}^{59}$ in the peripheral blood of normal rats that had been previously injected intravenously with the substances that were to be tested.

\section{METHOD}

The $\mathrm{Fe}^{59}$ was obtained as ferric chloride in $0.08 \mathrm{~N} \mathrm{HCl}$ from Abbott Laboratories. Carrier iron was added as $\mathrm{FeCl}_{3}$; all solutions were diluted in saline and titrated to $\mathrm{pH} 6$ with saturated sodium citrate. Total iron was determined by the method of Barkan and Walker. ${ }^{7}$ Each animal received about $0.8 \mu \mathrm{c} \mathrm{Fe}{ }^{59}$, which was equivalent to approximately 400,000 counts per minute (c.p.m.) in a well-type scintillation counter. ${ }^{\ddagger}$ The radiotracer was given 2 to 5 hours after the last injection of the test material. Blood samples $(0.2 \mathrm{ml})$ were taken from a tail vein or by cardiac puncture at appropriate intervals to determine the concentration of $\mathrm{Fe}^{59}$ in the erythrocytes. The percentage of injected iron present in the peripheral blood was then calculated, assuming the total blood volume to be 5 per cent of the body weight (Table 1).

It has been shown that radioactive iron is removed from the plasma within 4 to 6 hours after injection. ${ }^{8}$ Furthermore, it has been found that $\mathrm{Fe}^{59}$ does not exchange with the iron that is already present in the red cell; ${ }^{8}$ nor is it adsorbed on the mature erythrocytes. ${ }^{9}$ Shortly after injection, it appears that the tracer begins to be incorporated into

\footnotetext{
* Reprinted from The Journal of Laboratory and Clinical Medicine, 46:671-78, 1955.

$\dagger$ Present address: Scripps Metabolic Clinic, La Jolla, San Diego, California.

‡ Nancy Wood Counter. Model 1050A.
} 
Table 1

PRE- AND POSTINJECTION BLOOD VOLUMES

\begin{tabular}{c|c|c|c}
\hline $\begin{array}{c}\text { Preinjection } \\
\text { blood volume } \\
\text { (\% of body weight) }\end{array}$ & Fluid injected & $\begin{array}{c}\text { Postinjection } \\
\text { blood volume } \\
\text { (\% of body weight) }\end{array}$ & $\begin{array}{c}\text { Per cent change } \\
\text { in blood volume }\end{array}$ \\
\hline 5.1 & Saline & 5.9 & +16 \\
5.1 & Normal plasma & 6.1 & +20 \\
5.1 & Anemic plasma & 5.9 & +16 \\
\hline
\end{tabular}

the maturing red cell. 10 Hence, the measured radioactivity in our samples was an indication of the amount of $\mathrm{Fe}^{59}$ contained in the newly formed erythrocytes, and thus this value was taken as a direct indication of the rate of erythropoiesis.

\section{THE EFFECT OF ANEMIC PLASMA, NORMAL PLASMA, AND}

\section{SALINE ON BLOOD VOLUME}

The data in this paper are based on the assumption that the blood volume at the time of sampling is not increased by the massive plasma injections. In order to verify this, an experiment was performed in which the blood volume of the recipients was determined after the injection of normal rat erythrocytes that had been labeled with $\mathrm{Na}_{2} \mathrm{Cr}^{51} \mathrm{O}_{4} . \mathrm{The}^{\circ}$ red cells were tagged with the radiotracer by the method of Gray and Sterling. 11

One milliliter of $\mathrm{Cr}^{51}$-labeled red cells was injected intravenously into a group of 4 month-old Strague-Dawley male rats. Twenty-four hours following the injection of the labeled red cells, the rats were weighed, and a $0.5 \mathrm{ml}$ sample of blood was withdrawn from each rat to establish the preinjection blood volume. These rats were divided into three groups: one to receive daily injections of pooled plasma from anemic rats (bled sufficiently to reduce the hematocrit to below 20 per cent); one to receive pooled normal rat plasma; and one, saline. The volumes injected intravenously on three successive days were 3 , 3 , and $4 \mathrm{ml}$. Twenty-four hours following the last injection, the rats were weighed, and a 0.5-ml sample of blood was taken by cardiac puncture from each of the recipients in order to determine the postinjection blood volume.

The data, presented in Table 1, show that there is no significant difference between the blood volumes of rats injected with saline and those injected with the plasmas.

These data also support the finding that in rats the blood volume is approximately 5 per cent of the total body weight.

It has been shown that $\mathrm{Cr}^{51}$ is lost from the red cell after 24 hours, 11 and this loss combined with erythrocyte destruction accounts for the "increase" in volume. Because intravenous injections of massive volumes of saline are completely cleared from an animal within several hours, the postinjection saline value represents the corrected blood volume, and injections of anemic and normal plasma likewise do not affect this volume at an interval of 24 hours after the last injection. 


\section{THE CORRELATION OF THE EFFECTS OF SALINE AND NORMAL PLASMA ON $\mathrm{Fe}^{59}$ UPTAKE}

Several investigators ${ }^{3,5}$ have reported that normal plasma has no stimulating effect on erythropoiesis. For this reason, a comparison was made between the effects of injections of normal plasma and saline in order to confirm these observations and to learn whether saline could be substituted for normal plasma as a control in our subsequent experiments.

Kats were divided into 8 groups so that normal plasma and saline could be compared under various experimental conditions. The results of the comparison are summarized in Table 2 .

No significant difference was found between the effects of saline and normal plasma under the variety of conditions examined. Therefore, saline was substituted for normal plasma as the control in the experiments described below.

Table 2

A COMPARISON OF THE EFFECT OF INJECTIONS OF SALINE AND NORMAL RAT PLASMA ON ERYTHROPOIESIS IN RATS

\begin{tabular}{l|c|c|c|c}
\hline \multicolumn{1}{c|}{ Experiment } & 1 & 2 & 3 & 4 \\
\hline $\begin{array}{l}\text { Number of rats in each } \\
\text { group }\end{array}$ & 4 & 5 & 7 & 7 \\
$\begin{array}{l}\text { Number and volume of in- } \\
\text { jections }\end{array}$ & $3 \times 3 \mathrm{ml}$. & $2 \times 4.0 \mathrm{ml}$. & $4 \times 4.6 \mathrm{ml}$. & $3 \times 4 \mathrm{ml}$. \\
$\gamma \quad$ of Fe injected & 114 & 110 & 38 & 34 \\
$\begin{array}{l}\text { Interval of samples after } \\
\text { Fe }\end{array}$ & $22 \mathrm{hr}$. & $19 \mathrm{hr}$. & $18 \mathrm{hr}$. & $18 \mathrm{hr}$. \\
\hline \multicolumn{4}{|c|}{ Average $\%$ uptake of Fe } \\
\hline $\begin{array}{l}\text { Normal plasma recipients } \\
\text { Saline recipients }\end{array}$ & 12.5 & 13.3 & 21.2 & 25.0 \\
\hline
\end{tabular}

THE EFFECT OF FREQUENCY OF INJECTION. AND OF VARIOUS VOLUMES OF ANEMIC PLASMA

In order to quantitate the amount of anemic plasma necessary to stimulate erythropoiesis significantly, a series of experiments was performed in which (a) the number of injections of plasma was varied and (b) the volume of each injection was altered.

Erslev ${ }^{3}$ found that two injections of anemic plasma, together equivalent to about 1.6. per cent of the weight of the animal, did not elicit a reticulocyte; hematocrit, or red cell response in rabbits. He found that 4 daily injections, totaling the approximate blood volume of the animal; were needed to effect a significant rise in the number of reticulocytes. The number of injections of anemic plasma necessary to elicit a significant response 
was determined by the following experiments in which groups of rats received the same total volume of plasma but spread over different periods of time. The results are given in Table 3.

Table 3

THE EFFECTS OF NUMBER OF INJECTIONS OF ANEMIC PLASMA ON ERYTHROPOIESIS IN RATS

\begin{tabular}{c|c|c|c|c}
\hline Experiment & $\begin{array}{c}\text { Daily injections of } \\
\text { equal volume } \\
\text { (No.) }\end{array}$ & $\begin{array}{c}\text { Anemic plasma } \\
\text { (total volume) } \\
\text { (ml) }\end{array}$ & $\begin{array}{c}\text { Rats } \\
\text { (No.) }\end{array}$ & $\begin{array}{c}\text { Average uptake to } \\
\text { \% uptake in saline } \\
\text { recipients } \\
\text { (Ratio of \%) }\end{array}$ \\
\hline 1 & 2 & 12 & 4 & 1.87 \\
1 & 3 & 12 & 4 & 1.95 \\
1 & 4 & 12 & 3 & 1.56 \\
\hline 2 & 3 & 3 & & 1.58 \\
2 & 1 & 3 & 5 & 1.00 \\
\hline
\end{tabular}

The data in Table 3 demonstrate that, with 3 injections of plasma, the maximum effect is obtained.

Figure 1 summarizes the results obtained by varying the total volumes of anemic plasma given over the 3-day period. Samples were taken 19 hours after the injection of the $\mathrm{Fe}^{59}$ (100 $\gamma \mathrm{Fe}$ per milliliter). Individual values are indicated by $\mathrm{x}$, and the line connects the average values for each set. The results indicate that $2 \mathrm{ml}$ of plasma given daily for 3. days elicits the maximum effect with the greatest economy of plasma.

Although the figure illustrates the significant effect obtained with $1-\mathrm{ml}$ injections of anemic plasma (equivalent to 1.3 per cent of rat body weight) on $\mathrm{Fe}^{59}$ uptake, a better response was obtained when twice this volume was used. The response of the individual rats showed less variability with the three $2-\mathrm{ml}$ injections.

\section{DETERMINATION OF THE PROPER SAMPLING INTERVAL AND AN EVALUATION OF THE USE OF CARRIER IRON}

Using the method described previously, we attempted to ascertain the time after the injection of radioiron when the greatest difference in uptake would be found between the rat treated with anemic plasma and that treated with saline. It is advantageous to withdraw only one blood sample to demonstrate the rate of erythropoiesis. Single sampling eliminates the possible alterations that might result from previously drawn samples.

Typical $\mathrm{Fe}^{59}$ uptake curves are shown in Figure 2 . The curves indicate that the best sampling interval is approximately 20 hours after radioiron is injected. After this interval, the rate of $\mathrm{Fe}^{59}$ uptake is similar for both the saline and anemic plasma recipients. Variations in the amount of carrier iron added to the $\mathrm{Fe}^{59}$ influenced the percentage 


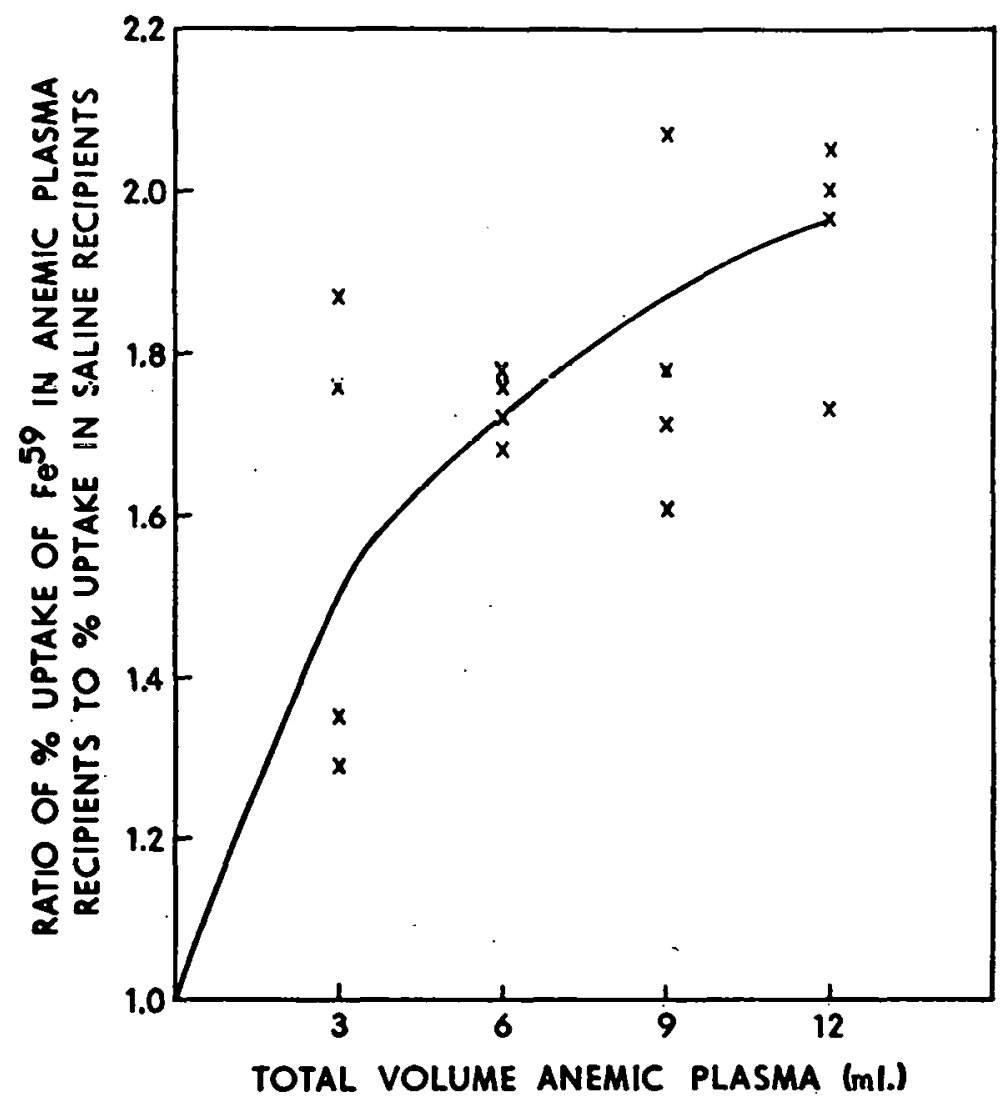

Figure 1. The effect of injections of various volumes of anemic plasma on uptake of $\mathrm{Fe}^{59}$.

uptake (Figure 2). It was practically impossible to control completely the amount of iron given to each animal in the different experiments owing to the hygroscopic property of the $\mathrm{FeCl}_{3}$ (state of carrier iron) and the inherent difficulties in the quantitative analysis of minute quantities of iron. Hence, this method as such could not be employed satisfactorily as a bio-assay procedure. In order to correct this, a series of experiments was conducted in which carrier iron was not used. This alteration in procedure enabled us to achieve approximately the same $\mathrm{Fe}^{59}$ uptake values in several experiments (Table 4).

The fact that the effect of the anemic plasma was not as great in these experiments as was demonstrated when the carrier iron was employed suggested that a sampling period other than 20 hours be tried. Thus, rats were sampled at 12,15 , or 20 hours after the injection of the radioiron. Figure 3 presents our evidence demonstrating that the sampling period at which time the ratio of $\mathrm{Fe}^{59}$ uptake by anemic plasma recipients to that by saline recipients is greatest occurred 12 hours following the injection of carrier-free $\mathrm{Fe}^{59}$. Earlier samples were not considered adequate measures of uptake because with erythropoietic inhibitors, an earlier sample may be contaminated with plasma $\mathrm{Fe}^{59}$ if the plasma clearance time is increased considerably. In addition, there is a possibility that the adminis- 


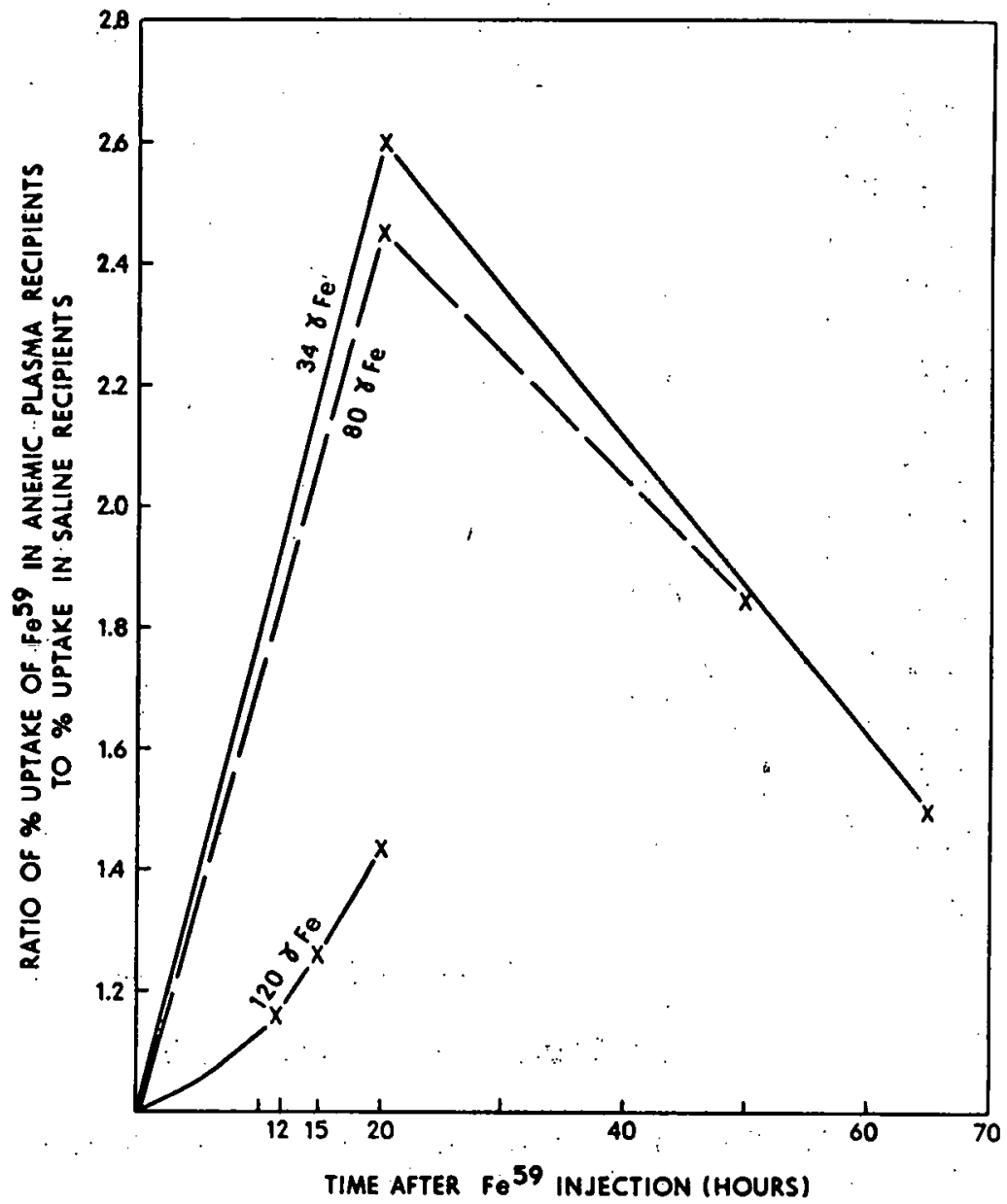

Figure 2. The effect of variations in the amount of carrier iron added to the $\mathrm{Fe}^{59}$ injection solution on the uptake of $\mathrm{Fe}^{59}$.

Table 4

UPTAKE VALUES OBTAINED IN THE ABSENCE OF CARRIER IRON

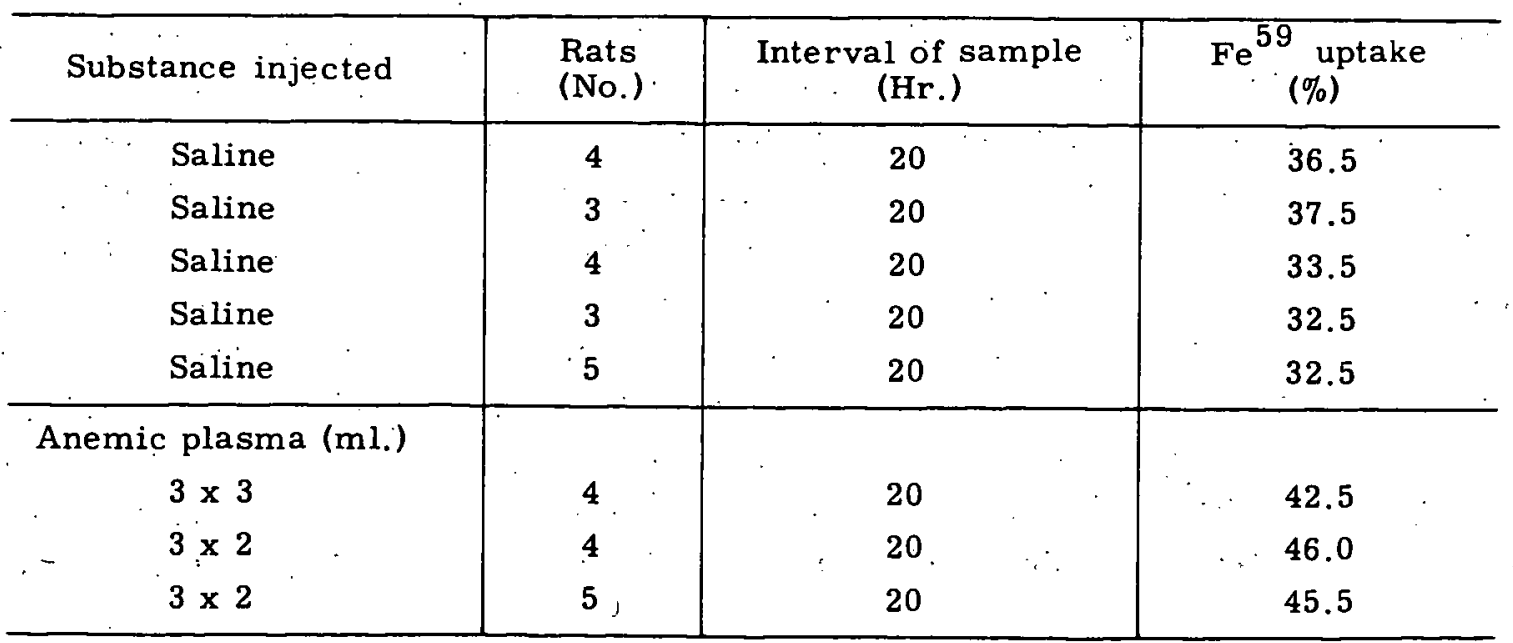


tered plasma might cause fluctuations in the blood volume during the first 12 hours after its injection.

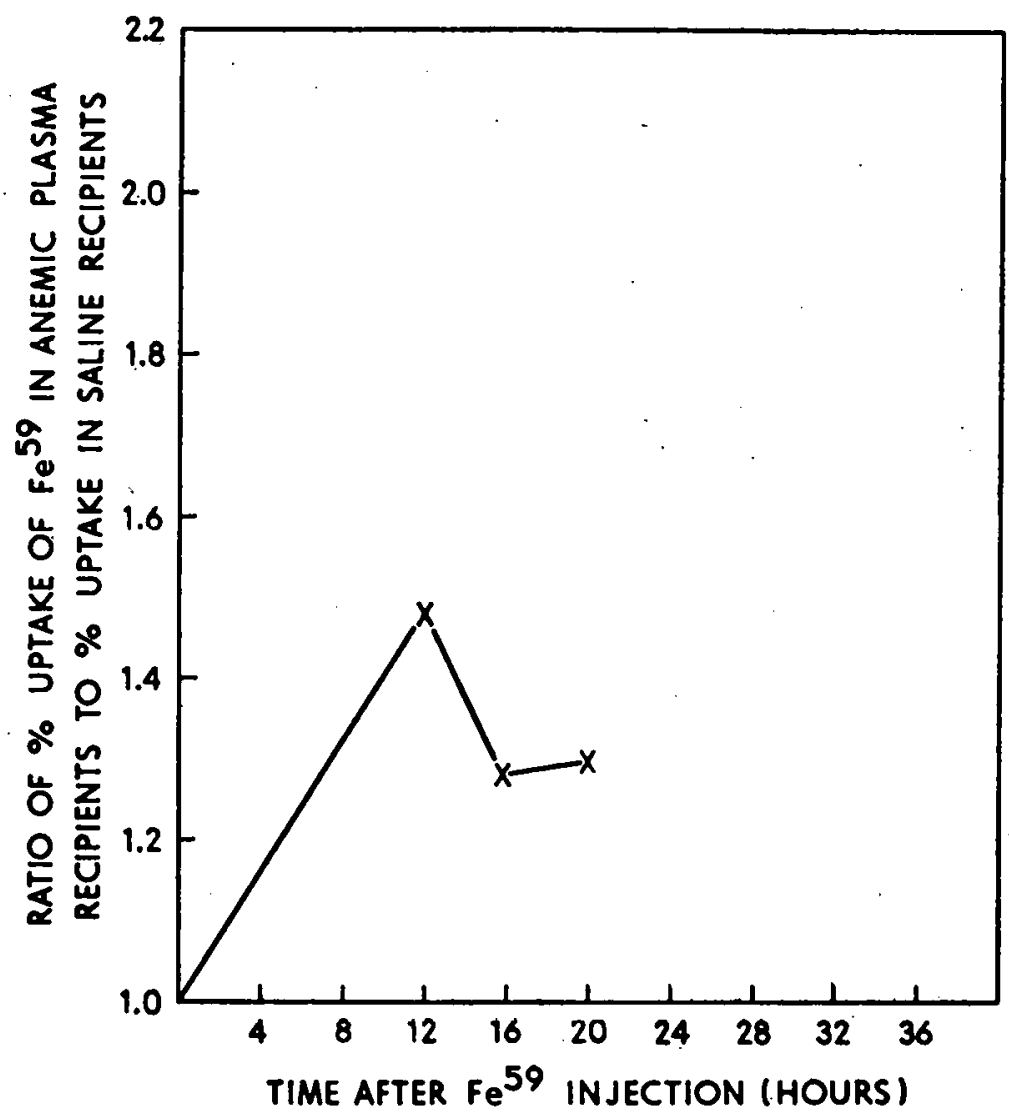

Figure 3. Ratio of $\mathrm{Fe}^{59}$ uptake by recipients of anemic plasma to that by recipients of saline.

\section{OPTIMUM TIME FOR INJECTION OF RADIOIRON}

If the injection of the $\mathrm{Fe}^{59}$ is delayed for 24 hours after the last injection of anemic plasma, a measurement of $\mathrm{Fe}^{59}$ uptake will not reveal any erythropoietic stimulation because such an effect is not measurable during this interval (Table 5). This lack of effect after one day is further indicated by the approximation of the slopes of the curves shown in Figure 4 after the 18 -hour sample. Thus, injections of $\mathrm{Fe}^{59}$ should be given within a few hours after the last injection of plasma.

\section{SUMMARY -}

Plasma from rats made anemic by bleeding contains a humoral factor that stimulates erythropoiesis in normal rats. The activity of this humoral substance has been demonstrated by an increase of the rate of incorporation of $\mathrm{Fe}^{59}$ into red blood cells following infusion of anemic plasma. An amount of anemic plasma equal to about one-half the rat's 


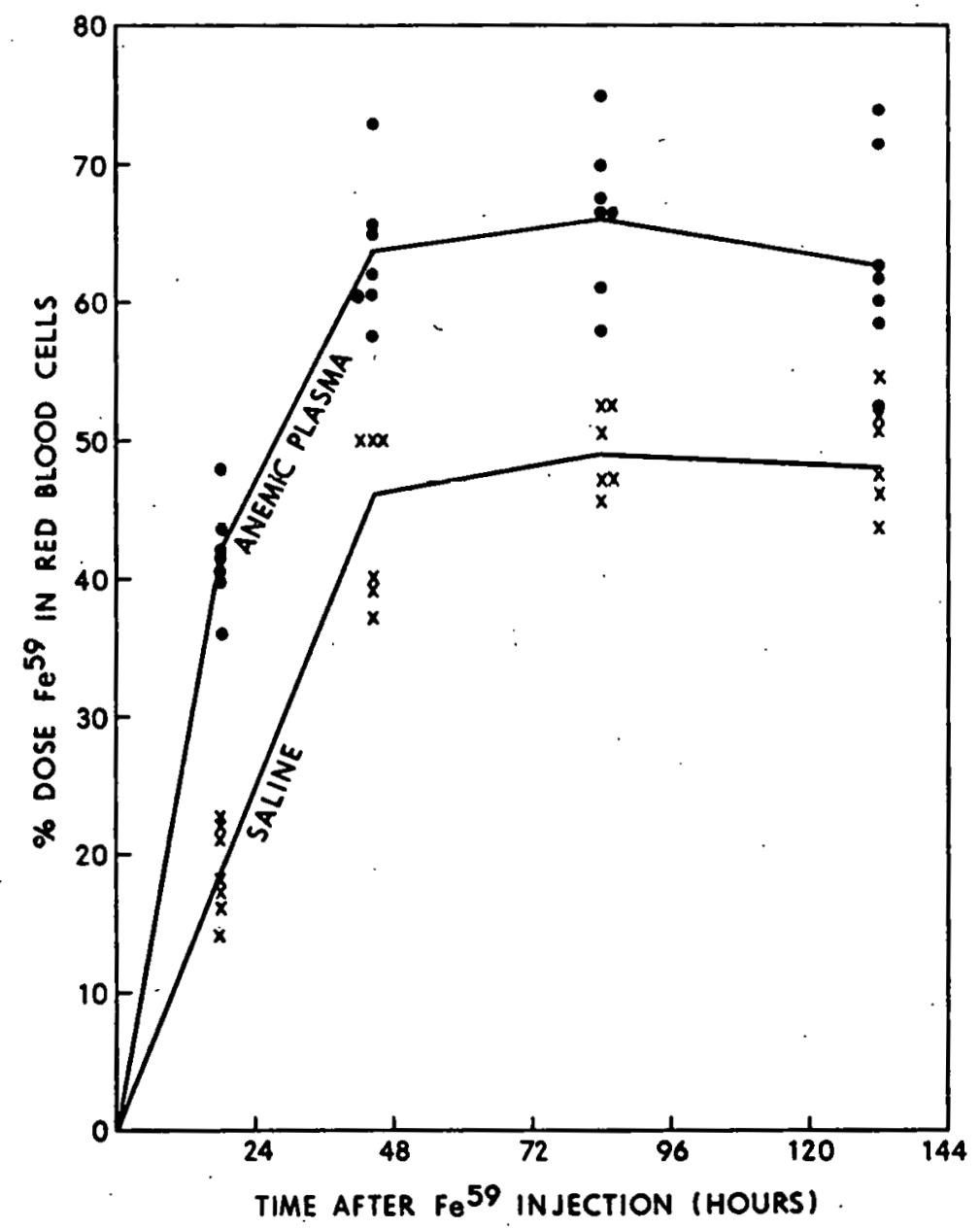

Figure 4. Effect of length of time between last plasma injection and $\mathrm{Fe}^{59}$ injection on uptake of $\mathrm{Fe}^{59}$.

Table 5

UPTAKE OF $\mathrm{Fe}^{59}$ INJECTED 24 HOURS AFTER LAST INJECTION OF SALINE OR ANEMIC PLASMA

\begin{tabular}{c|c|c|c}
\hline Substance injected & $\begin{array}{c}\text { Rats } \\
\text { (No.) }\end{array}$ & $\begin{array}{c}\text { Time after plasma } \\
\text { injection before Fe } \\
\text { injection (Hr.) }\end{array}$ & $\begin{array}{c}\text { Fe } 59 \text { uptake at 24 } \\
\text { hours (\%) }\end{array}$ \\
\hline Saline & 7 & 24 & 41.6 \\
Anemic plasma & 11 & .24 & 40.2 \\
\hline
\end{tabular}

blood volume is required to cause the stimulation. Best results were obtained with 3 doses of $2 \mathrm{ml}$ each. The $\mathrm{Fe}^{59}$ solution must be injected within a few hours after the final infusion of anemic plasma, and blood samples should be obtained 12 hours afterward. 


\section{ACKNOWLEDGMENT}

We wish to acknowledge the co-operation of Dr. Eugene Goldwasser.

\section{LITERATURE CITED}

1. Carnot, P. and C. Deflandre. Compt. rend. Acad. sc., 143:384, 1906.

2. Grant, W. C. and W. S. Root. Physiol. Rev., 32:449, 1952.

3. Erslev, A. Bluud, 8:349, 1953.

4. Gordon, A. S., S. J. Piliero, W. Kleinberg, and H. H. Freedman. Proc. Soc. Exp. Biol. Med., 86:255, 1954 .

5. Hodgson, G. and J. Toha. Blood, 9:299, 1954.

6. Toha, J. and G. Hodgson. 'Proc. Fourth Internat. Soc. Hematology, N. Y., 1952, Grune and Stratton, Inc.,. p. 58.

7. Barkan, G. and B. S. Walker. J. Biol. Chem., 135:37, 1940.

8. Hahn, P. F., W. F. Bale, J. F. Ross, R. A. Hettig, and G. H. Whipple. Science, 92:131, 1940 .

9. Walsh, R. J., E. D. Thomas, S. K. Chow, R. G. Fluharty, and C. A. Finch. Science, $110: 396,1949$.

10. Huff, R. L., W. F. Bethard, J. F. Garcia, B. M. Roberts, L. O. Jacobson, and J. H. Lawrence. J. Lab. Clin. Med., 36:40, 1950.

11. Gray, S. and K. Sterling. J. Clin. Invest., 29:1604, 1950. 


\section{STUDIES ON ERYTHROPOIESIS. II. ASSAY OF ERYTHROPOIETIN IN HYPOPHYSECTOMIZED RATS*}

\section{By}

W. Fried, L. Plzak, L. O. Jacobson, and E. Goldwasser

Experimental evidence supporting the theory that a humoral factor in the blood plasma mediates red cell production has been reviewed by several investigators. ${ }^{1,2}$ This factor, which has been referred to as erythropoietin by Bonsdorff and Jalavisto ${ }^{3}$ and others, ${ }^{4}$ has not been isolated nor is it known whether it is a single substance or several. The method utilized to determine the presence of erythropoietin in the plasma of anemic animals has been confined largely to evidence of increased erythrocyte production in normal animals that have received injections of plasma from animals made anemic by repeated phlebotomy or injections of phenylhydrazine. The hematologic technics for determining increased red cell production consist largely of reticulocyte and red cell counts, hemoglobin or hematocrit determinations on the peripheral blood, and histologic study of erythroblas tic.activity of the blood-forming tissue. As previously reported, ${ }^{5,6} \mathrm{Fe}^{59}$ uptake in newlyformed red cells is probably the most reliable single method for studying the effect of anemic plasma on erythropoiesis. Under ideal experimental conditions, the findings obtained by all these methods correlate well with one another, but an amount of plasma equivalent to one-half the blood volume is necessary to elicit a response. A sensitive method of assaying plasma from normal or anemic subjects is described in this communication.

\section{MATERIALS AND METHODS}

Preparation of animals. Young adult male Sprague-Dawley rats, approximately 3 months of age and ranging in weight from 175 to $200 \mathrm{~g}$, were used throughout these experiments. Rats, ${ }^{\dagger}$ hypophysectomized by a standard technic, were delivered to us on the day following the operation or at later intervals thereafter. They were maintained on a diet consisting of milk, fresh vegetables, and Rockland mouse diet ad libitum. The control animals were of the same sex, age, and weight.

Preparation of plasma. Rats were bled daily for 3 days by cardiac puncture until their hematocrit was reduced to $25 \%$ or less. On the fourth day, the animals were anesthefized lightly with ether, and as much blood as possible was withdrawn by cardiac puncture. To this blood was added sufficient heparin to prevent clotting (circa 20 units per cc of blood).

\footnotetext{
* Reprinted from Proceedings of the Society for Experimental Biology and Medicine, 92:203-7, 1956 .

+ Obtained from Hormone Assay Laboratories, Chicago, Illinois.
} 
The blood was immediately centrifuged at $3000 \mathrm{rpm}$. The plasma was separated, pooled with other plasma drawn at the same time, and stored at $-10^{\circ} \mathrm{C}$. This routine was followed for preparation of the plasma that we shall hereafter refer to as "anemic plasma." Plasma, which was prepared from the blood of normal, previously unbled rats, served as the control.

Test of plasma for erythropoietin. The hypophysectomized and normal rats were weighed just prior to and at the conclusion of each experiment. The plasma to be tested was administered intravenously to each animal in 2-cc doses on 3 consecutive days. Two hours following the last injection of plasma, $1 \mathrm{cc}$ of $\mathrm{Fe}^{59}$ citrate solution, diluted with normal saline to contain 2 to $3 \mu \mathrm{c}$ of radioactive $\mathrm{Fe}^{59}$, was introduced into the tail vein. Sixteen hours following injection of $\mathrm{Fe}^{59}$, a $1-\mathrm{cc}$ sample of blood was withdrawn from each rat by cardiac puncture. The radioactivity in this sample was measured in a Nancy Wood well-type scintillation counter. The radioactivity in an aliquot of the original $\mathrm{Fe}^{59}$ solution given each animal was similarly measured. Using the blood volume of the rats (estimated to be $6 \%$ of body weight, verified by $\mathrm{Cr}^{51}$ blood volume determinations after the method of Gray and Sterling), ${ }^{7}$ the amount of radioactivity injected into the rats, and the radioactivity in the 16 -hour sample, it is possible to calculate the per cent of the injected dose of $\mathrm{Fe}^{59}$ appearing in the peripheral blood cells at this time interval. In each experiment, the per cent of $\mathrm{Fe}^{59}$ taken up in a control group of rats ( 5 animals per group) was compared with the uptake in groups of rats receiving anemic plasma or normal plasma.

\section{RESULTS}

Effect of anemic plasma on uptake of $\mathrm{Fe}^{59}$ in hypophysectomized animals. . Our first experiments were conducted on rats that were hypophysectomized 10 to 13 days prior to the injection of plasma. The uptake of $\mathrm{Fe}^{59}$ in hypophysectomized animals that were given daily injections of $2 \mathrm{cc}$ each of normal plasma for 3 successive days was $5 \%$ or less; while in the hypophysectomized animals that were given anemic plasma, the uptake was $16 \%$ or more (Table 1). The uptake of $\mathrm{Fe}^{59}$ in normal rats following the injection of normal or anemic plasma according to the same regimen averaged respectively $37 \pm 4 \%$ and $48 \pm 4 \%$. The data given below are from experiments in which hypophysectomized animals were used as recipients.

Effect of interval post-hypophysectomy on sensitivity to anemic plasma. A series of experiments was undertaken to determine at what time after hypophysectomy the animal is most sensitive to anemic plasma. Normal or anemic plasma was given to rats at various periods after hypophysectomy, and the rate of erythropoiesis was observed. The results are summarized in Table 2 . An appreciable reduction in $\mathrm{Fe}^{59}$ uptake occurred by 4 days after hypophysectomy and reached a minimum by 8 days. We found it advisable, therefore, to wait at least 8 days after surgery before using the animals for assay purposes.

International Centrifuge, size 1. 
Table 1

EFFECT OF ANEMIC PLASMA ON RATE OF ERYTHROPOIESIS IN THE HYPOPHYSECTOMIZED RAT; 6 EXPERIMENTS*

\begin{tabular}{c|c|c|c|c}
\hline \multirow{2}{*}{$\begin{array}{c}\text { No. rats } \\
\text { per group }\end{array}$} & $\begin{array}{c}\text { Anemic } \\
\text { plasma }\end{array}$ & $\begin{array}{c}\text { Normal } \\
\text { plasma }\end{array}$ & Saline & No inj. \\
\cline { 2 - 5 } & 27.4 & 3.2 & 5.0 & 4.0 \\
5 & 16.3 & 3.3 & & \\
4 & 17.1 & 5.0 & 3.8 & \\
5 & 18 & 2.7 & & \\
3 & 19.3 & 5.0 & & \\
3 & 21.8 & 5.0 & & \\
\hline
\end{tabular}

Table 2

EFFECT OF THE INTERVAL AFTER HYPOPHYSECTOMY ON APPARENT SENSITIVITY OF RAT TO ANEMIC PLASMA

\begin{tabular}{c|c|c|c|c}
\hline \multirow{2}{*}{$\begin{array}{c}\text { Plasma } \\
\text { inj. }\end{array}$} & $\begin{array}{c}\text { Prior to } \\
\text { hyp. }\end{array}$ & $\begin{array}{c}4 \text { days } \\
\text { post-hyp. }\end{array}$ & $\begin{array}{c}8 \text { days } \\
\text { post-hyp. }\end{array}$ & $\begin{array}{c}13 \text { days } \\
\text { post-hyp. }\end{array}$ \\
\cline { 2 - 5 } & 37.5 & 9.1 & 4.0 & 5.0 \\
Normal & 44.6 & 18.5 & 18.1 & 18.0 \\
Anemic & \multicolumn{4}{|c}{ thyp. $=$ hypophysectomy. $^{\text {* }}$ 16-hr. sample. }
\end{tabular}

16-hr sample. $\quad t_{\text {hyp. }}=$ hypophysectomy.

- Effect of various amounts of anemic plasma on the uptake of $\mathrm{Fe}^{59}$. Because of the greater sensitivity noted in the hypophysectomized rat, it was thought desirable to investigate the possibility of using a single injection of plasma, testing its efficacy when administered at various intervals prior to the injection of $\mathrm{Fe}^{59}$. The data in Table 3 indicate that the erythropoietic effect induced by a single 2-ml injection of anemic plasma, given 4 hours prior to the $\mathrm{Fe}^{59}$, is not manifest in the 16 -hour sample, but is clearly seen when administered 24 hours prior to the administration of $\mathrm{Fe}^{59}$. The stimulus is still detected 2 or 3 days after administration of plasma. These points were further substantiated by the observations that 2 doses of $2 \mathrm{cc}$ each given 4 hours and 24 hours prior to $\mathrm{Fe}^{59}$ injection produced no greater effect on $\mathrm{Fe}^{59}$ uptake than did one injection given 24 hours previous ly. However, 2 injections, given 24 hours and 48 hours before $\mathrm{Fe}^{59}$, gave a greater response. On the basis of these results, we elected to use 2 injections of 2 cc each in future assays unless otherwise noted. 
Table 3

RELATIONSHIP OF INTERVAL BETWEEN SINGLE 2-mi INJECTION OF ANEMIC PLASMA AND ADMINISTRATION OF $\mathrm{Fe}^{59}$ TO ELICITATION OF THE ERYTHROPOIETIC STIMULUS; 5 EXPERIMENTS

\begin{tabular}{|c|c|c|c|c|}
\hline \multicolumn{5}{|c|}{$\begin{array}{l}\text { Avg } \% \text { uptake of } \mathrm{Fe}^{59} \text { in } \mathrm{RBC} \text { of } \\
\text { hypophysectomized rats }\end{array}$} \\
\hline \multirow[b]{2}{*}{$\begin{array}{l}\text { Rats } \\
\text { (No:) }\end{array}$} & \multicolumn{3}{|c|}{ Plásma given } & \multirow[b]{2}{*}{$\begin{array}{l}\text { Normal } \\
\text { plasma }\end{array}$} \\
\hline & $\begin{array}{c}4 \mathrm{hr} \text { prior } \\
\text { to } \mathrm{Fe}^{59}\end{array}$ & $\begin{array}{l}24 \mathrm{hr} \text { prior } \\
\text { to } \mathrm{Fe}\end{array}$ & $\begin{array}{l}48 \text { hr prior } \\
\text { to } \mathrm{Fe} 59\end{array}$ & \\
\hline 4 & & 12.1 & & 5.0 \\
\hline 5 & & 11.3 & 16.8 & 6.4 \\
\hline 4 & & 18.5 & 18.0 & 4.6 \\
\hline 3 & & 12.0 & 12.0 & \\
\hline 10 & 4.5 & & 15.5 & 4.0 \\
\hline
\end{tabular}

Production of anemic plasma factor by the hypophysectomized animal. Hypophysectomized animals were bled on 3 successive days until their hematocrit was $25 \%$ or less. Anemic plasma was obtained from these animals by the method that is described above. This anemic plasma, collected from hypophysectomized animals and injected into hypophysectomized animals, produced a significant increase in the uptake of $\mathrm{Fe}^{59}$ (Table 4). In other experiments it was found that plasma from normal animals subjected to splenectomy, adrenalectomy, thyroidectomy, gonadectomy, or combinations thereof and then bled increased the uptake of $\mathrm{Fe}^{59}$ in the hypophysectomized assay animal as well as did

Table 4

EFFECT OF HYPOPHYSECTOMY ON CAPACITY OF ANIMAL TO ELABORATE THE ANEMIC PLASMA FACTOR

\begin{tabular}{|c|c|c|c|c|c|}
\hline \multirow[b]{3}{*}{$\begin{array}{l}\text { Rats } \\
\text { (No.) }\end{array}$} & \multicolumn{4}{|c|}{$\begin{array}{l}\text { Avg } \% \text { uptake of } \mathrm{Fe}^{59} \text { in } \mathrm{RBC} \text { of hypophysectomized } \\
\text { rats after administration of various plasmas }\end{array}$} & \\
\hline & \multirow[b]{2}{*}{$\begin{array}{l}\text { Total vol } \\
\text { of plasma, } \\
2 \text { cc/inj. }\end{array}$} & \multicolumn{4}{|c|}{ Source of plasma } \\
\hline & & $\begin{array}{c}\text { Unoperated, } \\
\text { unbled } \\
\text { animal }\end{array}$ & $\begin{array}{l}\text { Hypophy- } \\
\text { sectomized, } \\
\text { unbled } \\
\text { animal }\end{array}$ & $\begin{array}{l}\text { Unoperated, } \\
\text { anemic } \\
\text { animal }\end{array}$ & $\begin{array}{c}\text { Hypophy- } \\
\text { sectomized, } \\
\text { anemic } \\
\text { animal }\end{array}$ \\
\hline 5 & 4 & 2.7 & 5.9 & 14.8 & 12.0 \\
\hline 5 & 4 & 5.0 & 5.8 & 16.7 & 16.3 \\
\hline 5 & 2 & & & 11.2 & 14.2 \\
\hline 13 & 2 & & & 12.4 & 12.3 \\
\hline
\end{tabular}


that from normal, bled animals.

\section{DISCUSSION}

The data show that the anemic plasma factor(s) (erythropoietin) can be assayed in the hypophysectomized recipient using the technic of $\mathrm{Fe}^{59}$ incorporation into newlyformed red cells. The mechanism of the exaggerated response to anemic plasma observed in hypophysectomized animals as compared with the response of hypophysectomized animals given normal plasma is probably a relatively simple one. Our data indicate that by 4 days after hypophysectomy, erythropoiesis is already reduced but not to the maximum reduction, which occurs at 8 to 14 days. The reduction in erythropoiesis that we have shown to occur, using $\mathrm{Fe}^{59}$ uptake by the newly-formed red cell as the criterion, has been corroborated by the finding of a reticulocyte reduction that coincides with the decreased uptake of $\mathrm{Fe}^{598}$. It seems likely that an overall reduction in the metabolic requirements of the animal occurs very soon after hypophysectomy. Several workers ${ }^{9,10}$ have shown that a new equilibrium level of red cell mass is established within 2 or 3 months after hypophysectomy. Following the operation, for example, at day 10 , the metabolic requirement of the animal is reduced but the new red cell mass equilibrium has not yet been achieved. The animal is therefore essentially comparable to an animal made polycythemic by transfusion. Consequently, red cell production falls to a minimum since a plethora of red cells already exists.

The production of erythropoietin probably also falls to a minimum under these circumstances, and, therefore, the administration of anemic plasma to the hypophysectomized animals produces an exaggerated response.

It is obvious from our data that the hypophysis is not directly concerned in the production of erythropoietin since plasma from an anemic hypophysectomized animal produces an excellent response in the hypophysectomized assay preparation. We need not enter into a discussion of whether a specific pituitary factor, as suggested by Van Dyke et al. ${ }^{10}$ and Contopoulos et.al., ${ }^{11}$ is involved directly in red cell production; but on the basis of the data reported in this paper and other data that have not yet been published, it seems likely that the effect of the pituitary on erythropoiesis is only indirect.

The great sensitivity of the hypophysectomized assay preparation to anemic plasma has made it possible for us to explore the presence of the factor(s) (erythropoietin) mediating red cell production in the plasma of normal rats and in other species with various types of anemia. These studies are being extended, and many other obvious facets of the problem, which are being investigated, will be reported at a later date.

\section{SUMMARY AND CONCLUSIONS}

Using incorporation of $\mathrm{Fe}^{59}$ into newly-formed red cells as index of red cell production, it has been shown that erythropoiesis is gradually reduced, reaching a minimum in rats at 8 to 13 days after hypophysectomy. A factor of 10 exists between incorporation of $\mathrm{Fe}^{59}$ into red cells of normal control $(37 \pm 4)$ and the hypophysectomized rat $(4 \pm 2)$ at. 
this interval. We have also found that the hypophysectomized rat is an extremely sensitive preparation for assay of factor(s) in anemic plasma that stimulates or mediates erythropoiesis. Our observations may be summarized as follows:

1. Administration of anemic plasma to hypophysectomized assay animal increases incorporation of $\mathrm{Fe}^{59} 3$ - to 7 -fold.

2. Plasma from hypophysectomized animals and unoperated controls made anemic by repeated phlebotomy increases $\mathrm{Fe}^{59}$ red cell incorporation to the same extent when administeied lu lie hypuphysectomizè assay animal.

3. A single injection of $2 \mathrm{ml}$ of anemic plasma to the hypophysectomized assay animal elicits a 2 - to 3 -fold increase in $\mathrm{Fe}^{59}$ incorporation.

The mechanism of rapid reduction of erythropoiesis that follows hypophysectomy in rats and its relationship to increased sensitivity of the hypophysectomized animal to anemic plasma are discussed briefly.

\section{LITERATURE CITED}

1. Grant, W. C. and W. S. Root. Physiol. Rev., 32:449, 1952.

2. Erslev, A. J. Blood, 10:954, 1955.

3. Bonsdorff, E. and E. Jalavisto. Acta Physiol. Scandinavica, 16:150, 1948.

4. Reisman, K. R. Blood, 5:372, 1950.

5. Plzak, L. F., W. Fried, L. O. Jacobson, and W. F. Bethard. J. Lab. Clin. Med., $46: 671,1955$.

6. Stohlman, F., Jr. and G. Brecher. Proc. Soc. Exp. Biol. Med., 91:1, 1956.

7. Gray, S. and K. Sterling. J. Clin. Invest., 29:1604, 1950.

8. Plzak, L., W. Fried, L. O. Jacobson, and E. Goldwasser, to be submitted for publication. *

9. Meyer, O., G. E. Stewart, E. W. Thewlis, and H. P. Rusch. Folia Haematol., 57:99, $-1937$.

10. Van Dyke, D. C., A. N. Contopoulos, B. S. Williams, M. E. Simpson, J. H. Lawrence, and H. M. Evans. Acta Haematologia, 11:203, 1954.

11. Contopoulos, A. N., S. Ellis, M. E. Simpson, J. H. Lawrence, and H. M. Evans. Endocrinology, 55:808, 1954 .

Paper appeared subsequently as follows: Fried, W., L. F. Plzak, L. O. Jacobson, and E. Goldwasser. Proc. Soc. Exp. Biol. Med., 94:237, 1957. 


\section{STUDIES ON ERYTHROPOIESIS. III. FACTORS CONTROLLING ERYTHROPOIETIN PRODUCTION*}

By

W. Fried, L. F. Plzak, L. O. Jacobson, and E. Goldwasser

The existence of a plasma factor, known as erythropoietin, that is capable of modifying red blood cell production is firmly established. In 1955, we ${ }^{1}$ described a bioassay for this plasma factor in the normal rat. The procedure used the incorporation of $\mathrm{Fe}{ }^{59}$ into newly-formed erythrocytes as an index of the rate of erythropoiesis. More cently, we demonstrated that the hypophysectomized $r$ at is a more sensitive assay animal than the normal one. 2,3

Further studies on the temporal relationship of hypophysectomy to changes in erythropoiesis and on erythropoietic response of the hypophysectomized animal to erythropoietin are the subjects of this paper. In addition, other sensitive assay systems that can be produced by methods designed to decrease erythropoiesis are described.

\section{MATERLALS AND METHODS}

\section{Preparation of plasma.}

On 3 consecutive days, rabbits or rats were bled by cardiac puncture, and on each of these days, the amount withdrawn approximated $2 \%$ of body weight. On alternate days thereafter, blood amounting to about $1.5 \%$ of their weight was withdrawn. After the hematocrit was reduced to $25 \%$ or less, more blood was withdrawn and heparinized, and plasma was separated and stored at $-17^{\circ} \mathrm{C}$. This procedure, which has been described in detail, ${ }^{1}$ was followed for preparation of plasma that we shall refer to as "anemic plasma." Samples from the same lot of anemic plasma were always used in comparative experiments. Plas ma, which was prepared similarly from blood of normal, previously unbled rabbits or rats served as controls.

Assay procedure.

Rats in each experimental group discussed below were given intravenously three 2-cc doses of anemic plasma on successive days. Control animals received normal plasma or saline according to the same schedule. The rate of erythropoiesis was then determined as follows: ${ }^{2} \mathrm{Fe}^{59}$ citrate $(2$ to $3 \mu \mathrm{c}$ ) was injected into the tail vein of the animal at 3-6 hours following last injection of plasma. Sixteen hours after injection of iron, a 1-cc sample of blood was taken by cardiac puncture. Activity of $\mathrm{Fe}^{59}$ in erythrocytes of the sample was determined by counting in a well-type scintillation counter. ${ }^{\dagger}$ The amount of radioactivity

\footnotetext{
* Reprinted from Proceedings of the Society for Experimental Biology and Medicine, 94:237-41, 1957.

$\dagger \quad$ Nancy Wood Counterlab, Chicago, Ill., Model SC-2L-42.
} 
in the entire circulating red cell mass was calculated and expressed as per cent of injected dose of $\mathrm{Fe}^{59}$ in peripheral red cells.

Preparation of recipient animals.

Hypophysectomized rats. Hypophysectomized male Sprague-Dawley rats, 4 or 8 weeks old and weighing 75-90 or 140-160 g, were maintained on diet consisting of milk, fresh vegetables, and Rockland mouse pellets ad libitum. The rats were given 3 injections of plasma, and the iron was introduced 6 hours after last injection. Polycythemia was produced in normal, 3-month-old male Sprague-Dawley rats by intraperitoneal injections of washed homologous erythrocytes suspended in saline. Ordinarily, 8 daily injections of 2 cc of red cells were sufficient to elevate the hematocrit from a normal value of about $45 \%$ to one between 70 and $75 \%$. The rats were used for assay the day following last injection of red cells. Hematocrit values remained between 70 and $75 \%$ throughout the assay so that additional red cell injections were unnecessary. At conclusion of assay procedure, blood values, determined by the radiochromium method of Gray and Sterling, ${ }^{4}$ were $6 \%$ of body weight in the polycythemic rat as compared with $5 \%$ in the normal rat.

Hyperoxic rats. Normal, 2-month-old male Sprague-Dawley rats, weighing between 150 and $200 \mathrm{~g}$, were placed in an oxygen tent into which flowed a continuous supply of oxygen, maintaining an atmosphere of $85-95 \% \mathrm{O}_{2} \cdot{ }^{+}$After 7 days, the rats were divided randomly into treatment groups of 5 animals each, and the 3-day regimen of plasma injection was initiated. The experiment was concluded on 10 th day that the rats were in the oxygen tent. During the 10-day period, the animals were out of the high $\mathrm{O}_{2}$ atmosphere only for the brief time necessary for injection.

Fasted rats. Normal, 2-month-old male Sprague-Dawley rats, weighing $175 \mathrm{~g}$, were deprived of all food, but water was supplied ad libitum. Radiochromium blood volume determinations after 5 days of starvation gave values of $5 \%$ body weight in the starved ani-; mal as compared to $5 \%$ in controls. At various intervals, as indicated below, rats in randomly-selected groups were injected with $\mathrm{Fe}^{59}$, and the percentage of radioiron incorporated into red blood cells was determined. Other groups were given anemic or normal plasma for 2 days before injection of iron. The rats were weighed at time of sampling. The fast was continued in all cases until conclusion of the assay.

Rats injected with dinitrophenol. Male Sprague-Dawley rats, weighing between 375 and $400 \mathrm{~g}$, were injected subcutaneously with $5 \mathrm{mg}$ of 2,4-dinitrophenol in a 10-ml volume at $\mathrm{pH} 8.5$ daily for 3 days. One-half of the group received daily intravenous injections of $2 \mathrm{ml}$ of anemic plasma while the other half received saline. Rats in the control group received $10 \mathrm{ml}$ of saline instead of dinitrophenol and anemic plasma or saline as test material. $\mathrm{Fe}^{59}$ was administered 2 hours after last injection, and the $\%$ uptake of iron was determined as described above. In many experiments, studies of the effects of anemic plasma on elements of peripheral blood were done on animals used either for measurements

\footnotetext{
* Obtained from Hormone Assay Laboratories, Chicago, Illinois.

+ Determined by Beckman $\mathrm{O}_{2}$ analyzer.
} 
of uptake of iron, or upon others that were used solely for hematologic investigations. These studies are presented in Paper No. IV of this series.

\section{RESULTS}

Effect of age of hypophysectomized rats upon response to anemic plasma.

The rate of decline of erythropoiesis following hypophysectomy in 4-or-8-week-old rats and the responsiveness to anemic plasma at several intervals following surgery were compared. The younger rats were also studied for a longer time to observe changes that occur during equilibration of red cell mass and red cell production. The results are summarized in Figure 1 and Table 1.

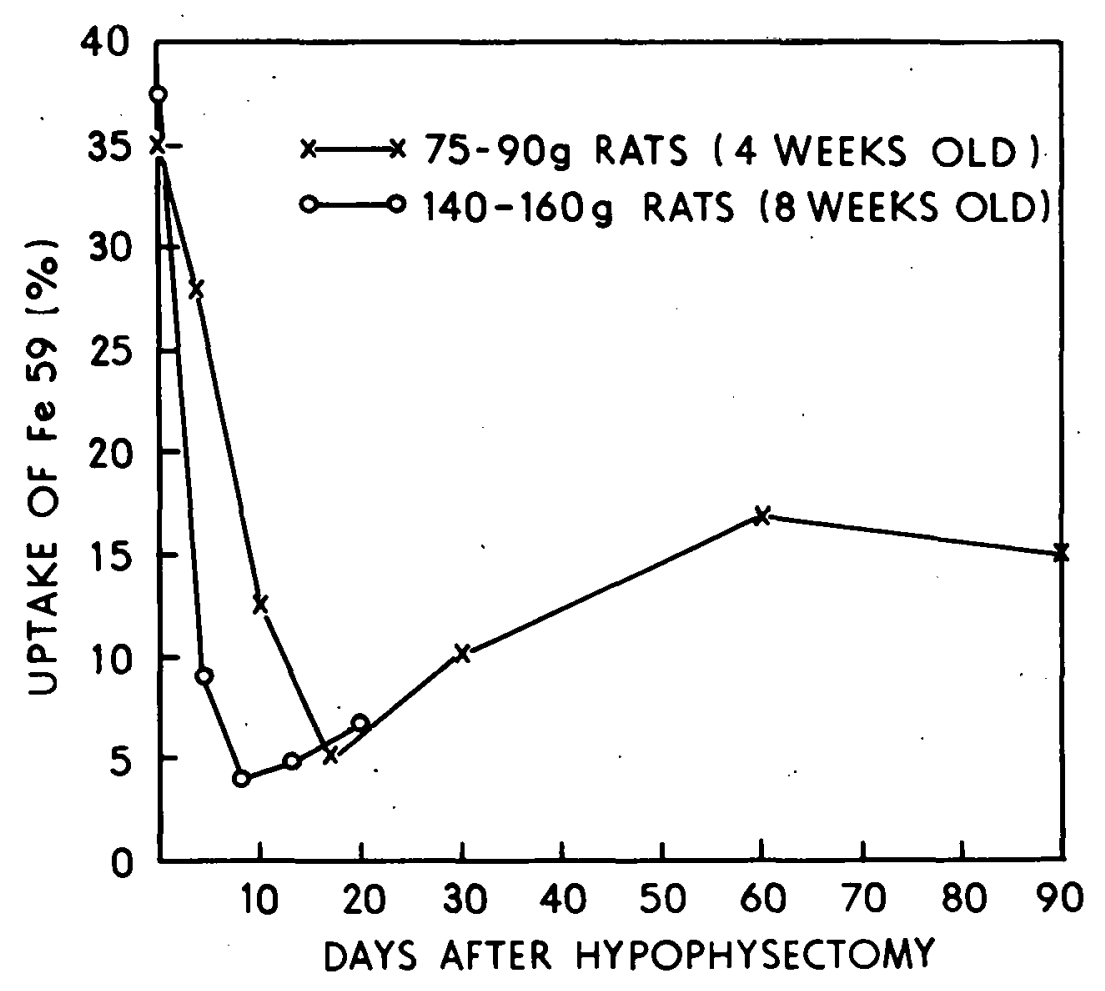

Figure 1. \% incorporation $\mathrm{Fe}^{59}$ in erythrocytes of rats hypophysectomized at 4 and 8 wk of age.

In the younger rats, values for uptake of $\mathrm{Fe}^{59}$ reached a minimum of 5 to $8 \%$ at about 17 days after hypophysectomy. In the older rats, on the other hand, the lowest rate of $\mathrm{Fe}^{59}$ uptake, 3 to $5 \%$, was reached at 8 days after removal of the pituitary (Figure 1). A comparison of responsiveness to anemic plasma of the 2 age groups is presented in Table 1.

In the assay of anemic plasma 3 days following hypophysectomy, in the younger rat the ratio of treated to control iron uptake was 1.2 , while in animals used for assay 16 days after operation, the ratio was 2.0. As would be expected, the relative response to anemic plasma was greater at the time when rate of erythropoiesis was minimal. When the anemic 
Table 1

EFFECT OF ANEMIC PLASMA ON UPTAKE OF Fe ${ }^{59}$ IN 4-WK-OLD AND 8-WK-OLD RATS AT INTERVALS OF 3, 10, 15, 16, AND 90 DAYS AFTER HYPOPHYSECTOMY

\begin{tabular}{|c|c|c|c|c|c|c|c|}
\hline \multirow{2}{*}{$\begin{array}{c}\text { Age at opera- } \\
\text { tion } \\
\text { (wcelsa) }\end{array}$} & \multirow{2}{*}{ Substance } & \multirow{2}{*}{$\begin{array}{l}\text { Unoperated } \\
\text { control }\end{array}$} & \multicolumn{5}{|c|}{$\begin{array}{c}\text { Days post-hypophysectomy } \\
\text { when } \mathrm{Fe}^{59} \text { was inj. }\end{array}$} \\
\hline & & & 3 & 10 & 15 & 16 & บ் \\
\hline \multirow[t]{2}{*}{4} & Anemic plasma & $45^{+}$ & 35 & & & .16 & 24 \\
\hline & Control & 38 & 30 & & & 8 & 15 \\
\hline \multirow[t]{2}{*}{8} & Anemic plasma & 44.6 & 17.0 & 18.1 & 18 & & \\
\hline & Control & 37.5 & 10.1 & .4 .0 & 5 & & \\
\hline
\end{tabular}

\footnotetext{
* Each interval represents average for 5 rats/group.
}

${ }^{+}$These figures represent $\%$ incorporation of $\mathrm{Fe}^{59}$.

plasma was assayed in older group of rats, the ratios at 3,10 , and 15 days were respectively 1.7, 4.5, and 3.6. These values indicate that in rats of this age, the maximum responsiveness to erythropoietin also occurred at the time of minimum erythropoietic activity, although this was several days earlier than in the case of the 4-week-old animals.

For assay purposes, we use rats that are hypophysectomized when they are 8 weeks old because the minimum rate of erythropoiesis is reached earlier and there is less variability in response than in rats that are subjected to surgery at an earlier age.

Variability of assay using hypophysectomized animals as recipients.

To give an indication of variability inherent in the assay procedure described.in this and the previous paper, ${ }^{2}$ we have compiled values for uptake of $\mathrm{Fe}^{59}$ for each control hypophysectomized animal ( 8 weeks old) used in 45 previous experiments. "Control animals" consist of all rats injected with normal plasma or saline or that were uninjected. The se controls did not differ significantly from one another. Figure 2 indicates that $74 \%$ of control hypophysectomized animals had $\mathrm{Fe}^{59}$ uptake values of $5 \%$ or less. In making a similar compilation of the $\mathrm{Fe}^{59}$ uptake values for all animals that received anemic plasma (from rabbits or rats), we found that only $0.6 \%$ had an $\mathrm{Fe}^{59}$ uptake of less than $5 \%$ and that $70 \%$ had an $\mathrm{Fe}^{59}$ uptake exceeding $10 \%$. Since Figure 2 includes animals from 45 different experiments, many different lots of anemic plasma are represented. This probably accounts for the very broad spread in results.

Polycythemic rats.

In rats with hematocrit values ranging between 70 and $75 \%$, the rate of erythropoiesis, as determined by uptake of $\mathrm{Fe}^{59}$, declined from 32 to $4 \%$. After 8 days of red cell injection, when the rate of new red cell formation was at this minimum, anemic plasma was injected for 3 days. The ratio of treated to control iron uptake values was 6.0 as compared with a ratio of 1.4 for normal rats. 


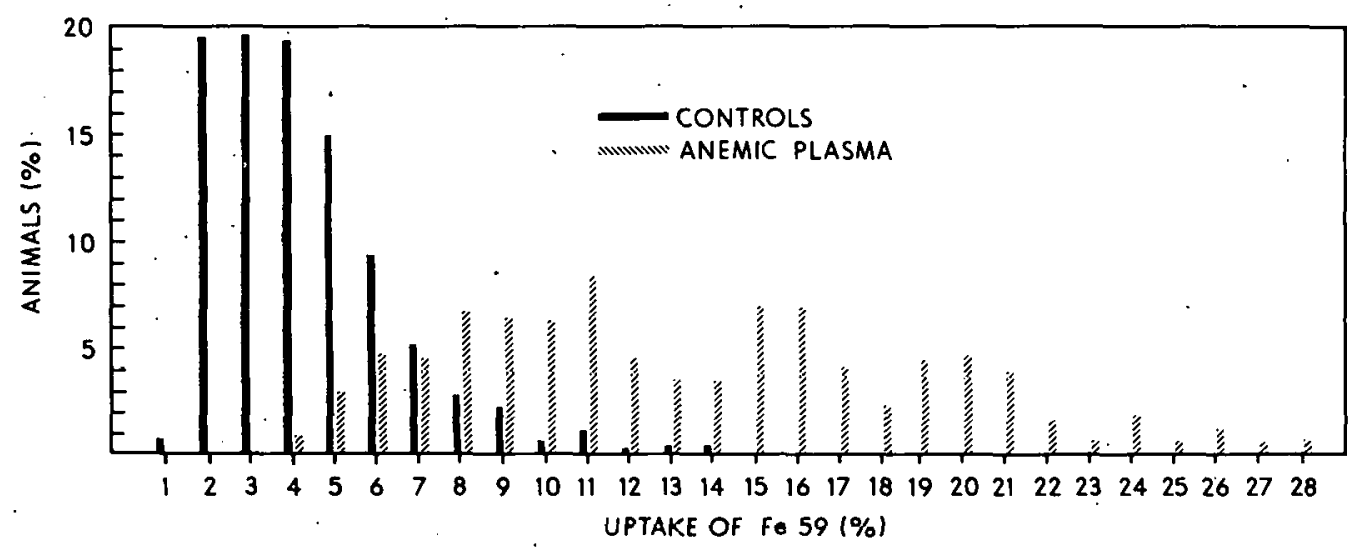

Figure 2. Distribution of $\% \mathrm{Fe}^{59}$ incorporation in control hypophysectomized rats and in those treated with anemic plasma.

\section{Hyperoxic rats.}

Rats subjected to an atmosphere of $85-95 \% \mathrm{O}_{2}$ displayed a diminished rate of erythrocyte production as evidenced by reduction in uptake of $\mathrm{Fe}^{59}$ by erythrocytes from control values of 32 to $8 \%$ at the 10 -day interval. After administration of anemic plasma to these animals, the ratio of treated to control values was 3.0 (normal rats, 1.4). Rats maintained in the atmosphere of high $\mathrm{O}_{2}$ for more than 2 weeks did not survive.

Fasted rats.

The decline in rate of erythropoiesis and increased responsiveness to anemic plasma in starved rats is illustrated in Figure 3 . When the animals lost about one-third of their body weight, their iron uptake values were at a minimum, while their response to injections of anemic plasma was high. The ratios of iron uptake values in treated over controls at $0,3,4,6$, and 7 days of fasting were respectively $1.4,4.7,5.4,3.6$, and 1.4. The sharply. diminished response in the later stage of starvation probably reflects the over-all deterioration of the animals.

Administration of dinitrophenol.

Administration of dinitrophenol to normal rats resulted in increased rate of erythropoiesis; about $70 \%$ greater than that in controls. Animals treated with dinitrophenol showed a response to anemic plasma about $12 \%$ greater than that to saline. Untreated animals had a response to anemic plasma that was about $100 \%$ greater than that to saline. A comparison of the responses to anemic plasma of these variously treated animals is given in Table 2 .

\section{DISC USSION}

In previous papers ${ }^{2,3}$ we presented data indicating that erythropoiesis as measured by incorporation of $\mathrm{Fe}^{59}$ or reticulocyte values, declines following hypophysectomy. Administration of anemic plasma to animals in which erythropoiesis is at a minimum elicits an exaggerated response in terms of new red cell formation. 


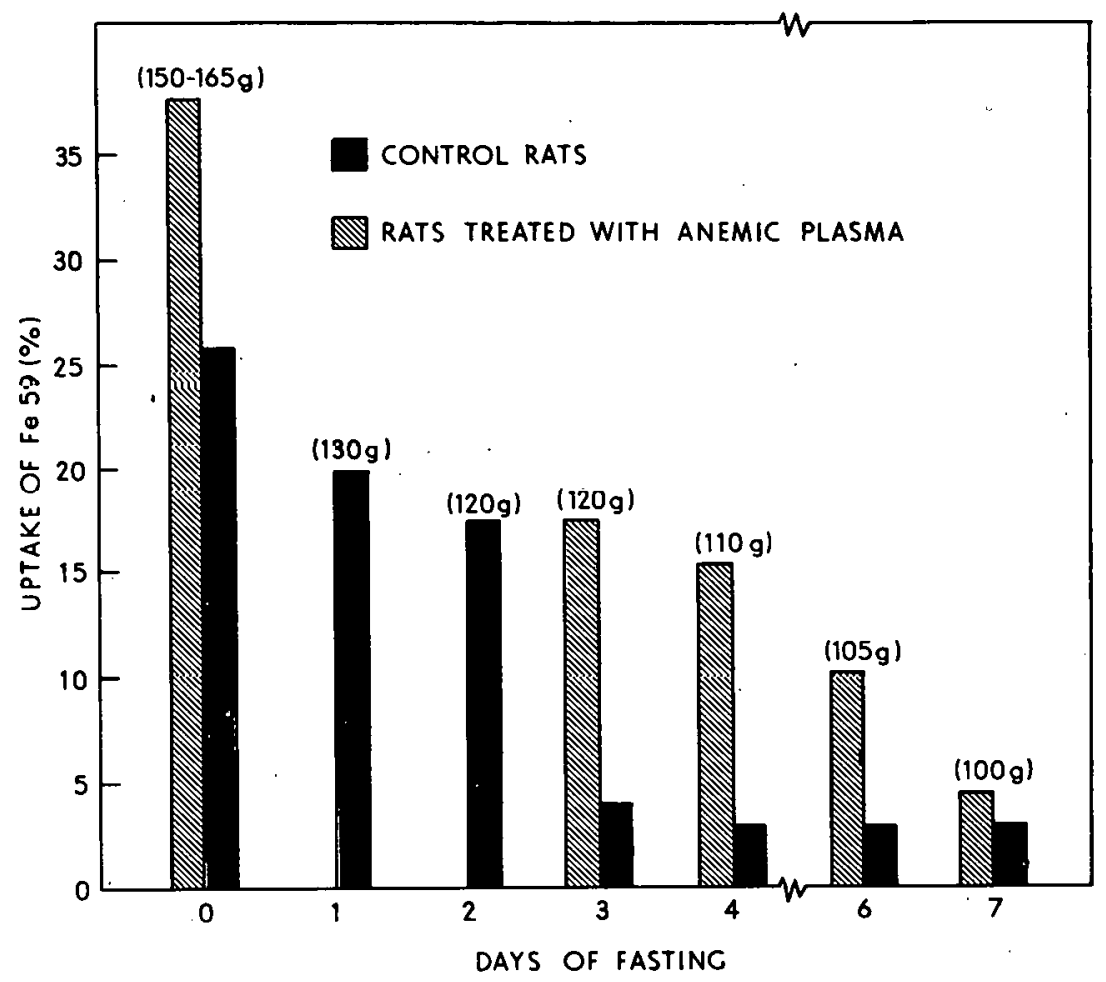

Figure 3. Effect of duration of starvation on $\mathrm{Fe}^{59}$ incorporation and on response to erythropoietin in 8 -wk-old rats.

Table 2

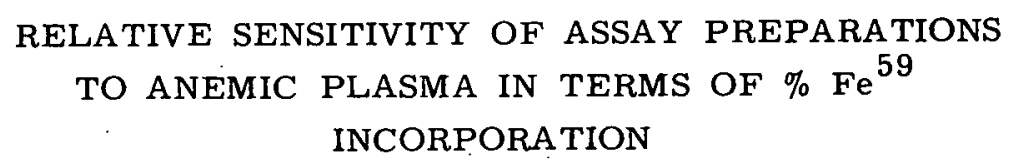

\begin{tabular}{l|c|c}
\hline \multirow{2}{*}{ Recipient * } & \multicolumn{2}{|c}{ Plasma inj. } \\
\cline { 2 - 3 } & Anemic & Control \\
\hline Polycythemic & 24 & 4 \\
Normal & 44 & 32 \\
High O2 & 24 & 8 \\
Normal & 46.5 & 34 \\
Starved (4 days prior & 15 & 3 \\
$\quad$ to Fe 59 admin.) & 38 & 27 \\
Normal . & 42 & 36 \\
DNP to normal rat & 43 & 22 \\
Normal &
\end{tabular}

${ }^{*}$ Each figure is average of 5 individual values. 
In the present paper we show that rats hypophysectomized at 4 weeks of age, undergo a decline in erythropoiesis that is considerably more gradual than that observed in rats hypophysectomized at 8 weeks of age. The reason for this difference is obscure but certainly deserves further study. The data presented here also indicate that as the new equilibrium between red cell formation and red cell mass is slowly being established, the uptake of $\mathrm{Fe}^{59}$ rises from low values found shortly after hypophysectomy to those about midway between pre-operative level and the lowest point. They remain at that level for at least 90 days (length of our observations).

The following hypothesis was suggested previously in part as an explanation of our data. ${ }^{2,3}$ After hypophysectomy, the over-all metabolic requirement of the animals drops rapidly to a level that is a fraction of that in the normal animal. There is, therefore, a decrease in the demand for oxygen by the tissues. Since the red cell mass does not decrease significantly within the first 2 or 3 weeks, therc cxists a relative plethora of erythrocytes, analogous to that in an animal with a transfusion-produced polycythemia. This discrepancy between demand of tissues for $\mathrm{O}_{2}$ and the amount of $\mathrm{O}_{2}$ available manifests itself, in some manner, by bringing about a reduction in production of erythropoietin, and as a consequence, erythropoiesis falls to a minimum within a week after hypophysectomy. At this time, administration of anemic plasma rich in erythropoietin would be expected to increase markedly the production of red cells.

Because of the radical initial reduction in erythropoiesis with continuing natural death of red cells, the red cell mass declines slowly. This gradual decrease in $\mathrm{O}_{2}$-carrying capacity. lessens the discrepancy between $\mathrm{O}_{2}$ supply and demand.

As the plethoric state that was established initially slowly diminishes, the rate of erythropoiesis that had decreased to a minimal value begins to rise until it is able to maintain the red cell mass at a level compatible with the new rate of demand for $\mathrm{O}_{2}$ by the tissues.

According to this working hypothesis, other experimental conditions that likewise produce a discrepancy between the demand for $\mathrm{O}_{2}$ and availability of $\mathrm{O}_{2}$ should also alter the rate of erythropoiesis.

In the experiments with polycythemic rats, the oxygen-carrying capacity of the blood is increased with, probably, no increase in the metabolic requirement for oxygen. This situation is therefore analogous to that in the rat shortly after hypophysectomy and also results in a decreased rate of erythropoiesis and increased responsiveness to anemic plasma.

When animals are subjected to an environment of $85-95 \% \mathrm{O}_{2}$, there are small but significant increases in the amount of oxygen that is carried. ${ }^{5,6}$ As in the case of hypophysectomized and polycythemic animals, this condition, by increasing the discrepancy between the supply and demand for $\mathrm{O}_{2}$, decreases the rate of erythropoiesis and heightens responsiveness to erythropoietin.

Animals subjected to starvation have been shown to have decreased basal metabolic rates very shortly following the onset of the fast. ${ }^{7}$ In acute starvation, a marked decrease 
in the tissue demand for oxygen exists without appreciable change in the number of circulating erythrocytes. Thus, a relative plethora of red cells exists in these animals and, like the other preparations discussed above, a decrease in erythropoiesis occurs. Acute caloric deprivation may have an appreciable effect on the synthesis of the plasma factor(s) involved in erythropoiesis. This possibility needs clarification. On the other hand, it is known that protein-deprivation in rats reduces the incorporation of $\mathrm{Fe}^{59}$ into the red cells.

While the situations discussed above all tended to increase the responsiveness of animals to erythropoietin, the rats that were treated with dinitrophenol would be expected to increase their metabolic requirement for $\mathrm{O}_{2}$ without an immediate, compensating increase in supply of $\mathrm{O}_{2}$. This is the reverse of the previous cases, and if the hypothesis stated above is valid, the rate of erythropoiesis should increase and the responsiveness to erythropoietin should decrease, as they do. Preliminary experiments with the naturally-occurring metabolic stimulant triiodothyronine gave similar results.

These investigations suggest that formation of erythropoietin and consequently the rate of erythropoiesis are regulated not by the absolute $\mathrm{O}_{2}$ tension of the blood, but rather by the relationship between $\mathrm{O}_{2}$ tension of the blood and the oxygen demand by the tissues.

\section{SUMMARY AND CONCLUSIONS}

1. We studied the erythropoietic response to anemic plasma of a variety of experimental conditions in the rat. Rats subjected to hypophysectomy, an atmosphere of high $\mathrm{O}_{2}$, starvation, and transfusion-induced polycythemia have a decreased rate of erythropoiesis and an exaggerated response to the administration of anemic plasma. 2. Treatment with dinitrophenol increases the rate of erythropoiesis and decreases the response to anemic plasma. 3. These findings are in agreement with the hypothesis that the rate of erythropoiesis is determined by the amount of erythropoietin, the production of which is regulated by the relationship between $\mathrm{O}_{2}$ supply and demand, not by either factor alone.

\section{LITERATURE CITED}

1. Plzak, L. F., W. Fried, L. O. Jacobson, and W. F. Bethard. J. Lab. Clin. Med., 46: $671,1955$.

2. Fried, W., L. F. Plzak, L. O. Jacobson, and E. Goldwasser. Proc. Soc. Exp. Biol. Med., 92:203, 1956 .

3. Jacobson, L. O., L. F. Plzak, W. Fried, and E. Goldwasser. Nature, 177:1240, 1956.

4. Gray, S. and K. Sterling. J. Clin. Invest., 29:1614, 1950.

5. Tinsley, J. C., Jr., C. Moore, R. Dubach, V. Munnuch, and M. Grinstein. Ibid., 28: $1544,1949$.

6. Campbell, J. A. J. Phys., 62:211, 1927.

7. Morgulis, S. Fasting and Undernutrition, E. P. Dutton and Co., New York 1923.

* Bethard, W. and R. W. Wissler, personal communication. Paper appeared subsequently as follows: Bethard, W. F., R. W. Wissler, J. S. Thompson, M. A. Schroeder, and M. J. Robson. Blood, 8:146, 1958 . 


\section{STUDIES ON ERYTHROPOIESIS. IV. RETICULOCYTE RESPONSE OF HYPOPHYSECTOMIZED AND POLYCYTHEMIC RODENTS TO ERYTHROPOIETIN *}

By

L. O. Jacobson, E. Goldwasser, L. F. Plzak, and W. Fried

Erythropoiesis is reduced to a minimum in hypophysectomized rats within 3 weeks after removal of the pituitary. ${ }^{1,2}$ During this same interval, there is a rapid overall reduction in metabolic requirements; ${ }^{3}$ although the red cell mass remains within normal limits. ${ }^{4}$ For this reason, we have suggested that the animal in this state is comparable to one with a transfusion-induced polycythemia and as a consequence, erythropoiesis decreases. Administration of plasma obtained from normal or hypophysectomized animals made anemic by repeated bleeding or phenylhydrazine administration produces an increase in incorporation of $\mathrm{Fe}^{59}$ into red cells of the hypophysectomized recipients. The increased incorporation is 3 or more times greater than that in control hypophysectomized animals that are given normal plasma or saline.

The effect of age at the time of hypophysectomy and the effect of transfusion-induced polycythemia upon erythropoiesis are described in this paper. In addition, the reticulocytic response of hypophysectomized rats and polycythemic mice to "anemic plasma" is also reported.

\section{MATERIALS AND METHODS}

Anemic and control plasmas were prepared according to the methods described in Part III ${ }^{5}$ of this series.

Hypophysectomized rats of 2 age groups. In one experiment, 30 Sprague-Dawley male rats, 26 to 28 days of age, were studied. The average body weight was $100 \mathrm{~g}$. Reticulocyte determinations were made on all rats the day before 20 were hypophysectomized and the other 10 sham-operated. Thereafter, reticulocyte values were obtained daily from 10 hypophysectomized and 5 sham-operated rats on alternate days. This was continued for 7 days and then at less frequent intervals. In the second experiment, conducted similarly, the rats were 2 months old with an average weight of $175 \mathrm{~g}$.

Hypophysectomized recipients of anemic plasma. Four days after hypophysectomy, Sprague-Dawley rats, each weighing about $200 \mathrm{~g}$, were divided randomly into 3 groups, of 5 animals each. Animals in group 1 received no injections (untreated controls); those in group 2, "anemic" rat plasma; and those in group 3, normal rat plasma. Two-cc doses of plasma were injected daily into the tail vein on 3 consecutive days. Reticulocytes were

* Reprinted from Proceedings of the Society for Experimental Biology and Medicine, 94:243-49, 1957. 
counted prior to the first plasma injection and daily thereafter for 6 days.

Preparation of polycythemic recipients. CF No. 1 mice weighing $23 \mathrm{~g}$, were made polycythemic by intraperitoneal injections of 75 to $80 \%$ concentration of washed homologous red cells suspended in saline. The suspension was given in $0.5-c c$ doses on successive days and once again 2 days later. Hematocrit determinations were made thereafter at frequent intervals, and red cell injections were repeated when necessary to maintain hematocrit readings of about 70 to $75 \%$. At about 6 days after the first injection, when no reticulocytes were found in the peripheral blood smear, the mice were used for the anemic plasma injection experiments.

Polycythemic recipients of anemic plasma. Forty-five polycythemic mice were divided into 3 groups of 15 mice each. Those in group 1 received anemic rat plasma; those in group 2, normal rat plasma; and those in group 3, saline. The plasma or saline was injected intravenously for 4 successive days in doses of $0.5 \mathrm{cc}$. Beginning on fifth day, injections were given every other day until the 11 th day. In a separate but otherwise identical experiment, blood volume determinations were done on the 3 groups described above as well as on 5 normal mice that received saline and on 5 normal mice that received neither saline nor plasma. In another experiment, intravenous injections of plasma or saline were begun on the same day that mice were given the first intraperitoneal injection of red cells. Plasma was given for 19 days ( 5 days/week) and the red cell suspension at intervals sufficient to produce and maintain a polycythemic condition. Three groups of 10 mice each were studied. Those in group 1 received anemic rabbit plasma; those in group 2, normal rabbit plasma; and those in group 3, saline. Reticulocyte counts were made frequently throughout the 19-day period of study. In yet another study, doses of $0.5 \mathrm{cc}$ normal or anemic rabbit plasma were given intraperitoneally at the same time that red cells were being given, by the same route, to each of $10 \mathrm{mice}$ in 2 groups. The $10 \mathrm{mice}$ in the third group received saline. Plasma injections were given for 16 days (5 days/week) and the red cells as necessary to produce and maintain a polycythemia. Hematocrit determinations and reticulocyte counts were made on $5,8,12$, and 15 days following the first plasma and red cell injections.

All hematologic studies were made on blood drawn from tail vein and were limited, for purposes of this communication only, to hematocrits and reticulocytes. Blood for hematocrit determinations was collected in heparinized capillary tubes and spun in a microhematocrit centrifuge. "Reticulocytes were counted by the direct smear method, using brilliant cresyl blue without counterstain. When no reticulocytes were found in $10 \times 10^{6}$ red cells, the values were considered to be $0.000 \%$. Blood volumes were determined according to $\mathrm{Cr}^{51}$ red cell labeling technic of Sterling and Gray. ${ }^{6}$ This was modified some what for the mice. The radioactivity of each sample was counted in a well-type.scintillation counter using $0.1 \mathrm{cc}$ of donor-tagged blood cells in $0.9 \mathrm{cc}$ of distilled water as a standard. Hematocrit determinations were made at the time that blood for blood volume determinations was collected to permit calculation of the red cell mass as well as that of plasma volume.

* International Hematocrit Centrifuge, A. S. Aloe Co., St. Louis, Missouri. 
For histologic studies, polycythemic mice were divided into 4 groups. Group 1 (control) consisted of polycythemic mice that had received neither plasma nor saline. Group 2 consisted of polycythemic mice that had received anemic rabbit plasma. Animals in group 3 had received normal rabbit plasma, and those in group 4, saline. Five mice in each group were sacrificed 8 days after the first of 6 daily intravenous injections of 0.5 cc plasma or saline. The hematocrit was maintained at about $70 \%$ throughout this experimental period. The mice were killed by cervical fracture, and samples of liver, spleen, and bone marrow (femur) were taken for examination. The tissues were fixed in ZenkerFormol, embedded in nitrocellulose, cut at $6 \mu$, and stained with hematoxylin-eosinazure.

\section{RESULTS}

Effect of age at time of hypophysectomy. The reticulocyte values of 26 - to 28 -dayold rats were about $13 \%$ on the day before hypophysectomy. During the first 5 days thereafter, the reticulocyte values of hypophysectomized and sham-operated rats were comparable. By 6 days, however, the reticulocyte values of the hypophysectomized rats were appreciably lower than those of sham-operated animals and, as indicated in Figure 1, they

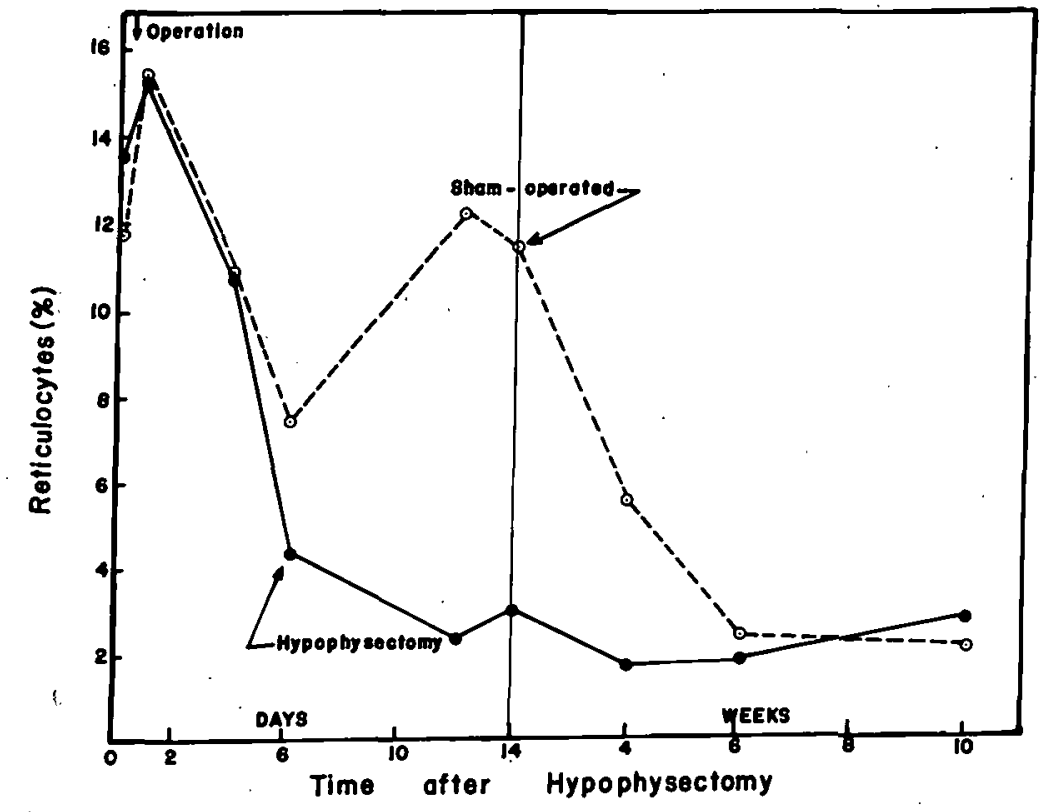

Figure 1. Effect of hypophysectomy on reticulocyte values of 26- to 28-day-old rats (avg wt, $100 \mathrm{~g}$ ).

continued to fall until the minimal value of $1.7 \%$ was reached by the 4 th post-operative week. The number of reticulocytes in sham-operated rats fell more slowly, but by 6 weeks, the values of both groups were comparable and stabilized at $2.5 \%$. Reticulocyte values of 2 -month-old rats were about $5.5 \%$ before hypophysectomy. The reticulocytes dropped from the pre-operation value to $2 \%$ at 4 days afterwards in the hypophysectomized rats and con- 
tinued to decline, reaching a minimum of $0.3 \%$ by 10 days. They remained at this level for 3 weeks, then gradually rose to $1.7 \%$ by 6 weeks. The per cent of reticulocytes in shamoperated animals very gradually declined to 2.5 by 11 days after surgery and remained essentially unchanged the reafter (Figure 2).

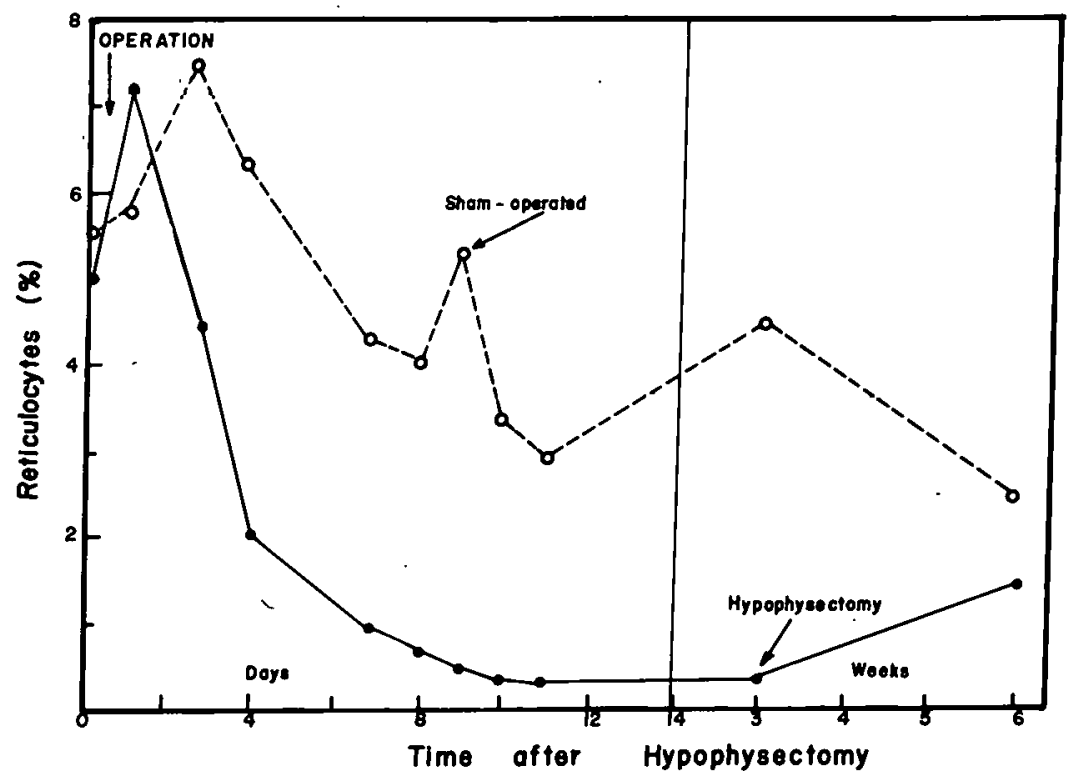

Figure 2. Effect of hypophysectomy on reticulocyte values of 52-day-old rats (avg wt, $175 \mathrm{~g}$ ).

Effect of anemic rat plasma on hypophysectomized rats. As indicated in Figure 3 , the reticulocyte values of the hypophysectomized rats injected with anemic plasma rose to $2.3 \%$ by the fourth day after the first injection. Values for normal plasma controls reached a maximum of $0.7 \%$ whereas those for untreated controls remained at the baseline (Figure 3).

Effect of anemic plasma on polycythemic mice. By 1 day following 4 daily injections of anemic rat plasma, the reticulocyte values of polycythemic mice were $0.4 \%$ as compared with $0.000 \%$ for mice that received similar injections of normal plasma or saline. By 11 days following repeated injections, the reticulocyte values of the group receiving anemic plasma were $2.3 \%$, whereas the reticulocyte values of mice receiving normal plas ma or saline were less than $0.001 \%$ (Figure 4). Simultaneous $\mathrm{Fe}^{59}$ red cell incorporation studies and reticulocyte counts were conducted in this experiment. On the day that the reticulocytes of the polycythemic anemic plasma recipients were $0.4 \%$ and the normal plas $\mathrm{ma}$ and saline recipients were $0.000 \%$, the $\mathrm{Fe}^{59}$ red cell incorporation data failed to show any significant difference between the groups. When reticulocytes reached $2.6 \%$, however, the $\mathrm{Fe}^{59}$ red cell incorporation studies showed a value more than twice that of the saline or normal plasma controls but failed to show any significant difference between the latter groups. 


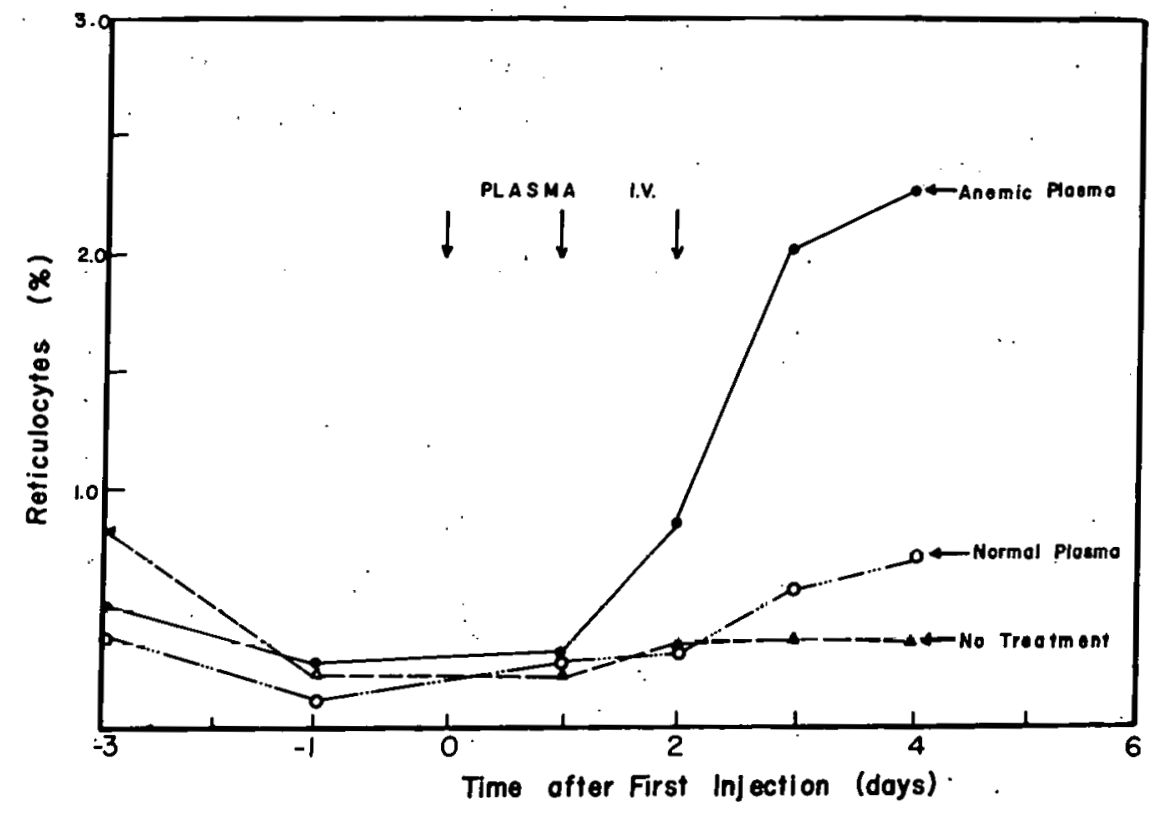

Figure 3. Effect of 2-cc intravenous injection of anemic plasma compared with that of normal rat plasma on reticulocyte values of hypophysectomized rats (avg wt, $200 \mathrm{~g}$ ). Injections were started on the 7 th day after hypophysectomy.

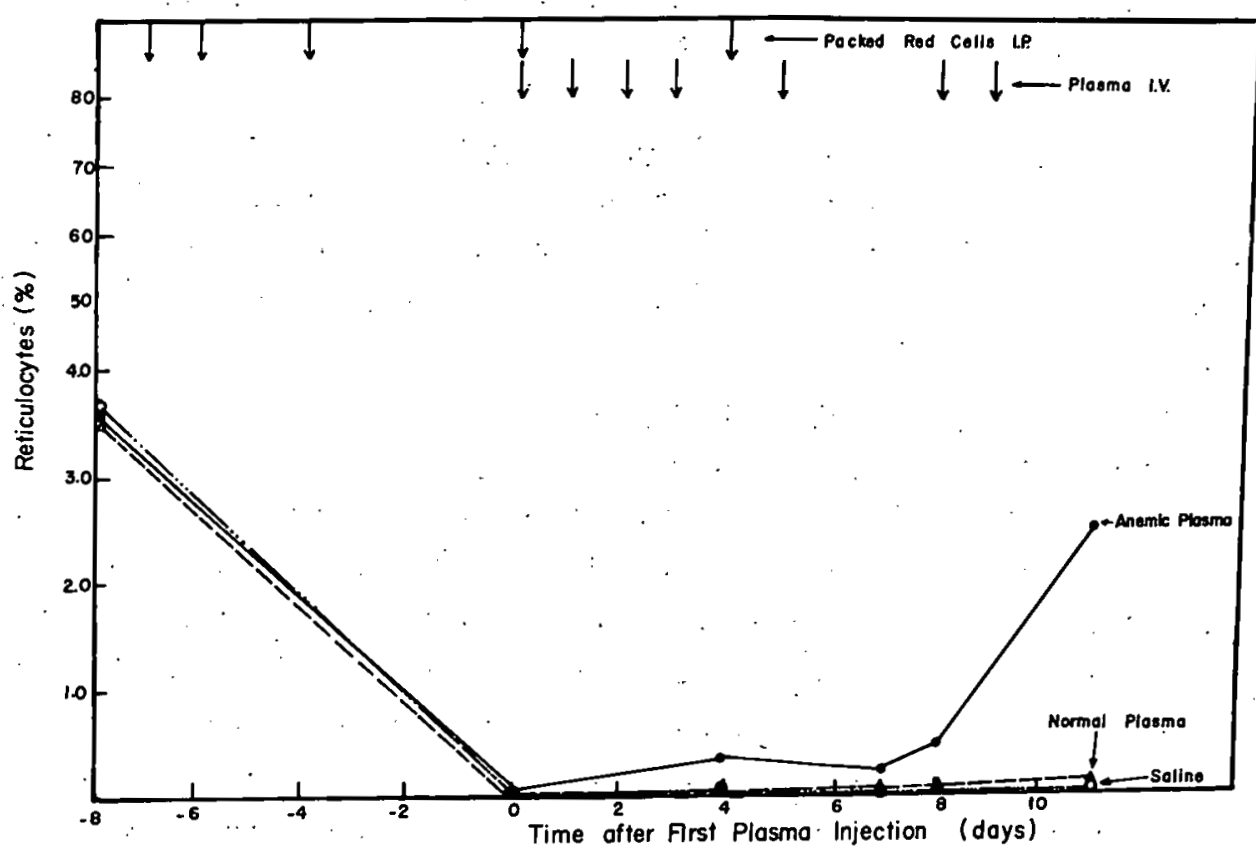

Figure 4. Effect of $70.5-\mathrm{cc}$ intravenous injections of anemic rat plasma compared with that of normal rat plasma on reticulocyte values of mice that had a transfusion-induced polycythemia. 
A definite increase in red cell mass was found in the polycythemic mice that received anemic plasma, normal plasma, or saline (Table 1). The plasma volume was decreased moderately in these polycythemic animals as compared with the untreated normal controls. As was expected, no significant difference in red cell mass was noted between the 3 polycythemic groups.

Table 1

EFFECT OF ANEMIC PLASMA ON BLOOD VOLUME OF NORMAL AND POLYCYTHEMIC CF NO. 1 MICE

\begin{tabular}{l|c|c|c|c|c|c}
\hline \multirow{2}{*}{ Treatment } & \multicolumn{2}{|c|}{} & \multicolumn{2}{|c|}{ Total blood vol } & \\
& Wt $(\mathrm{g})$ & $\begin{array}{c}\text { Hemato- } \\
\text { crit }(\%)\end{array}$ & (cc) & $\begin{array}{c}\text { \% } \\
\text { body wt. }\end{array}$ & $\begin{array}{c}\text { Red cell } \\
\text { mass (cc) }\end{array}$ & $\begin{array}{c}\text { Plasma } \\
\text { vol (cc) }\end{array}$ \\
\hline Normal & 23 & 54 & 1.46 & 6.3 & 0.79 & 0.67 \\
Normal saline & 24.6 & 55.5 & 1.59 & 6.4 & 0.88 & 0.71 \\
Polycythemic saline & 23.9 & 76.4 & 2.43 & 10.1 & 1.85 & 0.57 \\
Polycythemic normal plasma & 24.4 & 77 & 2.58 & 10.5 & 1.98 & 0.59 \\
Polycythemic anemic plasma & 24.8 & 74 & 2.23 & 9.0 & 1.65 & 0.58 \\
\hline
\end{tabular}

It is worthy of note that a total of only 4 injections of anemic plasma or normal plasma was given in this experiment and that less than $0.001 \%$ reticulocytes were observed in normal plasma- and saline-injected groups. In the other experiments described below, many more injections of anemic and normal plasma were given and a slight increase in reticulocytes above the baseline was invariably observed in the normal plasma-injected animals.

In another experiment, the reticulocyte values of the recipients were $1.3 \% 6$ days after first intravenous injection of anemic rabbit plasma and the first intraperitoneal injection of red cells, whereas these values were $0.000 \%$ in mice that received normal plasma or saline. By 10 days, when the reticulocyte values of mice that were given normal plasma or saline were still $0.000 \%$, the reticulocytes of the mice that received anemic plasma reached a peak of $3.7 \%$. No further increase in number of reticulocytes occurred in mice receiving anemic plasma, even though the injections were continued for 20 days. A slight increase in reticulocyte values (about $0.1 \%$ ), however, occurred in mice receiving normal plasma by 20 days as compared with $0.000 \%$ in mice receiving saline (Figure 5 ). Injections of anemic plasma given intraperitoneally at the same time that red cell suspensions were injected via the same route produced responses similar to those described above (Figure 6 ). By 5 days after the first injections of plasma and red cells, the reticulocyte values of mice that received anemic plasma were $1.4 \%$ as compared with $0.000 \%$ for mice that had been given normal plasma or saline. By 12 days, the reticulocyte values of anemic plasmatreated animals had risen to $2.2 \%$, while those of animals that had been given normal plas- 


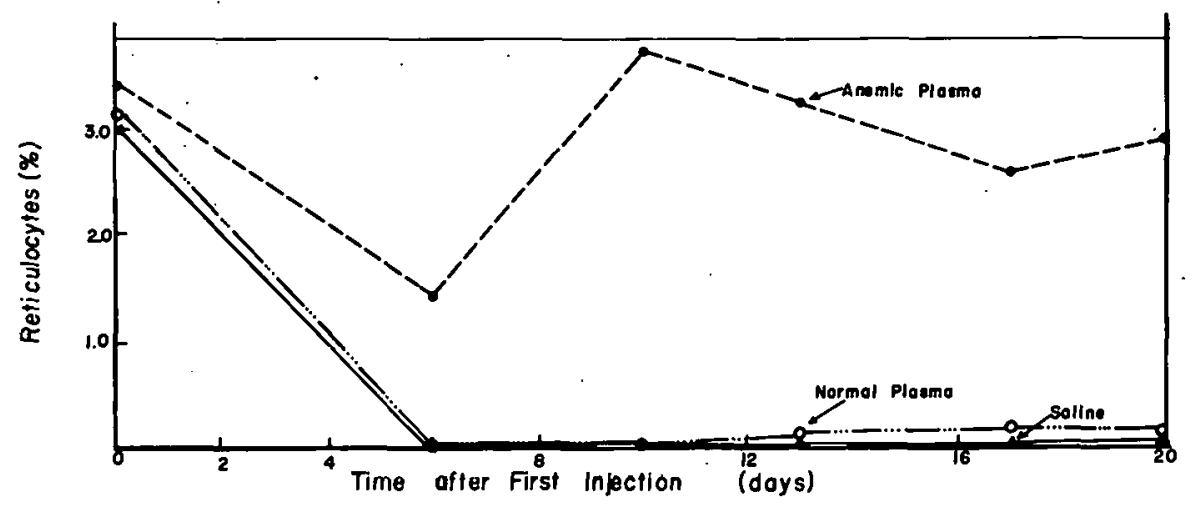

Figure 5. Effect of repeated 0.5 -cc injections of anemic and normal rabbit plasma on reticulocyte values of mice that were given first intravenous injection of plasma on same day that transfusions for polycythemia were initiated.

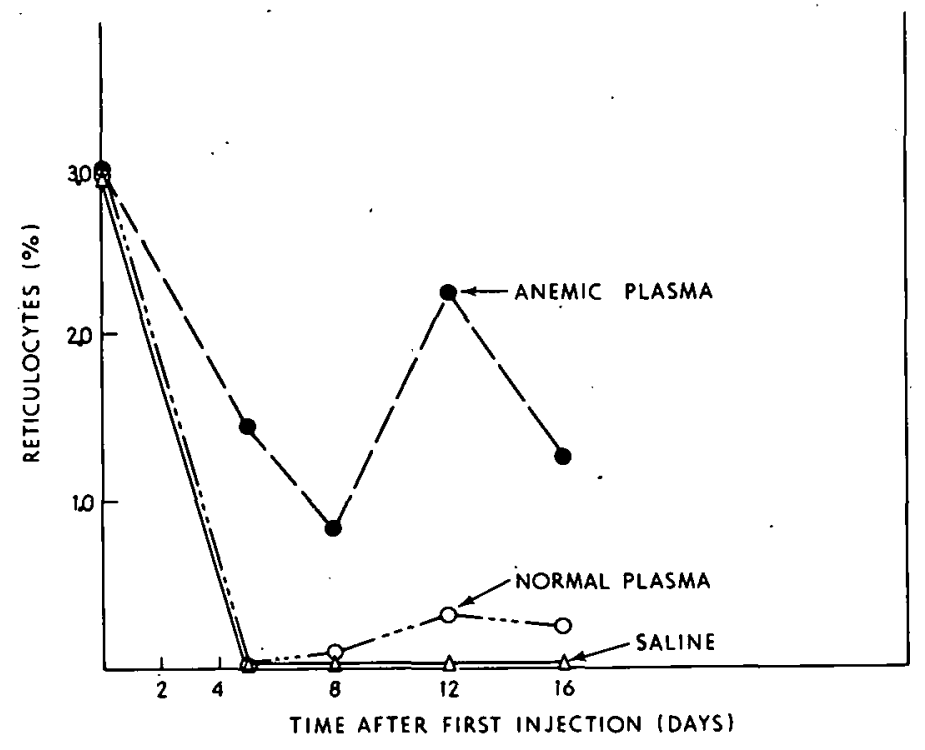

Figure 6. Effect of repeated 0.5 -cc intravenous injections of anemic and normal rabbit plasma on reticulocyte values of mice that received intraperitoneal injections of plasma beginning on same day that transfusions for polycythemia were initiated.

ma reached $0.25 \%$. The saline recipients remained reticulocyte-free through the 16 -day period of observation.

Histologic findings. Histologic differences between polycythemic mice that received anemic plasma and those that received saline or no injection were obvious at autopsy. The spleens of animals that had received anemic plasma were at least twice the size of those from saline-treated or control animals. The spleens from the polycythemic mice that had been given normal plasma were larger than those from the saline or "no injection" controls but smaller than those from the anemic plasma group. 
Histologically, the 4 groups were clearly distinguishable as follows: 1) Anemic plasma-treated polycythemic recipients. Islands of ectopic erythropoiesis in the portal triads of liver were easily distinguishable. Evidence of erythropoiesis was scattered throughout the bone marrow. The red pulp of spleen was packed solidly with erythropoietic tissue (Figure 7, D). The white pulp was sparsely populated with lymphocytes. 2) Normal plasma-treated polycythemic recipients. Definite islands of erythropoietic activity were found in the portal triads of liver but were less conspicuous than those observed in liver of recipients of anemic plasma. The red pulp of spleen had definite areas of erythropoietic proliferation as shown in Figure 7, B. The amount of erythropoietic tissue in the red pulp was clearly less than that observed in recipients of anemic plasma. 3) Saline-control polycythemic recipients. There were no indications of ectopic erythropoiesis in liver, and no significant evidence of erythropoiesis in bone marrow was seen. The marrow consisted primarily of megakaryocytes and granulocytes. As indicated in Figure 7, C, the red pulp of spleen was relatively acellular and there was no definite evidence of erythropoiesis. The white pulp stood out sharply in contrast. 4) "No injection" control polycythemic mice. Histologic findings in liver, bone marrow, and spleen in this group were identical with those for saline-injected control mice. A section of the spleen from such a mouse is shown for purposes of comparison in Figure 7, A.

\section{DISCUSSION}

In Part $\mathrm{III}^{5}$ of this series we have attempted to explain the mechanism whereby hypophysectomy, transfusion-induced polycythemia, and related experimental conditions alter red cell production. We have also tentatively proposed a theory to explain the mechanism by which erythropoietin is produced and by which erythropoiesis is controlled. This communication is largely designed to show that the data on reticulocyte production and the histologic evidence of erythropoiesis in hemopoietic tissue support the findings given in the preceding paper, which describes the use of incorporation of $\mathrm{Fe}^{59}$ into the red cell to study the state of erythrocyte production and to measure the effects of normal and anemic plasma in hypophysectomized rats and polycythemic mice. It is of considerable importance, however, to note that when one reduces erythropoiesis to an absolute zero baseline by transfusion-induced polycythemia, as measured by reticulocytes, $\mathrm{Fe}^{59}$ uptake values are $5 \%$ or less but never reach a zero baseline. We have demonstrated in polycythemic animals that the response to an anemic plasma preparation may not be significant by $\mathrm{Fe}^{59}$ red cell incorporation studies but that reticulocyte studies clearly indicate activity. On the other hand, as described in part III, ${ }^{5}$ when a substantial reticulocyte response occurs, $\mathrm{Fe}^{59}$ red cell incorporation clearly differentiates the anemic plasma-injected animals from the controls in the polycythemic recipients, and is equally as sensitive as in the hypophysectomized assay preparation.

The slight effect of normal plasma on the reticulocytes of the peripheral blood and the striking effect on splenic erythropoiesis probably represents the effect of a small amount of erythropoietin that is present in normal plasma. Our experience would indicate 

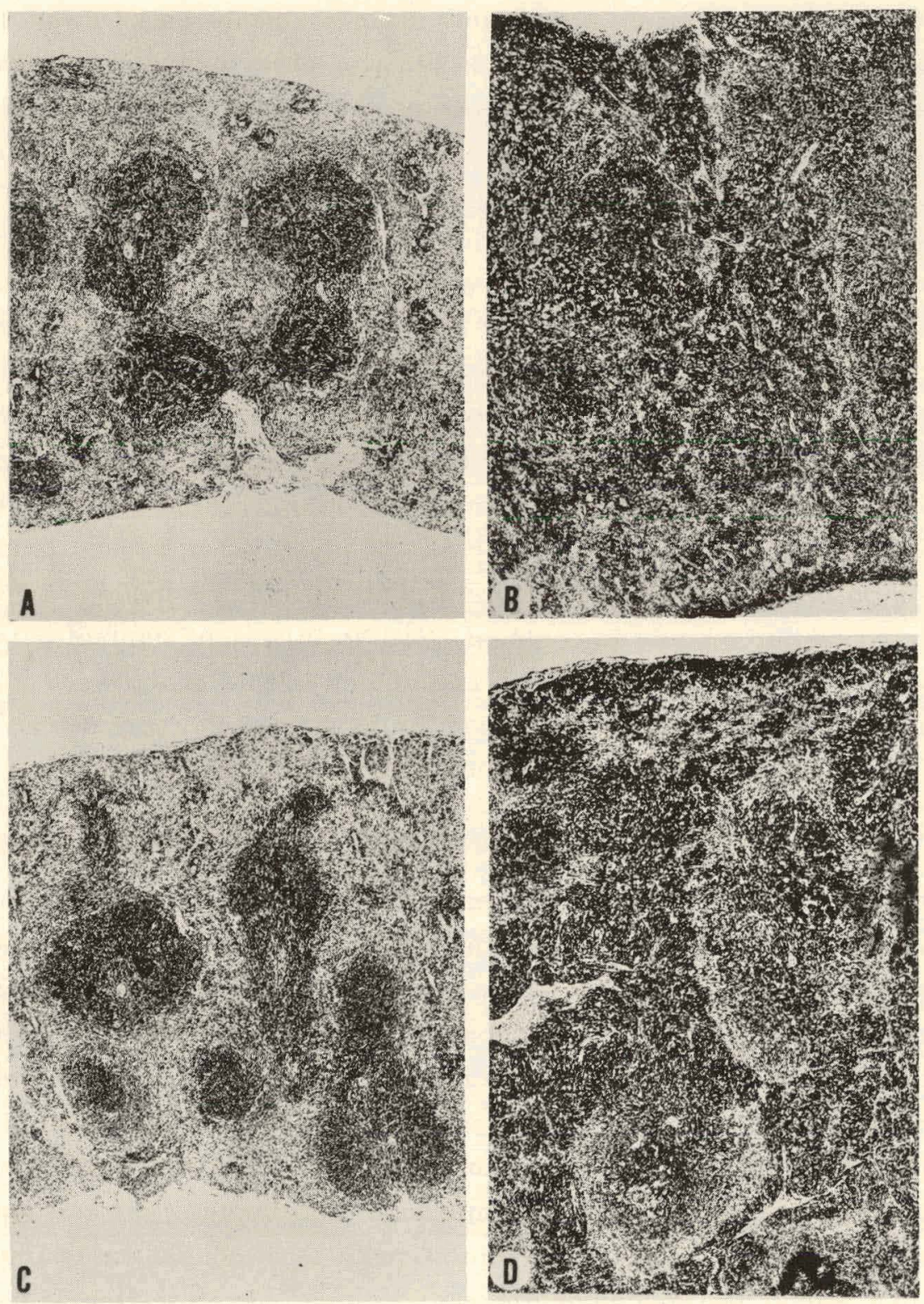

Figure 7. Histologic effect of $60.5-c c$ injections of anemic rat plasma compared with that of normal rat plasma on splenic erythropoiesis in mice with transfusion-induced polycythemia. Tissues were taken for study 8 days after first injection of plasma. A. "No injection" polycythemic control spleen. Red pulp is sparsely cellular. B. Spleen of normal plasmainjected polycythemic mouse. Red pulp is rather heavily populated with erythropoietic tissue. C. Spleen of saline-injected polycythemic control. Red pulp is sparsely cellular and there are no islands of erythropoiesis. D. Spleen of anemic plasmainjected polycythemic mouse. There is extreme erythropoietic activity in the red pulp and a moderate reduction in lymphopoietic cells in white pulp. 
that one could probably use weight, size, and gross appearance of the spleen of polycythemic mice as a simple index of erythropoietic effect of an unknown plasma. The histologic appearance of the spleen permits differentiation between anemic plasma and normal plasma or saline recipients on the basis of the amount of erythropoiesis in the red pulp. In preliminary studies we have found that normal plasma incubated at $37^{\circ} \mathrm{C}$ for 20 hours and administered thereafter according to the same dosage schedule as that used for normal or anemic plasma in polycythemic mice fails to increase the number of reticulocytes in polyoythemic mice.

In his early studies on transfusions, Robertson ${ }^{7}$ described the induction of polycythe$\mathrm{mia}$ in the rabbit and the effect of this procedure on erythropoiesis. He encountered increasing difficulty in maintaining a polycythemia as transfusion followed transfusion. We have found that it is hot difficult to produce and maintain a polycythemia in mice if washed homologous cells are used. However, the repeated injection of heterologous plasma makes the maintenance of a polycythemia more difficult.

\section{SUMMARY AND CONCLUSIONS}

1. Following hypophysectomy of rats, reticulocytes in the peripheral blood fall to a minimal level within a period of 3 to 4 weeks. This reduction represents a 5 - to 10 -fold decrease from the prehypophysectomy control. This reticulocyte decline is more rapid in 8 -week-old rats than in younger animals. 2. Administration of anemic plasma to hypophysectomized rats produces a reticulocyte rise that is many fold greater than that produced by normal plasma or saline. 3. Erythropoiesis, as measured by the number of reticulocytes in periphe ral blood, falls to zero in 6 days in mice made polycythemic by repeated intraperitoneal injections of homologous red cells. Anemic plasma obtained from rats or rabbits, when injected intravenously or intraperitoneally into polycythemic mice, produces a reticulocytosis many times greater than that observed from normal plasma. Normal saline produces no increase in reticulocytes. 4. In polycythemic mice and hypophysectomized rats, reticulocyte determinations in the peripheral blood and $\mathrm{Fe}^{59}$ red cell incorporation studies are of about equal sensitivity in measuring the response to anemic plasma.

\section{LITERATURE CITED}

1. Fried, W., I. Plzak, L. O. Jacobson, and E. Goldwässer. Proc. Soc. Exp. Biol. Med., $92: 203,19.56$.

2. Jacobson, L. O., L. Plzak, W. Fried, and E. Goldwasser. Nature, 177:1240, 1956.

3. Van Dyke, D. C., A. N. Contopoulos, B. S. Williams, M. E. Simpson, J. H. Lawrence, and H. M. Evans. Acta Haematologica, 11:203, 1954.

4. Von Bertalanffy, L. and R. R. Estwick. Am. J. Physiol., 177:16, 1954.

5. Fried, W., L. F. Plzak, L. O. Jacobson, and E. Goldwasser. Proc. Soc. Exp. Biol. Med., $94: 237,1957$. 
6. Sterling, K. and S. J. Gray. .J. Clin. Invest., 29:1614, 1950.

7. Robertson, O. H. J. Exp. Med., 26:221, 1917. 


\section{STUDIES ON ERYTHROPOIESIS. V. THE EFFECT OF COBALT ON THE PRODUCTION OF ERYTHROPOIETIN ${ }^{*}$}

By

E. Goldwasser, L. O. Jacobson, W. Fried, and L. F. Plzak

For nearly three decades it has been known that cobalt increases erythropoiesis in experimental animals. ${ }^{1}$ Cobaltous chloride given orally or parenterally for a period of several weeks induces and maintains a polycythemia in man and experimental animals. ${ }^{2-4}$ The precise mechanism by which cobalt exerts this action has not yet been clarified completely. Early studies indicated the cobalt acts directly by producing an anoxic condition in the marrow, ${ }^{5}$ while later work suggested an indirect anoxic effect on the marrow caused by the formation of cobalt-amino acid complexes. ${ }^{6,7}$ However, attempts to produce a depression in respiration of the marrow by the use of cobalt, either indirectly or directly, have failed. ${ }^{8}$ A recent study has shown that cobalt, at a concentration that does not affect respiration, depresses the in vitro synthesis of hemoglobin from glycine in short-term experiments. ${ }^{9}$ This seeming paradox has not yet been resolved.

Although the appreciable toxicity of cobalt limits its clinical applicability, it has been used to correct certain anemias that are refractory to all the usual therapeutic measures except transfusion or elimination of the underlying disease.

In a preliminary paper ${ }^{10}$ we presented data indicating that cobalt exerts its effect by stimulating the production of erythropoietin. This paper gives details and further evidence of this finding. As in previous reports; the term erythropoietin is used to designate the factor found in plasma of anemic animals that accelerates erythropoiesis when such plasma is injected into assay animals.

\section{EXPERIMENTAL}

Materials and Methods

Assay animals. Starved or hypophysectomized ${ }^{\dagger}$ rats were used to assay the various experimental plasma preparations for erythropoietin activity as described in previous publications. ${ }^{11-13}$ The assay method measures the per cent of injected $\mathrm{Fe}^{59}$ that is incorporated into red cells under standardized conditions. A minimum of 5 rats was used in each assay group.

Preparation of "cobalt plasma." Aliquots of a stock solution of cobaltous chloride $(0.025 \mathrm{M})$ were injected subcutaneously into rats and rabbits according to the schedules described for each separate experiment. After the indicated intervals, the treated animals

\footnotetext{
Reprinted from Blood, 13:55-60, 1958.

+ Obtained from Hormone Assay Laboratories, Chicago, Illinois.
} 
were bled by cardiac puncture, the plasma was separated and, if not used immediately, was stored at $-18^{\circ} \mathrm{C}$. When $\mathrm{Co}^{60}$ was used, it was mixed with aliquots of the stock solution before injection. Plasma derived from animals injected previously with cobalt is termed "cobalt plasma." Exactly similar methods were used for the other metal ions that were examined; the amounts used being limited by the toxic action of each metal.

Effect of cobalt on the incorporation of $\mathrm{Fe}^{59}$. The direct effect of cobaltous ion on the incorporation of $\mathrm{Fe}^{59}$ into red cells was studied by injecting $1 \mathrm{ml}$ of a cobalt solution containing $1.05 \mu$ moles each day for 2 days into hypophysectomized rats, then determining the incorporation of $\mathrm{Fe}^{59}$ as in the standard assay. The results shown in Table 1 reveal that $2.1 \mu$ moles of cobaltous ion stimulate the incorporation of iron into red cells. This finding necessitated the use of cobalt-containing controls as described below.

Table 1

EFFECT OF COBALTOUS ION ON THE INCORPORATION OF $\mathrm{Fe}^{59}$ INTO THE RED BLOOD CELLS

OF HYPOPHYSECTOMIZED RATS

\begin{tabular}{l|r}
\hline & $\%$ of $\mathrm{Fe}^{59}$ incorporated \\
\hline Normal plasma & $3.8 \pm 2.0^{*}$ \\
$2.1 \mu \mathrm{M} \mathrm{Co}{ }^{++}$ & $9.5 \pm 1.9$ \\
\hline Standard deviation of the mean.
\end{tabular}

Effect of cobalt plasma on the incorporation of $\mathrm{Fe}^{59}$. Cobalt plasma was produced by injecting $6 \mathrm{ml}$ of the stock solution of cobalt into $400-\mathrm{g}$ donor rats, which were sampled 18 hours later. This cobalt plasma was assayed in hypophysectomized and normal rats with the results shown in Table 2 . There was an unmistakable stimulation of iron incorporation by the cobalt plasma. By mixing $\mathrm{Co}^{60}$ with the stock solution of $\mathrm{CoCl}_{2}$ and measuring the amount of isotope remaining in the plasma after 24 hours, we were able to show that about $0.4 \%$ of the original amount of cobalt that had been injected was present in the $4 \mathrm{ml}$ of plasma that was used for assay. As might be inferred from the data in Table 1 , this amount of

Table 2

EFFECT OF COBALT PLASMA ON THE INCORPORATION OF $\mathrm{Fe}^{59}$ INTO THE RED BLOOD CELLS OF HYPOPHYSECTOMIZED AND NORMAL RATS

\begin{tabular}{|c|c|c|c|c|}
\hline " & \multicolumn{4}{|c|}{$\%$ of $\mathrm{Fe}^{59}$ incorporated } \\
\hline & \multicolumn{2}{|c|}{ Hypophysectomized } & \multicolumn{2}{|c|}{ Normal } \\
\hline Saline & 2.6 & $\pm 0.6^{\circ}$ & 26.7 & \pm 9.2 \\
\hline Cobalt'Plasma & 19.4 & \pm 7.4 & 35.6 & \pm 1.1 \\
\hline
\end{tabular}


cobalt $(0.6 \mu$ moles $)$ is too small to elicit a response of the magnitude seen in Table 2 , and the observed erythropoietic effect was therefore not attributable to free cobaltous ion. Similar controls will be described in later experiments.

The relationship between the erythropoietic activity of cobalt plasma and the amount of cobalt injected into donors was studied with the results shown in Table 3 . Three hundred$\mathrm{g}$ donor rats were given single injections of cobalt solution, with the exception of the highest dose which, because of its toxicity, was given in a divided dose, 2 hours apart. The plasma was drawn after 24 hours and assayed in hypophysectomized rats. The data from this experiment reveal a rough proportionality between the amount of cobalt given to donor animals and the response of recipient animals to the resulting cobalt plasma.

Table 3

EFFECT OF AMOUNT OF $\mathrm{Co}^{++}$INJECTED INTO DONOR RATS ON ERYTHROPOIETIC ACTIVITY OF COBALT PLASMA (ASSAYED IN HYPOPHYSECTOMIZED RATS)

\begin{tabular}{c|c|c}
\hline$\mu \mathrm{M} \mathrm{Co}^{++}$injected & $\%$ of $\mathrm{Fe}^{59}$ incorporated & Difference from control \\
\hline 0 & $2.6 \pm 0.6$ & -- \\
37.5 & $8.0 \pm 3.3$ & 5.4 \\
75.0 & $10.6 \pm 6.1$ & 8.0 \\
150.0 & $15.9 \pm 3.1$, & 13.3 \\
\hline
\end{tabular}

Time course of erythropoietin production. The time course of the appearance of erythropoietic activity in this plasma of donor animals was determined. Each donor ani $\mathbf{-}^{*}$. mal was given $75 \mu$ moles of $\mathrm{Co}^{++}$in a single injection, and enough animals were bled at each time interval to yield a minimum of $20 \mathrm{ml}$ of plasma. The cobalt plasmas were then assayed in starved rats with the results shown in Figure 1. After a lag period of about 4 hours, there was a sharp rise in the content of erythropoietin in the cobalt plasma. The maximum titer was reached at about 12 hours. A curve derived from these data could be indicative of the action of either of two mechanisms. A storage site of the hormone may be stimulated to discharge its content of erythropoietin, or the site of synthesis may be stimulated for a short time to produce the factor, at an accelerated rate, which has a short half-life in the plasma. The former explanation seems the less likely in view of the lag period, and more importantly, the known effect of cobalt in producing a true polycythemia. Further evidence that cobalt exerts its effect by stimulating synthesis is provided by additional data showing that 72 hours after an initial stimulus with cobalt, the erythropoietin titer of the plasma had returned to control levels. If however, the animals were given another injection of cobalt and the plasma was sampled 6 hours later, the titer rose to about the same level as it had 6 hours:after the first injection of cobalt.

That the effects seen with cobalt plasma in Figure 1 were not caused by residual 


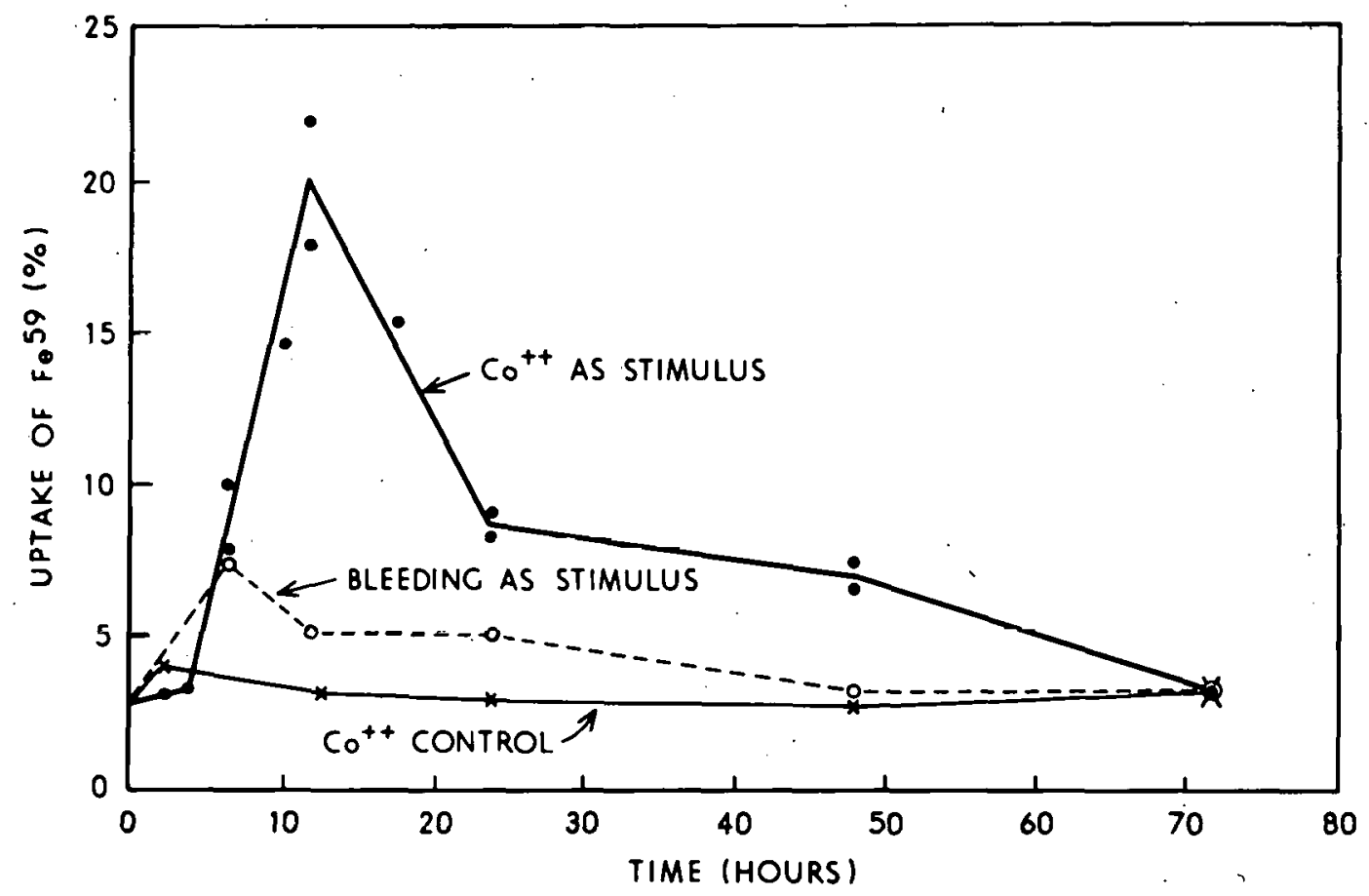

Figure 1. Time course of erythropoietin formation after cobalt stimulation. Each point represents the average of values obtained from a group of 5 assay rats.

amounts of cobalt in the plasma can be seen upon examining the curve marked cobalt control (Figure 1). The amount of cobalt present in the plasma was determined by means of a tracer quantity of $\mathrm{Co}^{60}$ as described above. An amount of unlabeled cobalt calculated from the $\mathrm{Co}^{60}$ content to be in the plasma at each time interval, was then mixed with normal plasma. This plasma-plus-cobalt was used as a control for cobalt plasma containing the same amount of the ion. The stimulated incorporations of Fe ${ }^{59}$ seen were, therefore, not due to cobaltous chloride. The possibility remains that some form of cobalt other than free cobaltous ion may be responsible for the erythropoietic effect. Crafts ${ }^{14}$ has shown that microgram quantities of vitamin $B_{12}$ have no effect on erythropoiesis in hypophysectomized animals, and we have found that as much as $1.0 \mathrm{mg}$ of $\mathrm{B}_{12}$ does not stimulate incorporation of $\mathrm{Fe}^{59}$. When erythropoietin has been completely characterized it will be possible to determine whether the material in cobalt plasma is identical with that in plasma from anemic animals. Evidence has been accumulated showing that some of the gross properties of the active principles in the two types of plasma are similar. The erythropoietic activity contained in both anemic and cobalt plasmas is, in large part, retained after precipitation of the major portion of the plasma proteins by either heat denaturation ${ }^{15}$ or by precipitation with perchloric acid. In addition, extracts of both types of plasma retain activity after prolonged dialysis and lyophilization.

Effect of bleeding on erythropoietin production. A single massive bleeding acts in the 
same manner as cobalt, as a stimulus to increase plasma erythropoietin. In this experiment, $8 \mathrm{ml}$ of blood was removed from each donor animal $(300 \mathrm{~g})$ by cardiac puncture, with a resulting hematocrit of 27 . At the indicated intervals, each group of rats was then bled as a source of plasma, and the plasma was assayed in starved rats (Figure 1). While the observed stimulus is considerably less than that seen after repeated bleedings or after cobalt, it does follow a time course similar to that seen with cobalt plasma although the peak of erythropoietin titer. is reached sooner.

Effect of other metal ions on erythropoietin production. The effect of other heavy metal ions, as well as that of a cobaltic complex ion, was studied in order to determine whether the stimulation of erythropoietin synthesis was specific for cobaltous ion or, perhaps, due to general heavy metal toxicity. The metal ions were chosen because of their chemical or toxicological similarity to cobalt. The data in Table 4 indicate that other toxic heavy metals have no effect in stimulating the production of erythropoietin. Surprisingly, cobaltic hexamine chloride did have some effect, which may possibly be due to reduction of the complex ion, but evidence of this is not yet available.

Table 4

EFFECT OF METAL IONS ON FORMATION OF PLASMA ERYTHROPOIETIN

\begin{tabular}{l|c|cc}
\hline \multicolumn{1}{c|}{ Metal salt } & $\begin{array}{c}\text { Amount injected } \\
\text { into donor rats } \\
(\mu \mathrm{M})\end{array}$ & $\begin{array}{c}\% \text { of } \mathrm{Fe}^{59} \text { incorporated } \\
\text { by recipient rats }\end{array}$ \\
\hline $\mathrm{MnSO}_{4}$ & 186 & 4.5 & \pm 0.9 \\
$\mathrm{NiCl}_{2}$ & 114 & 3.4 & \pm 0.5 \\
$\mathrm{Fe}^{++7}$ & 317 & 3.9 & \pm 0.2 \\
$($ ammonium citrate) & 57 & 3.8 & \pm 1.0 \\
$\mathrm{FeSO}_{4}$ & 57 & 8.7 & \pm 2.0 \\
$\mathrm{Co}\left(\mathrm{NH}_{3}\right)_{6} \mathrm{Cl}_{3}$ & 57 & 11.9 & \pm 3.2 \\
$\mathrm{CoCl}$ & & 4.6 & \pm 0.6 \\
Saline & -- & \multicolumn{3}{c}{.} \\
\hline
\end{tabular}

\section{DISCUSSION}

These data show that the erythropoietic effect produced by cobaltous ion is probably caused by an increase in circulating plasma erythropoietin. The mechanism by which cobalt increases the production of erythropoietin is as obscure as the mechanism by which bleeding or phenylhydrazine does the same thing. We would suggest that production of erythropoietin is stimulated by a relative anoxia and that cobalt may act by producing an anoxic state in the kidney ${ }^{22}$ rather than in the bone marrow.

These findings are of interest from the clinical point of view. If, as our studies indicate, the erythropoietic effect of cobalt is based upon an increase in plasma erythropoietin, then the clinical usefulness of the hormone is obvious. There are a number of disease 
conditions and experimental states in which the associated anemia is reported to be influenced beneficially by the administration of cobalt. Cobalt will favorably influence the anemia of hypophysectomy, ${ }^{14}$ protein deficiency, ${ }^{16}$ chronic renal disease, ${ }^{17}$ chronic inflammation, ${ }^{18}$ and cancer. ${ }^{19}$ We have demonstrated that plasma made rich in erythropoietin by the use of cobalt is as effective in producing an erythropoietic response in hypophysectomized rats, starved rats, normal rats, and transfusion-induced polycythemic mice 20 as is plasma from animals that have been bled or have been given phenylhydrazine.

The rapidity of the response to cobalt (and to phlebotomy) is important in the search for the site of production of erythropoietin. From our experience and that of others, it is already known that removal of the pituitary, thyroid, adrenals, or gonads, does not diminish the production of erythropoietin in response to bleeding or phenylhydrazine. ${ }^{11}$ Extracts of various organs do not yield materials with erythropoietic activity either. ${ }^{21}$ Because of the rapid death that follows hepatectomy and nephrectomy, we were unable to use the usual bleeding or phenylhydrazine schedule to study erythropoietin production in the se two experimental states. In preliminary experiments, we have used the rapid response to cobalt to show that removal of $85-90 \%$ of the liver does not interfere with erythropoietin production. Removal of both kidneys, however, suppresses or eliminates the production of erythropoietin after the administration of cobalt or after acute hemorrhage. 22

\section{SUMMARY}

It has been shown that plasma from animals which have been injected with cobaltous chloride rapidly develops a high titer of erythropoietin.

The gross properties of the active material appear to be the same from cobalt-treated as from phenylhydrazine-treated animals.

Other metal ions and a complex ion have been studied as stimulants for erythropoietin formation; none was as effective as cobaltous ion with the exception of cobaltic hexamine.

\section{LITERATURE CITED}

1. Waltner, K. and K. Waltner. Kobalt und blut. Klin. Wchinschr., 8:313, 1929.

2. Schultze, M. O. Physiol. Rev., 20:37, 1940.

3. Berk, L., J. H. Burchenal, and W. B. Castle: New England J. Med., 240:724, 1949.

4. Grant, W. C. and W. S. Root. Physiol. Rev., 32:449, 1952.

5. Barron, A. G: and E. S. G. Barron. Proc. Soc. Exp. Biol. Med., 35:407, 1936.

6. Burk, D., J. Hearson, L. Caroline, and A. L. Schade. J. Biol. Chem., 165:723, 1946.

7. Michaelis, L. Arch. Biochem., 14:17, 1947.

8. Warren, C. O., Q. D. Schubmehl, and I. R. Wood. Ám. J. Physiol., 142:173, 1944.

9. Laforet, M. T. and E. D. Thomas. J. Biol. Chem., 218:595, 1955.

10. Goldwasser, E., L. O. Jacobson, W. Fried, and L. Plzak. Science, 125:1085, 1957. 
11. Plzak, L. F., W. Fried, L. O. Jacobson, and W. F. Bethard. J. Lab. Clin. Med., 46: 671,1955 .

12: Fried, W., L. Plzak, L. O. Jacobson, and E. Goldwasser. Proc. Soc. Exp. Biol. Med., $92: 203,1956$.

13. Fried, W., L. F. Plzak, L. O. Jacobson, and E. Goldwasser. Proc. Soc. Exp. Biol. Med., 94:237, 1957.

14. Crafts, R. C. Blood, 7:863, 1952 .

15. Borsook, H. A., A. Graybiel, C. Keighley, and E. Windsor. Blood, 9:734, 1954.

16. Orten, J. M. and A. U. Orten. Am. J. Physiol., 139:399, 1943.

17. Gardner, F. H. J. Lab. Clin. Med., 41:56, 1953.

18. Wintrobe, M. M., M. Grinstein, J. J.. Dubash, S. R. Humphrys, H. Ashenbrucker, and W. Worth. Blood, 2:323, 1947 .

19. Shen, S. C. and F. Homburger. J. Lab. Clin. Med., 37:182, 1951.

20. Jacobson, L. O., E. Goldwasser, L. F. Plzak, and W. Fried. Proc. Soc. Exp. Biol. Med., 94:243, 1957.

21. Gordon, A. S., S. J. Piliero, P. T. Medici, C. D. Siegel, and M. Tannenbaum. Proc. Soc. Exp. Biol. Med., 92:598, 1956.

22. Jacobson, L. O., E. Goldwasser, W. Fried, and L. Plzak. Nature, 179:633, 1957. 


\section{STUDIES ON ERYTHROPOIESIS VI. ERYTHROPOIETIN IN HUMAN PLASMA*}

By

C. W. Gurney, E. Goldwasser, and C. Pan

The mechanisms which regulate erythropoiesis, have been under intensive investigation in recent years. Carnot and Deflandre ${ }^{1}$ were the first to suggest a humoral mechanism was of importance in this regulation. Investigations prior to 1952 , largely confined to animals, were summarized in the extensive review by Grant and Root, ${ }^{2}$ and at that time evidence favored the humoral control of erythropoiesis. The factor responsible for this control has been referred to as erythropoietin by Bonsdorff and Jalavisto. 3

A significant advance was made by Borsook, Graybiel, Keighley, and Windsor ${ }^{4}$ when they demonstrated an erythropoietic stimulating factor in the filtrate obtained from heatdenatured anemic rabbit plasma. Although obtained from anemic rabbits, this filtrate could be assayed in the normal rat. The appearance of an erythropoietic factor in the plasma of rats or rabbits made anemic by phlebotomy or injection of phenylhydrazine has been demonstrated by numerous investigators. ${ }^{5-9}$

Recent investigators have turned their attention to the significance of erythropoietin in the human being. Contopoulos and his co-workers ${ }^{10}$ have demonstrated a plasma factor from blood of patients with polycythemia vera which is capable of stimulating erythropoiesis in the rat. Linman and Bethell ${ }^{11}$ have demonstrated stimulation of erythropoiesis in the normal rat by injections of extracts of plasma from patients with polycythemia vera and secondary polycythemia. Piliero and co-workers ${ }^{12}$ have found an erythrocyte stimulating factor in the plasma of patients with Cooley's anemia and sickle-cell anemia. Their report also summarizes previous work with human plasma by other investigators.

The purpose of this report is to record the demonstration of erythropoietin in the extract of heat-denatured plasma obtained from anemic patients. This demonstration has been facilitated by the development of an assay procedure by Plzak, Fried, Jacobson, and Bethard ${ }^{13}$ and depends on the increased incorporation of radioiron into erythrocytes of rats stimulated by the intravenous injection of erythropoietin. Although Gordon, Piliero, Tannenbaum, and Siegel ${ }^{14}$ had previously demonstrated that the hypophysectomized rat was capable of responding to anemic rabbit plasma extract with increases of peripheral red cell, hemoglobin, hematocrit, and reticulocyte values, Jacobson and his co-workers 15,16 first clearly demonstrated that the hypophysectomized rat was an extremely sensitive animal for assay of erythropoietin activity and that a dramatic increase of $\mathrm{Fe}^{59}$ incorporation into the animal's erythrocytes followed only 2 or 3 injections of anemic rat plasma.

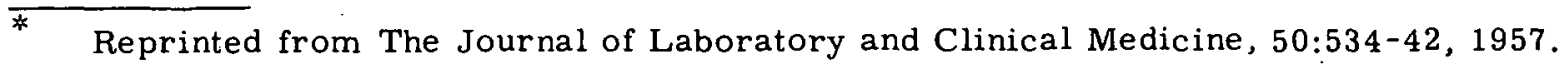


The significance of this assay method rests in the great increase of red cell $\mathrm{Fe}^{59}$ incorporation, often several hundred per cent greater than that produced by normal plasma, requiring only small amounts of anemic plasma. It has, therefore, become possible to avoid lengthy assays in which small rises in peripheral hemoglobin, red count, or hematocrit following many injections of a plasma extract represent activity of the extract being tested. In the present study this assay procedure was used in an attempt to determine the presence of erythropoietin in normal and ancmic human plasma.

\section{METHODS ,}

Fifty to $150 \mathrm{ml}$ of blood from anemic patients was collected in $250-\mathrm{ml}$ bottles, each containing $1 \mathrm{ml}(1,000$ units) of heparin. Normal control blood was collected in $500-\mathrm{ml}$ bottles, each containing $2 \mathrm{ml}$ of heparin. Immediately after collection the plasma was separated by centrifugation in the cold, removed, and stored in the Deepfreeze until extraction.

Plasma was extracted by the boiling method as described by Borsook and co-workers. 4 The plasma was brought to a $\mathrm{pH}$ of 5.5 by addition of 0.1 normal hydrochloric acid, put into a boiling water bath for 10 minutes, and filtered. The precipitate was washed twice with an equal volume of distilled water, all filtrates being pooled. Employing a rotary evaporator, the filtrate was then concentrated to the volume of the original plasma specimen. Since normal plasma failed to demonstrate erythropoietic stimulating activity, we considered the possibility that erythropoietin might be present in titers insufficient to demonstrate in normal plasma by the assay system employed, and some specimens of normal plasma were, therefore, concentrated to one-tenth the original volume. Such specimens were then dialyzed for 48 hours in order to remove the excessive amounts of electrolytes present as a result of concentration. After concentration to the desired volume, the pH was adjusted to 7.5 by the addition of 0.1 normal sodium hydroxide.

An extract of normal plasma was also prepared using perchloric acid. A volume of 10 per cent perchloric acid equal to the plasma specimen was added to the plasma slowly with continuous stirring. The precipitate was washed two times with 5 per cent perchloric acid; each washing was with a volume equal to one-half the original plasma volume. The supernatant fluid and washings were placed in a Visking Casing bag, dialyzed against distilled water for 72 hours, and concentrated to the desired volume; the $\mathrm{pH}$ was adjusted to 7.5 by the addition of $0.1 \mathrm{~N}$ sodium hydroxide.

Hypophysectomized male Sprague-Dawley rats, 130 to 180 grams in weight, were used. The animals in each assay were 8 to 15 days posthypophysectomy when the assay was begun. On 2 successive days, $2 \mathrm{ml}$ of anemic plasma extract were injected in the tail vein while the animals were under light ether anesthesia. On the third day, a tracer dose of 1 to $2 \mu \mathrm{c}$ of $\mathrm{Fe}^{59}$ (activity approximately 2,000 mc per gram of iron) in saline, buffered to $\mathrm{pH} 7.5$ with sodium citrate, was injected. Sixteen hours after iron injection, $1 \mathrm{ml}$ of blood was obtained by cardiac puncture for assay. Between successive cardiac punctures, the syringe used was rinsed in normal saline and finally in heparin (1,000 units per milliliter). The thin film of heparin left in the syringe was sufficient to prevent clotting. 
Blood samples and two aliquots of the standard prepared at the time of radioiron injection were counted in a Nancy Wood scintillation counter. Assuming a blood volume of 5 per cent of body weight, ${ }^{13}$ and correcting counts for background, the per cent $\mathrm{Fe}^{59}$ incorporation in red cells at 16 hours was calculated. Per cent iron incorporation =

net counts of blood per minute $/ \mathrm{ml} x$ body weight in grams $x 0.05$ net counts of standard/ml

Results are expressed as average per.cent uptake \pm one standard deviation. Starved, normal, male Sprague-Dawley rats of the same age and weight as the hypophysectomized animals were also occasionally used for assay. 17 These animals had no food for 24 hours prior to the beginning of the assay, and were maintained in the starved condition throughout the assay, water being given ad libitum.

At least one normal plasma control and a saline control assay was run every 2 weeks over the duration of the entire study. A normal plasma control was not, however, run with every assay.

\section{RESULTS}

Studies on normal plasma. The average uptake obtained when the extracts of individual heat-denatured plasma specimens from 10 normal donors with hemoglobin above 14 g per cent was used in hypophysectomized rats was 3.1 per cent; this value does not differ appreciably from an uptake of 3.4 per cent when normal saline was used. In starved rats, 3.5 per cent uptake was obtained with extract of normal plasma from 6 donors, and an uptake of 3.2 per cent followed the injection of normal saline. These results are summarized in Table 1. It seemed likely to us that normal plasma was not devoid of erythropoietin, but that the concentration was so small as to escape detection by this assay. To test this possibility, after precipitation of proteins by heat or perchloric acid, the supernatant fluid was concentrated 10 times. The incorporation of $\mathrm{Fe}^{59}$ into red cells was suf-

Table 1

INFLUENCE OF EXTRACT OF NORMAL HUMAN PLASMA ON PER CENT OF $\mathrm{Fe}^{59}$ INCORPORATION IN RAT ERYTHROCYTES ${ }^{*}$

\begin{tabular}{|c|c|}
\hline $\begin{array}{l}\text { Assay of heat-denatured plasma from } \\
10 \text { normal human donors assayed in } \\
49 \text { hypophysectomized rats }\end{array}$ & $3.1 \pm 1.1 \%$ \\
\hline Saline control in 40 hypophysectomized rats & $3.4 \pm 1.4 \%$ \\
\hline $\begin{array}{l}\text { Assay of heat-denatured plasma from } \\
5 \text { normal human donors assayed in } \\
22 \text { hypophysectomized rats }\end{array}$ & $3.5 \pm 1.7 \%$ \\
\hline Saline control in 25 starved rats & $3: 2 \pm 1.1 \%$ \\
\hline
\end{tabular}


ficiently increased, when compared to incorporation following injection of saline or unconcentrated plasma extracts to indicate that erythropoietin is present in normal plasma. The se results are summarized in Table 2 .

Table 2

ERYTHROPOIETIC ACTIVITY OF FRACTIONATED CONCENTRATED NORMAL PLASMA (5 HYPOPHYSECTOMIZED RATS IN EACH GROUP)

\begin{tabular}{l|l|r}
\hline Heat-denatured & $\begin{array}{l}10 \mathrm{x} \text { normal concentration, dialyzed } \\
\text { Normal concentration, dialyzed }\end{array}$ & $\begin{array}{r}12.6 \pm 2.1 \% \\
2.6 \pm 1.2 \%\end{array}$ \\
Perchloric acid & $10 x$ normal concentration, dialyzed & $7.6 \pm 2.5 \%$ \\
& Normal concentration, dialyzed & $2.8 \pm 1.3 \%$ \\
\hline
\end{tabular}

Assay of plasma from anemic patients. Twenty-one plasma specimens were obtained from 18 patients with anemia. Twelve were positive, and 9 were considered equivocal or negative. At this time, we prefer to consider only those assays áveraging 7 per cent or more in hypophysectomized rats as positive (control $=3.1$ per cent), although, undoubtedly, lower values could be considered positive if larger numbers of animals were used in each assay. Results of these assays are summarized in Table 3.

In the first patient, hypoplastic anemia was secondary to Atabrine which had been administered on 3 occasions for treatment of chronic discoid lupus erythematosus of the face and scalp, each course being terminated because of the development of anemia. The patient was referred to the University of Chicago Clinics when, after discontinuance of the last course of Atabrine, the red count and hemoglobin continued to fall. There was no evidence for kidney disease or other systemic disease in the history, physical examination, or laboratory studies. Plasma was obtained on 4 occasions during the course of the illness. The first 2 specimens were strongly positive. The plasma for each of these assays was drawn immediately prior to transfusion of whole blood. The third plasma sample was obtained 4 days after transfusion of blood to hemoglobin of $10.8 \mathrm{~g}$ per cent, and on this occasion, activity was no longer demonstrable. The patient subsequently improved, and the hemoglobin fell slowly and has temporarily stabilized at a level above $9 \mathrm{~g}$. The last plasma specimen was obtained at this time, and again was negative.

The second patient was critically ill with a hypoplastic anemia of unknown etiology when admitted to the hospital, and for this reason, phlebotomy was considered contraindicated. However, from blood removed from the heart at post-mortem examination, 6 hours after death, it was possible to obtain plasma which still yielded a positive result, the average uptake in hypophysectomized rats being 7.2 per cent.

The third patient with hypoplastic anemia of unknown etiology, of 6 months' duration, on 2 occasions revealed virtually complete aplasia on both smear and section of the material obtained. Twenty-six and nine-tenths per cent of the tracer dose of $\mathrm{Fe}^{59} \mathrm{Cl}_{3}$ was in- 
Table 3

PER CENT Fe ${ }^{59}$ INCORPORATION IN RAT ERYTHROCYTES AFTER INJECTION OF BOILED EXTRACT OF ANEMIC PLASMA

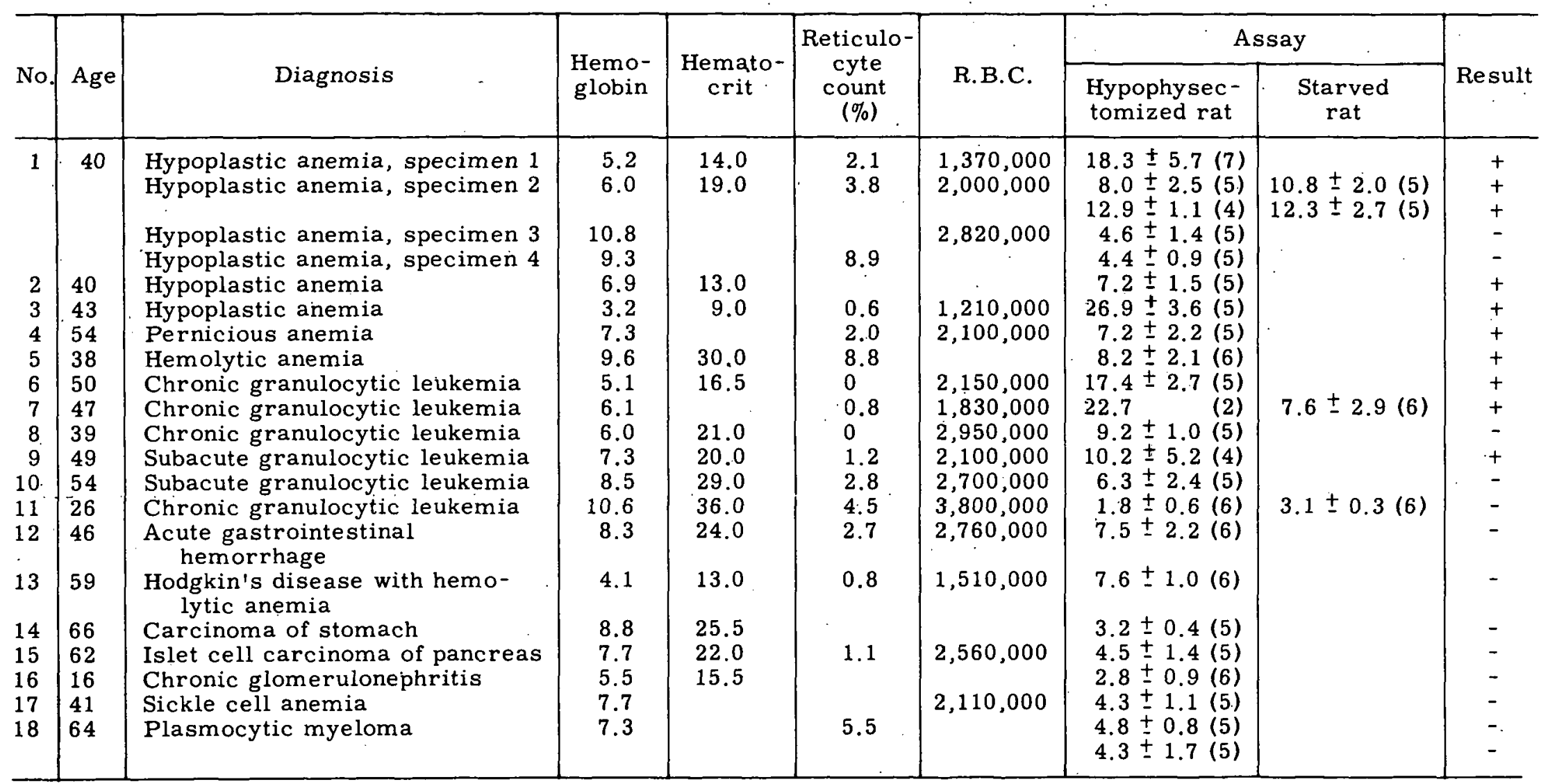

Number in parentheses refers to number of animals in each assay.

$+=$ Positive assay.

- = Negative assay. 
corporated in the rat red cells. It has been shown that radioactive iron is removed from the plasma within 4 to 6 hours after its injection, ${ }^{18}$ but this amount of $\mathrm{Fe}^{59}$ incorporation was so spectacular that we wished to be sure we were measuring $\mathrm{Fe}^{59}$ intimately associated with erythrocytes, and not plasma iron mobilized from stores into plasma. Therefore, to each $1-\mathrm{ml}$ blood specimen, $5 \mathrm{ml}$ of normal saline was added, and after centrifugation, 5 $\mathrm{ml}$ of supernatant fluid (saline and plasma) was removed. The remaining $1 \mathrm{ml}$, consisting of red cells, some plasma, and saline, was again counted and the calculated uptake was 26.4 per cent. The close agreement of activity of samples before and after washing demonstrates practically all the $\mathrm{Fe}^{59}$ is associated with the red cells, and little is free in the plasma.

Plasma from a primaquine-sensitive subject ${ }^{*}$ was obtained for assay on the fifth day of primaquine ingestion. Following administration of the drug, the subject responded with an acute hemolytic episode with the hematocrit falling from 45 to 30 per cent in 5 days. The plasma of this patient was positive for erythropoietin activity, averaging 8.2 per cent.

Six leukemic patients are included in this study to date. The extract of plasma from Patient 6 assays strongly positive. Although 2 of 5 animals showed a strong positive assay to extract of plasma from Patient 7 , the other 3 animals in this assay group died. Sufficient plasma was available for assay in starved rats, and although the magnitude of the increase of $\mathrm{Fe}^{59}$ incorporation into red cells is smaller, the result is positive. Plasmas from $\mathrm{Pa}$ tients 8 and 9 were positive. In keeping with our arbitrary assumption that incorporation of 7 per cent or more of the administered dose is required before an assay is considered positive, plasma from Patient 10 is classified as negative, although 6.3 per cent incorporation clearly exceeds any of the control values. Patient 11 had chronic granulocytic leukemia accompanied by mild anemia. Assays of extracts of his plasma were negative in both hypophysectomized and starved rats.

Positive results were obtained when extracts of plasma from patients with pernicious anemia, acute gastrointestinal hemorrhage, and Hodgkin's disease with anemia were assayed.

Diagnoses of patients whose plasma extract was negative or equivocal are listed in Table 3. Only Patients 11 and 16 were in a good state of nutrition. Patient 17 was in a poor state of nutrition and has persistently in the last year had a hemoglobin under $9 \mathrm{~g}$. The remaining patients were cachectic and considered to be approaching terminal status at the time blood was obtained for assay.

\section{DISC USSION}

The rats used for assay in this study have plasma volumes of approximately $3.5 \mathrm{ml}$. Therefore, it is logical to inquire as to why the erythropoietin in $4 \mathrm{ml}$ of normal plasma is not sufficient to stimulate erythropoiesis. Although we cannot answer this question at the present time, we belleve there is loss of activity of plasma after removal from the

* Kindly supplied by Drs. Alf Alving and Stanley Schrier. 
body. ${ }^{19}$ We are not now able to ascertain exactly how much erythropoietin is lost in the extraction employed here, but preliminary studies in our laboratories suggest about 50 per cent loss. ${ }^{19}$ If the rate of in vivo turnover is great, it may be that several times that amount of erythropoietin present in the normal rat at any one time would have to be given to the hypophysectomized or starved rat over a 2-day period in order to increase erythropoiesis. And finally, if under physiologic circumstances the rat should have a higher concentration of erythropoietin than the human, concentrations which would be normal for the latter would not be sufficient to produce an optimal response in the rat.

It is apparent that without concentrating the plasma extract, an active erythropoietic stimulating principle can be demonstrated in the heat denatured extract of plasma from human beings with a variety of anemias. It is not entirely clear at this time why a high titer of erythropoietin cannot be demonstrated in the plasma of all anemic subjects. A recent abstract by Prentiss and Mirand ${ }^{20}$ reports demonstration of erythropoietic activity in plasma of 10 to 15 patients with anemia, using the assay procedure first employed by Fried, Plzak, Jacobson, and Goldwasser. ${ }^{16}$ The diagnoses associated with the anemias were not stated. In their study the extract was concentrated 3 times. It is probable that some of our extracts which were negative would have been positive had the plasma been concentrated. We chose not to concentrate plasma extracts in this initial clinical study for two reasons. First, we have been reluctant to remove routinely more than $50 \mathrm{ml}$ of blood from severely anemic patients until we had thoroughly evaluated the results we could obtain by assaying a series of anemic plasmas without concentrating them. Second, if it is to give the most meaningful results, concentration of anemic plasma should be as many times as is required to demonstrate activity in normal, nonanemic plasma. Although we have demonstrated activity in normal plasma extracted by perchloric acid precipitation or heating and concentrated 10 times, we have not yet determined in a large series of nor mal plasma specimens the minimum number of times the filtrate from heat denatured normal plasma must be concentrated in order to demonstrate activity. Concentration of extracts of anemic plasma an arbitrary number of times may yield a few more positive assays. It will not, however, make negative results any more meaningful. Negative assays will be significant only when they indicate decreased concentrations of erythropoietin in plasma of anemic subjects. We have chosen not to concentrate extracts of anemic plasma until we have determined the number of times we must concentrate them in order to make a negative result indicative of decreased erythropoietin concentrations.

It may be, however, that failure to demonstrate erythropoietin in the plasma of all anemic patients cannot in every instance be attributable to insensitivity of the assay method. It appears possible to us that some anemic states may be accompanied by and to some degree attributable to a decreased concentration of erythropoietin, with a new steady state being established at hemoglobin levels less than normal.

Bethard and Wissler ${ }^{21}$ have demonstrated reduction of the rate of erythropoiesis in protein depleted rats as measured by $\mathrm{Fe}^{59}$ uptake, and Fried, Plzak, Jacobson, and Goldwasser ${ }^{17}$ have reported a decreased rate of erythropoiesis in acutely starved animals. It 
may be that in some patients, as in Patients 14 and 15 with carcinoma, starvation contributes to decreased erythropoiesis by decreasing erythropoietin production. Finally, in light of recent evidence reported by Jacobson and associates ${ }^{22}$ suggesting that erythropoietin is produced in the kidney, it is interesting to speculate that decreased production of erythropoietin may have contributed to failure to demonstrate activity in the extract of anemic plasma of a patient with chronic renal disease. Excessive excretion of erythropoietin in chronic renal disease is still another possibility which warrants investigation, particularly since an erythropoietic stimulating factor has been demonstrated in the urine of an anemic patient by Piliero and co-workers. ${ }^{12}$

The appearance of increased concentration of erythropoietin in animals following bleeding or hemolysis, ${ }^{4-19,13-16}$ the high concentrations of erythropoietin in several of our patients, and the prompt disappearance of the high concentration in one patient following blood transfusion suggests to us the possibility that the homeostatic mechanism by which a patient responds to anemia by increased erythropoiesis is mediated through production of increased amounts of erythropoietin. If future investigation substantiates this hypothesis, it is apparent the assay method as now employed is not very sensitive, since reticulocyte counts as high as 8.9 per cent were found in patients whose plasma failed to demonstrate activity on bio-assay.

It is clear that a relationship does not of necessity exist between severity of anemia and erythropoietin concentration or degree of reticulocytosis and erythropoietin concentration. A hemoglobin of 5.2 is associated with a plasma erythropoietin concentration sufficient to increase $\mathrm{Fe}^{59}$ incorporation sixfold in the case of hypoplastic anemia, while the plasma of a nephritic patient with a comparable anemia failed to demonstrate activity by the method employed. The bone marrow may be refractory to the stimulus produced by an increased erythropoietin content, as in Patient 5 with leukemia where no reticulocytes were present, while levels of erythropoietin sufficiently below the threshold of detection by this method may still be associated with a reticulocytosis, as in Patients 1,11 , and 18 .

We are led to postulate that patients with severe anemia have a high plasma titer of erythropoietin unless its production is decreased or its destruction or excretion is increased. In those instances where the patient will spontaneously correct the low hemoglobin levels, as following acute hemorrhage and drug-induced hemolytic anemia, we believe the elevated erythropoietin concentration will be found to decrease as the hemoglobin rises. The erythropoietin content may be expected to remain high in anemias which are not correctable by the unaided homeostatic body mechanisms, but will probably be found to decrease following blood transfusion to a normal level or following rise of hemoglobin to a normal level, as in pernicious anemia adequately treated with $\mathrm{B}_{12}$. Finally, we believe future work may indicate some anemias will be attributable to decreased or absent erythropoietin production. The recent investigation of Piliero and co-workers ${ }^{12}$ suggests primary red cell anemia of children may be such a disease. Since cobalt appears to act by increasing the production of erythropoietin, ${ }^{23}$ it is reasonable to anticipate anemias associated with renal disease, chronic infection, neoplasm, and rheumatoid arthritis, all re- 
sponsive to cobalt administration ${ }^{24-28}$ may be attributed to low plasma erythropoietin concentrations and may, therefore, respond to erythropoietin when a preparation sufficiently potent and pure enough to permit clinical trials becomes available. The decreased rate of iron incorporated in the red cells of starved rats and the response in these animals to anemic rat plasma ${ }^{17}$ suggest anemias accompanying starvation and cachectic states may be at least partially the result of low plasma erythropoietic concentrations.

\section{SUMMARY}

1. Using the incorporation of $\mathrm{Fe}^{59}$ into erythrocytes of hypophysectomized or starved male Sprague-Dawley rats, erythropoietin has been demonstrated in normal plasma. This required tenfold concentration when plasma extracts are prepared by heat denaturization or perchloric acid precipitation.

2. Without concentrating the plasma extracts, erythropoietin has been demonstrated in heat-denatured plasma extracts of 10 anemic subjects.

3. Hypoplastic anemia, in 3 patients, cannot be attributed to decreased erythropoietin concentration.

4. High erythropoietin concentrations in the blood of one patient with hypoplastic anemia fell promptly following blood transfusion.

5. Failure to demonstrate activity by this method is not necessarily indicative of decreased erythropoietin concentrations.

6. The results of this study are consistent with the hypothesis, first formulated by Carnot and Deflandre in 1906, that the rate of erythropoiesis is mediated by a humoral mechanism.

\section{LITERATURE CITED}

1. Carnot, P. and C. Deflandre. Compt. rend. Acad. sc. 143:384, 1906.

2. Grant, W. C. and W. S. Root. Physiol. Rev. 32:449, 1952.

3. Bonsdorff, E. and E. Jalavisto. Acta physiol. scandinav. 16:150, 1948.

4. Borsook, H., A. Graybiel, G. Keighley, and E. Windsor. Blood, 9:734, 1954.

5. Erslev, A. Blood, 8:349, 1953.

6. Erslev, A., P. H. Lavietes, and G. van Wagenen. Proc. Soc. Exp. Biol. Med., 83:548, 1953.

7. Gordon, A. S., S. J. Piliero, W. Kleinberg, and H. H. Freedman. Proc. Soc. Exp. Biol. Med., $86: 255,1954$.

8. Hodgson, G. and J. Toha. Blood, 9:299, 1954.

9. Gordon, A. S., S. J. Piliero, and M. Tannenbaum. Am. J. Physiol., 181:3, 585, 1955.

10. Contopoulos, A. N., J. H. Lawrence, R. K. McCombs, and M. E. Simpson. Clin. Research Proc., 5:30, 1957. 
11. Linman, J. W. and F. H. Bethell. J. Lab Clin. Med., 49:113, 1957.

12. Piliero, S. J., P. T. Medici, B. Pansky, L. Luhby, and A. S. Gordon. Proc. Soc. Exp. Biol. Med., 93:302, 1956.

13. Plzak, L. F., W. Fried, L. O. Jacobson, and W. F. Bethard. J. Lab. Clin. Med., $46: 671,1955$.

14. Gordon, A. S., S. J. Piliero, M. Tannenbaum, and C. D. Siegel. Proc. Soc. Exp. Biol. Med, $39 ; 246,1955$.

15. Jacobson, L. O., L. Plzak, W. Fried, and E. Goldwasser. Nature, 177:1240, 1956.

16. Fried, W., L. F. Plzak, L: O. Jacobson, and E. Goldwasser. Proc. Soc. Exp. Biol. Med., 92:203, 1956.

17. Fried, W., L. F. Plzak, L. O. Jacobson, and E. Goldwasser. Proc. Soc. Exp. Biol. Med., $94: 237,1957$.

18. Hahn, P. F., W. F. Bale, R. P. Hettig, and G. H. Whipple. Science, 92:131, 1940.

19. Goldwasser, E., C. W: Gurney, and L. O. Jacobson. Unpublished data.

20. Prentiss, T. C. and E. A. Mirand. Clin. Research Proc., 5:90, 1957.

21. Bethard, W. F. and R. Wissler. Personal communication.

22. Jacobson, L. O., E. Goldwasser, W. Fried, and L. F. Plzak. Nature, 179:633, 1957.

23. Goldwasșer, E., L. O. Jacobson, W. Fried, and L. Plzak. Science, 125:1085, 1957.

24. Robinson, J. C., G. W. James, III, and R. M. Kark. New England J. Med., 240:749, 1949.

25. Berk, L., J. H. Burchenal, and W. B. Castle. New England J. Med., 240:754, 1949.

26. Shen, S. C. and F. Hamburger. J. Lab. Clin. Med., 37:182, 1951.

27. Gardner, F. H. J. Lab. Clin. Med., 41:56, 1953.

28. Weinsaft, P. O. and L. H. T. Bernstein. Am. J. Med. Sc., 230:264, 1955.

Paper appeared subsequently as follows: Bethard, W. F., R. W. Wissler., J. S. Thompson, M. A. Schroeder, and M. J. Robson. Blood, 8:146, 1958 


\section{STUDIES ON ERYTHROPOIESIS. VII. THE ROLE OF THE KIDNEY IN THE PRODUCTION OF ERYTHROPOIETIN ${ }^{*}$}

\section{By}

L. O. Jacobson, E. Goldwasser, W. Fried, and L. F. Plzak

Many extirpation procedures that would have been desirable to use for study of the site of formation of erythropoietin could not, in the past, be applied because of the relatively long time required to produce measurable titers of erythropoietin and because of the short life span of the animals deprived of vital organs (or because of rapid regeneration in the case of the liver). After the observation that the administration of cobaltous ion or a single massive hemorrhage increases the plasma erythropoietin titers in rats and rabbits within 12 hours, ${ }^{1}$ it became possible to study the effect of such procedures as nephrectomy, evisceration, and hepatectomy upon erythropoiesis.

The association of anemia of varying severity with chronic renal disease is an old observation. ${ }^{2}$ Attempts have been made to determine the actual cause or causes of the anemia associated with renal disease or bilateral nephrectomy. ${ }^{3,4}$ The etiology has been ascribed to reduced erythropoiesis and hemolysis, ${ }^{5}$ but the mechanisms by which these come about have not been elucidated except to implicate the "toxicity" associated with uremia.

In the studies reported below we have used animals that were nephrectomized or had their ureters ligated and have determined their capacity to produce erythropoietin as a response to a single injection of cobaltous chloride, to chronic bleeding, or to a single massive bleeding. In a brief communication ${ }^{6}$ we reported that bilateral nephrectomy of rats and rabbits eliminated any measurable response to these stimuli, while ligating both ureters reduced but did not eliminate the capacity of the animals to produce an increased plasma level of erythropoietin. Details of these experiments and further observations on the role of the kidney in erythropoiesis are described in this report.

\section{EXPERIMENTAL PROCEDURE AND RESULTS}

Two sets of experiments are described in this paper. In the first set, the effect of bilateral nephrectomy or bilateral ureter ligation on the capacity of the rabbit to produce erythropoietin was studied. Plasma extract assays were carried out on polycythemic mice: In the second set of experiments, similar studies were performed on the rat, and the assays were performed on starved rats.

Rabbit plasma extract experiments. Young adult Swift snuffle-free rabbits with an average body weight of about $2.5 \mathrm{~kg}$ served as plasma donors under the various experi-

* Reprinted from the Transactions of the Association of American Physicians, 19:30517,1957 . 
mental conditions.

Nephrectomy experiments using bleeding as stimulus for erythropoietin production. In the previous study referred to in the introduction, ${ }^{6}$ it was found that when rats and rabbits were subjected to single massive bleeding just after bilateral nephrectomy, the plasma erythropoietin titer did not rise above the normal range. Since it had been demonstrated previously that chronic hemorrhage maintains a high plasma erythropoietin titer in animals, ${ }^{7}$ it seemed desirable to study the capacity of such anemic animals to maintain a high erythropoietin titer after bilateral nephrectomy or ureter ligation. Rabbits were therefore bled via cardiac puncture to induce an anemia (hematocrit less than 25 per cent). The schedule of bleedings employed regularly has been described elsewhere. $8,9,10$ On the day after the third bleeding, bilateral nephrectomy or ureter ligation was performed. The plasma for assay was collected 23 hours postoperatively. Control plasma consisted of anemic plasma and normal plasma. The types of plasma used and the conditions under which the collections were made are outlined in Table 1.

Table 1

CONDITIONS OF COLLECTION OF RABBIT PLASMA IN NEPHRECTOMY EXPERIMENTS*

\begin{tabular}{|c|c|}
\hline $\begin{array}{l}\text { Designation of } \\
\text { Plasma Preparation }\end{array}$ & Conditions of Collection \\
\hline 1. Cobalt plasma & $\begin{array}{l}\text { Cobaltous chloride-treated animals }(250 \mu \mathrm{M} / \mathrm{kg} \\
\text { subcutaneously). Blood collected } 10 \text { to } 12 \text { hours } \\
\text { after cobalt ion injection. }\end{array}$ \\
\hline 2. Nephrectomy-Cobalt & $\begin{array}{l}\text { Bilateral nephrectomy followed immediately by } \\
\text { subcutaneous injection of cobalt ion }(250 \mu \mathrm{M} / \mathrm{kg}) \text {, } \\
\text { Blood collected } 10 \text { to } 12 \text { hours after cobalt injec- } \\
\text { tion. }\end{array}$ \\
\hline 3. Nephrectomy-Normal & $\begin{array}{l}\text { Bilateral nephrectomy performed on normal animals. } \\
\text { Blood for assay collected } 12 \text { to } 24 \text { hours later. }\end{array}$ \\
\hline 4. Normal plasma & $\begin{array}{l}\text { Blood removed for assay by cardiac puncture from } \\
\text { previously untreated animals. }\end{array}$ \\
\hline 5. Anemic nephrectomy & $\begin{array}{l}\text { Animals made anemic by standard bleeding proce- } \\
\text { dure. } 8 \text { Bilateral nephrectomy performed on ane- } \\
\text { mic animals. Blood for assay withdrawn } 23 \text { hours } \\
\text { after nephrectomy. }\end{array}$ \\
\hline 6. Anemic-Ureters tied & $\begin{array}{l}\text { Animals made anemic by standard procedure. } 8 \text { Bi- } \\
\text { lateral ureter ligation performed on anemic ani- } \\
\text { mals. Blood for assay withdrawn } 23 \text { hours later. }\end{array}$ \\
\hline 7. Anemic plasma & $\begin{array}{l}\text { Animals made anemic over a period of several days } \\
\text { by standard procedure. } 8 \text { Blood then drawn for as - } \\
\text { say. }\end{array}$ \\
\hline
\end{tabular}

* Plasma processed before assay by perchloric acid precipitation method. Final preparation represented a threefold concentration of original plasma. 
Nephrectomy experiments using cobaltous ion as the stimulus. Immediately after bilateral nephrectomy, $250 \mu \mathrm{M} / \mathrm{kg}$ of cobaltous chloride was administered subcutaneously to rabbits. Ten to 12 hours later, the plasma for assay was collected. Control plasma consisted of plasma obtained from normal rabbits 10 to 12 hours after a single dose of 250 $\mu \mathrm{M} / \mathrm{kg}$ of cobaltous chloride and plasma from nephrectomized rabbits obtained at 10 to 24 hours after surgery (Table 1 ).

These plasma preparations were then processed by the following procedure: To plasma in an ice bath was added slowly, with stirring, an equal volume of cold 10 per cent perchloric acid. The resulting precipitate was removed by filtration and washed three times by stirring with an equal volume of 5 per cent perchloric acid. The pooled filtrates were dialyzed overnight against running tap water, after which the extract was at $\mathrm{pH} 5$ or higher. Dialysis was continued in the cold against several changes of distilled water, and the extract was then concentrated in a rotary evapuralor to $1 / 10$ of the original volume of the plasma. The plasma extract was stored at $-18^{\circ} \mathrm{C}$ until used and then was made 0.9 per cent with respect to sodium chloride before injection. The final preparation used for study was a threefold concentration in comparison with the original plasma.

The assay of the plasma extracts was carried out in mice with a transfusion-induced polycythemia. This assay technique has been described in detail. ${ }^{10}$

The mice were divided into groups of 8 animals each. The administration of the plasma extract was begun on the same day that homologous red cells were given intraperitoneally. The red cell injections were given daily for 3 days, then as frequently as necessary thereafter, usually every other day, to maintain a hematocrit of 70 per cent or more. The plasma extracts were given intraperitoneally in $0.5 \mathrm{cc}$ amounts each day for 9 days. The presence of reticulocytes in the peripheral blood of the animals was determined by means of the brilliant cresyl blue staining technique. The reticulocytes in a minimum of 1000 red cells were counted when their values reached 0.5 per cent or higher. When less than 0.5 per cent were found, the reticulocytes in 2 or more thousand red cells were counted.

As indicated in Figure 1, the reticulocyte values of the polycythemic mice, which received normal nephrectomy plasma or cobalt nephrectomy plasma, were at 0.0 per cent on the 9 th day. Those of the group that received cobalt plasma were approximately 1 per cent at this time.

In the animals that were bled prior to the operative procedure, only the group given anemic plasma extract and the one given plasma extract derived from anemic animals with bilateral ureter ligation had significantly elevated reticulocytes (Figure 2). These values were 1.0 and 1.4 per cent respectively. The reticulocyte values in the group that received anemic nephrectomy extract were 0.1 per cent. Those of the groups that received saline or normal plasma were less than 0.1 per cent.

Studies on whole rat plasma. Adult Sprague-Dawley rats of various weights were used exclusively. The effect of removal of various organs on the capacity of the rat to produce erythropoietin in response to a single injection of cobaltous chloride $(250 \mu \mathrm{M} / \mathrm{kg})$ was investigated. The whole plasma collected under the various conditions was assayed in 


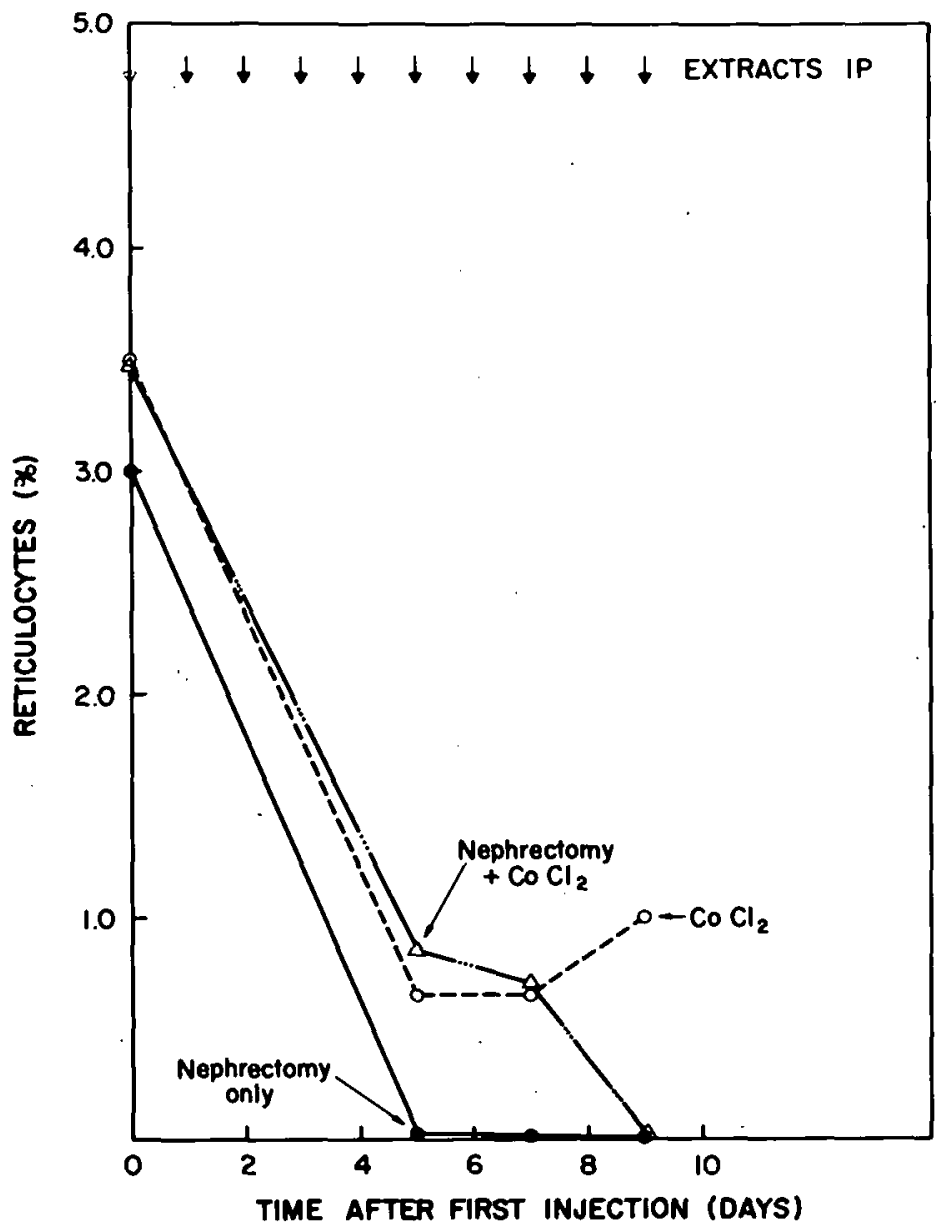

Figure 1. The effect of nephrectomy on the capacity of rabbits to produce erythropoietin. The effect of the injection of plasma extract prepared from rabbits given cobaltous chloride after bilateral nephrectomy upon the reticulocyte values of the peripheral blood of mice with transfusion polycythemia as compared with the effect of $\mathrm{Co}^{++}$plasma extract and nephrectomy plasma extract.

starved rats by a procedure described previously in detail. ${ }^{9}$ In all the studies reported below, a minimum of 4 to 6 rats was used in the assay of the individual plasma preparations. As can be seen in Table 2, removal of the adrenals and gonads; stomach, intestines, spleen and pancreas; thymus; or 90 per cent of the liver did not appreciably alter the responsiveness of the animal to production of erythropoietin after administration of cobalt. However, nephrectomy completely abolished such a response.

The study of animals with the excretory function of the kidney blocked and with the possible hormonal function undisturbed would be desirable to ascertain whether the uremia, resulting from the absence of the kidneys, could impair formation of erythropoietin by affecting a site distinct from the kidney. An approach to such a study was made by ligating both ureters of the rat. Twelve hours after such an operation, the resulting uremia 
Table 2

THE EFFECT OF PLASMA OBTAINED FROM RATS THAT HAD BEEN SUBJECTED TO ORGAN EXCISION AND THEN $\mathrm{CO}^{++}$STIMULATION UPON THE INCORPORATION OF $\mathrm{Fe}^{5 \mathfrak{g}}$ INTO THE RED BLOOD CELLS OF STARVED RECIPIENTS

\begin{tabular}{|c|c|c|c|}
\hline $\begin{array}{l}\text { Organ removed from } \\
\text { donor prior to } \\
\mathrm{Co}^{++} \text {injection }\end{array}$ & Stimulus & $\begin{array}{c}\text { Time of removal of blood from } \\
\text { donor after Co } \mathrm{Co}^{++} \text {injection } \\
\text { (Hours) }\end{array}$ & $\begin{array}{c}\text { Assay of donor plasma in starved rats } \\
\text { using } \% \mathrm{Fe} 5 \text { incorporation } \\
\text { Response of recipient to plasma preparation }\end{array}$ \\
\hline None & None & 12 & $3.7(0.4)^{\dagger}$ \\
\hline None & Cobalt $(250 \mu \mathrm{M} / \mathrm{kg})$ & 12 & $14.4(1.5)$ \\
\hline Adrenals and gonads & Cobalt & 12 . & $15.1(0.9)$ \\
\hline $90 \%$ of the liver & Cobalt & 12 & $12.4(0.4)$ \\
\hline $\begin{array}{l}\text { Stomach, intestines, } \\
\text { spleen, pancreas }\end{array}$ & Cobalt & 12 & $11.7(1.2)$ \\
\hline Kidneys & Cobalt & 12 & $4.5(0.7)$ \\
\hline None & None & 12 & $4.8(0.6)$ \\
\hline None & Cobalt & 12 & $16.5^{\ddagger}$ \\
\hline Thymus & Cobalt & 12 & $16.3(1.6)$ \\
\hline
\end{tabular}

*Immediately following the surgical procedure, the rats (Sprague-Dawley, $350 \mathrm{~g}$ ) were injected subcutaneously with cobaltous chloride, and 12 hrs. later the blood was collected via cardiac puncture. Plasma thus obtained was assayed in the starved rats by standard procedures. ${ }^{9}$

${ }^{+}$Standard error.

†Three rats. 


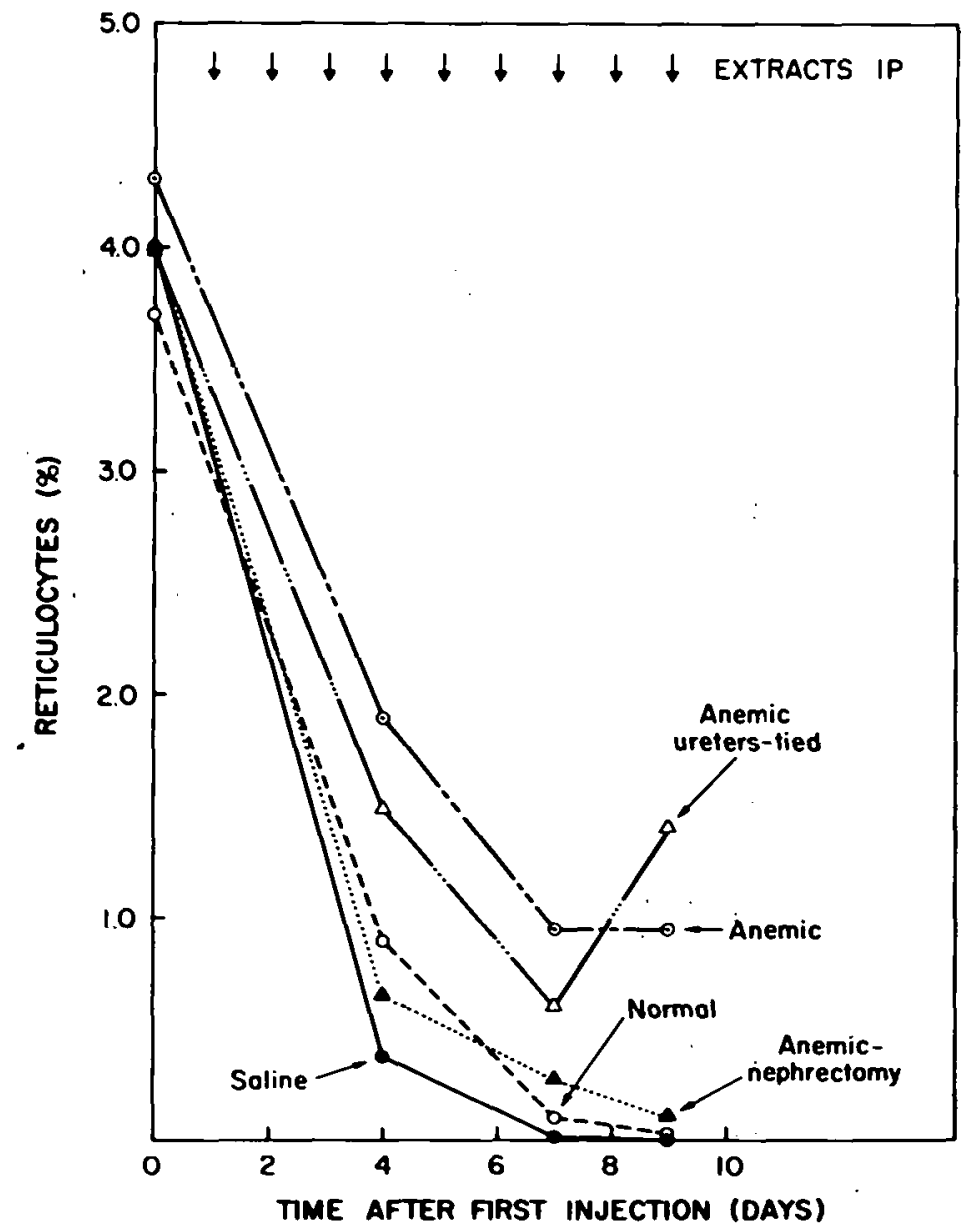

Figure 2. The effect of bilateral nephrectomy or ligation of the ureters on the capacity of anemic rabbits to maintain a high erythropoietin plasma titer. The effect of the injection of plasma extract prepared from the plasma of anemic rabbits subjected to bilateral nephrectomy or bilateral ureter ligation upon the reticulocyte values of the peripheral blood of mice with transfusion polycythemia as compared with the effect of plasma extract prepared from anemic plasma and normal plasma. Saline was utilized as an additional known negative control.

was comparable to that observed in bilaterally nephrectomized rats (Table 3 ). When such animals were given a dose of cobalt immediately after.operation, those with both ureters ligated were found to have plasma erythropoietin levels somewhat higher than those of the unoperated controls. The nephrectomized rats, however, had essentially no measurable plasma erythrópoietin.

Since cobalt is appreciably more toxic in the animal with ligated ureters than in the normal rat, the dose of cobalt used in this experiment $(167 \mu \mathrm{M} / \mathrm{kg}$ ) was smaller than that usually employed.

It is probable that the higher erythropoietin titer in the animals with ligated ureters 
Table 3

THE EFFECT OF PLASMA OBTAINED FROM RATS THAT HAD BEEN SUBIECTED TO NEPHRECTOMY OR LIGATION OF THE URETERS AND THEN $\mathrm{Co}^{++}$STIMULATION UPON THE INCORPORATION OF $\mathrm{Fe}^{59}$ INTO THE RED BLOOD CELLS OF STARVED RECIPIENTS

\begin{tabular}{|c|c|c|c|c|}
\hline$\underset{\text { procedure }}{\text { Surgical }}$ & Stimulus & $\begin{array}{c}\text { Time of removal of blood } \\
\text { from donor } \\
\text { after Co } \text { Co injection }^{++} \text {(Hours) }\end{array}$ & $\begin{array}{c}\text { BUN } \\
\text { of plasmat }\end{array}$ & $\begin{array}{c}\text { Assay of donor plasma in recip- } \\
\text { ient starved rats using } \% \mathrm{Fe}^{59} \\
\text { incorporation } \\
\text { Response of recipient to plasma } \\
\text { preparation }\end{array}$ \\
\hline None & None & -- & -- & $3.3(0.2)^{\ddagger}$ \\
\hline None . & Cobalt $(167 \mu \mathrm{M} / \mathrm{kg})$ & 12 & 22 & $6.6(1.1)$ \\
\hline Nephrectomy & Cobalt & 12 & 99 & $3.3(0.5)$ \\
\hline Ligation of the ureters & Cobalt & 12 & 95 & $9.8(0.1)$ \\
\hline
\end{tabular}

*Immediately following the surgical procedure, the rats (Sprague-Dawley, 350 g) were injected subcutaneously with cobaltous chloride, and 12 hrs. later the blood was collected via cardiac puncture. The plasma thus obtained was assayed in starved rats by standard procedures.

${ }^{+}$Blood urea nitrogen.

† Standard error 
as compared with unoperated rats is due to the fact that cobalt is excreted rapidly by the kidney and, in the absence of an excretory mechanism, the plasma levels are kept higher than those in normal animals, resulting in a more prolonged stimulus.

When the uremia was well-established, e.g., 24 hours after ligation of the ureters, the capacity of the animal to produce erythropoietin was reduced though not abolished. 6

When the stimulus for the production of erythropoietin is a single bleeding rather than an injection of cobaltous chloride, the same situation obtains: nephrectomy abolishes the response, while ligation of the ureters does not interfere with it until a time long enough for the "toxic effects of the uremia" to be apparent (Table 4).

If the kidneys of previously stimulated animals are removed at varying times after the administration of cobalt, the production of erythropoietin "ceases". and the level in the plasma declines at a rate not markedly different from that seen in the unoperated animal. Figure 3 demonstrates this and also shows that one kidney is sufficient to give a normal

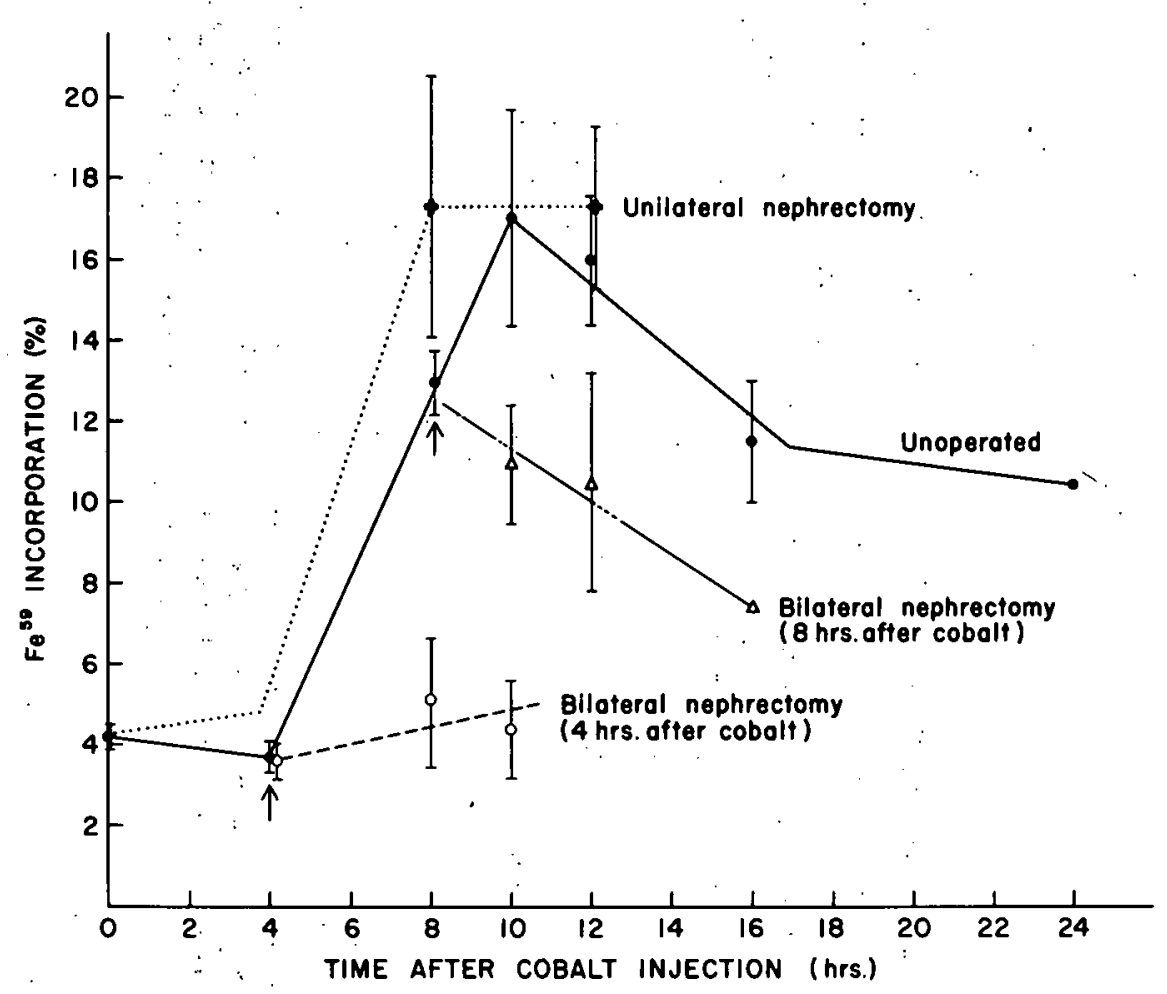

Figure 3. The effect of plasma obtained from rats that had been subjected to nephrectomy and cobalt stimulation on the incorporation of $\mathrm{Fe}^{59}$ into the red blood cells of starved recipients. SpragueDawley rats, weighing $350 \mathrm{~g}$, were used as donors. The se were injected with $75 \mu \mathrm{M}$ of $\mathrm{CoCl}_{2}$ at zero time, nephrectomy was performed at intervals indicated by arrows, and exsanguination at times indicated by points. The plasma was. assayed in starved rats, using the per cent of $\mathrm{Fe}^{59}$ incorporation. Each point represents the average per cent of $\mathrm{Fe}^{59}$ incorporation into the red blood cells of 5 rats. The standard deviations are given. 
Table 4

THE EFFECT OF TIME AFTER NEPHRECTOMY OR URETER LIGATION ON THE.FORMATION OF ERYTHROPOIETIN IN RESPONSE TO A SINGLE BLEEDING

\begin{tabular}{l|l|c|c}
\hline $\begin{array}{c}\text { Surgical } \\
\text { procedure }\end{array}$ & Stimulus & $\begin{array}{c}\text { Time of removal of blood from } \\
\text { donor rat after a single bleeding } \\
\text { (Hours) }\end{array}$ & $\begin{array}{c}\text { Assay of donor plasma in recipient starved } \\
\text { rats using \% Fe } 59 \text { incorporation } \\
\text { Response of recipient to plasma preparation }\end{array}$ \\
\hline None & None & -- & $4.6(0.2)^{\dagger}$ \\
None & Bleeding & 8 & $9.6(0.9)$ \\
Nephrectomy & Bleeding & 8 & $4.2(0.5)$ \\
Nephrectomy & Bleeding & 18 & $4.1(0.2)$ \\
Nephrectomy & Bleeding & 24 & $4.5(0.4)$ \\
Ligation of the ureters & Bleeding & 8 & $8.0(0.5)$ \\
Ligation of the ureters & Bleeding & 18 & $8.5(0.5)$ \\
Ligation of the ureters & Bleeding & 24 & $5.7(0.2)$ \\
\hline
\end{tabular}

Immediately following surgery, the rats (Sprague-Dawley, $350 \mathrm{~g}$ ) were bled by cardiac puncture. Seven ml of blood were withdrawn. A hematocrit of 27 to 30 per cent was attained. At the intervals indicated above after the bleeding, the donor rats were exsanguinated, and the plasma was assayed in starved rats by a standard procedure. ${ }^{9}$

${ }^{+}$Standard error. 
response to cobalt. If the kidney is removed before any erythropoietin is detectable in the plasma, the titer does not rise appreciably. This is an indication that the observed lag period after the injection of cobalt is not a reflection of the liberation from the kidney of an active precursor that is activated subsequently.

\section{COMMENT}

The evidence obtained by our means of assay indicates that the capacity of rats and rabbits to increase their production of erythropoietin(s) in response to a single dose of cobaltous chloride, or to a single massive hemorrhage is abolished by bilateral nephrectomy. This capacity is a reproducible characteristic of the normal rat or rabbit. In rats or rabbits in which the plasma erythropoietin titer is elevated by repeated hemorrhage or a single injection of cobalt ion, bilateral nephrectomy reduces the titer to the normal range within 24 hours. On the other hand, tying off both ureters may reduce the capacity to respond to cobalt ion or bleeding but does not abolish it, even though, as we have shown, the degree of uremia in the animals with the ureters tied off may be at a comparable lev el or higher than that in the nephrectomized animals. Our evidence also indicates that the capacity of animals with bilateral ureter ligation to produce erythropoietin in response to cobalt or bleeding is greater at 12 hours than at 24 hours after surgery. This indicates either that a deterioration of erythropoietin production in the kidney (or elsewhere) occurs as a result of the toxicity of the increasing state of uremia or that erythropoietin production is being reduced as a result of local renal effects, perhaps mechanical.

Several important aspects of this problem must be emphasized. In the first place, since the chemical identity of erythropoietin(s) is unknown, any assay procedure, whether performed on the normal animal or upon special preparations (hypophysectomized, starved, polycythemic rat, polycythemic mouse), and whether the response is measured by the uptake of $\mathrm{Fe}^{59}$, changes in blood volume, the number of reticulocytes, or histologic observation,'is purely qualitative. We cannot state with certainty that a negative response obtained by the use of any of these methods of assay indicates the absence of erythropoietin(s) from the plasma or plasma extracts that are being investigated. It is possible that after nephrectomy the donor animals fail to respond to the usual stimulus $\left(\mathrm{Co}^{++}\right.$, bleeding, or phenylhydrazine) by an increased production but may produce a normal or a reduced amount of erythropoietin. In either event, we would fail to find evidence of activity by testing with whole plasma. In the experiments on rabbits, we used extracts representing threefold plasma concentrations and obtained no evidence of increased erythropoietin activity in the plasma of nephrectomized animals that had been subjected to bleeding or $\mathrm{Co}^{++}$.

Yet another possibility has been examined in an attempt to explain the negative results we have obtained after nephrectomy. One might take the point of view that bilateral nephrectomy eliminates from the circulation an organ through which perhaps as much as 10 to 30 per cent of the circulating arterial blood passes. Bilateral nephrectomy, in effect, shunts this fully oxyge nated blood back to the general circulation. One 'might suggest, therefore; that the nephrectomized animal is relatively polycythemic and that the oxygen 
supply to the animal as a whole is increased. If this were true, it might be expected that the production of erythropoietin would be reduced. To test this, we have bled animals, reducing their hematocrits to less than 25 per cent. Under these experimental conditions, the erythropoietin titer was high. When bilateral nephrectomy was performed in these animals and the anemia was maintained, the erythropoietin titer fell to control levels. In addition, we have surgically removed other tissues or combinations of tissues ( 90 per cent of the liver or evisceration) that might be expected to produce a "relative polycythemia" comparable to bilateral nephrectomy. These animals responded to cobalt ion or bleeding with an elevation of erythropoietin. It may be necessary, however, to reduce more drastically the available oxygen by exposure of the animal to a low oxygen tension to explore fully this possibility. We have not as yet done this experiment.

Another possibility referred to previously ${ }^{6}$ is that the toxic condition resulting from bilateral nephrectomy is qualitatively different from that of the uremia that follows tying off both ureters. There is the likelihood that the "toxicity" following bilateral nephrectomy under the experimental conditions described interferes with the action of cobalt at some site other than the kidney; whereas the bleeding and phenylhydrazine technique is not sufficiently drastic to overcome the effect of the "increased oxygen supply" referred to above. In addition, the site of erythropoietin formation may be affected by the toxic agent(s).

The possibility that the kidney is only one important link in the manufacture of erythropoietin must also be borne in mind. ${ }^{6}$.The chance that an organ or tissue other than the kidney may produce an inactive precursor in response to cobalt ion or anemia that is activated in the kidney seems unlikely since the regular assay procedures employ animals with intact kidneys. It is also possible that a precursor originating in some tissue other than the kidney can be activated only by an anoxic kidney. Yet another possibility is that the kidney makes an inactive precursor that is activated elsewhere in the body. If this were the case; then animals with bilateral nephrectomy would not be expected to respond to the stimulus of cobalt ion; bleeding, phenylhydrazine, or other stimuli unless another secondary site of production existed.

For the reasons stated above, it would be premature at this time to correlate these findings with the frequently reported relationship of renal disease to anemia. If further work in this field makes quantitative measurement of erythropoietin activity possible, we will be in a much better position to determine whether the kidney is the sole producer of erythropoietin(s), is a co-producer, or is not involved at all, and that our experimental approach has succeeded only in further clouding the situation.

\section{SUMMARY AND CONCLUSIONS}

Our experiments indicate that bilateral nephrectomy eliminates the normal capacity of rabbits and rats to elevate the circulating erythropoietin titer in response to the stimuli of anemia or the injection of cobaltous chloride. Bilateral ureter ligation reduces but does not eliminate this capacity to respond even though the degree of uremia under both experimental conditions may be comparable. However, this capacity to produce erythro- 
pioetin is greater 12 hours after bilateral ureter ligation than at 24 hours, indicating that the toxemia of the uremia may actually suppress the production of erythropoietin. Exclsion of other organs or tissues, including the thymus, spleen, stomach and intestines, adrenals, pancreas, gonads, and 90 per cent of the liver does not eliminate the capacity of animals to respond to bleeding or cobalt ion.

Possible alternative explanations for our data are presented.

LI'EKATUKE CITED

1. Goldwasser, E., L. O. Jacobson, W. Fried, and .L. Plzak. Science, 125:1085, 1957.

2. Galen, I. R. and L. R. Limarzi. Am. J. Chin. Path.; 20:3, 1950.

3. Muirhead, E. E., F. Jones, and A. Grollman. J. Lab. Cling. Med., 39:505, 1952.

4. Emerson, C. P. Blood, 3:363, 1948.

5. Emerson, C. P., Jr. and B. A. Burrows. J. Chin. Invest., 28:779, 1949.

6. Jacobson, L. 'O., E. Goldwasser, W. Fried, and L. Plzak. Nature, 179:633, 1957.

7. Erslev, A. J. Blood, 10:954, 1955.

8. Fried, W., L. Plzak, L. O. Jacobson, and E. Goldwasser. Próc. Soc. Exp. Biol. and Med., 92:203, 1956.

9. Fried, W., L. F. Plzak, L. O. Jacobson, and E. Goldwasser. Proc. Soc. Exp. Biol. and Med., 94:237, 1957.

10. Jacobson, L. O., E. Goldwasser, L. F. Plzak, and W. Fried. Proc. Soc. Exp. Biol. and Med., 94:243, 1957.

63 
STUDIES ON ERYTHROPOIESIS. VIII. THE EFFECT OF NEPHRECTOMY ON RESPONSE TO HYPOXIC ANOXIA *

By

E. Goldwasser, W. Fried, and L. O. Jacobson

The existence of one or more humoral factors involved in the regulation of erythropoiesis has become accepted quite widely, and that factor which is formed in the animal in response to an anemic stress has been termed hemopoietine ${ }^{1}$ or erythropoietin. ${ }^{2}$. The site of production of erythropoietin is still not established unequivocally. Gordon and his co-workers ${ }^{3}$ have demonstrated that extracts of a variety of organs from anemic animals are devoid of erythropoietic activity. Previously, it had been shown that hematopoietic tissues (radio- and nitrogen mustard-sensitive) were not involved in elaboration of erythropoietin. ${ }^{4-6}$ Hypophysectomized animals have also been shown to respond to hemorrhage ${ }^{7-9}$ ruling out the pituitary as a source of the plasma factor. We have shown that removal of the kidneys of experimental animals was followed by loss of the capacity to respond to hemorrhage or to cobaltous ion, by an increase in circulating erythropoietin while removal of other organs had no such effect. ${ }^{10,11}$ Exactly proper controls for experiments such as these are admittedly quite difficult to obtain, but in controls which were made comparably uremic by tying off both ureters, there was impairment of response only after a relatively long time, while at short times there was no inhibition of production of erythropoietin. Because of these findings we suggested that the kidney is involved in production of erythropoietin.

Recently, a paper ${ }^{12}$ appeared in which nephrectomized animals were reported to respond to hypoxic anoxia about as well as intact animals, and the suggestion was made that there might be different sources of different erythropoietins, depending on the nature of the stimulus. In this paper we will demonstrate that the situation regarding the role of the kidney is the same whether the stress is hemorrhage or cobalt, as previously reported, or hypoxia at reduced pressure or hypoxia at atmospheric pressure.

\section{METHODS}

Male, Sprague-Dawley rats (300-350 g) were used as donors of plasma: Bilateral nephrectomy and bilateral ureter ligation were performed via a single abdominal incision. The ureters were ligated within $1 \mathrm{~cm}$ of the renal pelvis and cut distally. At various intervals following operation, the rats were placed into a hypoxic atmosphere for varying lengths of time. Hypoxic anoxia was induced by exposing the rats to either a simulated altitude of 21,500 feet in a low pressure chamber, or to an environment containing $9 \%$ oxy-

\footnotetext{
*Reprinted from the Journal of Laboratory and Clinical Medicine, 52:375-78, 1958.
} 
gen at atmospheric pressure at a flow rate of $510 \mathrm{~L} / \mathrm{hr}$. The rats were bled by cardiac puncture immediately after they were removed from the chamber. The heparinized plasma was collected, pooled, and bioassayed by methods reported previously ${ }^{8,13}$ to determine erythropoietin titèrs. In experiments in which hypophysectomized rats were used, they were purchased from Hormone Assay Laboratories, Chicago. The results are expressed as per cent of total radioiron injected, incorporated into red cells at 20 hour.s. Each figure usually represents the average of values for 5 rats.

\section{RESULTS AND DISCUSSION}

Because of the discrepancy between our first findings with hypoxia and those in the literature, ${ }^{12}$ we repeated the same experiment, with only minor modifications, eight times. The results of these experiments are summarized in Table 1. In each, the nephrectomized rats subjected to a simulated altitude of $21,500 \mathrm{ft}$. did not produce a significant plasma erythropoietin titer. The plasma erythropoietin titer from these animals was as low as that from control rats not placed in the chamber. This was true whether the time of ex-

Table 1

EFFECT OF NEPHRECTOMY AND URETER LIGATION ON RESPONSE OF RATS TO HIGH ALTITUDE HYPOXIA

\begin{tabular}{c|c|r|c|c|c|}
\hline \multirow{2}{*}{ Experiment } & $\begin{array}{c}\text { Hours at } 21,500 \\
\text { ft. simulated } \\
\text { altitude }\end{array}$ & \multicolumn{5}{|c|}{$\% \mathrm{Fe}^{59}$ Incorporation } \\
\cline { 3 - 6 } & 8 & $13.2(3.1)$ & $10.0(1.4)$ & $6.9^{\dagger}$ & $4.9(2.4)$ \\
1 & 8 Unoperated & Ureter-ligated & Nephrectomized & $\begin{array}{c}\text { Normal } \\
\text { plasma }\end{array}$ \\
2 & 8 & $9.2(0.6)$ & $5.1(0.7)$ & $2.5(0.5)$ & $2.1(0.7)$ \\
$3 *$ & 8 & $18.8(1.8)$ & $15.5(3.1)$ & $7.3(1.1)$ & $7.7(1.7)$ \\
4 & 8 & $11.5(1.9)$ & $9.8(1.9)$ & $4.3(1.0)$ & $4.6(2.0)$ \\
5 & 8 & $10.9(1.6)$ & $9.1(1.5)$ & $5.8(1.3)$ & $4.9(0.2)$ \\
6 & 10 & $8.5(1.2)$ & $8.0(1.3)$ & $4.4(0.5)$ & $3.7(0.2)$ \\
7 & 16 & $8.6(2.3)$ & $9.6(2.5)$ & $4.5(2.0)$ & $5.9(1.6)$ \\
8 & 24 & $14.7(2.6)$ & $14.6(2.7)$ & $4.7(1.6)$ & $3.9(0.6)$ \\
9 & 24 & $17.0^{\dagger}$ & $11.0(2.2)$ & $3.6(0.9)$ & $3.8(0.9)$ \\
\hline
\end{tabular}

Plasma from unoperated, ureter-ligated, and nephrectomized animals obtained from rats after removal from high altitude chamber, normal plasma from unstimulated rats. Assays performed in starved rats. Five rats used per assay group. Figures in parentheses are standard error of the mean.

* Assay rats in experiment 3 , fasted one day less than usual procedure.

$t_{\text {Three rats per group. }}$

"We are greatly indebted to Dr. John Doull for his help with, and the use of, the low pressure chamber and to Dr. Eric Simmons for help in construction of the low $\mathrm{O}_{2}$ chamber. 
posure to the high altitude was $8,10,16$, or 24 hours. In every experiment except \#2, the rats whose ureters were ligated before stimulation produced amounts of erythropoietin similar to those produced by unoperated rats in response to the high altitude anoxia. The degree of uremia in the ureter-ligated rats, as determined by blood urea nitrogen at each interval, was comparable to that in the nephrectomized rats. If the iron incorporation data are calculated as per cent of that given by plasma from unoperated stimulated animals and the whole series of experiments are averaged, the results may be expressed as follows: unoperated 100, normal plasma 38, ureter-ligated 81, and nephrectomized 41 .

These results demonstrate quite clearly that the nephrectomized rat loses its capacity to increase erythropoietin in response to hypoxic anoxia as well as to hemorrhage or cobalt.

In order to study further the effect of uremia on the capacity of rats to produce erythropoietin in response to a low $\mathrm{O}_{2}$ atmosphere, we performed bilateral nephrectomy and ureter ligation in groups of rats immediately prior to, 4 hours before, and 16 hours before placing them in the high altitude chamber. In all cases, nephrectomy again abolished response to the stimulus. In the animals with ureters tied off immediately before and 4 hours before stimulating for 16 hours, the response was of about the same magnitude as that shown by unoperated animals. If, however, the ureters were tied off 16 hours before stimulus, the response was diminished but still appreciable (Table 2). It seems to us that this reduction in responsiveness of the animals with ligated ureters is quite likely due to mechanical injury to the kidney by the pressures built up there. At autopsy the kidneys from rats in which the ureters had been tied off appear about twice the normal size. Their uncut surfaces are pale, and on cutting perpendicular to the anterior-posterior axis, the cut surfaces are blanched, especially in the cortical region:

There still remained two possible explanations for the discrepancy between our results and those published previously. ${ }^{12}$ The earlier work on hypoxic anoxia reported by Prentice and Mirand ${ }^{12}$ was done at atmospheric pressure in a chamber containing a low partial pressure of oxygen, and the plasma was assayed in hypophysectomized rats rather than in starved rats as we had used. When we repeated our experiments using both of these conditions, we again found that nephrectomy completely abolished the response to low oxygen tension (Table 3). We found no difference qualitatively between the response of hypophysectomized and starved rats used as assay animals and no difference between low pressure hypoxia and atmospheric pressure hypoxia.

These findings have been corroborated using the polycythemic mouse for assay ${ }^{14}$ : and will be the subject of a forthcoming communication.

As of this writing, we do not know why the results obtained in the two different laboratories are so divergent, but we feel, in the light of the experiments reported here, that the suggestion of Prentice and Mirand of different erythropoietins being formed in response to different anoxic stimuli is untenable.

These experiments do not, of course, establish beyond doubt that the kidney produces erythropoietin. The possibility remains that the consequences of nephrectomy in some way 
Table 2

EFFECT OF UREMIA ON RESPONSE TO HIGH ALTITUDE HYPOXIA

\begin{tabular}{|c|c|c|c|c|c|c|c|c|}
\hline \multirow{2}{*}{$\begin{array}{l}\text { Hours between } \\
\text { operation and } \\
\text { start of stimulus }\end{array}$} & \multicolumn{8}{|c|}{$\% \mathrm{Fe}^{59}$ Incorporation } \\
\hline & Unoperated & BUN & Ureter ligated & BUN & Nephrectomized & BUN & Normal plasma & BUN \\
\hline 0 & $11.6(1.9)$ & 24 & $9.8(1.9)$ & 57 & $4.3 *$ & 59 & $4.6(1.1)$ & 24 \\
\hline 4 & -- & -- & $14.0(0.9)$ & 98 & $4.0(1.3)$ & 99 & -- & -- \\
\hline 16 & -- & -- & $7.2(1.9)$ & 130 & $5.0(1.0)$ & 134 & -- & -- \\
\hline
\end{tabular}

Unoperated, ureter-ligated, and nephrectomized rats at 21,500 ft. simulated altitude for 16 hours. Plasma obtained immediately after removal from chamber. Normal plasma from unstimulated rats. Assays performed in started rats; 5 rats per assay group. Figures in parentheses are standard error of the mean. BUN in $m g$ per cent.

* 3 rats in group.

Table 3

EFFECT OF NEPHRECTOMY ON RESPONSE TO HYPOXIA: COMPARISON OF LOW PRESSURE HYPOXIA WITH ATMOSPHERIC PRESSURE HYPOXIA AND OF STARVED RAT ASSAY WITH HYPOPHYSECTOMIZED RAT ASSAY

\begin{tabular}{c|l|c|c|c|c}
\hline \multirow{2}{*}{$\begin{array}{c}\text { Type of } \\
\text { hypoxic stimulus }\end{array}$} & \multicolumn{1}{|c}{ Assay rat } & \multicolumn{4}{|c}{$\% \mathrm{Fe}^{59}$ Incorporation } \\
\cline { 3 - 6 } & & Unoperated & Ureter ligated & Nephrectomized & Normal plasma \\
\hline Low pressure & Starved & $17.0 *$ & $11.0(1.9)$ & $3.6(0.4)$ & $3.8(0.4)$ \\
& Hypophysectomized & $17.8(3.5)$ & $10.0(0.8)$ & $4.5(0.2)$ & $2.0(0.5)$ \\
Atmospheric & & & & & \\
pressure. & Starved & $17.4(1.4)$ & $13.9(2.0)$ & $3.5(0.8)$ & $4.4(0.5)$ \\
& Hypophysectomized & $22.9(8.0)$ & $13.4(0.8)$ & $3.5(1.1)$ & $4.1(0.9)$ \\
\hline
\end{tabular}

Low pressure series kept at simulated altitude of $21,500 \mathrm{ft}$. (10\% oxygen) for $16 \mathrm{hrs}$; atmospheric pressure series kept in $9 \%$ oxygen for $16 \mathrm{hrs}$. Plasma obtained from rats immediately after removal from chamber. Normal plasma from unstimulated rats. Five rats per assay group. Figures in parentheses are standard error of the mean.

* 3 rats in group. 
interfere with elaboration of the hormone by another site or that plasma from nephrectomized animals contains substances which may interfere with the primary erythropoietic process. Experiments testing these possibilities are now under way.

\section{SUMMARY}

Rats subjected to hypoxic anoxia, whether at low pressure or atmospheric pressure, respond to this condition with an increase in plasma erythropoietin.

Ligation of ureters for relatively short times does not interfere with this response. Nephrectomy completely abolishes this response.

\section{LITERATURE CITED}

1. Carnot, P., and C. Deflandre. Compt. rend. Acad. sc., 143:384, 1906.

2. Bonsdorff, E., and E. Jalavisto. Acta physiol. scandinav., 16:150, 1948.

3. Gordon, A. S., S. J. Piliero; P. T. Medici, C. D. Siegel, and M. Tannenbaum. Proc. Soc. Exp. Biol. Med., 92:598, 1956.

4. Erslev, A. J., and F. H. Lavietes. Blood, 9:1055, 1954.

5. Stohlman, F., E. P. Cronkite, and G. Brecher. Proc. Soc. Exp. Biol. Med., 88:402, 1955.

6. Linman, J. W., and F. H. Bethell. Blood, 12:123, 1957 .

7. Gordon, A. S., S. J. Piliero, M. Tannenbaum, and C. D. Siegel. Proc. Soc. Exp. Biol. Med., 89:246-48, 1955.

8. Fried, W., L. Plzak, L. O. Jacobson, and E. Goldwasser. Proc. Soc. Exp. Biol. Med., $92: 203,1956$.

9. Crafts, R. C., and H. A. Meineke. Proc. Soc. Exp. Biol. Med., 92:222, 1956.

10. Jacobson, L. O., E. Goldwasser, W. Fried, and L. Plzak. Nature, 179,633, 1957.

11. Jacobson, L. O., E. Goldwasser, W. Fried, and L. F. Plzak. Trans. Assoc. Amer. Physicians, 70:305, 1957.

12. Mirand, E. A., and T. C. Prentice. Proc. Soc. Exp. Biol. Med., 96:49, 1957.

13. Fried, W., L. F. Plzak, L. O. Jacobson, and E. Goldwasser. Proc. Soc. Exp. Biol. Med., 94:237, 1957.

14. Jacobson, L. O., E. Goldwasser, L. F. Plzak, and W. Fried. Proc. Soc. Exp. Biol. Med., 94:243, 1957 . 


\title{
STUDIES ON ERYTHROPOIESIS. IX. MECHANISM OF DECREASED ERYTHROPOIESIS IN EXPERIMENTAL POLYCYTHEMIA *
}

By

\author{
C. W. Gurney and C. Pan
}

That increased erythropoiesis following production of acute anemia is mediated on a hormonal basis was first suggested by Carnot and Deflandre. ${ }^{1}$ In recent years, numerous investigators have demonstrated appearance of a humoral erythropoietic-stimulating factor in anemic animals. ${ }^{2-9}$ Fried, Plzak, Jacobson, and Goldwasser ${ }^{10}$ have presented evidence supporting the hypothesis that the rate of erythropoiesis is determined by amount of erythropoietin in plasma at all times. It has long been known that experimentally-induced polycythemia depresses erythropoiesis. ${ }^{11-15}$ That decreased concentrations of erythropoietin are responsible for depression of erythropoiesis in transfusion-induced polycythemia was first suggested by Fried et al. ${ }^{10}$ and Jacobson et al. ${ }^{16}$

Demonstration of decreased concentrations of erythropoietin in plasma of transfusioninduced plethoric animals and human beings is as important in establishing validity of the concept of a humoral control of erythropoiesis as is demonstration of increased erythropoietin concentrations in plasma obtained from anemic donors. In this paper, the decline in reticulocyte count and incorporation of $\mathrm{Fe}^{59}$ into newly-formed red cells of polycythemic rats, and degree of decline in relation to severity of polycythemia are reported. In addition, response of these polycythemic animals to anemic plasma and cobaltous chloride is described.

\section{METHODS ANDD MATERIALS}

Rats of the Sprague-Dawley strain were used in this study. Animals in last experiment were hypophysectomized by Hormone Assay Laboratories of Chicago. Blood was removed from donor animals by cardiac puncture, using heparin as anticoagulant. Intravenous transfusions consisted of whole blood or $50 \%$ red cells resuspended in saline. Intraperitoneal injections consisted of $80 \%$ red cells suspended in saline. In the last 3 experiments, periodic hemoglobin and reticulocyte counts were determined on blood obtained from tail vein. In all other studies, blood was obtained by cardiac aspiration at time of sacrifice. Hemoglobin values were determined by measurement of oxyhemoglobin as described by Evelyn. ${ }^{17}$ Reticulocytes were counted by direct smear method, using brilliant cresyl blue stain without counter-stain. Rate of erythropoiesis was then determined as follows: ${ }^{18} \mathrm{Fe}_{3}{ }^{59}$ citrate (1 to $2 \mu \mathrm{c}$ ) was injected into tail vein of animals, and 16 hours

\footnotetext{
*Reprinted from the Proceedings of the Society for Experimental Biology and Medicine, 98:789-93; 1958 .
} 
thereafter $1 \mathrm{ml}$ of blood was obtained by cardiac puncture. Standards were prepared at time the isotope was administered to animals. Activity of standards and the blood was determined by counting in a well-type scintillation counter. The amount of radioactivity in the entire circulating red cell mass was calculated by multiplying the activity per $\mathrm{ml}$ of blood by the blood volume and was expressed as per cent of injected dose of $\mathrm{Fe}^{59}$ in peripheral red cells. Blood volumes of rats with carying degrees of polycythemia were determined in preliminary experiments by the method of Berlin et al. ${ }^{19}$

Plasma referred to as "anemic" rat'plasma was obtained from rats whose hematocrit had been reduced to $25 \%$ by 3 daily cardiac aspirations. Human plasma was obtained from a normal donor and a donor with idiopathic aplastic anemia, using heparin as anticoagulant. Extracts of human plasma were prepared by the method of Borsook et al. ${ }^{20}$

Decrease of reticulocyte count and red cell incorporation of $\mathrm{Fe}^{59}$ following intraperitoneal injection of blood. Rats weighing 250-280 g were made polycythemic by a single intraperitoneal injection of packed cells equal to $4 \%$ body weight, and control animals were given the same volume of normal saline. Reticulocyte counts and red cell $\mathrm{Fe}^{59}$ incorporation were determined in separate groups of 5 animals at the times indicated in Figures 1 and 2. No change in reticulocyte count was noted 17 hours after administration of blood,

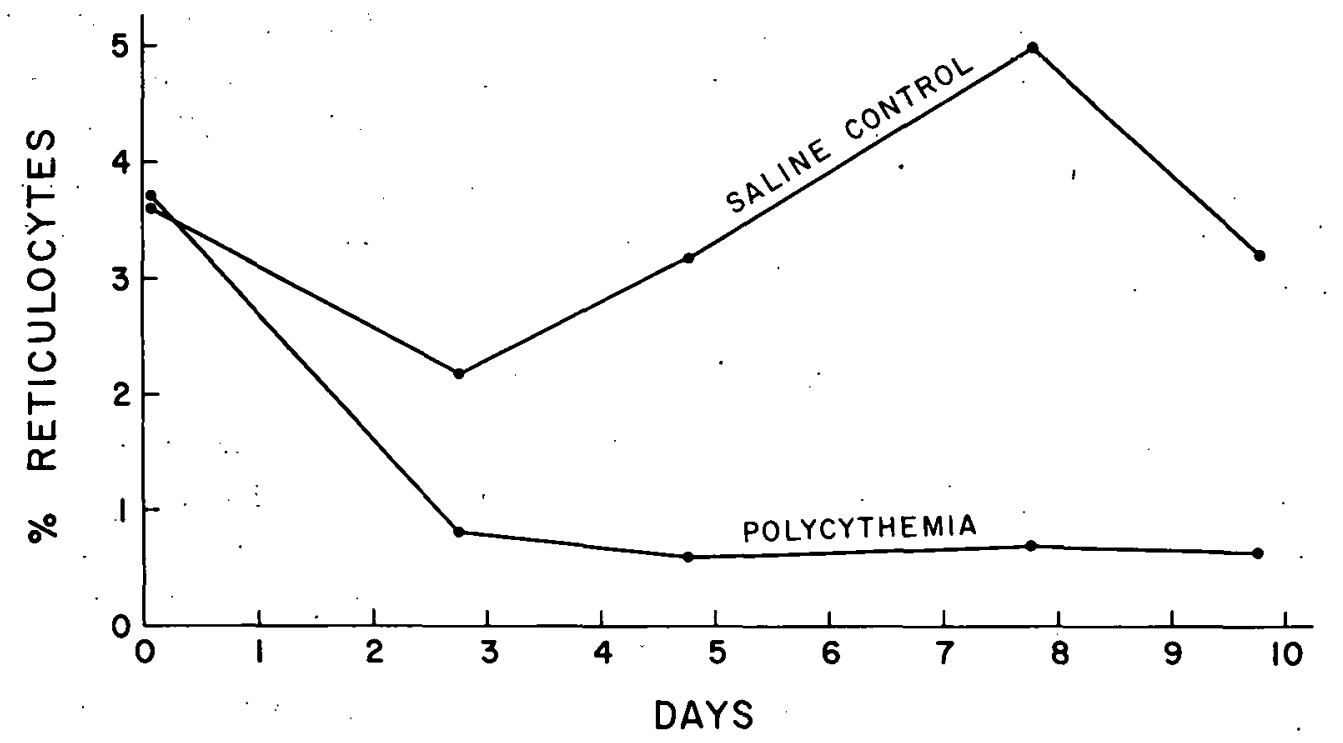

Figure 1. The effect of experimentally-induced polycythemia on the number of reticulocytes in the rat.

but at 2 days and thereafter a marked reduction in number of reticulocytes was noted (Figure 1). Similarly, incorporation of $\mathrm{Fe}^{59}$ was reduced at 4 days and fell steadily, reaching its low value of $5 \%$ when the tracer was given 9 days after the animals were made polycythemic (Figure 2).

Effect of varying degrees of polycythemia on number of reticulocytes and incorpora- 


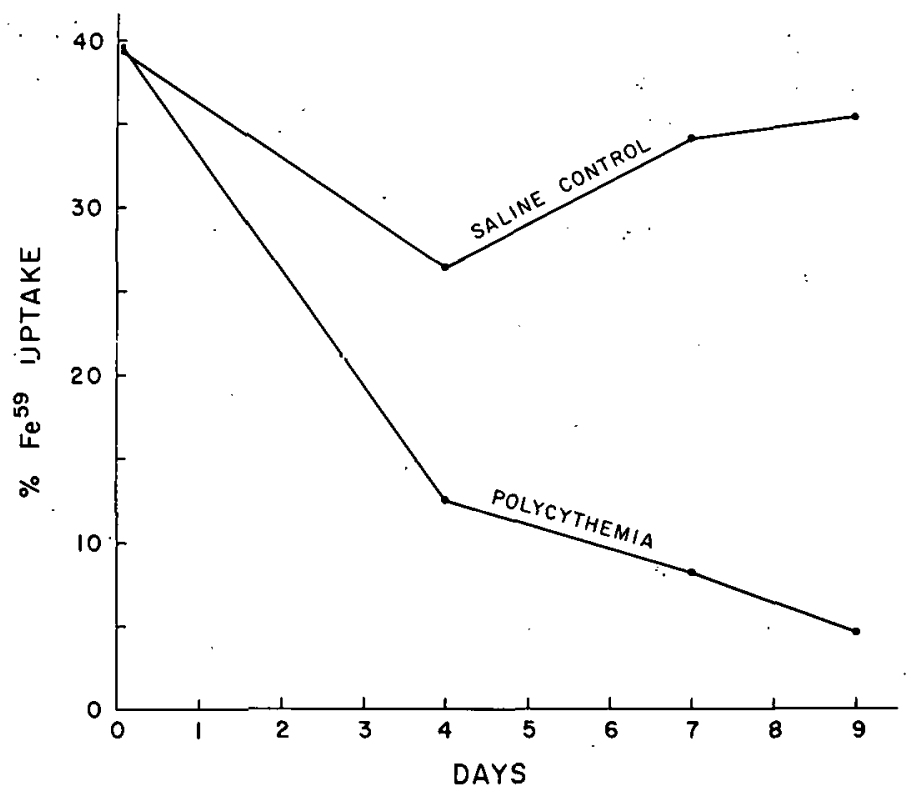

Figure 2. The effect of experimentally-induced polycythemia on the incorporation of $\mathrm{Fe}^{59}$ into the newly-formed red blood cells in the rat.

tion of $\mathrm{Fe}^{59}$. Rats weighing 150 to $200 \mathrm{~g}$ were given intraperitoneal injections as indicated in Table 1. $\mathrm{Fe}^{59}$ was administered 8 days later, and the following morning incorporation of iron and number of reticulocytes was obtained. Only a modest rise in hemoglobin was obtained following administration of smallest amount of blood, but a definite reduction in number of reticulocytes and incorporation of $\mathrm{Fe}^{59}$ was obtained (Table 1). It appears that packed cells in $4 \%$ of animal's body weight, elevating the hemoglobin to only $16.7 \mathrm{~g} \%$, are almost as efficacious in suppressing reticulocyte production and red cell $\mathrm{Fe}^{59}$ incorporation as twice this volume of packed cells, an amount producing a far more dramatic elevation of hemoglobin.

Table 1

DEPRESSION OF ERYTHROPOIESIS FOLLOWING EXPERIMENTAL POLYCYTHEMIA

\begin{tabular}{l|c|c|c|c|c|c}
\hline Vol. injected* & $\begin{array}{c}\text { Packed cells } \\
2 \%\end{array}$ & $\begin{array}{c}\text { Saline } \\
2 \%\end{array}$ & $\begin{array}{c}\text { Packed cells } \\
\mathbf{4} \%\end{array}$ & $\begin{array}{c}\text { Saline } \\
4 \%\end{array}$ & $\begin{array}{c}\text { Packed cells } \\
8 \%\end{array}$ & $\begin{array}{c}\text { Saline } \\
8 \%\end{array}$ \\
\cline { 2 - 6 } No. of animals & 5 & 5 & 5 & 4 & 5 & 4 \\
Hemoglobin & 15.6 & 14.6 & 16.7 & 13.6 & 2.1 .2 & 14.8 \\
Reticulocytes (\%) & 1.1 & 5.6 & .2 & 6.3 & .1 & 5.1 \\
$\mathrm{Fe}^{59}$ uptake (\%) & 19 & 48 & 8 & 48 & 6 & 48 \\
\hline
\end{tabular}
in $g$. 
Effect of rat plasma and heat-denatured extract of human plasma on incor poration of $\mathrm{Fe}^{59}$ into erythrocytes of the polycythemic rat. Rats weighing 75 to $125 \mathrm{~g}$ were given. packed red cells, in milliliters equal to $4 \%$ of body weight in $\mathrm{g}$. On 11 th and 12 th days after infusion, these animals received $2 \mathrm{ml}$ of plasma or plasma extract given subcutaneously (Figure 3). Radioiron uptake by the erythrocytes was then determined, the tracer dose being administered on the 13 th day after establishment of polycythemia. Approximately 6fold increases in $\mathrm{Fe}^{59}$ incorporation resulted from administration of anemic rat plasma or the heat-denatured extract of human plasma from an anemic patient.

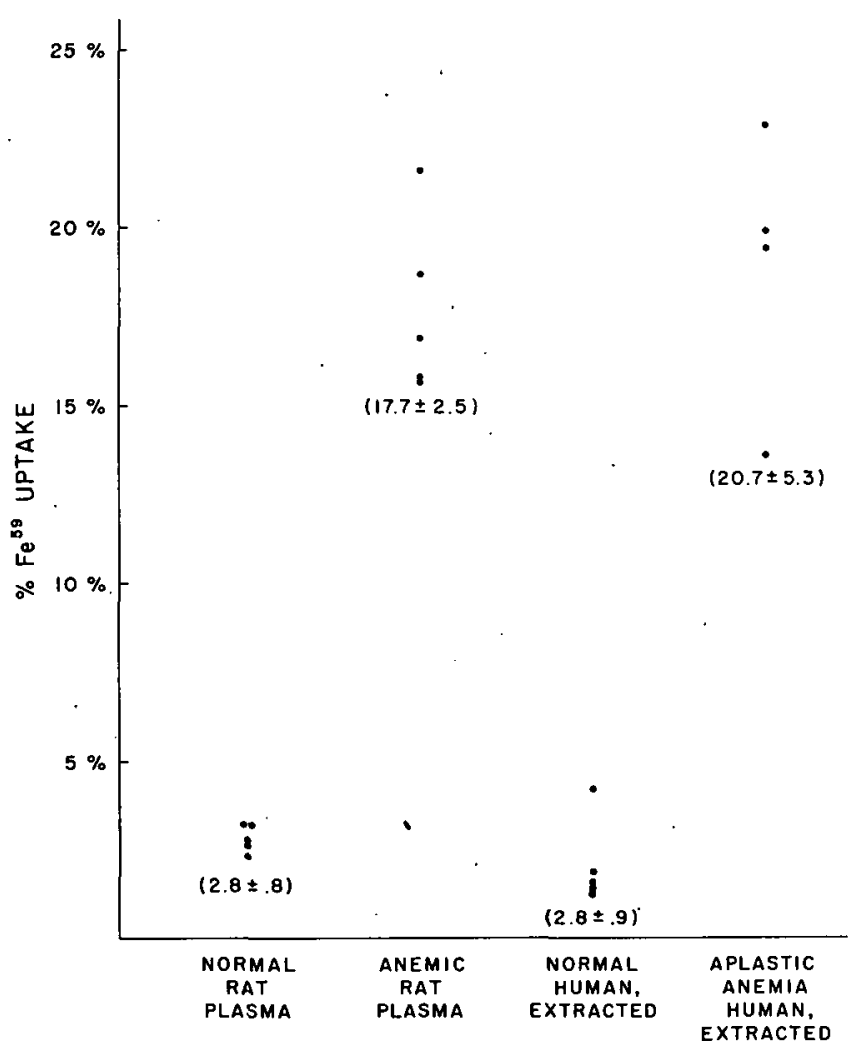

Figure 3. The effect of normal and anemic rat plasma and normal and anemic human plasma (heat-denatured extract) on the incorporation of $\mathrm{Fe}^{59}$ into newly-formed red blood cells in polycythemic rats. The numbers enclosed in parentheses are average values plus or minus one standard deviation.

Effect of cobalt on number of reticulocytes and uptake of $\mathrm{Fe}^{59}$ in polycythemic rat. Rats weighing 140 to $170 \mathrm{~g}$ were made polycythemic by intraperitoneal injection of packed cells in the volume in $\mathrm{ml}$ equal to $4 \%$ of their body weight in $\mathrm{g}$. On the third day after injection, the animals were divided into 2 groups by random selection. One group received 
cobaltous chloride subcutaneously and the other group received normal saline. On the 12 th day, $\mathrm{Fe}^{59}$ was administered and its incorporation was determined 16 hours later. Reticulocyte and hemoglobin values are recorded in Table 2. Although the animals were

Table 2

RETICULOCYTE RESPONSE FOLLOWING Co++ IN THE POLYCYTHEMIC RAT

\begin{tabular}{c|c|c|c|c|c|c}
\hline & \multicolumn{3}{|c|}{ CONTROL (5 rats) } & \multicolumn{3}{c}{ COBALT (4 rats) } \\
\hline Day & $\mathrm{Hb}$ & Retic. & Injection & $\mathrm{Hb}$ & Retic. & Injection \\
\hline 3 & & & Saline 1 cc/day & &, & Cobalt $5 \mu \mathrm{M} /$ day \\
6 & 17.8 & .3 & & 18.9 & .7 & \\
8 & 17.9 & .3 & & 18.5 & 1.6 & \\
10 & 17.1 & .1 & Saline 1 cc B.I.D. & 18.0 & 1.7 & Cobalt 5 $\mu$ M B.I.D. \\
12 & 17.2 & .3 & & 18.2 & 2.5 & \\
\hline
\end{tabular}

fortuitously divided in such a manner that the saline control group on all occasions had slightly lower average hemoglobin values than the animals receiving the cobalt, reticulocyte averages were higher in the animals receiving the cobalt. This difference became more striking as time passed. Further, the incorporation of $\mathrm{Fe}^{59}$ into newly-formed red cells in polycythemic animals was increased from an average value of $5 \%$ in the rats receiving saline to an average value of $32 \%$ in the rats receiving cobalt.

Effect of multiple transfusions on reticulocyte count in the polycythemic rat. Four rats weighing 150 to $185 \mathrm{~g}$ were made and maintained polycythemic for 48 days by multiple transfusions in an effort to obtain complete suppression of erythropoiesis as indicated by a complete disappearance of reticulocytes in the peripheral blood. At least 4 days elapsed after each transfusion before counts were repeated in order to permit maturation of transfused reticulocytes. A 50\% suspension of red cells in saline was used after the first week in an effort to eliminate stimulation of erythropoiesis by erythropoietin present in normal plasma. Once polycythemia was established, every reticulocyte value in Table 3 was determined by examining 10,000 red cells. It was not possible to rid the rats completely of reticulocytes, although while the hemoglobin was maintained above $20 \mathrm{~g}$, it frequently was necessary to count 10,000 red cells on a smear to find a single reticulocyte (Table 3 ).

Effect of polycythemia on reticulocyte count of hypophysectomized rat. Six days after hypophysectomy, the reticulocyte count of 9 -week-old $120-140 \mathrm{~g}$ rats averaged $.06 \%$ and average hemoglobin was $18.9 \mathrm{~g} \%$. None of 7 rats was completely free of reticulocytes, however. Two daily intravenous injections of blood, totaling $14 \mathrm{ml}$ per rat, were given and 8 days later the average hemoglobin was $23.4 \mathrm{~g} \%$. The average reticulocyte count was $.006 \%$, and in 4 of the 7 rats, the count was $0.00 \%$, no reticulocytes being seen in 10,000 cells. 
Table 3

RETICULOCYTE SUPPRESSION IN PROLONGED TRANSFUSIONINDUCED POLYCYTHEMIA

\begin{tabular}{r|c|c|c|c|c|c|c|c}
\hline \multirow{2}{*}{ Day } & \multicolumn{2}{|c|}{1} & \multicolumn{2}{c|}{2} & \multicolumn{2}{c|}{3} & \multicolumn{2}{c}{4} \\
\cline { 2 - 9 } & $\mathrm{Hb}$ & $\begin{array}{c}\text { Retic. } \\
\%\end{array}$ & $\mathrm{Hb}$ & $\begin{array}{c}\text { Retic. } \\
\%\end{array}$ & $\mathrm{Hb}$ & $\begin{array}{c}\text { Retic. } \\
\%\end{array}$ & $\mathrm{Hb}$ & $\begin{array}{c}\text { Retic. } \\
\%\end{array}$ \\
\hline 0 & 11.6 & 5.7 & 9.6 & 6.4 & 10.4 & 5.2 & 12.3 & 6.9 \\
15 & 21.6 & - & 21.6 & .03 & 20.9 & .12 & 21.4 & .08 \\
25 & 22.7 & .03 & 24.0 & .02 & 22.8 & .03 & 23.4 & .10 \\
29 & 21.4 & .02 & 24.8 & .01 & 22.7 & .02 & 20.8 & .01 \\
48 & 21.2 & .02 & 19.4 & .04 & 19.4 & .04 & 21.4 & .03 \\
\hline
\end{tabular}

Transfusions given on days $0,4,7,11,18,19,20,29,40,41$.

\section{DISCUSSION}

The present investigation has been directed toward the accumulation of evidence that decreased erythrocyte formation in transfusion-induced polycythemia is a result of lowered erythropoietin titers. In this regard, it is of interest to note that the high titer of erythropoietin associated with some anemias in human beings declines when, as a consequence of transfusions, the hemoglobin increases. 21,22

Slight increases in circulating levels of hemoglobin reduce but do not completely inhibit erythrocyte production since reticulocyte production and iron uptake were reduced but not completely inhibited 8 days after transfusion. This reduction was greater when associated with increased plethora, but it is of interest to note that the reduction in erythropoiesis, as measured by the number of reticulocytes, appeared to be of about the same magnitude when the hemoglobin was $16.7 \mathrm{~g} \%$ as it was when the value was $21.2 \mathrm{~g} \%$. Since none of the animals in the latter group were free of reticulocytes, we then attempted to eliminate the reticulocyte count in the rat with multiple transfusions, as has been accomplished in mice. ${ }^{16}$ This reticulocyte count was easily depressed to $0.00 \%$ in several hypophysectomized rats made polycythemic. Although marked depression of the reticulocyte count was accomplished in the normal rat made polycythemic by transfusion, in no instance was a complete absence of reticulocytes found. It appears likely to us that the polycythemic rats do not deliver enough oxygen to the site of production of erythropoietin to completely suppress its formation, but after hypophysectomy the metabolic rates and oxygen requirements are depressed, and hence in the polycythemic hypophysectomized rat the additional oxygen made available after transfusion is sufficient to accomplish this purpose.

The increased uptake of $\mathrm{Fe}^{59}$ in the polycythemic rats following 2 injections of anemic, but not normal rat plasma, suggests that reduction of erythropoiesis in the plethoric rat is mediated through reduction of erythropoietin titers. This concept is fortified by the finding that the extract of plasma obtained from an anemic patient following removal of the 
bulk of the protein by heat-denaturation also increases the incorporation of iron in plethoric rats, while a similarly prepared extract of normal human plasma fails to do so. Further evidence for this concept is found in the cobalt-induced reversal of the depression of erythropoiesis in the polycythemic rat, since it has been demonstrated by Goldwasser and his co-workers ${ }^{23}$ that cobalt-induced polycythemia appears to be a consequence of increased erythropoietin production.

\section{SUMMARY}

1) Reduction of erythropoiesis in rats rendered polycythemic by intraperitoneal infusion of packed red cells bears a relation to the degree of plethora produced. Plasma from anemic rats, a heat-denatured plasma extract from a patient with aplastic anemia, and subcutaneous cobaltous chloride all stimulate erythropoiesis in the polycythemic rat. These observations are consistent with the theory that decreased erythropoiesis in the polycythemic rat is the immediate consequence of a decreased titer of erythropoietin in these animals, and constitute further support for the theory of the humoral regulation of erythropoiesis. 2) In these experiments it was not possible to suppress erythropoiesis completely, as measured by the reticulocyte count, in normal rat by transfusion, although complete suppression was readily accomplished in transfused hypophysectomized rat.

\section{LITERATURE CITED}

1. Carnot, P., and C. Deflandre. Compt. rend. Acad. sc., 143:384, 1906.

2. Reissmann, K. R. Blood, 5:372, 1950.

3. Stohlman, F., and G. Brecher. J. Lab. Clin. Med., 49:890, 1957.

4. Erslev, A. J. Ibid., 50:543, 1957.

5. Bl_ Blood, 8:349, 1953.

6. __ Proc. Soc. Exp. Biol. Med., 83:548, 1953.

7. Hodgson, G., and J. Toha. Blood, 9:299, 1954.

8. Gordon, A. S., S. J. Piliero, W. Kleinberg, and H. H. Freedman. Proc. Soc. Exp. Biol. Med., 86:255, 1954 .

9. Linman, J. W., and F. H. Bethell. Blood, 11:310, 1056.

10. Fried, W., L. F. Plzak, L. O. Jacobson, and E. Goldwasser. Proc. Soc. Exp. Biol. Med., 94:237, 1957.

11. Hass, R. Deutsch Arch. klin. Med., 95:482, 1909.

12. Robertson, O. H. J. Exp. Med., 26:221, 1917.

13. Krumbhaar, E. B., and A. Chanutin. Ibid., 35:847, 1922.

14. Elmlinger, P. J., R. L. Huff, and J. M. Oda. Proc. Soc. Exp. Biol. Med., 79:16, 1952.

15. Birkhill, F. R., M. A. Maloney, and S. M. Levenson. Blood, 6:1021, 1951. 
16. Jacobson, L. O., E. Goldwasser, L. F. Plzak, and W. Fried. Proc: Soc. Exp. Biol. Med., 94:243, 1957.

17. Evelyn, K. A. J. Biol. Chem., 115:63, 1936.

18. Plzak, L. F., W. Fried, L. O. Jacobson, and W. F. Bethard. J. Lab. Clin. Med., 46:671, 1955.

19. Berlin, N. I., R. L. Huff, D. C. Van Dyke, and T. G. Hennessey. Ibid., 71:176, 1949.

20. Bor sook, H., A. Graybiel, G. Keighley, and E. Windsor. Blood, 9:734, 1954.

21. Gurney, C. W., E. Goldwasser, and C. Pan. J. Lab. Clin. Med., 50:534, 1957.

22. Medici, P. T., A. S. Gordon, S. J. Piliero, A. L. Luhby; and P. Yuceoglu. Acta Hemat., $18: 325,1957$.

23. Goldwasser, E., L. O. Jacobson, W. Fried, and I. Plzak. Science, 125:1085, 1957. 


\section{STUDIES ON ERYTHROPOIESIS. X. THE USE OF BONE MARROW TISSUE CULTURE IN DEMONSTRATING ERYTHROPOIETIN *}

\section{By}

W. F. Rosse and C. W. Gurney

In recent years, the kinetics and controlling mechanisms of erythrocyte production have been studied extensively. One of the most important and interesting results of these investigations is the demonstration that a humoral substance(s) (erythropoietin) is responsible, at least, in part, for the increased erythropoiesis in response to hemorrhage, ${ }^{1-4}$ hemolytic anemia, ${ }^{5-6}$ hypoxia, ${ }^{7-8}$ and cobalt administration. ${ }^{9}$ Furthermore, indirect evidence has been accumulated showing that the amount of this factor $(\mathrm{s})$ is decreased when the production of erythrocytes is reduced as in transfusion-induced polycythemia ${ }^{10}$ and hyperoxia. ${ }^{11}$

To date, nearly all assays of erythropoietic activity have been carried out in whole animals. Increases in reticulocyte, hemoglobin, and hematocrit values ${ }^{2-7}$ as well as the increase in radioiron uptake ${ }^{1,8}$ have been used as parameters in assessing the effect of erythropoietin-rich serum on normal, starved, hypophysectomized, or polycythemic animals. Qualitative estimates of erythropoietic activity in the spleen and bone marrow have also been used as evidence of the presence or absence of erythropoietin. ${ }^{10}$ However, only one report ${ }^{12}$ of the quantitative estimation of the effect of serum rich in erythropoietin on proliferation of erythrocyte precursors was found in the literature.

The improvement in tissue culture techniques has made it possible to maintain tissue cells in vitro. It is the purpose of this paper to present some experiments wherein the effect of different sera upon bone marrow cells grown in tissue culture is measured quantitatively.

\section{METHODS AND PROCEDURES}

The chambers used in these experiments for the cultivation of the marrow cells were a modified version of the Mackeness and Smith monocyte culture chamber ${ }^{+13}$ (Figures 1 and 2). This consists of a block of unplasticized Perspex, $4.9 \times 3.2 \times 0.22 \mathrm{~cm}$. In the center, circular holes of $23-\mathrm{mm}$ diameter are counterbored from each side to within $1.5 \mathrm{~mm}$ of each other, and a hole, $19 \mathrm{~mm}$ in diameter, is drilled completely through. Thus the central hole is surrounded by a recessed border on both sides. From the side, two small holes,

\footnotetext{
* Preprint of a paper that will appear in The Journal of Laboratory and Clinical Medicine.

†Obtained from H. G. East \& Co., Oxford, England, and constructed in the Engineering Division of Argonne Cancer Research Hospital.
} 
$0.7 \mathrm{~mm}$ in diameter, are drilled into the central hole. The plug consists of two parallel wires of slightly smaller diameter set in a small piece of plastic at the same distance apart as the two lateral holes. A Perspex ring, $1 \mathrm{~mm}$ high and $6 \mathrm{~mm}$ inside and $8 \mathrm{~mm}$ outside diameters, from which a small arc has been removed completes the apparatus.

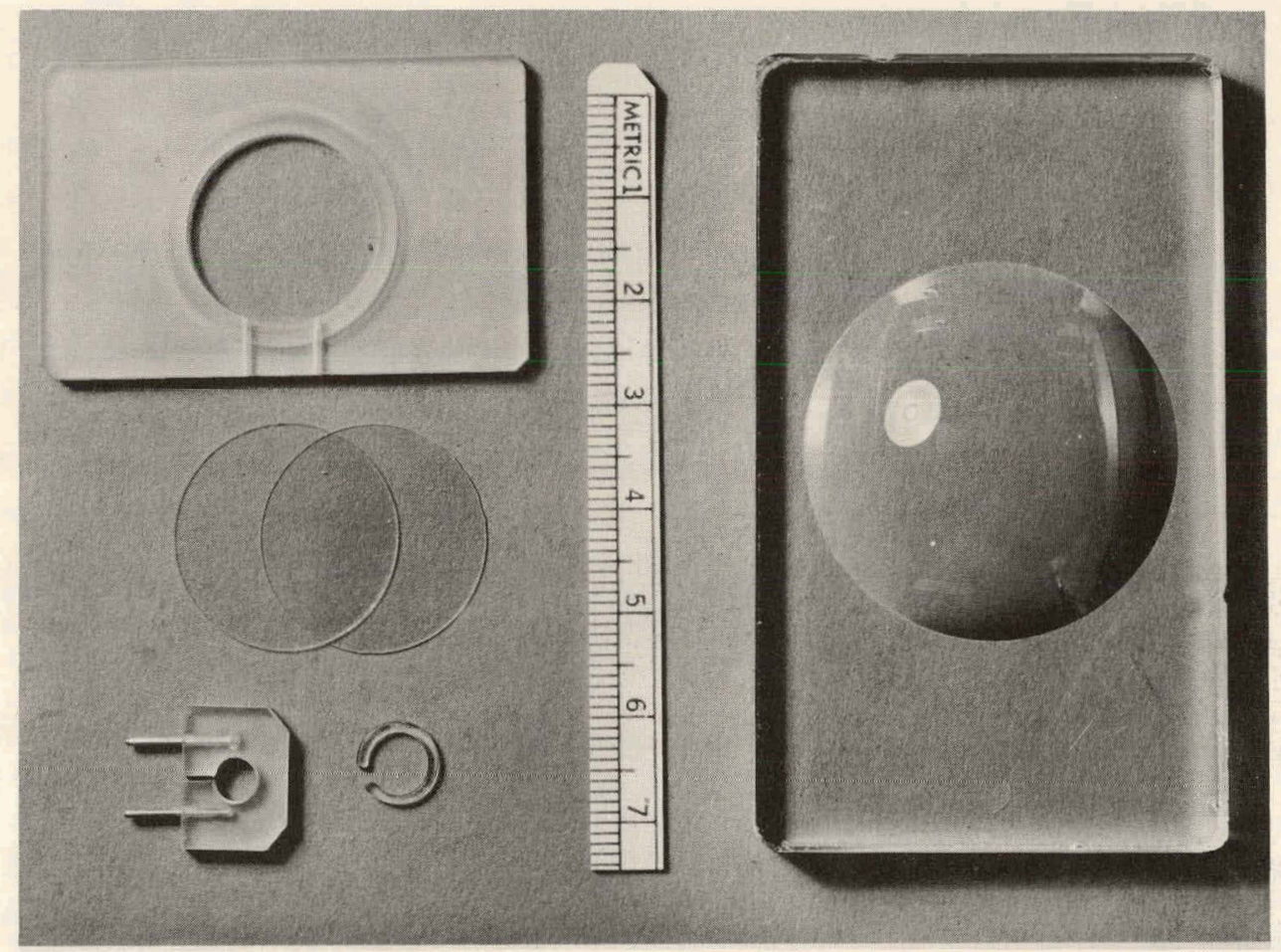

Figure 1. Component parts of the modified Mackeness and Smith monocyte culture chamber before assembly: upper left, main block; middle left, cover glasses; lower left, plug and internal rings; right, inverted shallow well glass slide used to support main block during sterilization.

The plastic chamber is constructed after sterilization in dry heat at $\left(100-105^{\circ} \mathrm{C}\right)$, for $1 \mathrm{hr}$. , using paraffin (melting point $56-58^{\circ} \mathrm{C}$ ). A chemically clean and sterile circular cover slip, $22 \mathrm{~mm}$ in diameter, is placed on one recessed border and secured with melted wax. The chamber is inverted after cooling, and the previously waxed central ring is placed so that a needle may be inserted through a lateral hole and into the center of the ring through the missing arc. A cover glass is placed on the top recessed edge and the bottom cover glass is gently heated to melt the wax on the central ring, thus securing it. The top glass is then secured with melted wax.

The culture medium used was Earle's salt solution ${ }^{*}$ with added vitamins, ${ }^{*}$ amino acids, ${ }^{*}$ and glutamine ${ }^{*}$ in amounts twice Eagle's specifications. ${ }^{14-16}$ The serum used was

\footnotetext{
* Obtained from Microbiological Supplies, Bethesda, Maryland.
} 
taken under sterile conditions by cardiac puncture from Holtzman strain rats that had been fasted overnight. The following sera were tested: (1) Serum from normal 200- to 300g rats (normal serum); (2) serum from rats that had been made anemic by hemorrhage on two consecutive previous days and in which the hematocrit was less than $25 \%$ (anemic

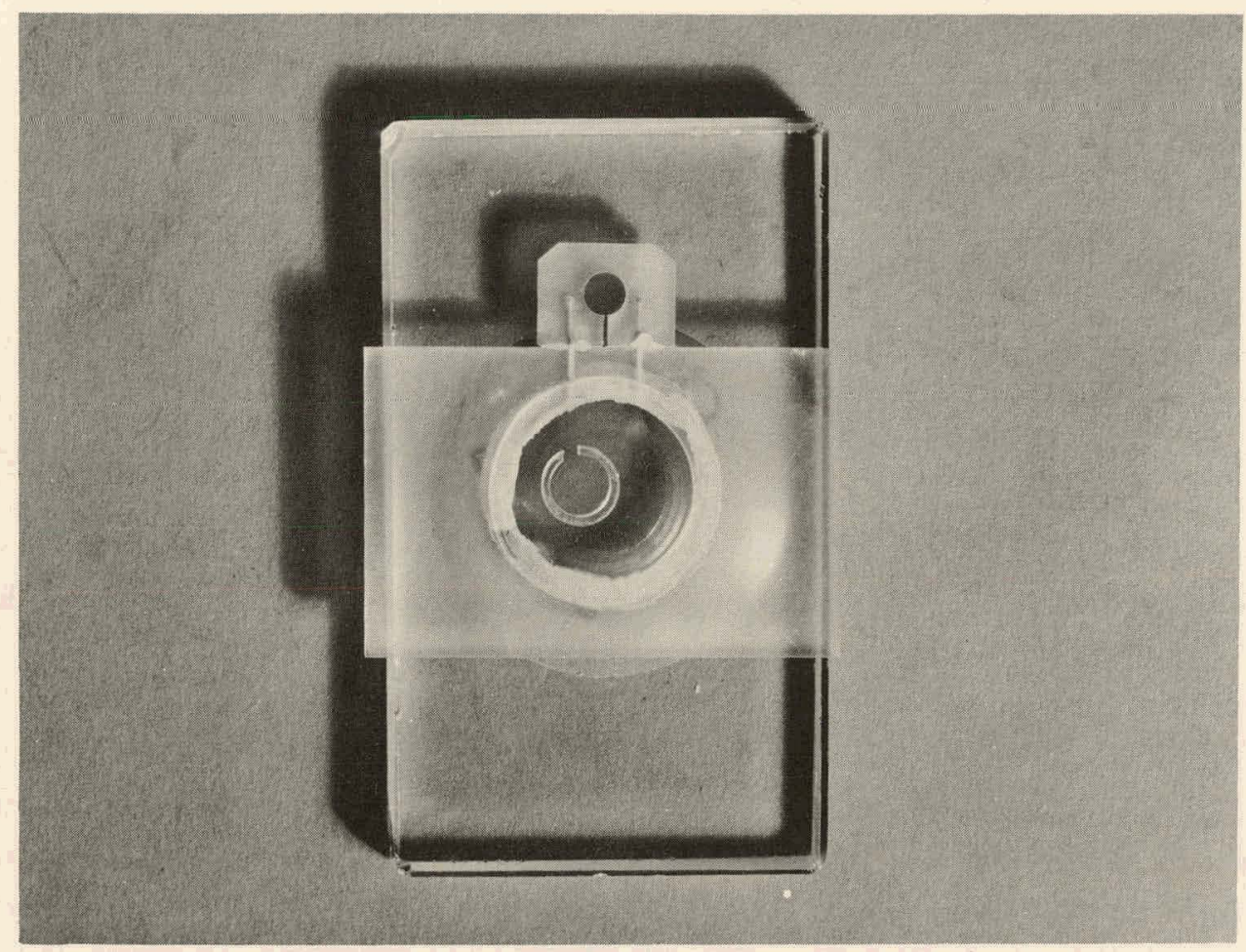

Figure 2. Modified Mackeness and Smith monocyte culture chamber fully assembled.

serum); (3) serum from rats given cobaltous chloride $(25 \mu \mathrm{M} / 100 \mathrm{~g}$ body wt.) with tracer amounts of radioactive cobalt-60 $10 \mathrm{hrs}$. previously (cobalt serum); (4) normal rat serum with an amount of cobaltous chloride added in vitro equal to the amount present in the cobalt serum (cobalt control serum); and (5) serum from rats that had been rendered polycythemic by transfusion of erythrocytes equal to $4 \%$ of the body weight given over a period of 3 days and in which the hematocrit was 65-70\% (polycythemic serum).

The marrow cells were obtained by means of sterile dissection of both femurs of a rat killed by cervical fracture, and were placed in $5 \mathrm{cc}$ of Earle's salt solution to which had been added sodium versenate (Disodium ethylenediamine tetracetate) in concentration of $1.5 \mathrm{mg} / \mathrm{ml}$. The cells were agitated, and the multicellular clumps allowed to settle to the bottom by tilting the tube at an angle of $45^{\circ}$ in ice water for 5-10 minutes. The supernatant suspension of single cells and smaller clumps of cells was removed and centrifuged for 10 minutes at $1200 \mathrm{rpm}$, and the acellular supernatant was removed. The cells were resuspended in enough Eagle's medium (without serum) to make a concentration of 6000- 
8000 nucleated cells per cu mm. Two parts of this cellular suspension were added to 1 part of each of the sera being tested. Likewise, two parts of Eagle's medium were added to 1 part of each of the sera, making the medium complete.

Six-hundredths $\mathrm{ml}$ of the cellular suspension was placed inside the ring of each chamber with a tuberculin syringe equipped with a \#22 needle. The space between the ring and the main part of the chamber was partially filled with the corresponding complete medium, leaving an air bubble. The plug was dipped in a 1:1 mixture of paraffin and yellow petrolatum, and the wires were inserted into the two lateral holes. The chambers were incubated at $37^{\circ} \mathrm{C}$, and were rotated at 6 - to $12-\mathrm{hr}$. intervals. Ten to fifteen replicate cultures were prepared for each serum tested.

At specified time intervals, the upper coverglass was removed and the ring loosened. The medium was agitated gently to remove all cells from the bottom and carefully aspirated and measured with a tuberculin syringe graduated in $0.01-\mathrm{ml}$ units. The chamber was washed twice with $0.2 \mathrm{ml} 2 \%$ acetic acid, and the recovered wash fluid measured carefully. No cells remained on the bottom cover glass. The number of nucleated cells per cu $\mathrm{mm}$ was counted without further dilution on a regular Neubauer hemocytometer; two separate aliquots were used. The total number of cells removed was calculated. This process was performed on three chambers of a particular serum at each time.

Slides for differential count were made on two chambers of each serum at each time. The top cover glass was removed, and the supernatant fluid removed carefully while the central ring was still attached. The cells remaining on the bottom cover glass were quickly air-dried and stained with Wright's stain after removing the cover glass from the chamber and the ring from the cover glass. The cover glasses were mounted cells downward on regular glass slides and labeled so that they could be counted as unknowns. Differential count of 1000 cells on each slide was performed in a systematic fashion, counting the cells in separate microscope fields along the horizontal, vertial, and (occasionally) diagonal diameters of the cellular area.

From these data, the total number of any particular cell type or types can be calculated.

$$
\begin{aligned}
& \text { Number of } \\
& \text { type A cells }
\end{aligned}=\left(\text { total cells } / \mathrm{mm}^{3} \times \mathrm{mm}^{3}\right) \times \frac{\% \text { of type A cells }}{100}
$$

\section{RESULTS}

The number of erythrocytic precursors was plotted against time of incubation (see Figures 3, 4, and 5). In the presence of normal serum, the number of these cells decreased linearly throughout the 24-hour period. In cultures incubated with anemic serum, the number of these cells increased during the first 12 hours and decreased during the second 12hour period. Cobalt serum elicited the same response and cultures incubated in cobalt control serum behaved similarly to those in normal serum. With polycythemic serum, the number of erythrocyte precursors at $12 \mathrm{hrs}$. was significant by below the number in cultures 


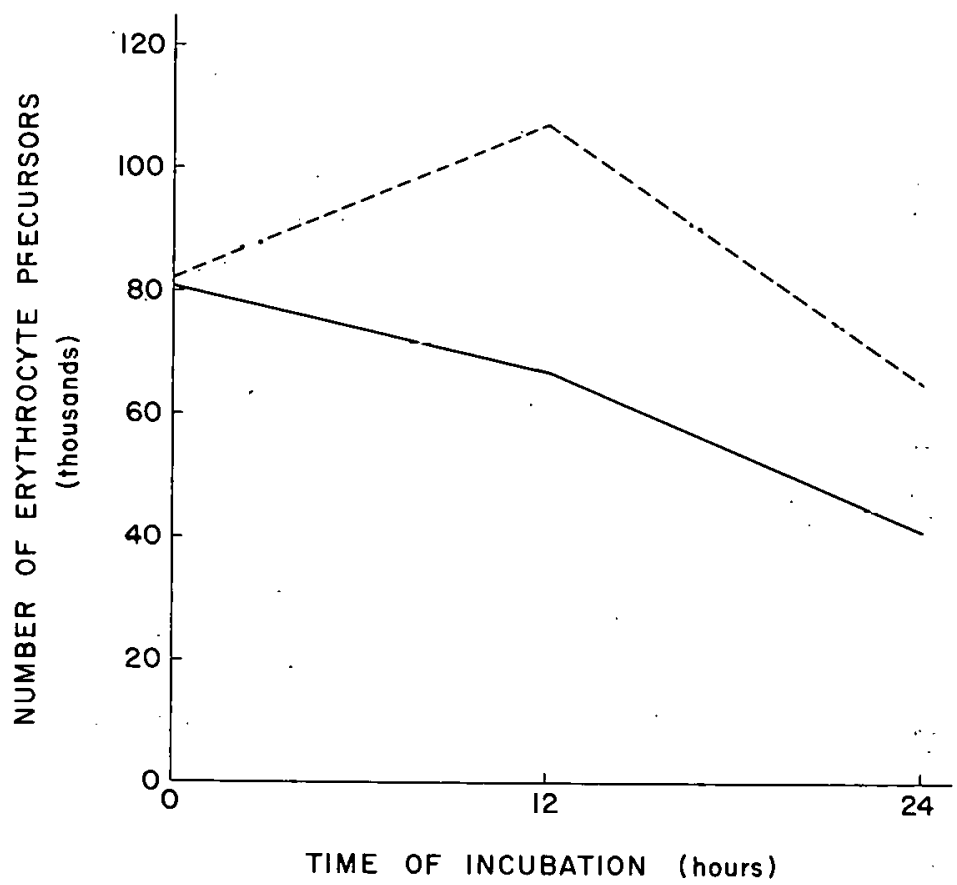

Figure 3. Total number of erythrocyte precursors in bone marrow tissue cultures grown in normal and anemic serum,

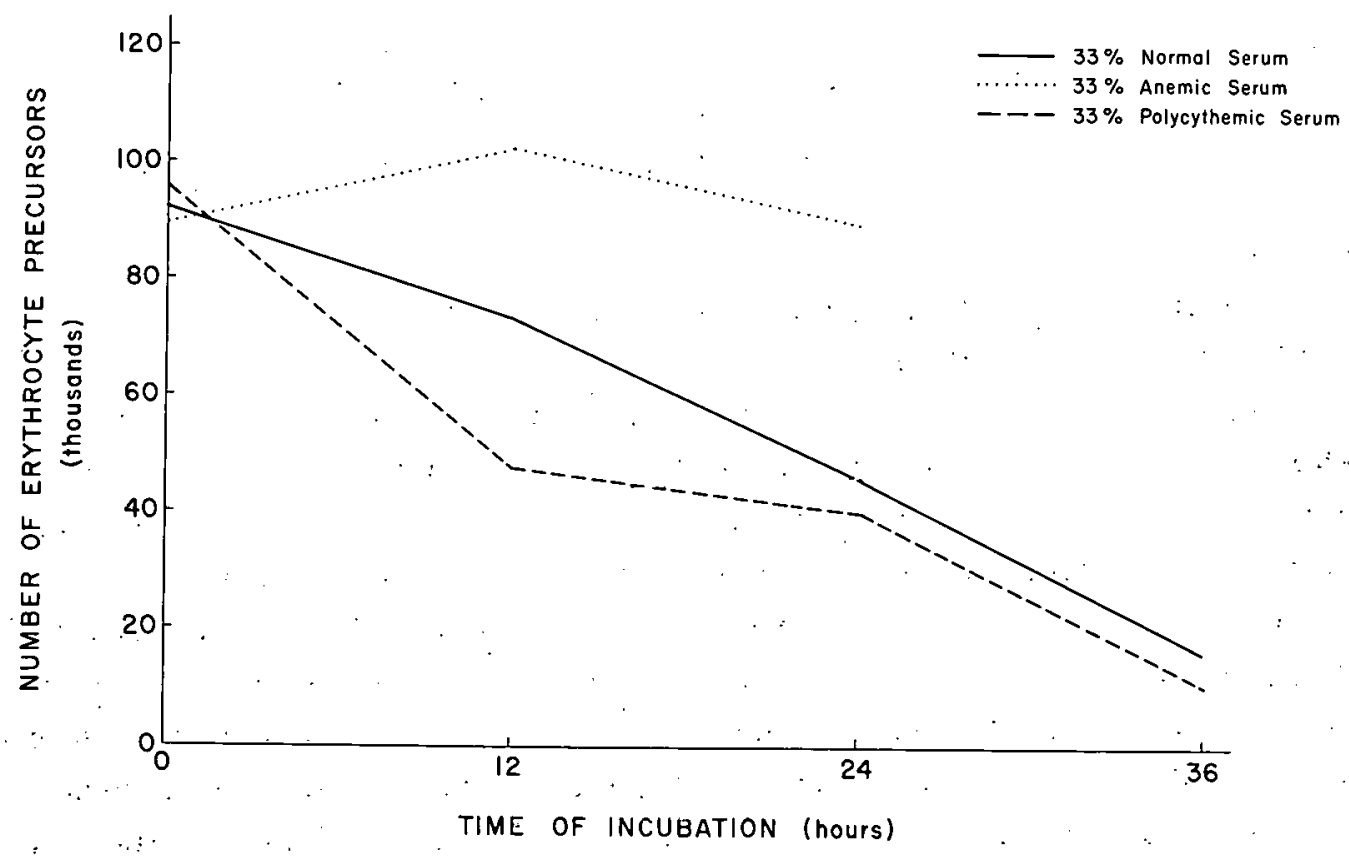

Figure 4. Total number of erythrocyte precursors in bone marrow tissue cultures grown in normal, anemic, and polycythemic serum. 


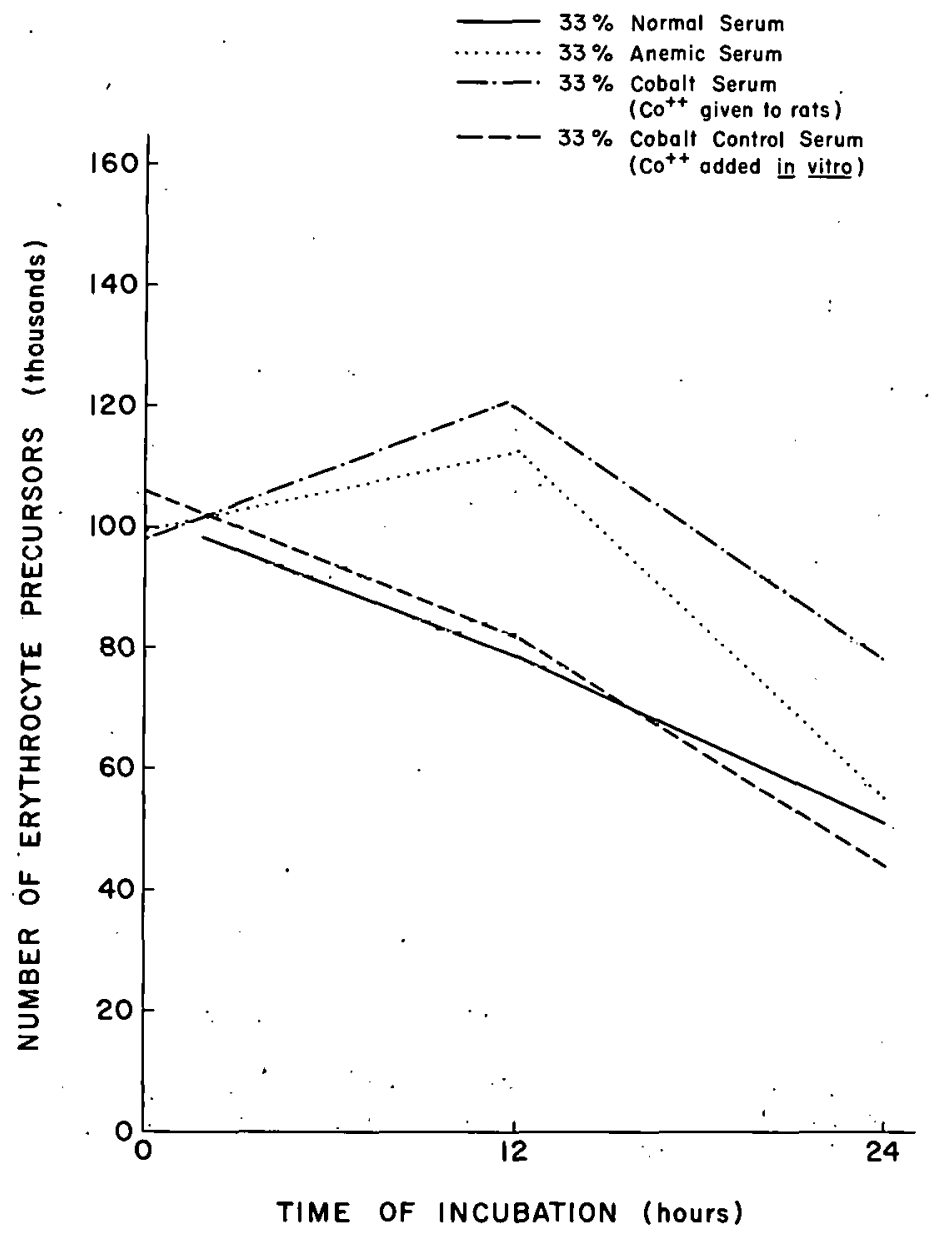

Figure 5.' Total number of erythrocyte precursors in bone marrow tissue cultures grown in normal, anemic, cobalt, and cobalt control serum.

using normal serum. During the following $24 \mathrm{hrs}$. (12-36 hrs. incubation) the number of erythrocyte precursors in the polycythemic cultures was lower than in the normal cultures but the difference was not so striking.

The number of each of the erythrocyte precursors (rubriblast, prorubricyte, rubricyte, and metarubricyte) was analyzed for each of the time intervals (Tables 1, 2, and 3). In three out of the four experiments (anemic or cobalt serum), it was observed that at $12 \mathrm{hrs.}$, the number of metarubricytes was increased above the original number at 0 hour: this increase was maintained through 24 hours. In one experiment with anemic serum (Experiment 3 ), the number of metarubricytes was only slightly higher at $12 \mathrm{hrs}$. and had decreased by $24 \mathrm{hrs}$. At this same interval the number of rubricytes and prorubricytes was increased over the original number and was considerably higher than the number of these cells in normal cultures. During the second $12 \mathrm{hr}$. period, the number of these cells decreased at a rate greater than that seen in normal cultures. Rubriblasts are so scarce in the cultures that changes in their number cannot be accurately assessed. 
Table 1 Experiment 1

NUMBERS AND PERCENTAGES (OF TOTAL NUCLEATED CELLS) OF ERYTHROCYTE PRECURSORS IN BONE MARROW CULTURED WITH NORMAL AND ANEMIC SERA

\begin{tabular}{|c|c|c|c|c|c|}
\hline \multirow{3}{*}{$\frac{\text { Hour }}{\text { Serum }}$} & \multicolumn{5}{|c|}{ INTERVAL OF INCUBATION (HRS.) } \\
\hline & \multirow[t]{2}{*}{0} & \multicolumn{2}{|c|}{12} & \multicolumn{2}{|c|}{24} \\
\hline & & Normal & Anemic & Normal & Anemic \\
\hline Total cell count & 301,240 & 267,430 & 271,170 & 199,630 & 245,480 \\
\hline $\begin{array}{l}\text { Metarubricyte } \\
\text { (No.) }\end{array}$ & 26,810 & 44,130 & 45,010 & 30,540 & 43,690 \\
\hline$(\%)$ & 8.9 & 16.5 & 16.6 & 15.3 & 17.8 \\
\hline $\begin{array}{l}\text { Rubricyte } \\
\text { (No.) }\end{array}$ & 28,610 & 17,380 & 37,690 & 8,980 & 15,710 \\
\hline$(\%)$ & 9.5 & 6.5 & . 13.9 & 4.5 & 6.4 \\
\hline $\begin{array}{l}\text { Prorubricyte } \\
\text { (No.) }\end{array}$ & 24,010 & 5,350 & 21,960 & 1,200 & 5,150 \\
\hline$(\%)$ & 8.0 & 2.0 & 8.1 & 0.6 & 2.1 \\
\hline $\begin{array}{l}\text { Rubriblast } \\
\text { (No.) }\end{array}$ & 2,410 & 2,670 & 2,980 & 200 & 490 \\
\hline$(\%)$ & 0.8 & 0.1 & 1.1 & 0.1 & 0.2 \\
\hline $\begin{array}{l}\text { Total erythrucyte } \\
\text { precursors } \\
\text { (No.) }\end{array}$ & 79,430 & 69,530 & 107,640 & 40,920 & 65,040 \\
\hline$(\%)$ & 27.2 & 25.1 & 39.7 & 20.5 & 26.5 \\
\hline
\end{tabular}

When polycythemic serum was used there was a decrease in the number of metarubricytes and rubricytes that was more rapid than that seen in normal cultures during the first $12 \mathrm{hrs}$.

\section{DISCUSSION}

Normal serum. The linear decrease of erythrocyte precursors in normal cultures is the product of interaction of several factors. The number of precursors present at any time represents the balance between proliferation, cell death, and maturation to anuclear erythrocytes during the preceding period of time. Cell death may be large in these cultures because the environmental conditions in the chamber are suboptimal as compared with marrow in situ. Proliferation is probably decreased and maturation increased by "progressive maturation of the culture," i.e., the tendency of all the cells in the culture to mature and thus become incapable of dividing and maintaining the line. Osgood ${ }^{17} \mathrm{em}-$ 
Table 2 Experiment 2

NUMBERS AND PERCENTAGES (OF TOTAL NUCLEATED CELLS) OF ERYTHROCYTE PRECURSORS IN BONE MARROW CULTURED IN NORMAL, ANEMIC, OR POLYCYTHEMIC SERUM

\begin{tabular}{|c|c|c|c|c|c|c|c|c|}
\hline \multirow[b]{3}{*}{ Serum } & \multicolumn{8}{|c|}{ INTERVAL OF INCUBATION (HRS.) } \\
\hline & \multicolumn{3}{|c|}{12} & \multicolumn{3}{|c|}{24} & \multicolumn{2}{|l|}{36} \\
\hline & Normal & Anemic & $\begin{array}{l}\text { Polycy- } \\
\text { themic }\end{array}$ & Normal & Anemic & $\begin{array}{l}\text { Polycy- } \\
\text { themic }\end{array}$ & Normal & $\begin{array}{l}\text { Polycy- } \\
\text { themic }\end{array}$ \\
\hline Total cell count & 252,380 & 260,050 & 228,320 & 208,310 & 252,680 & 187,160 & 143,290 & 135,100 \\
\hline $\begin{array}{l}\text { Metarubricytes } \\
\text { (No.) } \\
\text { (\%) }\end{array}$ & $\begin{array}{r}40,380 \\
16.0\end{array}$ & $\begin{array}{r}64,490 \\
24.8\end{array}$ & $\begin{array}{c}31,050 \\
13.6\end{array}$ & $\begin{array}{r}31,250 \\
15.0\end{array}$ & $\begin{array}{r}65,410 \\
25.9\end{array}$ & $\begin{array}{r}26,760 \\
14.3\end{array}$ & $\begin{array}{r}10,750 \\
7.5\end{array}$ & $\begin{array}{r}6,620 \\
4.9\end{array}$ \\
\hline $\begin{array}{l}\text { Rubricytes } \\
(\text { No.) } \\
(\%)\end{array}$ & $\begin{array}{r}22,460 \\
8.9\end{array}$ & $\begin{array}{r}26,780 \\
10.3\end{array}$ & $\begin{array}{r}9,580 \\
4.2\end{array}$ & $\begin{array}{r}10,830 \\
5.2\end{array}$ & $\begin{array}{r}17,180 \\
6.8\end{array}$ & $\begin{array}{r}10,290 \\
5.5\end{array}$ & $\begin{array}{r}4,300 \\
3.0\end{array}$ & $\begin{array}{r}2,560 \\
1.9\end{array}$ \\
\hline $\begin{array}{l}\text { Prorubricytes } \\
\text { (No.) } \\
(\%)\end{array}$ & $\begin{array}{r}9,340 \\
3.7\end{array}$ & $\begin{array}{r}8,580 \\
3.3\end{array}$ & $\begin{array}{r}7,300 \\
3.2\end{array}$ & $\begin{array}{r}4,170 \\
2.0\end{array}$ & $\begin{array}{r}5,550 \\
2.2\end{array}$ & $\begin{array}{r}2,990 \\
1.6\end{array}$ & $\begin{array}{l}500 \\
0.4\end{array}$ & $\begin{array}{r}800 \\
0.6\end{array}$ \\
\hline $\begin{array}{l}\text { Rubriblasts } \\
\text { (No.) } \\
\cdot(\%)\end{array}$ & $\begin{array}{r}500 \\
0.2\end{array}$ & $\begin{array}{r}2,080 \\
0.8\end{array}$ & $\begin{array}{r}200 \\
0.1\end{array}$ & $\begin{array}{r}0 \\
0.0\end{array}$ & $\begin{array}{l}700 \\
0.3\end{array}$ & $\begin{array}{r}200 \\
0.1\end{array}$ & $\begin{array}{r}200 \\
0.2\end{array}$ & $\begin{array}{l}100 \\
0.1\end{array}$ \\
\hline $\begin{array}{l}\text { Total erythrocyte } \\
\text { precursors } \\
\text { (No.) } \\
(\%)\end{array}$ & $\begin{array}{r}72,680 \\
28.8\end{array}$ & $\begin{array}{r}101,930 \\
39.2\end{array}$ & $\begin{array}{r}48,130 \\
21.1\end{array}$ & $\begin{array}{r}46,250 \\
22.2\end{array}$ & $\begin{array}{r}88,840 \\
35.2\end{array}$ & $\begin{array}{r}40,240 \\
21.5\end{array}$ & $\begin{array}{r}15,750 \\
11.1\end{array}$ & $\begin{array}{r}10,080 \\
7.5\end{array}$ \\
\hline
\end{tabular}


Table 3 Experiment 3

NUMBERS AND PERCENTAGES (OF TOTAL NUCLEATED CELLS) OF ERYTHROCYTE PRECURSORS IN BONE MARROW CULTURED IN NORMAL, ANEMIC, COBALT CONTROL, OR COBALT SERUM

\begin{tabular}{|c|c|c|c|c|c|c|c|c|c|}
\hline \multirow[b]{3}{*}{ Serum } & \multicolumn{9}{|c|}{ INTERVAL OF INCUBATION (HRS.) } \\
\hline & \multirow[t]{2}{*}{0} & \multicolumn{4}{|c|}{12} & \multicolumn{4}{|c|}{24} \\
\hline & & Normal & Anemic & $\begin{array}{l}\text { Cobalt } \\
\text { control } \\
\end{array}$ & Cobalt & Normal & Anemic & $\begin{array}{l}\text { Cobalt } \\
\text { control } \\
\end{array}$ & Cobalt \\
\hline Total cell count & 232,990 & 245,420 & 217,230 & 249,420 & 246,560 & 184,620 & 202,030 & 155,790 & 229,790 \\
\hline $\begin{array}{l}\text { Metarubricytes } \\
\text { (No.) } \\
\text { (\%) }\end{array}$ & $\begin{array}{r}58,010 \\
24.9\end{array}$ & $\begin{array}{r}49,080 \\
20.0\end{array}$ & $\begin{array}{r}59,030 \\
27.3\end{array}$ & $\begin{array}{r}55,120 \\
22.1\end{array}$ & $\begin{array}{r}67,800 \\
27.5\end{array}$ & $\begin{array}{r}38,400 \\
20.8\end{array}$ & $\begin{array}{r}33,130 \\
16.4\end{array}$ & $\begin{array}{r}35,050 \\
22.5\end{array}$ & $\begin{array}{r}69,170 \\
30.1\end{array}$ \\
\hline $\begin{array}{l}\text { Rubricytes } \\
(\text { No.) } \\
(\%)\end{array}$ & $\begin{array}{r}27,260 \\
11.7\end{array}$ & $\begin{array}{r}21,840 \\
8.9\end{array}$ & $\begin{array}{r}33,020 \\
15.2\end{array}$ & $\begin{array}{r}21,700 \\
8.7\end{array}$ & $\begin{array}{r}25,400 \\
10.3\end{array}$ & $\begin{array}{r}9,800 \\
5.3\end{array}$ & $\begin{array}{r}11,920 \\
5.9\end{array}$ & $\begin{array}{r}7,480 \\
4.8\end{array}$ & $\begin{array}{r}10,340 \\
4.5\end{array}$ \\
\hline $\begin{array}{l}\text { Prorubricytes } \\
\text { (No.) } \\
(\%)\end{array}$ & $\begin{array}{r}14, \leq 50 \\
6.2\end{array}$ & $\begin{array}{r}6,630 \\
2.7\end{array}$ & $\begin{array}{r}18,250 \\
8.4\end{array}$ & $\begin{array}{r}4,490 \\
\cdot 1.8\end{array}$ & $\begin{array}{r}21,700 \\
8.8\end{array}$ & $\begin{array}{r}2,400 \\
1.3\end{array}$ & $\begin{array}{r}8,280 \\
4.1\end{array}$ & $\begin{array}{r}470 \\
0.3\end{array}$ & $\begin{array}{r}4,360 \\
1.9\end{array}$ \\
\hline $\begin{array}{l}\text { Rubriblasts } \\
(\text { No.) } \\
(\%)\end{array}$ & $\begin{array}{r}1,630 \\
0.7\end{array}$ & $\begin{array}{r}1,000 \\
0.4\end{array}$ & $\begin{array}{r}2,390 \\
1.1\end{array}$ & $\begin{array}{r}200 \\
0.1\end{array}$ & $\begin{array}{r}6,160 \\
2.5\end{array}$ & $\begin{array}{l}500 \\
0.3\end{array}$ & $\begin{array}{r}1,000 \\
0.5\end{array}$ & $\begin{array}{r}0 \\
0.0\end{array}$ & $\begin{array}{r}0 \\
0.0\end{array}$ \\
\hline $\begin{array}{l}\text { Total erythrocyte } \\
\text { precursors. } \\
\text { (No.) } \\
(\%)\end{array}$ & $\begin{array}{r}101,350 \\
43.5\end{array}$ & $\begin{array}{r}78,550 \\
32.0\end{array}$ & $\begin{array}{r}112,690 \\
52.0\end{array}$ & $\begin{array}{r}81,510 \\
\quad \quad 32.7\end{array}$ & $\begin{array}{r}121,060 \\
49.1\end{array}$ & $\begin{array}{r}51,100 \\
27.7\end{array}$ & $\begin{array}{r}54,330 \\
26: 9\end{array}$ & $\begin{array}{r}43,000 \\
27.6\end{array}$ & $\begin{array}{r}83,870 \\
36.5\end{array}$ \\
\hline
\end{tabular}


phasized that when an immature cell divides, one of the daughter cells must remain immature and the other must mature if the normal numerical relationships are to be maintained. There is good evidence that this delicate balance is not maintained in these cultures since the proportion of metarubricytes and segmented neutorphils to total erythrocyte precursors and total granulocytes, respectively, increases and the proportion of more immature forms decreases with time. Thus all factors tend to decrease the number of erythrocyte precursors during any time interval.

Anemic serum. The increase in the total number of erythrocyte precursors during a 12-hr. incubation with anemic serum suggests that the erythropoietic-stimulating factor(s) (erythropoietin) is present in anemic serum in a form that is directly usable by the bone marrow cells. The proliferative stimulatory effect of this factor(s) is apparently upon the prorubricytes and rubricytes.

As in the normal cultures, the decline in erythrocyte precursors during the second $12 \mathrm{hrs}$. is the result of three processes: proliferation, cell death, and maturation. Again, progressive maturation of the culture is occurring: this tends to offset any stimulatory effect of the serum on proliferation by reducing the number of cells that are capable of division. It is impossible to state with certainty whether maturation of single crythrocyte precursors and/or progressive maturation of the culture is hastened by the stimulatory effect of the anemic serum. The more rapid decline in rubricytes and prorubricytes during this period suggests that both individual and progressive maturation are probably hastened by the active serum.

Cobalt and cobalt control sera. When cobalt serum was used, there was evidence of stimulation to the same degree as in anemic serum. When cobalt control serum was used, no such activity was demonstrated. These facts substantiate the findings of Goldwasser et al. ${ }^{2,18}$ that the erythropoietic effect of cobalt is mediated through a humoral mechanism (erythropoietin). In addition, the almost exact correspondence of erythrocyte precursors in the cultures grown in cobalt control serum with those grown in normal serum indicates that there is no direct effect of the ion on the bone marrow at these concentrations. These results are in agreement with the observations of Laforet and Thomas 19 who found no direct stimulatory effect of cobalt ion on bone marrow when oxygen levels and heme synthesis were analyzed in cultures.

Polycythemic serum. When animals are rendered polycythemic by transfusion, the amount of circulating erythropoietin is presumably reduced because the amount of oxygen at the site of production is increased and thus the stimulus for production is reduced. 11 Erythropoiesis in the transfusion-induced polycythemic mouse spleen is reduced. ${ }^{10}$ In the present experiments, the lower number of erythrocyte precursors in polycythemic cultures as compared with that in normal cultures at $12 \mathrm{hrs}$. is presumptive evidence that the amount of erythropoietin is greater in normal serum than in polycythemic serum and that erythropoietin is necessary to maintain a "normal" state of erythropoiesis. (However, the presence of an inhibitor of erythropoiesis in the polycythemic serum cannot be ruled out with absolute certainty.) Erythropoietin appears to be one of the controlling mechanisms in 
the normal state and not merely an emergency mechanism to stimulate erythropoiesis during stress.

\section{ERRORS OF MEASUREMENT}

The over-all effects of the various treatments are clear from examination of Figures 3 to 5 . Although three chambers were used to determine each total cell count, ordinarily only one or two differential counts were made for each treatment at each time. Thus we can measure directly the precision of a total cell count, but not that of differential count or of its product, the total erythrocyte precursor count. However, in some preliminary experiments replicate differential counts were made, and we have used these to measure the precision of differential counts.

It was found that the coefficient of variation (standard deviation divided by the mean count) of repeated total counts was approximately $12 \%$ (somewhat smaller for the zero hour counts) and consequently the coefficient of variation of the average of three such counts, being less by a factor of $1 / \sqrt{3}$, is approximately $7 \%$. For counts in the neighborhood of 200, the standard error is thus approximately 14 , and the differences in total.count at each time do not greatly exceed what might be expected on the basis of measurement error alone.

The coefficient of variation of repeated differential counts is approximately $14 \%$. Since the total erythrocyte precursor count is the produce of the total cell count and the differential count, its coefficient of variation is approximately $\left(\sqrt{7^{2}+14^{2}}\right) \%$ or about $16 \%$. For counts in the neighborhood of 80 , the standard error is thus approximately 13 , and the differences in erythrocyte precursor total counts are appreciably larger than the estimated magnitude of the measurement error.

\section{SUMMARY}

The effects of 5 different types of sera upon erythropoiesis in bone marrow tissue culture, using a modification of the Mackeness and Smith chamber, have been tested. Eagle's medium and test serum in a 2:1 proportion were used as nutrient medium. Total and differential cell counts were done after $0,12,24$, and, in one case, $36 \mathrm{hrs}$. of incubation at $37^{\circ} \mathrm{C}$. Cultures sustained with normal rat serum showed a decrease in the number of erythrocyte precursors which is linear and predictable. Cultures grown in serum from rats rendered anemic by bleeding showed a marked increase in erythropoiesis after $12 \mathrm{hrs}$. of incubation. The same effect was seen in cultures grown with serum from rats that had been given cobaltous chloride $(25 \mu \mathrm{M} / 100 \mathrm{~g}$ body wt) $10 \mathrm{hrs}$. before the removal of the serum. When cobalt ion was added to normal serum in vitro to the same final concentration as found in the serum from injected rats, the resultant combination had no effect on erythropoiesis. When serum from rats rendered polycythemic was used, a marked decrease in erythropoiesis was noted after $12 \mathrm{hrs}$. of incubation.

These experiments give further evidence of the existence of a humoral factor(s) (erythropoietin) that stimulates erythropoiesis, and, in addition, establish that the substance(s) 
circulates in a form that is readily available to the bone marrow. The stimulatory effect of cobalt on erythropoiesis is through this hormone. There is also evidence that erythropoietin is present in serum from normal animals and that the amount is decreased in serum from animals rendered polycythemic by transfusion.

\section{ACKNOWLEDGMENTS}

The authors gratefully acknowledge the efforts of Dr. Paul Meier of the University of: Chicago Department of Statistics in preparing the statistical analyses of these experiments and Dr. William Barclay of the University of Chicago School of Medicine, for his instruction in the construction and use of the culture chambers.

\section{LITERATURE CITED}

1. Plzak, L: F., W. Fried, L. O. Jacobson, and W. F. Bethard. J. Lab. Clin. Med., 46: $671,1955$.

2. Erslev, A. S. Blood, 8:349, 1953.

3. Erslev, A. J., P. H. Lavietes, and G. van Wagenen: Proc. Soc. Exp. Biol. Med., 83: $548,1953$.

4. Hodgson, G., and J. Toha. Blood, 9:299, 1954.

5. Gordon, A. S., S. J. Piliero, W. Kleinberg, and H. H. Freedman. Proc. Soc. Exp. Biol. Med., 86:255, 1954 .

6. Linman, J. W., and F. H. Bethell. Blood, 11:310, 1956.

7. Reissmann, K. R. Blood, $.5: 372,1950$.

8. Stohlman, F., and G. Brecher. J. Lab. Clin. Med., 49:890, 1957.

9. Goldwasser, E., L. O. Jacobson, W. Fried, and L. Plzak. Science, 125:1085, 1957.

10. Jacobson, L. O., E. Goldwasser, L. F. Plzak, and W. Fried. Proc. Soc. Exp. Biol. Med., $94: 243,1957$.

11. Fried, W., L. Plzak, L. O. Jacboson, and E. Goldwasser. Proc. Soc. Exp. Biol. Med., $94: 237,1957$.

12. Matoth, Y., N. Biezunski, and G. Szabo. J. Lab. Clin. Med., 51:420, 1958.

13. Mackeness, G. B. J. Path. Bact., 64:429, 1952.

14. Eagle, H. J. Biol. Chem., 214:839, 1955.

15. Eagle, H. J. Exper. Med., 102:595, 1955.

16. Eagle, H., V. I. Oyama, M. Levy, C. L. Horton, and R. Fleishman. J. Biol. Chem., 218:607, 1956 :

17. Osgood, E. E., and J. H. Brooke. Blood, 10:1010, 1955.

18. Goldwasser, E., L. O. Jacobsón, W. Fried, and L. F. Plzak. Blood, 13:55, 1958.

19. Laforet, M. T., and E. D. Thomas. J. Biol. Chem., 218:595, 1956. 


\section{STUDIES ON ERYTHROPOIESIS. XI. RETICULOCYTE RESPONSE OF \\ TRANSFUSION-INDUCED POLYCYTHEMIC MICE TO ANEMIC \\ PLASMA FROM NEPHRECTOMIZED MICE AND PLASMA \\ FROM NEPHRECTOMIZED RATS EXPOSED TO \\ LOW OXYGEN ${ }^{*}$}

\section{By}

L. O. Jacobson, E. K. Marks, E. O. Gaston, and E. Goldwasser

In publications by Jacobson, Goldwasser et al.,$^{1,2,3}$ data are presented suggesting that the kidney may be the site of elaboration of erythropoietin(s). Mirand and Prentice 4 and Erslev ${ }^{5}$ offer data to the contrary.

Plasma erythropoietic activity is demonstrable by a number of different but related assay methods, $6,7,8$ but the basic substance(s) has not been characterized chemically; nor have assay methods been sufficiently refined to yield information revealing whether a single substance or group of substances is involved. Erythropoietic activity can be demonstrated readily in the plasma of normal rats and rabbits subjected to cobalt ion, anemic anoxia, or hypoxic anoxia. ${ }^{9}$ In our hands, bilateral nephrectomy regularly abolishes this capacity. $1,2,3$

This paper describes studies of the capacity of mice to produce erythropoietin in response to anemic anoxia and cobalt ion. Whether bilateral nephrectomy in mice significantly influences the response to these stimuli is also considered. The plasma or plasma extracts from nephrectomized animals were assayed in transfusion-induced polycythemic mice. In addition, data are presented on the effect of bilateral nephrectomy on the capacity of the rat to produce a measurable increase in erythropoietin in response to hypoxic anoxia, using not only polycythemic mice for assay, but starved and hypophysectomized rats as well.

\section{MATERIAL AND METHODS}

CF No. 1 female and C57BL/6Jax mice of both sexes were used in the experiments designed to study the reticulocyte response in transfusion-induced polycythemic mice following the injection of "anemic" mouse plasma or other plasma preparations. SpragueDawley male rats, weighing from 200 to $300 \mathrm{~g}$, were used as donors for the low-oxygen rat-plasma experiments. All plasma injections were given to the recipient mice intravenously by tail vein, intraperitoneally, or subcutaneously in 0.5 -cc amounts on 4 or 5 successive days. Recipient rats received subcutaneously a $2-c c$ dose on 2 successive days. $\mathrm{Fe}^{59}$ incorporation was determined 8,16 , or $24 \mathrm{hrs}$. after the last injection.

\footnotetext{
${ }^{*}$ A revision of this paper has been accepted for publication in Blood.
} 
cessive days.

Preparation of the plasma. "Anemic" mouse plasma was obtained from adult mice with a bleeding-induced anemia, from mice following 3 or 4 subcutaneous injections of 1.25 to $1.50 \mathrm{mg}$ of phenylhydrazine hydrochloride given over a period of 6 days, or from female mice during the last trimester of pregnancy. Blood from the carotid arteries was collected in heparin immediately after cervical fracture when the hematocrit was circa 30 per cent. The plasma was separated by centrifugation and stored immediately at $-17^{\circ} \mathrm{C}$. "Cobalt plasma" was prepared by injecting adult mice with $5 \mu \mathrm{M}$ cobaltous chloride ( $5 \mu \mathrm{M}$ in $0.5 \mathrm{cc}$ of saline) subcutaneously 8 or 9 hours before collecting the blood for plasma. Plasma from nephrectomized and sham-operated mice was collected 10 hours after surgery. Normal mouse plasma was obtained from normal untreated adult mice. Starved-rat plasma was collected from animals that had been deprived of food for 4 days, but were allowed water ad libitum. Plasma was also collected frum rats after exposure to low oxygen at a simulated altitude of $21,500 \mathrm{ft}$. for 8,16 , or 24 hours. Bilateral nephrectomy or bilateral ureter ligation was performed immediately before the animals were placed in low oxygen. Plasma for control purposes was obtained from unoperated rats exposed similarly to low oxygen and from normal rats.

Operative procedures. Bilateral nephrectomy was performed on mice (with a phenylhydrazine-induced anemia) and rats under Nembutal anesthesia. The kidneys were removed by making a median abdominal incision; tying the renal blood vessels with one suture; and removing the kidney from its capsule, leaving the adrenal gland intact. The incision was closed with silk. Sham operations were performed in which the capsule of the kidney was peeled off, but the kidney was not removed.

Preparation of polycythemic recipients. CF No. 1 mice weighing $23 \mathrm{~g}$ and C57BL/6Jax, 18 to $20 \mathrm{~g}$, were made polycythemic by intraperitoneal injections of 75 to 80 per cent concentration of washed homologous red cells suspended in saline. The suspension was given in 0.5 -ccamounts on 3 successive days and once again 2 days later. Seven days after the last injection of red cells, when the hematocrits were circa 70 per cent and no reticulocytes were found in the peripheral blood, the mice were used as recipients for the various plasma injections. Hematocrit determinations were made on a micro-hematocrit centrifuge, using heparinized capillary tubes. Reticulocytes were counted by the direct-smear method, using brilliant cresyl blue without counterstain. When no reticulocytes were found in 100,000 red cells, the values were recorded as 0.000 per cent. Blood for hematocrit and reticulocyte determinations was drawn from the tail vein.

Polycythemic recipients of mouse plasma. In the first experiment, polycythemic recipients were divided into groups of 7 or more animals each. The animals in groups 1 and 2 served as controls, receiving saline and normal plasma, respectively. Those in group 3 received anemic plasma; in group 4, plasma from mice nephrectomized following a phenylhydrazine-induced anemia; and in group 5, plasma from sham-operated anemic mice (Figures 1-4).

The second experiment was similar to the first except that the mice in group 4 re- 

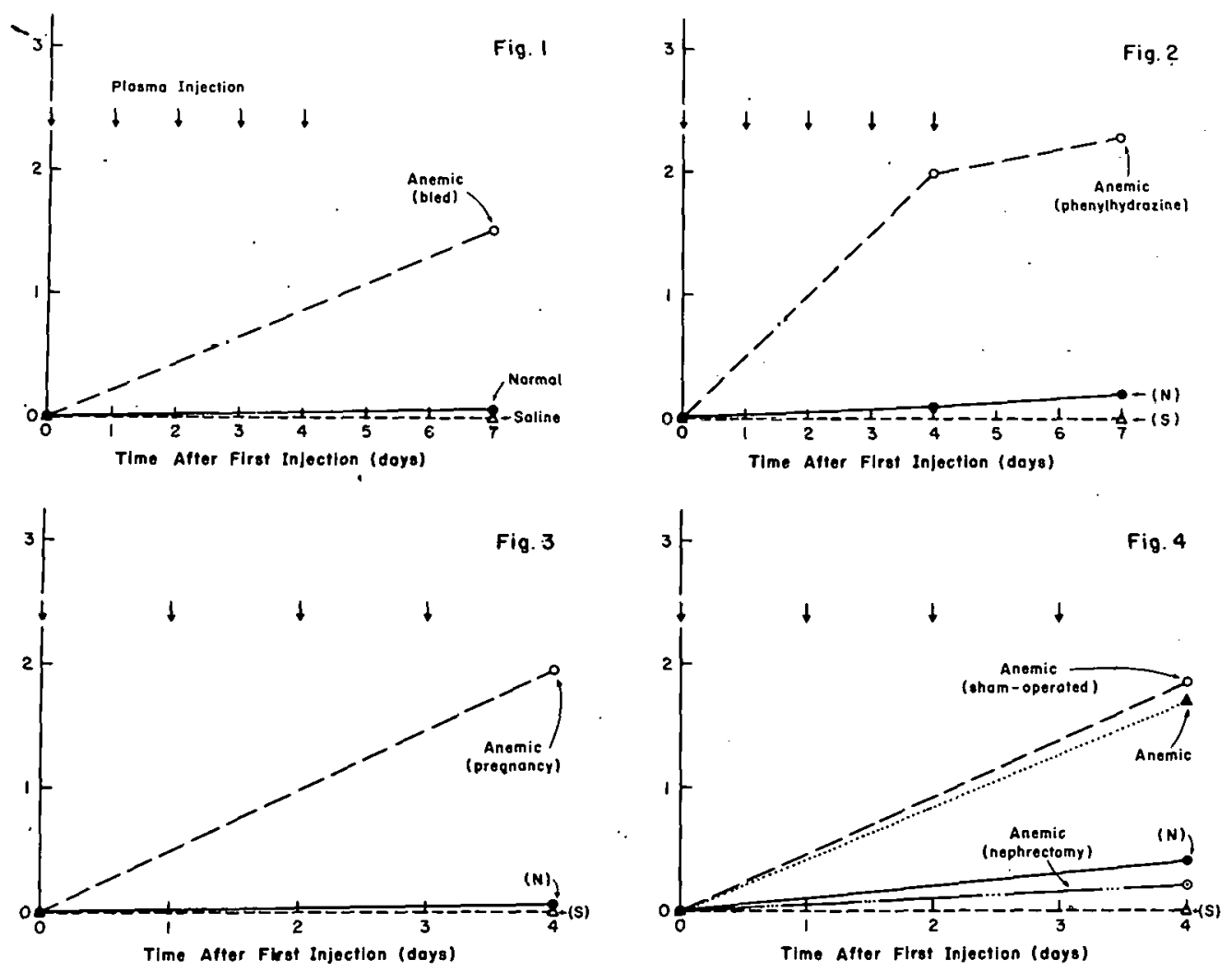

Figure 1. Effect of 5 intravenous injections of plasma from CF No. 1 mice with a bleeding-induced anemia on the reticulocytes of CF No. 1 mice with a transfusion-induced polycythemia.

Figure 2. Effect of 5 intraperitoneal injections of plasma from C57BL/6 Jax mice with a phenylhydrazine-induced anemia on the reticulocytes of C57BL/6 Jax mice.

Figure 3. Effect of 4 subcutaneous injections of plasma from CF No. 1 pregnant mice obtained during the last trimester on the reticulocytes of CF No. 1 mice with a transfusion-induced polycythemia.

Figure 4. Effect of 4 subcutaneous injections of mouse plasma from anemic nephrectomized, sham-operated and anemic mice on the reticulocytes of CF No. 1 mice with a transfusion-induced polycythemia.

(S) refers to saline injection.

(N) refers to injections of normal plasma.

ceived plasma from mice that had received cobaltous chloride, and those in group 5, plasma from normal mice with $0.042 \mu \mathrm{M}$ per $\mathrm{ml}$ of cobaltous chloride added (this amount was calculated as the amount of free cobaltous chloride present in the cobalt mouse plasma) (Figure 5).

In 3 separate studies, polycythemic mice were given plasma from rats exposed to low oxygen. These 3 experiments differed only in the length of time the rats were exposed to low $\mathrm{O}_{2}(8,16$, or 24 hours). Animals in groups 1 and 2 again served as controls, receiving 
saline and normal plasma, respectively; those in group 3 received plasma from normal rats exposed to low $\mathrm{O}_{2}$; those in group 4, plasma from animals with a bilateral nephrectomy and exposure to low $\mathrm{O}_{2}$; and those in group 5, plasma from animals with ureters ligated and low $\mathrm{O}_{2}$ exposure. Animals in group 6 were given an extract of anemic plasma known to be active (Figure 5). In still another experiment, group 3 mice received plasma from starved rats, and group 4 mice received plasma from rats exposed to low $\mathrm{O}_{2}$ for 8 hours (Figure 6).

Histology. Histologic studies were confined to the mice given plasma from rats exposed to low $\mathrm{O}_{2}$ for 24 hours after nephrectomy. On the day following the 4 th injection, the mice were sacrificed immediately after the hematocrit and reticulocyte determinations were completed. This made it possible to correlate studies of the blood-forming tissue with evidence of erythropoiesis as judged by reticulocytes in the peripheral blood and the incorporation of $\mathrm{Fe}^{59}$ into the red cells. The tissues were fixed in Zenker-Formol, and then embedded in nitrocellulose, cut at $6 \mu$ and stained with hematoxylin, eosin, and azure.
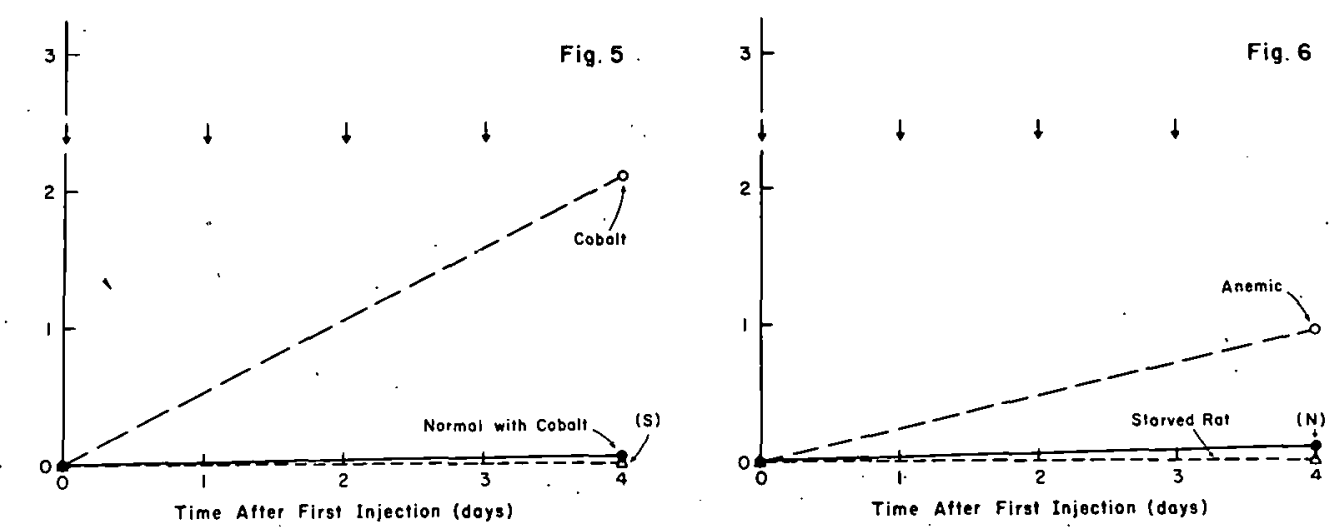

Figure 5. Effect of 4 subcutaneous injections of plasma from cobaltinjected mice as compared with that of normal mouse plasma with cobalt added on the reticulocytes of mice with a transfusion-induced. polycythemia.

Figure 6. Effect of 4 subcutaneous injections of plasma from rats starved for 4 days compared with that of plasma from rats subjected to a simulated altitude of 21,500 feet for 8 hours.

(S) refers to saline injection. (N) refers to injections of normal plasma.

\section{RESULTS}

The reticulocyte values of CF No. 1 female mice with a transfusion-induced polycythemia increased from 0.0 per cent to 1.56 per cent by 4 days after the first daily intravenous injection of $0.5 \mathrm{cc}$ of plasma obtained from mice of the same strain with an anemia induced by bleeding, and rose to 1.69 per cent in mice given subcutaneous injections of $0.5 \mathrm{cc}$ of plasma from mice with a phenylhydrazine-induced anemia. The reticulocyte values of mice that received normal plasma rose to only 0.01 per cent, while mice receiving saline remained essentially reticulocyte-free during this period (Figure 1).

The reticulocyte values of C57BL/6Jax "polycythemic" mice likewise increased from 
0.0 per cent to 2.0 per cent by 4 days after the administration of anemic plasma obtained from C57BL/6 Jax mice with a phenylhydrazine-induced anemia, and mice receiving normal plasma responded with 0.2 per cent reticulocytes (Figure 2).

In a separate but similar experiment, anemic plasma obtained from CF No. 1 mice during the last trimester of pregnancy was used (hematocrit, circa 30 per cent). By 4 days after the first of 4 injections given on successive days, the reticulocyte values of polycythemic mice receiving anemic plasma from pregnant mice were 2.1 per cent as compared with 0.01 per cent in mice that received normal plasma and 0.0 per cent in mice that received saline (Figure 3 ).

The reticulocyte values of CF No. 1 polycythemic mice injected subcutaneously on 4 successive days with $0.5 \mathrm{cc}$ of plasma obtained from mice 8 or 9 hours after a single injection of cobaltous chloride increased to 2.1 per cent by 4 days. No change in reticulocyte values was found in polycythemic mice that received 4 injections of normal plasma with cobalt added (0.042 $\mu \mathrm{M}$.per $\mathrm{ml}$ ) (Figure 5 ).

Plasma obtained from mice with a phenylhydrazine-induced anemia, 10 hours after sham nephrectomy, increased the reticulocyte values in polycythemic mice to 1.97 per cent, whereas plasma from anemic-nephrectomized and normal mice increased the reticulocyte values to only 0.26 and 0.4 per cent, respectively (Figure 4).

No reticulocyte response was found in mice that were given starved-rat plasma (Figure 6 ). The reticulocyte response, however, in polycythemic mice that received plasma from rats exposed to low oxygen for 8,16 , or 24 hours was respectively, $0.9,1.7$, and 1.66 per cent by 4 days after the first subcutaneous injection. Plasma from rats that were nephrectomized before similar subjection to low $\mathrm{O}_{2}$ produced a slight reticulocyte response to polycythemic mice. By 4 days, the reticulocyte values in the recipient animals that received nephrectomized low $-\mathrm{O}_{2}$ rat plasma were $0.183,0.114$, and 0.006 per cent, respectively. Polycythemic mice that received normal rat plasma or saline remained essentially reticulocyte-free (Figure 6). The plasma used in this latter experiment was assayed in hypophysectomized and starved rats, and as shown in Table 1, showed no erythrocytic activity. These data are included to permit a comparison with the histologic findings shown in Figure 7.

The histologic difference in the spleens of mice that received erythropoietin-rich plasma and plasma from normal mice has been described in detail in a previous report. ${ }^{10}$ In the present experiments, plasma was given to reticulocyte-free polycythemic mice in a series of 4 injections of $0.5 \mathrm{ml}$ each. Erythropoietic activity in the red pulp was marked in the spleens of mice that received anemia plasma or plasma from cobalt-injected mice. The red pulp in spleens from mice injected with normal plasma or saline was less populated with erythropoietic tissue or was sparsely cellular. The spleens of mice that received plasma from nephrectomized rats exposed to low oxygen revealed no erythropoietic proliferation in the red pulp, whereas the spleens from mice that received plasma from rats with the ureters ligated or from unoperated controls exposed to low oxygen were observed to be packed solidly with erythropoietic tissue in the red pulp (Figure 7). 
Table 1

A. EFFECT OF PLASMA FROM NORMAL UNOPERATED, NEPHRECTOMIZED AND URETER-LIGATED RATS EXPOSED TO A SIMULATED ALTITUDE OF 21,500 FEET FOR 8, 16, OR 24 HOURS ON THE $\mathrm{Fe}^{59}$ UPTAKE IN STARVED AND HYPOPHYSECTOMIZED RATS.

B. EFFECT ON THE RETICULOCYTES OF MICE WITH A TRANSFUSION-INDUCED POLYCYTHEMIA.

\begin{tabular}{|c|c|c|c|c|c|c|c|c|c|c|c|}
\hline & & & & & & A & & & & $B$ & \\
\hline & $\begin{array}{l}\mathrm{Fe}^{59} \text { ur } \\
\text { in star }\end{array}$ & $\begin{array}{l}\text { ake }(\%) \\
\text { ed rats }\end{array}$ & & & $\underset{\text { hypophys }}{\mathrm{Fe}^{59}}$ & $\begin{array}{l}\text { take }(\%) \\
\text { tomized } r\end{array}$ & & & $\begin{array}{r}\text { Reticul } \\
\text { in polycy }\end{array}$ & $\begin{array}{l}\text { cytes }(\%) \\
\text { lemic mice }\end{array}$ & \\
\hline $\begin{array}{l}\text { Time in } \\
\text { low } 0_{2} \\
\text { (hours) }\end{array}$ & $\begin{array}{c}\text { Normal } \\
\text { unoper- } \\
\text { ated }\end{array}$ & $\begin{array}{c}\text { Nephrec- } \\
\text { tomy }\end{array}$ & $\begin{array}{l}\text { Ureters } \\
\text { ligated }\end{array}$ & $\begin{array}{l}\text { Time in } \\
\text { low } 0_{2} \\
\text { (hours) }\end{array}$ & $\begin{array}{c}\text { Normal } \\
\text { unoper- } \\
\text { ated }\end{array}$ & $\begin{array}{c}\text { Nephrec- } \\
\text { tomy. }\end{array}$ & $\begin{array}{l}\text { Ureters } \\
\text { ligated }\end{array}$ & $\begin{array}{l}\text { Time in } \\
\text { low } 0_{2} \\
\text { (hours) }\end{array}$ & \begin{tabular}{|c|}
$\begin{array}{c}\text { Normal } \\
\text { unoper- } \\
\text { ated }\end{array}$ \\
\end{tabular} & $\begin{array}{l}\text { Nephrec- } \\
\text { tomy }\end{array}$ & $\begin{array}{l}\text { Ureters } \\
\text { ligated }\end{array}$ \\
\hline 8 & 11.5 & 4.3 & 9.8 & -- & -- & -- & -- & 8 & 0.9 & 0.183 & 0.7 \\
\hline 16 & 8.6 & 4.5 & 9.6 & 16 & 22.5 & 5.0 & 17.5 & 16 & 1.7 & 0.114 & 1.38 \\
\hline 24 & 14.7 & 4.7 & 14.6 & -- & -- & -- & -- & 24 & 1.6 & 0.006 & 1.26 \\
\hline None* & 4.6 & -- & -- & None* & 4.2 & & & None* & 0.001 & -- & -- \\
\hline
\end{tabular}

* Plasma from normal untreated rats not exposed to low oxygen. Recipients received plasma from normal rats not exposed to low oxygen. 

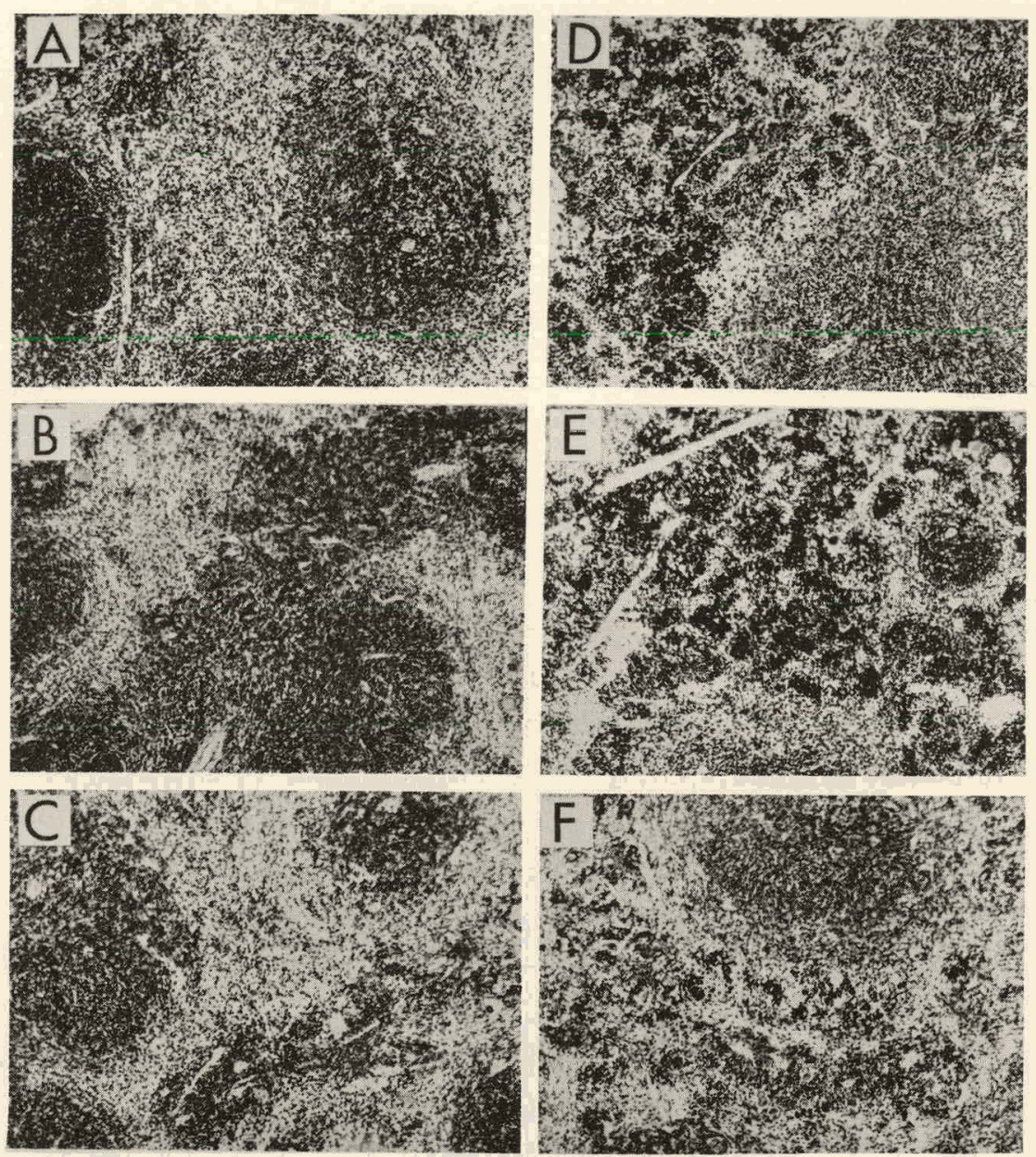

Figure 7. Histologic effect of 40.5 -cc injections of rat plasma on splenic erythropoiesis in mice with a transfusion-induced polycythemia. Tissues were taken for study 4 days after the first injection of plasma.

A. Spleen of normal plasma-injected mouse. Red pulp is devoid of erythropoietic foci.

B. Spleen of mouse injected with plasma from nephrectomized rat. Red pulp is sparsely cellular and there are no islands of erythropoiesis apparent.

C. Spleen of mouse injected with mouse plasma from nephrectomized mouse exposed to a simulated altitude of 21,500 feet for 24 hours. Red pulp is very sparsely populated and no islands of erythropoiesis are seen.

D. Spleen of mouse given plasma from unoperated rat exposed to a simulated altitude of 21,500 feet for 24 hours. Marked erythropoietic activity in the red pulp and a moderate reduction in lymphopoietic cells in the white pulp.

E. Spleen from mouse injected with a plasma extract known to have erythropoietic activity. Extreme erythropoietic activity in the red pulp.

F. Spleen of mouse that received plasma from rat with ureters tied and exposed to a simulated altitude of 21,500 feet for 24 hours. Red pulp shows numerous islands of erythropoiesis. 


\section{DISCUSSION}

Present methods of assay for erythropoietin(s) are at best semi-quantitative. Of the available assay preparations, we found the transfusion-induced polycythemic mouse to be the most reliable, and we use it routinely to check results obtained by other assay means. In a sense, the polycythemic mouse is ideal for bioassay because erythropoietin production is presumably shut off by a "nontoxic" physiologic mechanism (increased $\mathrm{O}_{2}$ supply in the presence of a normal $\mathrm{O}_{2}$ demand). Consequently, erythropoiesis drops for all practical purposes to zero as judged by the absence of reticulocytes in the peripheral blood and the absence of recognizable erythroblasts in the blood-forming tissue. Thus, any exogenous erythropoietin(s) (if one assumes that an erythropoietin is required to initiate erythropoiesis) must initiate erythropoiesis from the reticulum itself, from primitive erythroblasts, or from "multipotential" blast forms that are available in the marrow; perhaps from all 3. The observed response to anemic plasma culminates in the appearance of recognizable erythroblast forms which produce red cells. At this time, we cannot say which of these possibilities obtains or whether, in fact, all are operating. At any rate, either with anemic anoxic plasma, cobalt ion, cobalt plasma, or extracts made from known active "anemic" plasma, erythropoiesis proceeds from none at all to a hyperplastic erythroblastic stage in 3 to 4 days. Histologically, this transition appears to be orderly, and the various forms and maturation stages appear quite normal.

The questions that need clarification, insofar as the data presented in this paper are concerned, are: Can erythropoiesis be initiated directly in the polycythemic mouse by "nonspecific material?" Is there any evidence that erythropoietin (s) is present in the system?

These questions have real significance in attempting to assess the effect of bilateral nephrectomy on the capacity of rats or rabbits to respond to anemic anoxia, cobaltous chloride, or hypoxic anoxia. The reticulocyte values from groups of mice given plasma derived from bilateral nephrectomized rats exposed to hypoxic anoxia for 8,16 , or 24 hours were $0.183,0.114$, and 0.006 per cent, respectively. In previous experiments, similar values were found, but not consistently. On histologic examination, there was no evidence of erythroblastic proliferation in the bone marrow or spleens of these animals. This of course does not mean that no erythroblasts exist in the hematopoietic tissues. The same plasma assayed in these experiments in polycythemic mice gave negative results when assayed in normal rats, starved rats, or hypophysectomized rats, using $\mathrm{Fe}^{59}$ uptake as the criterion. In fact, in a previous communication, ${ }^{10}$ it is shown that when erythropoiesis is below 0.5 per cent, as measured by the number of reticulocytes in the peripheral blood, $\mathrm{Fe}^{59} \mathrm{red}$ cell incorporation is found to be about 5 per cent. This is within the range of values that we find routinely in polycythemic rats, mice, or starved or hypophysectomized rats given saline or normal plasma ${ }^{8,10}$ and which we consider a normal control baseline value.

If the se minimal reticulocyte values (about 0.2 per cent or less) found in the polycythemic mice in response to plasma from nephrectomized rats or rabbits that have been subjected to anemic anoxia, cobalt ion, or hypoxic anoxia can be considered to be the re- 
sult of the introduction of erythropoietin(s) into the system, then it would be necessary to state that erythropoietin production can occur in the absence of the kidneys. Accepting this for purposes of discussion, then two possibilities may be considered; namely, that 1) the kidneys do not produce erythropoietin and the reduced production in nephrectomized animals is a result of the toxicity, and 2) in the absence of the kidneys another site has the capacity to respond with minimal erythropoietin production in response to a severe stimulus (hypoxic anoxia). This latter concept might be considered analogous to the production of other substances such as androgens and estrogens. These hormones are made principally in the gonads, but synthesis on a small scale (roughly less than 10 per cent of normal production) may occur in the adrenal. On the other hand, $\operatorname{Erslev}^{5}$ may well be right in his suggestions that erythropoiesis in the normal, steady state is under the control of erythropoietin produced in some as yet unknown site, and that in the presence of renal disease, with uremia or after bilateral nephrectomy, some toxic effect interferes with the normal production or utilization, or both.

The failure to find an increased titer in bilaterally nephrectomized rats or rabbits may be due merely to a poisoning of the site of production which interferes with synthesis of the erythropoietin molecule in a structural and functional sense. As a matter of fact, one could take the data referred to above (reticulocyte values of $0.183,0.114$, and 0.006 per cent in polycythemic mice in response to plasma from nephrectomized rats exposed to low $\mathrm{O}_{2}$ for 8,16 , and 24 hours; respectively) and suggest that the number of reticulocytes in response in time to the plasma assayed was the result of the increasing toxicity caused by nephrectomy; that is, erythropoietin production in response to anoxia was drastically reduced even by 8 hours, and, for all practical purposes, eliminated by 24 hours. Further evidence in support of this thesis is the fact that after bilateral ureter ligation; the response to anemic anoxia or hypoxic anoxia in terms of erythropoietin titer may diminish by 24 hours as compared with 12 hours. ${ }^{11}$

It is worthy of note that the plasma of rats starved for 4 days contained no erythropoietic activity when assayed in the polycythemic mouse. This was to be expected since the starved rat in our hands is sensitive to plasma with erythropoietic activity. ${ }^{8}$ We have assumed this indicated a reduced erythropoietin titer in the plasma of starved rats.

It is interesting that increased erythropoietic activity is found in the plasma of the mouse during the last trimester of pregnancy. These mice are almost universally anemic in late pregnancy as described in the accompanying paper, Part XII. This finding substantiates the report of Contopoulos et al. ${ }^{12}$

\section{SUMMARY AND CONCLUSIONS}

Transfusion-induced polycythemic mice have been used to assay erythropoietic activity in plasma derived from mice and rats subjected to various stimuli and experimental procedures.

1. Anemic, anoxic, or cobalt mouse plasma increased erythropoiesis from the zero baseline to about the normal range after 4 daily $0.5-\mathrm{cc}$ injections. No significant effect is 
observed from the same number of injections of normal rat or mouse plasma or normal saline. Similarly, plasma from rats starved 4 days had no erythropoietic activity, but erythropoietic activity was present in the plasma of pregnant mice during the last trimester of pregnancy.

2. Plasma from mice made anemic by phenylhydrazine and then subjected to bilateral nephrectomy contained slight erythropoietic activity $(0.2$ per cent or less reticulocytes, comparable to normal control plasma). The plasma of sham-operated anemic animals had considerably more erythropoietic activity ( 2.0 per cent). The plasma was collected for assay 10 hours after the operative procedures.

3. Plasma from nephrectomized rats exposed to hypoxic anoxia for 8,16 , or 24 hours, had slight erythropoietic activity when measured by the peripheral reticulocyte response of the recipients $(0.183,0.114$, and 0.006 per cent reticulocytes, respectively). (The same plasma had no erythropoietic activity measured by the $\mathrm{Fe}^{59}$ red cell incorporation response in hypophysectomized rats.) Plasma from rats subjected to bilateral ureter ligation and similarly exposed for an erythropoietic activity $(0.7,1.38$, and 1.25 per cent reticulocytes, respectively), comparable with that of the plasma from normal rats exposed to hypoxic anoxia $(0.9,1.7$, and 1.66 per cent, respectively). This low and inconstant erythropoietic activity in the plasma of nephrectomized.mice and rats subjected to anemic or hypoxic anoxia is more or less comparable with the response occasionally produced by normal plasma. We are, therefore, disinclined to consider the data as evidence against the renal origin of erythropoietin, and the alternative possibilities are discussed.

\section{LITERATURE CITED}

1. Jacobson, L. O., E. Goldwasser, .W. Fried, and L. Plzak. Nature, 179:633, 1957.

2 . Trans. of the Assoc. of Amer. Physicians, 70,305, 1957.

3. Goldwasser, E., W. Fried, and L. O. Jacobson. J. Lab. Clin. Med., 52:375, 1958.

4. Mirand, E. A., and T. C. Prentice. Proc. Soc. Exp. Biol. Med., 96:49, 1957.

5. Erslev, A. Arch. of Int. Med., 101:407, 1958.

6. Blood, 8:349, 1953.

7. Stohlman, F., Jr., and G. Brecher. Proc. Soc. Exp. Biol. Med., 91:1, 1956.

8. Fried, W., L. Plzak, L. O. Jacobson, and E. Goldwasser. Proc. Soc. Exp. Biol. Med., $92: 203,1956$.

9. Goldwasser, E., L. O. Jacobson, W. Fried, and L. Plzak. Blood, 13:55, 1958.

10 . Proc. Soc. Exp. Biol. Med., 94:243, 1957.

1.1. Fried, W., and E. Goldwasser. To be published.

12. Contopoulos, A. N., D. C. Van Dyke, and M. E. Simpson. Proc. Soc. Biol. Med., 93: 424, 1956. 


\section{STUDIES ON ERYTHROPOIESIS. XII. THE EFFECT OF TRANSFUSION - INDUCED POLYCYTHEMIA IN THE MOTHER ON THE FETUS*}

By

\section{O. Jacobson, E. K. Marks, and E. O. Gaston}

Transfusion-induced polycythemia in mice reduces erythropoiesis to zero, as judged by the number of reticulocytes in the peripheral blood, the incorporation of $\mathrm{Fe}^{59}$ into the red blood cells, and by histologic changes in the blood-forming tissue. ${ }^{1}$ Polycythemic mice respond to the injection of anemic or cobalt plasma by a restoration of erythropoiesis to the normal range. ${ }^{2}$ These observations suggest that the hormone controlling red cell pro- duction (erythropoietin) is reduced drastically or absent in the se mice after the polycythemia has been established.

With these observations in mind, we wondered what would happen to fetal erythropoiesis if transfusion-induced polycythemia were established in normal mice that were then mated, the polycythemia being maintained throughout pregnancy. Several other questions were considered. Would erythropoiesis fail to begin in the embryo because no erythropoietin would be available by placental transfer to the embryo? It has been reported that the normal pregnant rat has a plasma erythropoietin content that is above normal, ${ }^{3}$ and that fetal and cord blood likewise has a higher plasma erythropoietin titer. ${ }^{4,5}$ It is not known whether erythropoietin passes from the maternal to the fetal circulation or vice versa. Since erythropoiesis begins in the mouse embryo at about 10 days, it was possible that erythropoiesis might be delayed in these embryos until some fetal tissue began to make erythropoietin independently of the mother. If the embryo were able to begin manufacture of erythropoietin, would the amount be sufficient to bring the peripheral hematologic values to the normal range at term? If the fetus were able to maintain erythropoiesis by virtue of its own erythropoietin production or by some other mechanism, would fetal erythropoietin pass into the maternal circulation and produce reticulocytosis in the polycythemic mother?

\section{MATERIALS AND METHODS}

\section{Preparation of Animals}

Young, adult CF No. I female mice, ${ }^{\dagger}$ weighing about $23 \mathrm{~g}$, were given repeated 0.5 -cc intraperitoneal injections of washed homologous red cells until the hematocrit reached between 60 and 75 per cent. When the mice were reticulocyte-free, they were mated. Hematocrit and reticulocyte determinations were made at frequent intervals-usually every oth-

\footnotetext{
* Text of a paper that has been submitted for publication in Blood.

tApproximately 150 pregnant mice were used in these studies.
} 
er day-and further red cell transfusions were given intraperitoneally or intravenously as needed to maintain the hematocrit above 60 per cent. The maternal peripheral blood was examined for reticulocytes at the approximate time of conception, at 3 consecutive 3-day intervals, and then every day or alternate one, with final reticulocyte and hematocrit determinations being made at the time of spontaneous delivery at term or at the time of cesarean section. Hemoglobin and erythrocyte values were obtained less frequently.

In other experiments, red cell transfusions were initiated and polycythemia was produced and maintained, beginning 1 and 5 days after mating. In other respects, the general plan outlined above was followed. Knowing that erythropoiesis began at about 10 days, it seemed advisable to confine our studies largely to mice that were polycythemic before mating or to those that were made polycythemic and essentially reticulocyte-free before the 7- to 9-day period of gestation.

Blood values for the 18-day-old fetus were obtained immediately after cesarean sec-. tion, and for the newborn, within 24 hours after spontaneous delivery. These consisted routinely of reticulocyte and micro-hematocrit determinations; less frequently of red cell and hemoglobin determinations.

Controls consisted of normal mice of the same age and strain. These mice were allowed to mate, and control blood counts were performed as soon as conception was established, as judged by the copulation plug in the vagina. Hematologic studies paralleling those of the transfusion-induced polycythemic, pregnant mothers were carried out throughout pregnancy, and after spontaneous or cesarean delivery. Hematologic studies on the fetuses or newborn mice were carried out as described above.

The mothers were weighed at the beginning of the experiment, at frequent intervals during pregnancy, and immediately before and after delivery. The fetuses or newborn mice were weighed individually, as was the liver of each after dissection (wet weight).

Histologic Studies

At least 2 polycythemic and 2 normal mice were sacrificed at $9,10,12,14,15,16$, 18 , and 19 days after conception to permit comparison of the histologic changes in the blood-forming tissue (bone marrow and spleen). Likewise, the embryos of these mice were also sacrificed. The maternal and fetal tissue (or whole embryo) was fixed in ZenkerFormol and then embedded in nitrocellulose, cut at $6 \mu$ and stained with hematoxylin, eosin, and azure. Representative maternal and fetal tissue sections were stained for iron by a method described by Beutler et al. ${ }^{6}$

Special Studies

Incorporation of $\mathrm{Fe}^{59}$ into the red blood cells of mother and fetus or newborn. Normal and polycythemic pregnant mice were injected with approximately $1 \mu \mathrm{c}$ of $\mathrm{Fe}^{59} \mathrm{cit}$ rate on the 15 th day of pregnancy, and on the 18 th or 19th day of pregnancy. Eighteen hours after injection, the total-body uptake of iron was determined. The mice were then anesthetized with Nembutal. Cesarean sections were performed, and the iron uptake of each fetus was measured. The measurements were made by means of a whole-body technique described previously. ${ }^{7}$ The fetal-body content of $\mathrm{Fe}^{59}$ was expressed as per cent of total- 
body count in the mother.

Placental red cell transfer studies. Homologous red cells labeled with $\mathrm{Cr}^{51}$ were injected intravenously and/or intraperitoneally into normal and polycythemic pregnant mice during the last trimester of pregnancy. Maternal and fetal.blood (or the entire fetus) was counted in a scintillation well counter. The results are shown in Table 1.

Table 1

AMOUNT OF RADIOACTIVITY IN WHOLE BLOOD FROM NORMAL AND POLYCYTHEMIC PREGNANT MICE, THE NEWBORN, AND THE FETUSES FOLLOWING THE INTRAVENOUS AND/OR INTRAPERITONEAL INJECTION OF $\mathrm{Cr}^{51}$-LABELED HOMOLOGOUS RED CELLS.

\begin{tabular}{|c|c|c|c|c|c|}
\hline \multirow{2}{*}{\multicolumn{2}{|c|}{$\begin{array}{c}\text { Time of } \\
\text { Cr } 51 \text { injection } \\
\text { (days of gestation) }\end{array}$}} & \multirow{3}{*}{$\begin{array}{c}\text { Time of sampling } \\
\text { after } \mathrm{Cr}^{51} \\
\text { (hours) }\end{array}$} & \multirow{3}{*}{$\begin{array}{c}\text { Number fetuses } \\
\text { or } \\
\text { offspring counted }\end{array}$} & \multicolumn{2}{|c|}{ Radioactivity (cpm) } \\
\hline & & & & Fetuses & $\begin{array}{c}\text { Mother } \\
(0.1 \mathrm{cc} \text { blood })\end{array}$ \\
\hline \multirow{7}{*}{ 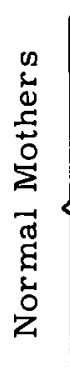 } & 12 & & & 0 & 6225 \\
\hline & 13 & 18 & $12^{*}$ & 0 & 12100 \\
\hline & 14 & 144 & $10^{\dagger}$ & 59 & 4810 \\
\hline & 14 & 144 & $10^{\dagger}$ & 50 & 3491 \\
\hline & 15 & 18 & $10^{*}$ & 178 & 15140 \\
\hline & .16 & 18 & $15 *$ & 0 & 523 \\
\hline & 16 & 48 & $10^{\dagger}$ & 0 & 658 \\
\hline \multirow{4}{*}{ 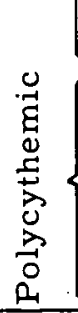 } & 19 & 12 & $12^{\dagger}$ & 20 & 530 \\
\hline & 15 & $\begin{array}{l}\text { Offspring born } \\
\text { dead }\end{array}$ & -- & $:-$ & 3968 \\
\hline & 19 & 24 & $3^{\dagger}$ & 6 & 4347 \\
\hline & 19 & 12 & $8^{\dagger}$ & 11 & 6119 \\
\hline
\end{tabular}

†offspring-all obtainable blood from offsprings counted in saline.

* Fetuses-not counted individually.

\section{RESULTS}

In these studies we were not interested in the effect of homologous transfusion-induced polycythemia on the capacity to conceive, or on the incidence of early or late abortion. Nevertheless; we did observe a high incidence of loss of fetus either by abortion or resorption. This was true whether blood was administered to the mother by the intravenous or intraperitoneal route. In general, it can be stated that of polycythemic animals brought to term, the size of litter, weight of the individual fetus and liver, and gestation time were comparable with those resulting from normal pregnancy (19-20 days). The variation that exists in the weight of individual fetuses and newborn from one litter to another (Table 2) appears to be influenced by the size of the litter and gestation time, which 
Table 2

REPRESENTATIVE HEMATOLOGIC VALUES AND WEIGHTS OF 3 LITTERS OF OFFSPRING FROM CF NO. 1 MICE WITHIN $1 / 2$ HOUR AFTER BIRTH

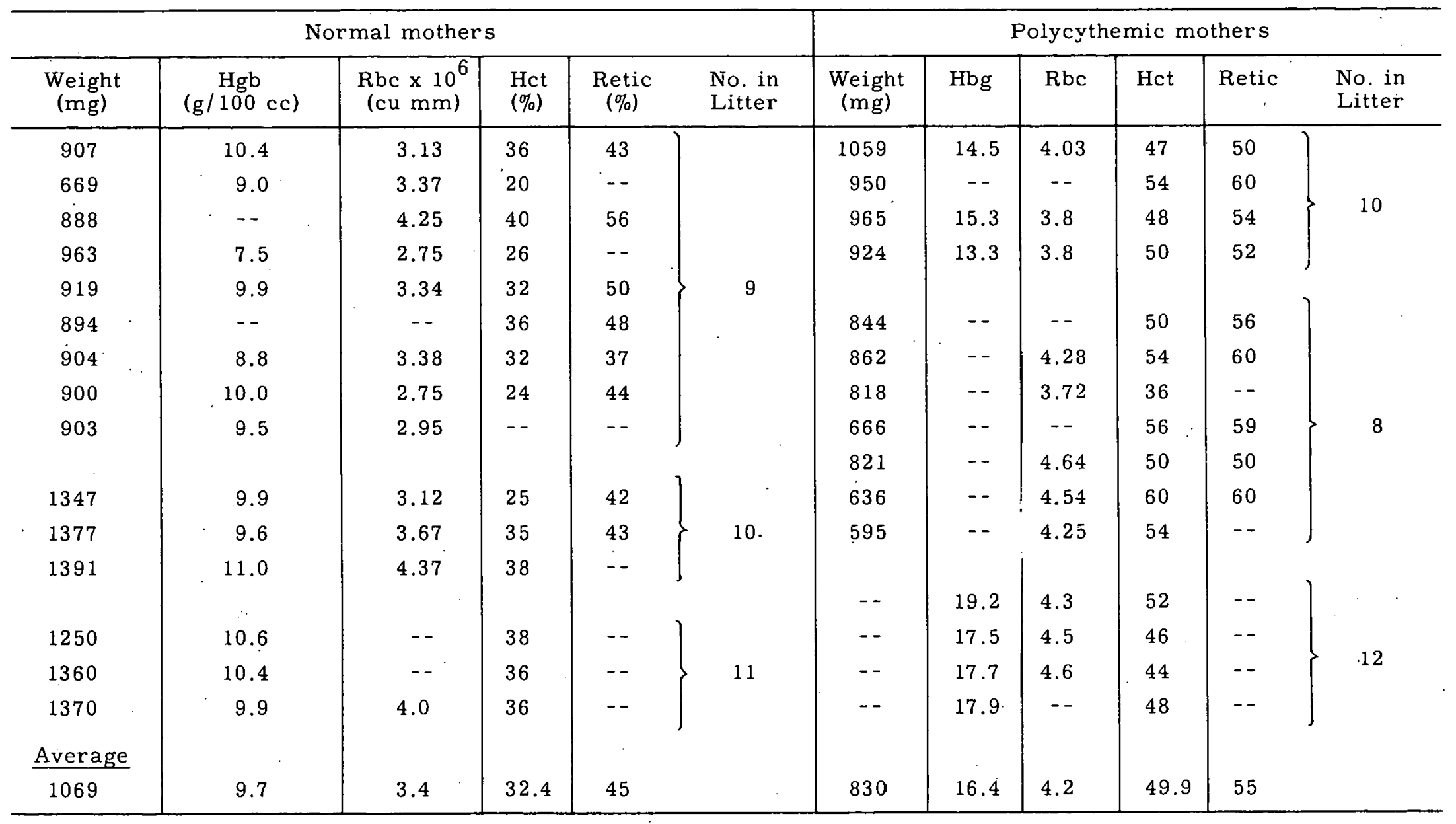


is in agreement with findings of other investigators, ${ }^{8,9}$ Table 3 gives the individual hematologic values for a normal mouse and its 18 -day-old fetuses. Table 4 gives similar data for a normal mouse and its newborn. Comparative hematologic values for polycythemic pregnant mice and their fetuses and newborn are shown in Tables 5 and 6.

The average hematologic values and weights of all the mice used in our experiments are shown in Tables 7 and 8.

The fetus or newborn of the polycythemic mother not only had higher hemoglobin, $\mathrm{RBC}$, and hematocrit values at birth than offspring from the "normal" non-polycythemic mother (Tables 2 and 7 ), but retained these higher levels for the period of observation ( 1 month). This indicates that the fetus of the polycythemic mother is able to initiate and maintain erythropoiesis and suggests that the higher hematologic values observed might be merely a result of supplying the fetus with iron by virtue of the multiple transfusions given to the mother. Thus, the fetuses of polycythemic mothers had adequate available iron, whereas the "normal" mouse had insufficient iron available for herself and young. We therefore gave iron-dextran (Imferon) parenterally to normal pregnant mice and found, as shown in Tables 9 and 10, that the newborn mice from iron-injected animals had hematologic values comparable with those of mice born of polycythemic mothers (Tables 7,9 , and 10 ).

Embryos removed from mothers, as well as mice born at full term, gave evidence that erythropoiesis is initiated at the same time and is qualitatively similar whether the mother is polycythemic or normal. Although minimal erythropoiesis can be found in the embryo in a number of sites, we confined our examination to the liver and the spleen.

By the 6 th day after transfusion-induced polycythemia has been established, clearly recognizable erythroblasts have disappeared from the bone marrow, spleen, and liver (the peripheral blood is reticulocyte-free at this stage also). This obtained even though mating had occurred and pregnancy was initiated. At intervals throughout gestation the mothers were sacrificed and the hematopoietic tissues examined as described above. At no stage were erythroblasts found with any degree of certainty. Reticulocyte values on the day of sacrifice in each instance were 0.0 per cent.

Erythropoiesis in the control mother with or without parenteral iron was qualitatively similar in the spleen and bone marrow at the various stages examined. As would be expected, the histologic material stained for iron and examined at term showed iron depletion in normal mothers. In the iron-dextran (Imferon)-injected mothers, stainable iron was visible, and in mothers with a transfusion-induced polycythemia, there was an extreme degree of iron deposition in the tissue.

The reticulocyte values for the fetus of a transfusion-induced polycythemic mother and the fetus of a normal mother were essentially comparable and varied only as shown in Table 2 .

Whole body $\mathrm{Fe}^{59}$ uptake for fetuses from polycythemic mothers was slightly higher on the average than that of fetuses from normal mothers (Table 11). The fetal $\mathrm{Fe}^{59}$ uptake increased with age and weight of the fetus. Bothwell and co-workers reported similar results 
Table 3

HEMATOLOGIC VALUES OF A NORMAL PREGNANT CF NO. 1 MOUSE AND ITS 18-DAY-OLD FETUSES

\begin{tabular}{|c|c|c|c|c|c|c|c|c|c|}
\hline \multirow{3}{*}{$\begin{array}{c}\text { Day of } \\
\text { gestation }\end{array}$} & \multirow{2}{*}{\multicolumn{6}{|c|}{ Mother }} & \multicolumn{3}{|c|}{ Fetuses } \\
\hline & & & & & & & \multicolumn{3}{|c|}{$\begin{array}{c}\text { Delivered by } \\
\text { cesarean section }\end{array}$} \\
\hline & $\begin{array}{c}\mathrm{Hbg} \\
\left(\mathrm{g} / 100^{\mathrm{cc}}\right)\end{array}$ & $\begin{array}{c}\mathrm{Rbc} \times 10^{6} \\
(\mathrm{cu} \mathrm{mm})\end{array}$ & $\begin{array}{l}\text { Hct } \\
(\%)\end{array}$ & $\underset{(\%)}{\text { Retic }}$ & $\begin{array}{c}\text { Wbc } \\
(\mathrm{cu} \mathrm{mm})\end{array}$ & $\begin{array}{l}\text { Weight } \\
\text { (g) }\end{array}$ & $\begin{array}{c}\text { Retic } \\
(\%)\end{array}$ & $\begin{array}{l}\text { Hct } \\
(\%)\end{array}$ & $\begin{array}{l}\text { Weight } \\
\text { (mg) }\end{array}$ \\
\hline 1 & 16.7 & 10.3 & 55 & 1.6 & 9150 & & 78 & 35 & 88 \\
\hline 8 & 16.4 & 9.3 & 48 & 5.2 & 11200 & & 82 & 28 & 74 \\
\hline 11 & 15.8 & 8.6 & 46 & 5.4 & 12950 & : & -- & 38 & 72 \\
\hline 13 & 13.5 & -- & 48 & 8.9 & 11400 & . & -- & -- & 66 \\
\hline 15 & 13.8 & 8.3 & 42 & 11.4 & 11200 & 33 & 80 & 24 & 70 \\
\hline 16 & $\cdot--$ & & & & & 34 & 77 & 20 & 83 \\
\hline 18 & 13.3 & 9.4 & 40 & 4.5 & 19500 & 35 & - & 28 & 70 \\
\hline & . & & & . & & & 85 & 30. & 69 \\
\hline & & & & & & & -- & 30 & 80 \\
\hline & & & & & & & -- & 28 & 73 \\
\hline
\end{tabular}


Table 4

HEMATOLOGIC VALUES AND WEIGHTS OF A NORMAL PREGNANT CF NO. 1 MOUSE AND 4 OF ITS OFFSPRING WITHIN 1 DAY AFTER BIRTH

\begin{tabular}{|c|c|c|c|c|c|c|c|c|c|c|c|c|}
\hline \multirow{3}{*}{$\begin{array}{c}\text { Day of } \\
\text { gestation }\end{array}$} & \multicolumn{6}{|c|}{ Mother } & \multicolumn{6}{|c|}{ Fetuses } \\
\hline & \multirow{2}{*}{$\begin{array}{c}\mathrm{Hbg} \\
(\mathrm{g} / 100 \mathrm{cc})\end{array}$} & \multirow{2}{*}{$\begin{array}{c}\text { Rbc } \times 10^{6} \\
(\mathrm{cu} \mathrm{mm})\end{array}$} & \multirow{2}{*}{$\begin{array}{l}\text { Hct } \\
(\%)\end{array}$} & \multirow{2}{*}{$\begin{array}{c}\text { Retic } \\
(\%)\end{array}$} & \multirow{2}{*}{$\begin{array}{c}\text { Wbc } \\
(\mathrm{cu} \mathrm{mm})\end{array}$} & \multirow{2}{*}{$\begin{array}{l}\text { Wt. } \\
(\mathrm{g})\end{array}$} & \multirow{2}{*}{$\mathrm{Hbg}$} & \multirow{2}{*}{$\mathrm{Rbc}$} & \multirow{2}{*}{ Hct } & \multirow{2}{*}{ Retics } & \multicolumn{2}{|c|}{ Weights (mg) } \\
\hline & & & & & & & & & & & Offspring & Liver \\
\hline 1 & 16.6 & 10.1 & 52 & 3.8 & 7500 & 29 & 12.5 & 3.2 & 44 & 44. & 1392 & 65 \\
\hline 4 & 15.0 & 10.3 & 48 & 7.9 & 13600 & -- & 10.0 & 3.85 & 44 & 33 & 1498 & 64 \\
\hline 7 & & & 42 & 7.4 & & 30.5 & 12.3 & 3.82 & 45 & 40 & 1500 & -- \\
\hline 9 & & & 39 & 8.0 & & 31 & & & & & & \\
\hline 11 & 11.7 & 6.87 & $40^{\circ}$ & 9.8 & 7600 & 33 & & & & & & \\
\hline 14 & & & 39 & 15.8 & & 38 & & & & & $\cdot$ & . \\
\hline 15 & 10.5 & 8.5 & 41 & 8.8 & & 40.5 & & & & & . & \\
\hline 18 & 11.0 & 6.5 & 36 & 4.0 & & 49.0 & & & & & . & \\
\hline 19 & & & 30 & 3.2 & & & & & & & & \\
\hline
\end{tabular}


Table 5

HEMATOLOGIC VALUES OF A PREGNANT POLYCYTHEMIC CF NO. 1 MOUSE AND ITS 18-DAY-OLD FETUSES

\begin{tabular}{|c|c|c|c|c|c|c|c|c|c|c|}
\hline \multirow{3}{*}{$\begin{array}{l}\text { Day of } \\
\text { gestation }\end{array}$} & \multirow{2}{*}{\multicolumn{7}{|c|}{ Mother }} & \multicolumn{3}{|c|}{ Fetuses } \\
\hline & & & & & & & & \multicolumn{3}{|c|}{$\begin{array}{c}\text { Delivered by } \\
\text { cesarean section }\end{array}$} \\
\hline & $\begin{array}{c}\mathrm{Hbg} \\
(\mathrm{g} / 100 \mathrm{cc})\end{array}$ & $\begin{array}{l}\mathrm{Rbc} \times 10^{6} \\
(\mathrm{cu} \mathrm{mm})\end{array}$ & $\begin{array}{l}\text { Hct } \\
(\%)\end{array}$ & $\underset{(\%)}{\text { Retic }}$ & $\begin{array}{c}\text { Wbc } \\
\text { (cu } \mathrm{mm})\end{array}$ & $\begin{array}{l}\text { Weight } \\
\text { (g) }\end{array}$ & $\begin{array}{l}\text { Rbc susp. } \\
\text { given }\end{array}$ & $\begin{array}{c}\text { Retics } \\
(\%)\end{array}$ & $\begin{array}{l}\text { Hct } \\
(\%)\end{array}$ & $\begin{array}{l}\text { Weight } \\
\text { (mg) }\end{array}$ \\
\hline 1 & 21.4 & 18.9 & 66 & 1.8 & 15900 & & IP & - & -- & 790 \\
\hline 4 & & & & & & & IP & 90 & 48 & 730 \\
\hline 6 & & & & & & & IP & -- & 40 & 790 \\
\hline 8 & 20.8 & 15.0 & 64 & 0.0 & 12400 & & IP & 80 & 54 & 820 \\
\hline 10 & & & & & & & IP & 70 & 49 & 830 \\
\hline 11 & 20.9 & 13.9 & 61 & 0.001 & 11700 & & IV & 75 & 40 & 830 \\
\hline 13 & 23 & 18.1 & 70 & 0.01 & 11100 & & IV & 86 & 46 & 810 \\
\hline 14 & & & 66 & 0.05 & & 36 & -- & 85 & 47 & 810 \\
\hline 15 & 24.6 & 16.5 & 76 & 0.2 & 31600 & & IV & 86 & 45 & 810 \\
\hline 16 & & & 66 & 0 & & 42 & -- & 90 & 36 & 680 \\
\hline 17 & & & 56 & 0 & & 45 & IV & 79 & 48 & 810 \\
\hline 18 & 21.1 & 13.1 & 62 & 0 & 36850 & 48 & & 78 & 52 & 850 \\
\hline & & & & & & & & 85. & 49 & 910 \\
\hline
\end{tabular}


Table 6

HEMATOLOGIC VALUES AND WEIGHTS OF A PREGNANT POLYCYTHEMIC CF NO. 1 NOUSE AND 4 OF ITS 9 OFFSPRING WITHIN 1 DAY AFTER BIRTH

\begin{tabular}{|c|c|c|c|c|c|c|c|c|c|c|c|c|c|}
\hline \multirow{3}{*}{$\begin{array}{l}\text { Day of: } \\
\text { gestation }\end{array}$} & \multicolumn{6}{|c|}{ Mother } &. & \multicolumn{6}{|c|}{ Fetuses } \\
\hline & \multirow{2}{*}{$\begin{array}{c}{ }^{\mathrm{Hbg}} \\
(\mathrm{g} / 100 \mathrm{cc})\end{array}$} & \multirow{2}{*}{$\begin{array}{c}\mathrm{Rbc} \times 10^{6} \\
(\mathrm{cu} \mathrm{mm})\end{array}$} & \multirow{2}{*}{$\begin{array}{l}\text { Het } \\
(\%)\end{array}$} & \multirow{2}{*}{$\begin{array}{c}\text { Retic } \\
(\%)\end{array}$} & \multirow{2}{*}{$\begin{array}{l}\because \mathrm{Wbc} \\
(\mathrm{cu} \mathrm{mm})\end{array}$} & \multirow{2}{*}{$\begin{array}{l}\text { Wt } \\
(\mathrm{g})\end{array}$} & \multirow{2}{*}{$\begin{array}{l}\text { Rbc given } \\
(0.5 \mathrm{cc})\end{array}$} & \multirow{2}{*}{$\begin{array}{c}\mathrm{Hgb} \\
(\mathrm{g} / 100 \mathrm{cc})\end{array}$} & \multirow{2}{*}{$\begin{array}{c}\mathrm{Rbc} \\
(\mathrm{cu} \mathrm{mm})\end{array}$} & \multirow{2}{*}{$\begin{array}{l}\text { Hct } \\
(\dot{\%})\end{array}$} & \multirow{2}{*}{$\underset{(\%)}{\text { Reti }}$} & \multicolumn{2}{|c|}{ Weights (mg) } \\
\hline & & & & & & & & & & & & Offspring & Liver \\
\hline$\therefore$ & 26 & 18.6 & 79 & 0.01 & 20000 & 24 & IP & 15.0 & -- & 40 & 43 & 1255 & 58 \\
\hline 3 & $:$ & & 78 & & & 24 & -- & 17.1 & -- & 52 & 28 & 1434 & 72 \\
\hline 4 & 24 & 15.9 & 76 & 0.0 & 12150 & -- & IP & 16.4 & 4.82 & 52 & 38 & 1410 & 56 \\
\hline 8 & .23 & 15.3 & 70 & 0.01 & 8400 & 25 & IP & & & & & & \\
\hline$\cdots:$ & $\cdot \cdot \cdot \cdot \cdot$ & $\cdots \cdots$ & .68 .5 & 0.0 & & & IP & - & $\because$ & $\cdots$ & .. & $:$ & \\
\hline 11 & 22 & $17.1 \therefore$ & 67 & 0.0 & . . & 27 & IP & $\ldots \ldots$ & .. & $\because$ & $\ldots$ & & \\
\hline 12 & & $\cdot$ & 68 & 0.01 & $:$ : & 28.5 & IP & & & & & & \\
\hline 14 & $\ldots \ldots$ & $\ldots$ & 67 & 0.0 & 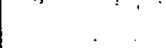 & 31 & $\div-$ & $\begin{array}{cc}\cdots & \cdots \\
\cdots & \cdots\end{array}$ & & & . & & \\
\hline 15 & -- & 17.8 & 69 & 0.0 & & 32 . & IV & $\cdot$ & & & & $\checkmark$ & \\
\hline 18 & 20.3 & 12.4 & 60 & 0.0 & & 40 & IV & & & & & & \\
\hline 19 & & & 63 & 0.0 & & & -- & & & & & & \\
\hline 21 & 26.0 & 14.1 & 65 & 0.0 & & & IV & & & & & & \\
\hline
\end{tabular}


Table 7

AVERAGE HEMATOLOGIC VALUES OF-FETUSES AND NEWBORN FROM NORMAL, IMFERON-INJECTED, AND .POLYCYTHEMIC MICE

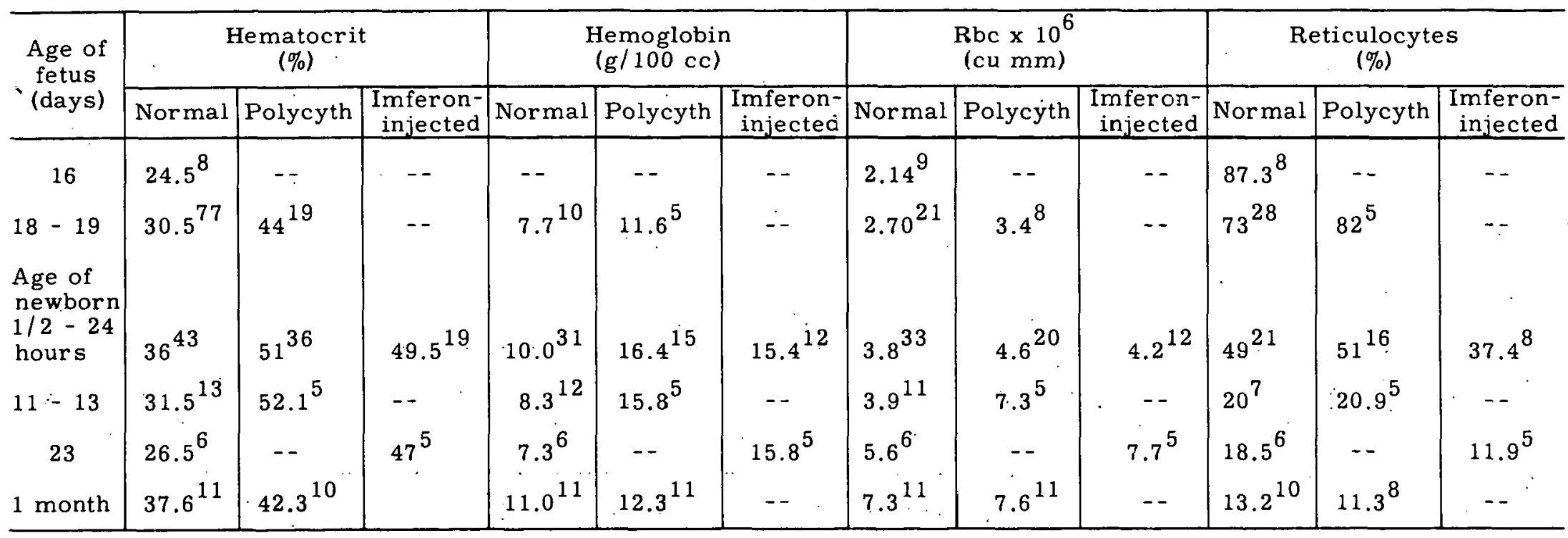

Superscript figures indicate number of specimens for each value given. 
Table 8

AVERAGE WEIGHTS OF FETUSES AND NEWBORN FROM NORMAL, IMFERON-INJECTED, AND POLYCYTHEMIC MICE

\begin{tabular}{|c|c|c|c|c|c|c|}
\hline \multirow{3}{*}{$\begin{array}{l}\text { Age of } \\
\text { fetus or } \\
\text { newborn } \\
\text { (days) }\end{array}$} & \multicolumn{6}{|c|}{ Weight } \\
\hline & \multicolumn{3}{|c|}{$\begin{array}{l}\text { Fetus or newborn } \\
(\mathrm{g})\end{array}$} & \multicolumn{3}{|c|}{$\begin{array}{l}\text { Liver } \\
\text { (mg) }\end{array}$} \\
\hline & Normal & Polycyth & $\begin{array}{l}\text { Imferon- } \\
\text { injected }\end{array}$ & Normal & Polycyth & $\begin{array}{l}\text { Imferon- } \\
\text { injected }\end{array}$ \\
\hline 16 & $0.541^{34}$ & $0.321^{28}$ & -- & $39.9^{22}$ & $34.1^{2}$ & -- \\
\hline $18-19$ & $0.903^{82}$ & $0.828^{24}$ & -- & $62.2^{31}$ & $56.5^{11}$ & -- \\
\hline $\begin{array}{c}\text { Age of } \\
\text { newborn } \\
1 / 2-24 \\
\text { hours }\end{array}$ & $1.223^{26}$ & $1.153^{26}$ & $1.47^{11}$ & $67.1^{25}$ & $68.3^{17}$ & $61.9^{12}$ \\
\hline $11-13$ & $5.4^{5}$ & $4.04^{5}$ & -- & -- & -- & -- \\
\hline 1 month & $12.7^{8}$ & $11.8^{11}$ & -- & $708^{12}$ & $703^{9}$ & -- \\
\hline
\end{tabular}

Superscript figures indicate number of specimens for each value given.

in the fetal iron uptake of rabbits. ${ }^{10}$ These results are considered possible evidence that erythropoiesis is greater in the fetus of the polycythemic mother than in that of the normal one. However, it seems unlikely that one can use data for $\mathrm{Fe}^{59}$ uptake in the offspring as a quantitative measure of erythropoiesis unless the litter sizes of control and polycythemic mothers were equal and the exact stages of fetal development were matched.

The $\mathrm{Cr}^{51}$-labeling data (Table 1) show, as expected, that the homologous red cells transfused into the mother do not pass through the placenta to the fetus in any detectable quantity.

\section{DISCUSSION}

Our data suggest that the embryo of the transfusion-induced polycythemic mouse has the capacity to initiate and maintain erythropoiesis, even though no erythropoietin(s) appears to be available from the maternal circulation. The validity of this suggestion rests upon the assumption that the reduction of erythropoiesis in transfusion-induced polycythemic mice and the sensitivity of these mice to "anemic" or "cobalt" plasma indicates that the circulating plasma erythropoietin(s) level is reduced drastically or absent.

Furthermore, our data indicate that little or no erythropoietin passes from the fetus to the mother. This is based on the fact that no reticulocytes appeared in the maternal circulation and there was no histologic evidence of erythropoiesis in the maternal tissues. If any appreciable amount were going from fetus to mother; one might expect some stimulation in the latter. It is conceivable that erythropoietin moves from the fetus to the mother but that the dilution factor in the maternal plasma is so great that it precludes a recognizable effect on erythropoiesis. 
Table 9

HEMATOLOGIC VAlues OF A NORMAL PREGNANT CF NO. 1. MOUSE THAT RECEIVED 0.25 cc (0.5 mg). OF IRON-DEXTRAN (IMFERON) INTRAMUSCULARLY AND OF ITS OFFSPRING (๕) WITHIN 1 DAY AFTER BIRTH

\begin{tabular}{|c|c|c|c|c|c|c|c|c|c|c|c|c|c|}
\hline \multirow{3}{*}{$\begin{array}{l}\text { Day of } \\
\text { gestation }\end{array}$} & \multicolumn{7}{|c|}{ Mother } & \multicolumn{6}{|c|}{ Fetuses } \\
\hline & \multirow{2}{*}{$\begin{array}{c}\mathrm{Hbg} \\
(\mathrm{g} / 100 \mathrm{cc}) \\
\end{array}$} & \multirow{2}{*}{$\begin{array}{c}\mathrm{Rbc} \times 10^{6} \\
(\mathrm{cu} \mathrm{mm})\end{array}$} & \multirow{2}{*}{$\begin{array}{l}\cdot \text { Hct } \\
(\%)\end{array}$} & \multirow{2}{*}{$\begin{array}{c}\text { Retic } \\
(\%)\end{array}$} & \multirow{2}{*}{$\begin{array}{c}\text { Wbc } \\
\text { (cu mm) }\end{array}$} & \multirow{2}{*}{$\begin{array}{l}W t \\
(g)\end{array}$} & \multirow{2}{*}{$\begin{array}{l}\text { Days } \\
\text { Imferon } \\
\text { given }\end{array}$} & \multirow{2}{*}{$\begin{array}{c}\mathrm{Hbg} \\
\left(\mathrm{g} / 100^{\mathrm{cc}}\right)\end{array}$} & \multirow[t]{2}{*}{$R b c$} & \multirow[t]{2}{*}{ Het } & \multirow[t]{2}{*}{ Retic } & \multicolumn{2}{|c|}{ Weights (mg) } \\
\hline & & & & & & & & & & & & Offspring: & Liver \\
\hline 1 & 17.7 & 10.5 & 58 & 5.0 & & & $"$ & 15.8 & 3.60 & 44 & 33.5 & 1424.5 & 58 \\
\hline 2 & & & & & & & & 15.8 & 5.07 & 50 & 36.4 & 1542 & 65 \\
\hline 3 & 15.6 & 11.1 & 47 & 4.8 & 12350 & & $"$ & 16.3 & 4.02 & 50 & 3.8 & 1510 & 71 \\
\hline 6 & & . & 44 & 8.8 & . & & $" 1$ & 12.9 & 3.85 & 40 & 38.4 & 1583.5 & 62.5 \\
\hline 7 & 14.2 & 9.7 & 49 & 11.2 & $12300^{\circ}$ & & -- & 15.2 & 4.12 & 48 & . 28.4 & $\therefore \quad--$ & 59 \\
\hline 8 & & $\cdot$ & 44 & 14.1 & & & $"$ & 15.3 & 4.82 & 48 & $: \quad 46$ & $\therefore 1405$ & 66 \\
\hline 9 & & & & & & & $"$ & 16.3 & 3.92 & 48 & 34.6 & .1407 & 51 \\
\hline 10 & 12.3 & 9.9 & 42 & $9.0^{\circ}$ & 13600 & & $"$ & . $\quad 16.3$ & 3.72 & 52 & $4 \ddot{4} .1$ & 1458 & 64 \\
\hline 13 & & & 43 & 11.2 & - & & $"$ & & & & & & : \\
\hline 14 & 12.7 & 9.4 & 49 & 16.0 & $\ldots$ & 32 & $"$ & & & & & : & \\
\hline 16 & & & & & & 32 & & & & & $\vdots$ & . & \\
\hline 17 & 14.6 & 7.7 & 48 & 12.4 & & 38 & $"$ & $\therefore$ & & & . & & : \\
\hline 20 & 13.5 & 6.8 & 50 & 4.4 & & & . & . & & & . & 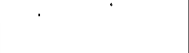 & $\therefore$ \\
\hline 21 & 13.8 & 6.02 & 42 & 3.4 & & 31. & . & & & & & & \\
\hline
\end{tabular}


Table 10

HEMATOLOGIC VALUES OF A NORMAL PREGNANT CF NO. 1 MOUSE THAT RECEIVED 0.25 CC $(0.5 \mathrm{mg})$ OF IRON-DEXTRAN (IMFERON) INTRAMUSCULARLY AND OF ITS

OFFSPRING (11) WITHIN 1. DAY AFTER BIRTH

\begin{tabular}{|c|c|c|c|c|c|c|c|c|c|c|c|c|c|}
\hline \multirow{3}{*}{$\begin{array}{c}\text { Day of } \\
\text { gestation }\end{array}$} & \multicolumn{7}{|c|}{ Mother } & \multicolumn{6}{|c|}{ Fetuses } \\
\hline & \multirow{2}{*}{$\begin{array}{c}\mathrm{Hbg} \\
(\mathrm{g} / 100: \mathrm{cc})\end{array}$} & \multirow{2}{*}{$\begin{array}{c}\mathrm{Rbc} \times 10^{6} \\
(\mathrm{cu} \mathrm{mm})\end{array}$} & \multirow{2}{*}{$\begin{array}{l}\mathrm{Htc} \\
(\%)\end{array}$} & \multirow{2}{*}{$\begin{array}{c}\text { Retic } \\
(\%)\end{array}$} & \multirow{2}{*}{$\begin{array}{c}\text { Wbc } \\
(\mathrm{cu} \mathrm{mm})\end{array}$} & \multirow{2}{*}{$\begin{array}{l}W t \\
(g)\end{array}$} & \multirow{2}{*}{$\begin{array}{l}\text { Days } \\
\text { Imferon } \\
\text { given }\end{array}$} & \multirow{2}{*}{$\begin{array}{c}\mathrm{Hbg} \\
\left(\mathrm{g} / 100_{\mathrm{cc}}\right)\end{array}$} & \multirow{2}{*}{$\mathrm{Rbc}$} & \multirow{2}{*}{ Hct } & \multirow{2}{*}{ Retic } & \multicolumn{2}{|c|}{ Weights (mg) } \\
\hline & & & & & & & & & & & & Offspring & Liver \\
\hline 1 & 16.4 & & 56 & 4.0 & & & 11 & 13.8 & 5.25 & 57 & 67 & 1490 & 61 \\
\hline 2 & & & & & & & 11 & 15.0 & 3.62 & 50 & 61 & 1432 & 55.5 \\
\hline 3 & 16.6 & 12.4 & 52 & 6.2 & 16200 & & $"$ & 16.3 & 4.62 & 52 & -- & 1510 & 65 \\
\hline 7 & 14.6 & 9.6 & 51 & 7.2 & 10250 & & -- & . & & & & & \\
\hline 8 & & & 42 & 6.2 & & & $" 1$ & & & & & & \\
\hline 9 & $\cdots$ & $\cdot$ & & & & & $"$ & & & & & & \\
\hline 10 & 14.2 & 10.0 & 48 & 14.4 & 5500 & & $" 1$ & & . & & & & \\
\hline 13 & & $\therefore$ & 46 & 19.0 & & & 11 & & & & & & \\
\hline 14 & 13.8 & 9.2 & 44 & 19.0 & & 37 & $" 1$ & & & & & . & \\
\hline 17 & 14.6 & 8.6 & 47 & 20.8 & & 45 & $" 1$ & & & & & & \\
\hline 20 & 13.8 & 8.7 & 48 & 4.6 & & & - - & & & & & & \\
\hline 21 & 13.5 & 9.6 & 50 & -- & & & & & & & & & \\
\hline
\end{tabular}


Table 11

- RADIOACTIVITY OF NORMAL AND POLYCYTHEMIC MOTHERS AND THEIR FETUSES 18 HOURS AFTER THE INTRAVENOUS INJECTION OF $\mathrm{Fe}^{59}$

\begin{tabular}{|c|c|c|c|c|c|c|c|c|}
\hline \multirow{3}{*}{$\begin{array}{c}\mathrm{Fe}^{59} \text { injected } \\
\text { days of } \\
\text { gestation }\end{array}$} & \multicolumn{4}{|c|}{ Normal mouse } & \multicolumn{4}{|c|}{ Polycythemic mouse } \\
\hline & \multirow{2}{*}{$\begin{array}{l}\text { No. of } \\
\text { fetuses } \\
\text { per mouse } \\
\end{array}$} & \multicolumn{2}{|c|}{$\begin{array}{c}\text { Radioactivity } \\
(\mathrm{cpm})\end{array}$} & \multirow{2}{*}{$\begin{array}{l}\% \text { Iron } \\
\text { uptake in } \\
\text { fetuses. }\end{array}$} & \multirow{2}{*}{$\begin{array}{c}\text { No. of } \\
\text { fetuses } \\
\text { per mouse }\end{array}$} & \multicolumn{2}{|c|}{$\begin{array}{c}\text { Radioactivity } \\
(\mathrm{cpm})\end{array}$} & \multirow{2}{*}{$\begin{array}{l}\text { \% Iron } \\
\text { uptake in } \\
\text { fetuses }\end{array}$} \\
\hline & & Mother & Fetus & & & Morher & Fetus & \\
\hline \multirow[t]{2}{*}{15} & 10 & 45770 & 10066 & 21.9 & 14 & 45177 & 12423 & 27.4 \\
\hline & 13 & 46216 & 9963 & 21.5 & & & & \\
\hline $17-18$ & 13 & 42470 & 18720 & 44 & 11 & 33600 & 14927 & 44.4 \\
\hline $18-19$ & 10 & 55600 & 25801 & 46.4 & 13 & 59805 & 31504 & 52.6 \\
\hline . & 8 & 59323 & 25660 . & 43 & & & & \\
\hline
\end{tabular}


If one assumes that the embryo has the capacity to initiate and maintain erythropoiesis completely, then it is interesting to speculate farther as to the site of production. If our previous suggestion that the kidney is related to erythropoietin production is correct, ${ }^{11}$ then the embryo must be able to derive it from an "anlage," since erythropoiesis begins in the embryo before the kidney is established as a functional unit in the ordinary sense. Perhaps fetal erythropoiesis is initiated and maintained by a mechanism unlike that which regulates erythropoiesis in the adult. A way to study this might be to transfuse the embryo in vivo to learn whether the transfusions would reduce erythropoiesis as completely as they do in the adult mouse. We are also interested in the effect of the injection of exogenous erythropoietin on fetal erythropoiesis; in fact, this may be a way of determining whether a transfer to the mother is possible.

It was interesting, but not too surprising, to find that the young laboratory mouse gives birth to an anemic infant and that this can be remedied by the administration of iron or red cell transfusion to the mother.

\section{SUMMARY AND CONCLUSIONS}

Erythropoiesis is reduced to zero in the mouse by repeated homologous red cell transfusion.

Mating of transfusion-induced polycythemic mice was allowed and observations were made on maternal and fetal erythropoiesis.

It was observed that erythropoiesis in the pregnant, polycythemic mouse was suppressed throughout pregnancy, suggesting that erythropoietin production was concomitantly suppressed.

Erythropoiesis in the fetuses of polycythemic mothers was initiated by 12 days and maintained in an active state throughout fetal life. Hematologic values of these fetuses at birth were higher than those of the newborn normal pregnant mice of the same strain.

It is possible that the fetus initiates and maintains erythropoietin independently of erythropoietin from the maternal circulation. The higher hematologic values of the newborn of polycythemic mothers are probably the result of the greater availability of iron from the breakdown of transfused cells since it was found that comparable hematologic values were achieved in the newborn when iron-dextran(Imferon) was injected into the maternal tissues during pregnancy.

\section{LITERATURE CITED}

1. Jacobson, L. O., E. Goldwasser, L. Plzak, and W. Fried. Proc. Soc. Exp. Biol. Med., $94: 243,1957$.

2. Goldwasser, E., L. O. Jacobson, W. Fried, and L. Plzak. Blood, 13:55, 1958.

3. Contopoulos, A. N., D. C. Van Dyke, and M. E. Simpson. Proc. Soc. Exp. Biol. Med., $93: 424,1956$.

4. Döring, G. K. Arch. f. d. ges. Physiol., 249:631, 1948. 
5. Loeschcke, H. H. Fermentforsch., 3:346, 1949-50.

6. Beutler, E., W. Drennan, and M. Block. J. Lab. Clin. Med., 43:427, 1954.

7. Krantz, S., E. Goldwasser, and L. O. Jacobson. Submitted for publication in Blood.

8. Enzmann, E. V. Anat. Record., 62:31, 1935.

9. Allen, E., and E. L. MacDowell. Anat. Record., 77:165, 1940.

10. Bothwell, R. H., W. F. Pribilla, W. Mebust, and C. A. Finch. Amer. J. Physiol., 193: $615,1958$.

11. Jacobson, L. O., E. Goldwasser, W. Fried, and L. Plzak. Nature, 179:633, 1957. 


\section{STUDIES ON ERYTHROPOIESIS. XIII. A COMPARISON OF METHODS OF BIOASSAY OF ERYTHROPOIETIN IN HUMAN PLASMA*}

By

C. W. Gurney and C. Pan

Since Carnot and Deflandre's description of the erythropoietic-stimulating quality of anemic serum, ${ }^{1}$ there have been many attempts, reviewed by Grant and Root, ${ }^{2}$ to demonstrate this property in plasma of animals and man. However, results often were equivocal or negative. A noteworthy contribution was made when incorporation of $\mathrm{Fe}^{59}$ by red cells, originally described by Huff et al., ${ }^{3}$ was adapted for bioassay of erythropoietin, the erythropoietic-stimulating factor in anemic plasma. ${ }^{4}$ Modifications of this procedure have been employed to demonstrate erythropoietin in plasma of normal subjects ${ }^{5}$ and patients with a variety of hematological disorders. ${ }^{5,6}$ In previous publications, ${ }^{5,7}$ we have commented on the limitations of assay methods currently used and the loss of erythropoietin in fractionation of plasma prior to assay. Ways have been sought to circumvent these losses and to increase the sensitivity of the bioassay. The purposes of this publication are 1) to report the assay of unfractionated plasma, thereby obviating erythropoietin losses by extraction, and 2) to present a comparison of the two assay animals we have employed to demonstrate erythropoietin in human plasma.

\section{MATERIAL AND METHODS}

Blood was collected from normal volunteers and anemic patients, using heparin as an anticoagulant. After centrifugation in the cold, the plasma was removed and stored in the frozen state until ready for assay or fractionation. Frozen plasma was thawed at room temperature, and whole plasma or a heat-denatured extract prepared by the method of Bor sook and co-workers ${ }^{8}$ was used for assay. The plasma was acidified to $\mathrm{pH} 5.5$ by the addition of $.1 \mathrm{~N} \mathrm{HCl}$ and heated in a boiling water bath for ten minutes. The suspension was filtered through analytical filter paper (No. 595), and the precipitate resuspended in distilled water in a volume equal to the original plasma volume, heated an additional ten minutes, filtered, again resuspended, heated, and filtered. The filtrates were combined and reduced to original volume in a rotary flash evaporator, and the $\mathrm{pH}$ was adjusted to 7.4 by the addition of .1 $\mathrm{N} \mathrm{NaOH}$. This extract was then frozen until ready for assay.

Male rats of the Sprague-Dawley strain were used, five in each assay. The procedure of Fried et al. ${ }^{9,10}$ was followed. Young normal rats, weighing 100 to $120 \mathrm{~g}$, were starved 32 hours prior to the first injection of material being assayed and maintained in the starved state throughout the duration of the bioassay, water being permitted ad libitum.

\footnotetext{
${ }^{*}$ Text of a paper that has been submitted for publication in Blood.
} 
Six-week-old animals were hypophysectomized by the Hormone Assay Laboratories of Chicago, and one to two weeks later were used for assay. Two $\mathrm{ml}$ of plasma extract were injected subcutaneously daily for two days. On the third day, under light ether anesthesia, a tracer dose of $1 \mu \mathrm{c}$ of $\mathrm{Fe}^{59}$ citrate was given intravenously, and standards were prepared for later counting. Sixteen hours later, $1 \mathrm{ml}$ of blood was obtained by cardiac aspiration, and the $\mathrm{Fe}^{59}$ incorporation into red cells was calculated according to the following for-mula:

$$
\mathrm{Fe}^{59} \text { uptake }=\frac{\text { net counts per } \mathrm{ml} \text { blood } \mathrm{x} .05 \text { body weight }}{\text { net counts injected }}
$$

In these experiments, the blood volume was assumed to be $5 \%$ of the body weight. ${ }^{10}$

\section{RESULTS}

Normal values. Plasma and heat-denatured extract of plasma from 12 normal donors (all hemoglobins were between 14 and $17 \mathrm{~g}$ for males, 13 to $16 \mathrm{~g}$ for females) were assayed in both starved and hypophysectomized rats. The average results, plus or minus one standard deviation, are recorded in Figure 1. In subsequent analyses of anemic plasma, results exceeding these averages by more than two standard deviations of the latter were considered positive.

STARVED RAT

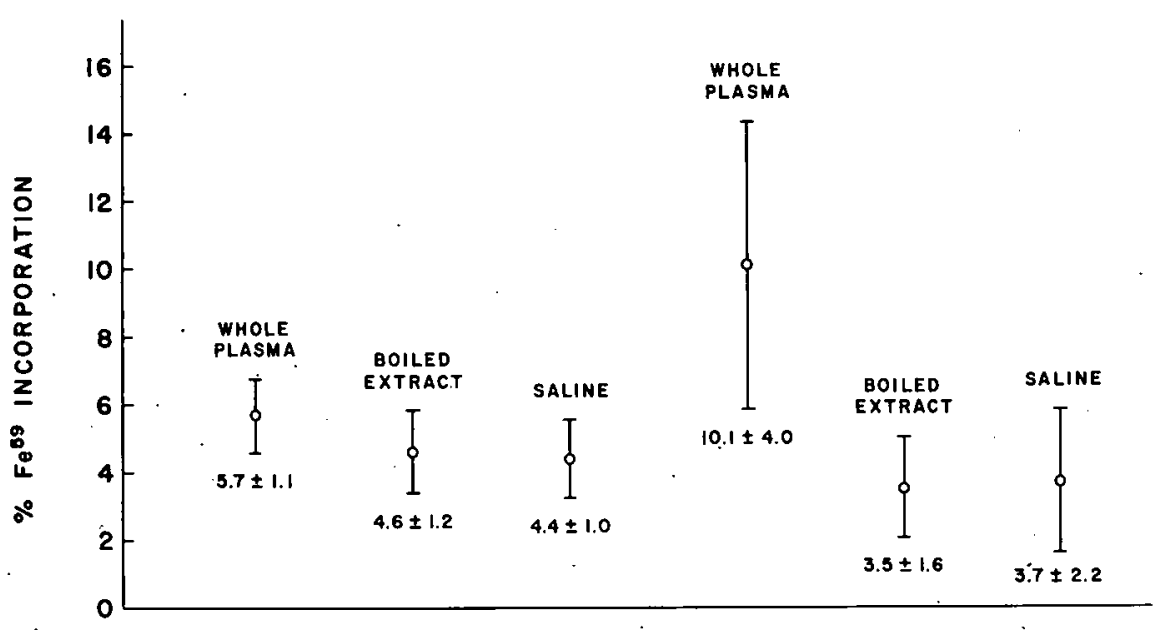

Figure 1. Bioassay, of erythropoietin in human plasma control values from 12 normal donors expressed as average \pm standard deviation.

Assay of anemic plasmas. Nineteen plasma specimens obtained from patients with hemoglobins under $8.5 \mathrm{~g}$ per cent, were assayed before and after protein removal by heatdenaturation in both starved and hypophysectomized rats. Diagnoses, hemoglobin levels, and the results, expressed as the average of five animals in each assay, are recorded in 
Table 1. It will be noted that the most-sensitive assay procedure involves the testing of whole plasma in starved rats, in which instance twelve of nineteen specimens were positive. In only one instance was a plasma negative by assay in the starved rat and positive in the hypophysectomized rat.

Table 1

COMPARISON OF ERYTHROPOIETIN BIOASSAY PROCEDURES

\begin{tabular}{|c|c|c|c|c|c|}
\hline \multirow[b]{2}{*}{ Diagnosis } & \multirow[b]{2}{*}{$\mathrm{Hb}$} & \multicolumn{2}{|c|}{ Starved rat. } & \multicolumn{2}{|c|}{ Hypophysectomized rat } \\
\hline & & Whole plasma & Boiled extract & Whole plasma & Boiled extract \\
\hline Normal & & $5.7 \pm 1.1 \%$ & $4.6 \pm 1.2 \%$ & $10.1 \pm 4.0 \%$ & $3.5 \pm 1.6 \%$ \\
\hline Myeloma & 3.6 & $26.6+$ & $18.5+$ & $29.8+$ & $11.6+$ \\
\hline Aplastic anemia & 8.1 & $15.5+$ & $9.8+$ & $25.1+$ & $12.1+$ \\
\hline Hodgkins disease & 3.5 & $27.6+$ & $4.8-$ & $27.1+$ & $1.9-$ \\
\hline Leukemia & 5.0 & $28.8+$ & $4.7-$ & $27.3+$ & $3.2-$ \\
\hline Aplastic anemia & 5.5 & $33.0+$ & 7. $1+$ & $28.9+$ & $4.3-$ \\
\hline Myoglobinuria & 7.2 & $12.0+$ & $7.8+$ & $21.8+$ & $3.4-$ \\
\hline Pernicious anemia & 3.5 & $8.5+$ & $7.7+$ & $22.8+$ & $6.1-$ \\
\hline Leukemia & 6.0 & $20.4+$ & $9.0+$ & $30.3+$ & $2.3-$ \\
\hline $\begin{array}{l}\text { Acute GI. hemorrhage } \\
\text { chronic pyelonephritis }\end{array}$ & 4.7 & $8.7+$ & $7.8+$ & $7.0-$ & $3.8-$ \\
\hline Carcinomatosis-breast & 7.7 & $17.5+$ & $8.5+$ & $9.3-$ & $3.8-$ \\
\hline Lymphosarcoma & 7.9 & 9.0 & $5.9-$ & $13.6-$ & $2.6-$ \\
\hline Leukemia & 3.1 & $30.6+$ & $5.4-$ & $31: 7+$ & $8.6+$ \\
\hline Leukemia & 6.6 & $6.3-$ & $5.4-$ & $18.2+$ & $5.3-$ \\
\hline Lymphosarcoma & 8.0 & $6.4-$ & $4.8-$ & $14.3-$ & $2.6-$ \\
\hline Myeloid meta. & 4.8 & $4.2-$ & $5.6-$ & $5.3-$ & $2.6-$ \\
\hline Myeloid meta. & 6.8 & $7.6-$ & $5.8-$ & $6.6-$ & $5.6-$ \\
\hline Myeloid meta. & 6.1 & $7.5-$ & $4.0-$ & $10.5-$ & $3.0-$ \\
\hline Leukemia & 6.9 & $5.6-$ & $3.5-$ & $8.1-$ & $1.3-$ \\
\hline Myeloma. & 7.3 & $4.0-$ & $5.0-$ & $2.8-$ & $2.4-$ \\
\hline SUMMARY $\frac{\text { Positive }}{\text { Total }}$ & & $\frac{12}{19}$ & $\frac{8}{19}$ & $\frac{10}{19}$ & $\frac{3}{19}$ \\
\hline
\end{tabular}

\section{DISCUSSION}

Since Bor sook and co-workers showed erythropoietic activity of the boiled extract of anemic rabbit plasma by demonstrating its stimulating effect in rats, ${ }^{8}$ it has been cus:tomary for investigators to extract plasma in this manner prior to bioassay. $5,6,11,12$ Indeed, even urine from anemic donors was treated in this fashion ${ }^{13}$ prior to injection into rats in an effort to demonstrate the existence of urinary erythropoietin. We have previ- 
ously reported finding erythropoietic-stimulating properties in the heat-denatured extract of human plasma obtained from many, but not all anemic donors. ${ }^{5}$ Although no known change in the assay procedures or in the hypophysectomized animals was introduced, a number of negative assays subsequently obtained were difficult to interpret if current concepts of the significance of erythropoietin are correct. ${ }^{7,14}$ This investigation was, therefore, designed to measure the degree to which we were losing activity when plasma was fractionated by heat-denaturation. It also appeared worthwhile to compare the response of the acutely slarved rat, ${ }^{10}$ a less expensive and more resistant animal, with that of the hypophysectomized rat, the animal we employed initially to demonstrate erythropoietin in human plasma. ${ }^{5}$

In all instances where whole plasma was found to be positive, a reduction in activity was noted after most of the protein was removed by heat-denaturation. This observalion is applicable to both starved and hypophysectomized rats. In some instances, the loss of active material was so great that the heat-denatured extract was negative. This observation is in accord with the findings of Linman et al. ${ }^{15}$ These investigators present evidence for the existence of two erythropoietins, one of which is "relatively thermolabile" and augments iron incorporation and hemoglobin synthesis. We have also experienced some loss of activity when plasma proteins were removed by precipitation with ethanol in the cold or with perchloric acid. The possibility exists that the method of fractionation, employing ammonium sulphate, recently reported by Lowy, Keighley, and Borsook to yield a fraction, which, on a protein basis, is 5 to 10 times more potent than the filtrale of the boiled ancmic plasma, ${ }^{16}$.may permit a more quantitative recovery of erythropoietin.

Rats tolerated two injections of the unfractionated human plasma without any demonstrable ill effects. Perhaps this is related to the difficulty with which rats form antibodies to soluble antigen. 17

In this series of nineteen plasmas tested, it would appear that the most sensitive method employs the starved rat to assay whole unfractionated plasma. This is fortunate, because this preparation is more easily maintained and less expensive than the hypophysectomized $r$ at. It is surprising and fortunate that the nutritional value of $4 \mathrm{ml}$ of human plas$\mathrm{ma}$ is not enough to reverse the depression of erythropoiesis in the starved rats as meas ured by $\mathrm{Fe}^{59}$ incorporation into the peripheral red cells.

Although a considerable degree of stimulation of iron incorporation into erythrocytes is obtained following injection of whole anemic plasma in the hypophysectomized rat as compared with iron incorporation following injection of saline, these results must be evaluated in relation to a higher and more variable result obtained with normal plasma. The difference between test values and the average normal value is therefore less striking than for the starved rat.

The stimulatory effect of whole human plasma on erythropoiesis in the hypophysectomized rat is difficult to interpret. In light of the results obtained on assay of plasma from anemic patients, it appears unlikely that the hypophysectomized rat is more sensitive than the starved rat. Therefore, it appears unlikely that the average difference between saline $(3.7 \%)$ and whole human plasma from normal donors $(10.1 \%)$ in the hypophysectomized rat 
is a measure of erythropoietin in normal plasma, and other explanations must be sought. Perhaps whole human plasma supplies a sufficient quantity of one or more hormones, a deficiency of which in the hypophysectomized rat is thought to be the basis for the depression of erythropoiesis in this assay animal, ${ }^{10}$ that induce this increased erythropoiesis. This possibility is worthy of serious consideration and warrants further investigation, because, if true, it casts serious doubt upon the validity of assaying human plasma or even plasma extracts from anemic patients in the hypophysectomized rat unless by prior fractionation substances other than erythropoietin, which might be capable of stimulating erythropoiesis indirectly in the hypophysectomized rat, are first removed.

The least sensitive assay procedure involved testing the heat-denatured extract of whole plasma in the hypophysectomized rat. This was a surprising finding because in an earlier study, ${ }^{5}$ we found ten of eighteen specimens positive in the hypophysectomized rat. No change in the assay procedure was instituted, and insofar as can be determined, the animals used in this study were bred, maintained, and supplied in the same fashion as those employed previously. However, variability in assay animals has been commented on by other investigators ${ }^{18}$ and may also be responsible for the apparent decrease of sensitivity noted here. That the difference may at least in part be attributed to the different patients donating plasma for this may be ascertained from the results of two additional assays not included in Table 1 because enough plasma was not available for all four assays. One was an assay of plasma from a patient with hypoplastic anemia reported positive in a previous publication. ${ }^{5}$ This plasma was stored in a deep freeze at $-20^{\circ} \mathrm{C}$ for four months. Enough was available for assay of whole plasma and the heat-denatured extract in only one animal preparation and, therefore, the hypophysectomized rat was used. The results were $51.2 \pm 4.2 \%$ for whole plasma and $34.6 \pm 4.1 \%$ for the heat-denatured extract. Twenty $\mathrm{ml}$ of plasma obtained from a child with congenital hypoplastic anemia was made available to us by Dr. Mila Pierce, Professor, Department of Pediatrics, The University of Chicago. The heat-denatured extract of this material was found to be positive, an average $13.3 \pm 5.2 \%$ being obtained when tested in the hypophysectomized rat. It is interesting that a boiled extract of plasma obtained from a patient with this disease was first reported negative for erythropoietin by Piliero et al. ${ }^{13}$ and it was suggested that erythropoietin deficiency might be implicated in the pathogenesis of this disease. In a later publication, ${ }^{18}$ however, these authors demonstrated erythropoietin in the patient's plasma. Perhaps loss of activity during fractionation of the initial plasma specimen contributed to the negative results.

The significance of negative assays, discussed in detail in a previous publication, ${ }^{5}$ continues to remain obscure. It is of interest that plasma from two of the patients with myeloid metaplasia was also found to be nonpositive when tested by means of a micro-bioassay procedure recently developed in our laboratory. 19,20 The role of erythropoietin deficiency in the pathogenesis of anemia cannot be adequately assessed until more quantitative and sensitive assay methods are perfected or erythropoietin is available for clinical testing. 


\section{SUMMARY AND CONCLUSIONS}

1. The plasma and heat-denatured extract of plasma from nineteen anemic patients were assayed for erythropoietic-stimulating properties in hypophysectomized and starved rats of the Sprague-Dawley strain. The results were compared to normal values established by testing normal plasma and a heat-denatured extract of it, obtained from twelve donors.

2. The most sensitive procedure in this study was the assay of whole plasma in the starved rat, where twelve of the nineteen specimens were positive.

3. Appreciable losses of activity result when plasma proteins are removed by heatdenaturation.

\section{LITERATURE CITED}

1. Carnot, P., and C. Deflandre. Compt. rend. Acad. sc., 143:384, 1906.

2. Grant, W. C., and W. S. Root. Physiol. Reviews, 32:449, 1952.

3. Hahn, P.F., W. F. Bale, E. O. Lawrence, and G. H. Whipple. J. Exper. Med., 69:739, 1939.

4. Plzak, L. F., W. Fried, L. O. Jacobson, and W. F. Bethard. J. Lab. Clin. Med., 46: $671,1955$.

5. Gurney, C. W., E. Goldwasser, and C. Fan. J. Lab. Clin. Med., 50:534, 1957.

6. Prentice, T. C., and E. A. Mirand. Blood, 12:993, 1957.

7. Gurney, C. W., L. O. Jacobson, and E. Goldwasser. Annals of Internal Medicine (in press).

8. Bor sook, H., A. Graybiel, G. Keighley, and E. Windsor. Blood, 9:734, 1954.

9. Fried, W., L. F. Plzak, L. O. Jacobson, and E. Goldwasser. Proc. Soc. Exp. Biol. Med., $92: 203,1956$.

10. Fried, W., L. F. Plzak, L. O. Jacobson, and E. Goldwasser. Proc. Soc. Exp. Biol. Med., 94:237, 1957.

11. Gordon, A. S., S. J. Piliero, and M. Tannenbaum. Am. J. Physiol., 181:585, 1955.

12. Linman, J. W., and F. H. Bethell. Blood, 11:310, 1956.

13. Piliero, S. J., P. T. Medici, B. Pansky, A. L. Luhby, and A. S. Gordon. Proc. Soc. Exp. Biol: Med., 93:302, 1956.

14.. Jacobson, L. O., and E. Goldwasser. Brookhaven Symposia in Biology, 10:110, 1958.

15. Linman, J. W., F. H. Bethell, and M. J. Long. J. Lab. Clin. Med., 51:8, 1958.

16. Lowy, P. H., G. Keighley, and H. Bor sook. Nature, 181:1802, 1958.

17. Kenton, H. B. J. Infectious Dis., 69:238, 1941.

18. Medici, P: T., A. S. Gordon, S. J. Piliero, A. L. Luhby; and P. Yucleoglu: Acta.. haemat., $18: 325,1957$. 
19. Schroeder, L., C. W. Gurney, and N. Wackman. Nature, 181:1537, 1958.

20. Gurney, S. W., and L. Schroeder: Unpublished data. 


\section{STUDIES ON ERYTHROPOIESIS: XIV. THE RELATIONSHIP OF HUMORAL STIMULATION TO IRON ABSORPTION* \\ By}

S. Krantz, E. Goldwasser, and L. O. Jacobson .

\section{INTRODUCTION}

It has long been evident that some mechanism exists in the mammal that regulates the absorption of dietary iron. ${ }^{1-4}$ When animals are made anemic by phlebotomy, ${ }^{5,6}$ or by hemolysis with acetyl phenylhydrazine, ${ }^{7,8}$ the absorption of iron is increased. These methods of causing anemia also result in increased formation of erythropoietin, ${ }^{5}$ which increases the rate of erythropoiesis. ${ }^{9}$ The research described in this paper was undertaken to determine whether the absorption of iron is controlled by the same hormone(s) that regulates the rate of erythropoiesis. This was studied by measuring the absorption of iron under conditions which we knew would elevate or depress the plasma erythropoietin titer or by introducing exogenous erythropoietin into the animals. While those conditions that elevate the amount of circulating erythropoietin increase iron absorption, and while the converse is also true, the direct test of the hypothesis by use of plasma rich in erythropoietin, or concentrated extracts of such plasma, clearly demonstrated that the erythropoietic factor as such does not directly affect the transport of iron across the gastrointestinal mucosa.

\section{MATERIALS AND METIIODS}

A rapid method for the determination of iron absorption was developed. This procedure is as follows. CF No. 1 female mice, 10 weeks of age, were used. These had been kept on an "iron-free" diet 10 for 2 to 3 days prior to the start of the experiment in order to reduce the amount of non-labeled iron in the gastrointestinal tract and thus to diminish variability that might be due to different dilutions of added labeled iron. The mice were force-fed .4 to $.6 \mathrm{cc}$ of a solution of $\mathrm{Fe}^{59}$ as $\mathrm{FeCl}_{3}$ with added carrier, buffered at $\mathrm{pH} 6$, by means of a $1-\mathrm{ml}$ tuberculin syringe fitted with a curved, 18-gauge needle. The tip of the needle was blunted and smoothed with silver-solder to prevent damage to the esophagus. Immediately after a mouse was force-fed, it was placed in a perforated, 50-ml plastic centrifuge tube which was then tightly corked. The tube was counted in a Welch-Allyn well-type Geiger counter (type H18-20R). Repeated counts were taken at definite intervals until the total-body count per mouse was constant, which then represented the amount of iron absorbed by the animal. At the time when each series of total-body counts was done, $40 \mathrm{ml}$ of a solution containing an amount of $\mathrm{Fe}^{59}$ equal to that given to each mouse was

\footnotetext{
${ }^{*}$ Text of a paper that has been submitted for publication in Blood.
} 
counted to correct for radioactive decay. The iron was diluted to $40 \mathrm{ml}$ so that the geometry of counting was as nearly comparable as possible to that of the mouse. The per cent of the original amount of $\mathrm{Fe}^{59}$ retained by the mouse at various intervals was then calculated from the radioactivity at that interval and the corrected original count for the mouse.

\section{RESULTS}

To test the validity of the method of counting whole mice, the animals were given varying amounts of $\mathrm{Fe}^{59}$ and their radioactivity was determined immediately. The data presented in Figure 1 show a linear relationship between the amount of iron fed and the

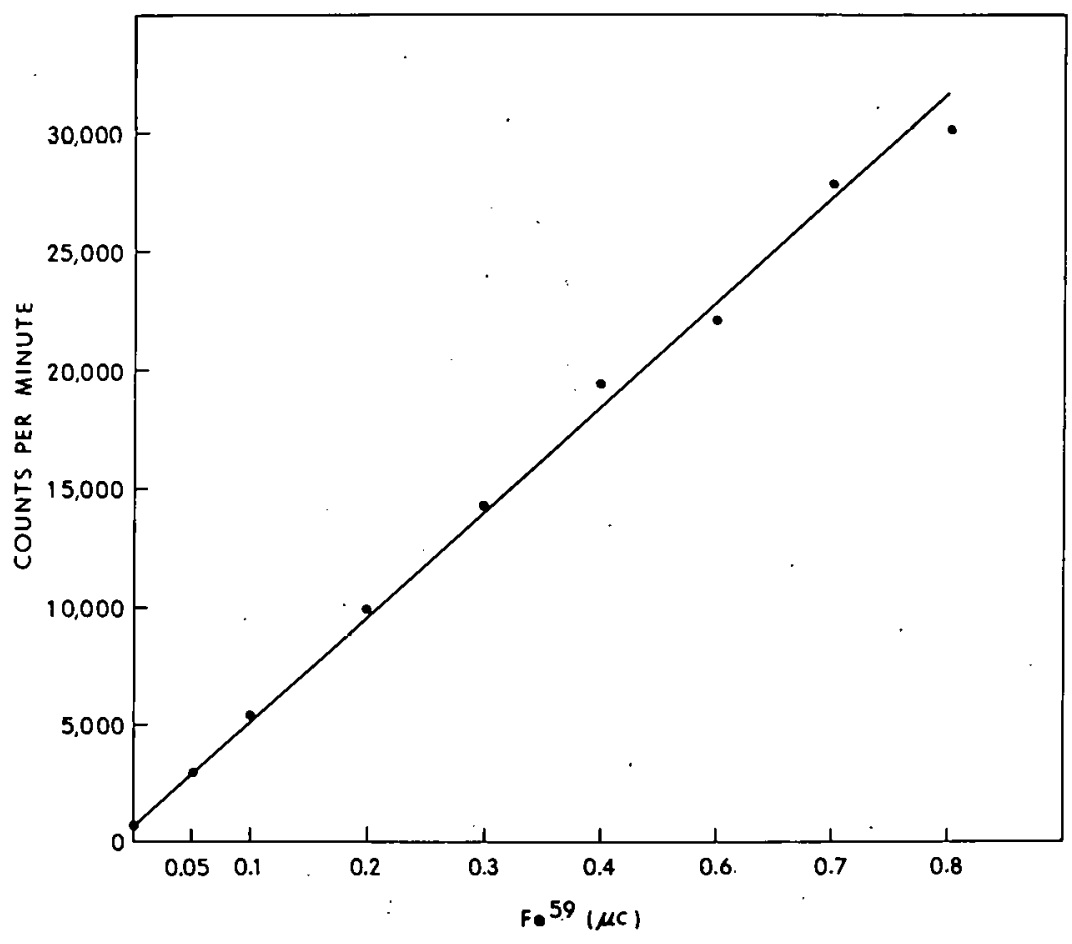

Figure 1. Effect of dose of $\mathrm{Fe}^{59}$ on total-body count rate of mice.

immediate total-body count, an indication that the counting method does measure the relative amount of isotope within the animal.

In another test of the method, we determined how the total-body count was related to the amount of iron that had passed through the mucosa of the gut. Six days after iron feeding, samples of blood were counted, and the results were compared with the total-body counts. As shown in Figure 2, the radioiron found in the blood varied in a linear fashion with the total-body count. In addition, the complete intestinal tract of each animal was excised and counted. No detectable radioiron was found. The evidence thus indicates that the method may be used to measure the absorption of iron.

By our method of determining total-body radioactivity, we easily confirmed earlier 


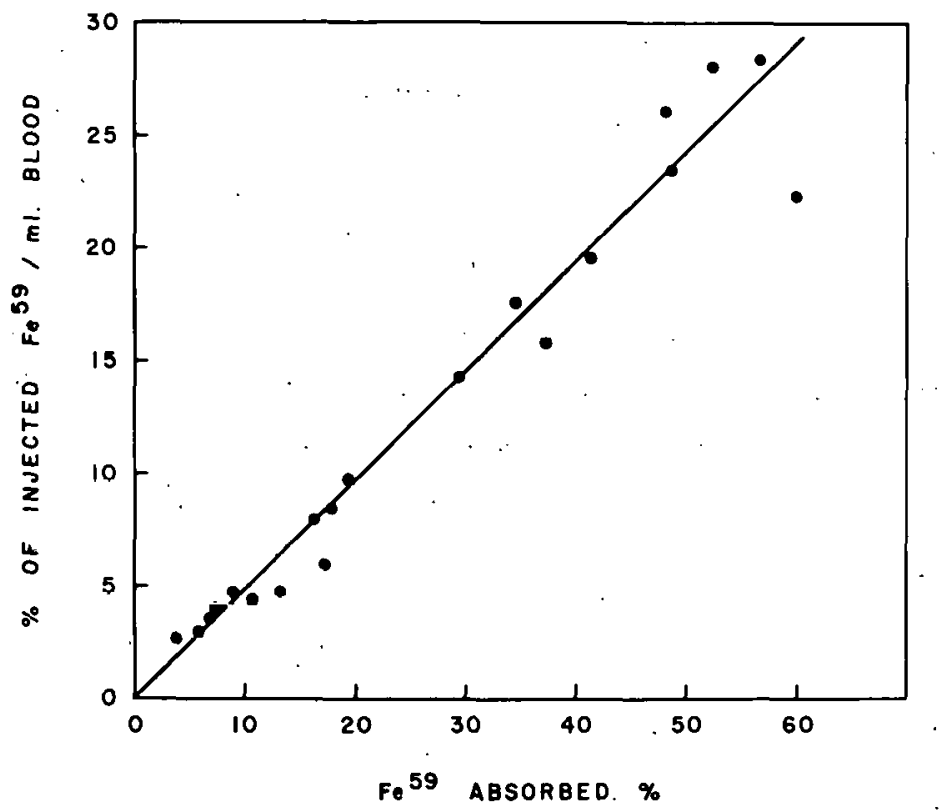

Figure 2. Relationship between blood count rate and total-body count rate.

findings ${ }^{5,6}$ that phlebotomy stimulates iron absorption. Mice had about one-half of their blood volume removed by cardiac puncture 3 days before iron feeding. This was repeated 1 day before iron feeding. The bled and control groups were force-fed $0.6 \mathrm{ml}$ of a 0.006 per cent solution of $\mathrm{FeCl}_{3}$ containing $0.33 \mu \mathrm{C} \mathrm{Fe}^{59}$. The results of this experiment are illustrated in Figure 3. The initial 5-hr. period represents the time before excretion begins. The unabsorbed iron was eliminated quite rapidly, and the leveling of the curve at a constant value represents absorbed iron. It is apparent from the curves that the bled mice retained approximately twice as much iron as did their controls.

Mice treated with $0.8 \mathrm{mg}$ of phenylhydrazine for 3 consecutive days and then with 1.2 $\mathrm{mg}$ on the day preceding administration of $\mathrm{Fe}^{59}$ also showed a marked increase in absorption (Figure 4). The control values are substantially lower than those shown in Figure 3 since a 10-fold larger amount of carrier iron (0.06 per cent; $0.37 \mu$ C) was used.

Atmospheric hypoxia has also been reported to increase iron absorption, ${ }^{11}$ and we have found this to be true with our assay system. Ten mice were placed in an atmosphere containing 8 to 10 per cent oxygen for $21 \mathrm{hrs}$. and 10 others were used as controls. At the end of this period both groups were given the $\mathrm{Fe}^{59}$ orally. The results in Table 1 demonstrate an increased absorption by the animals made hypoxic.

'Since phenylhydrazine, bleeding, and atmospheric hypoxia are all followed by an increased plasma erythropoietin titer, $, 9,12$ and since it has been shown that cobaltous ion can also induce a rise in plasma erythropoietin, ${ }^{13}$ we tested the effect of cobalt on iron absorption. Eight mice were injected subcutaneously for 3 days with $5.3 \mu \mathrm{M}$ of $\mathrm{CoCl}_{2}$ in. - $0.1 \mathrm{ml}$ saline per day, while control mice were given saline. On the fourth day, the animals 


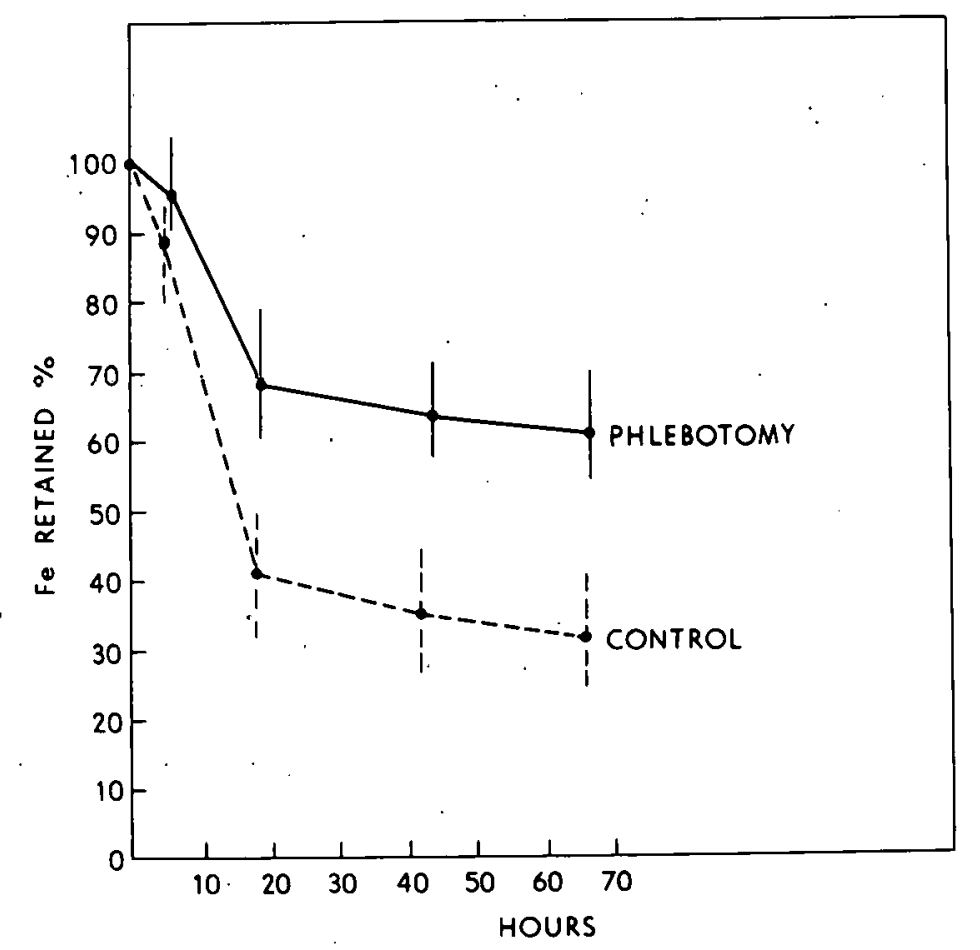

Figure 3. Effect of phlebotomy on Fe absorption.

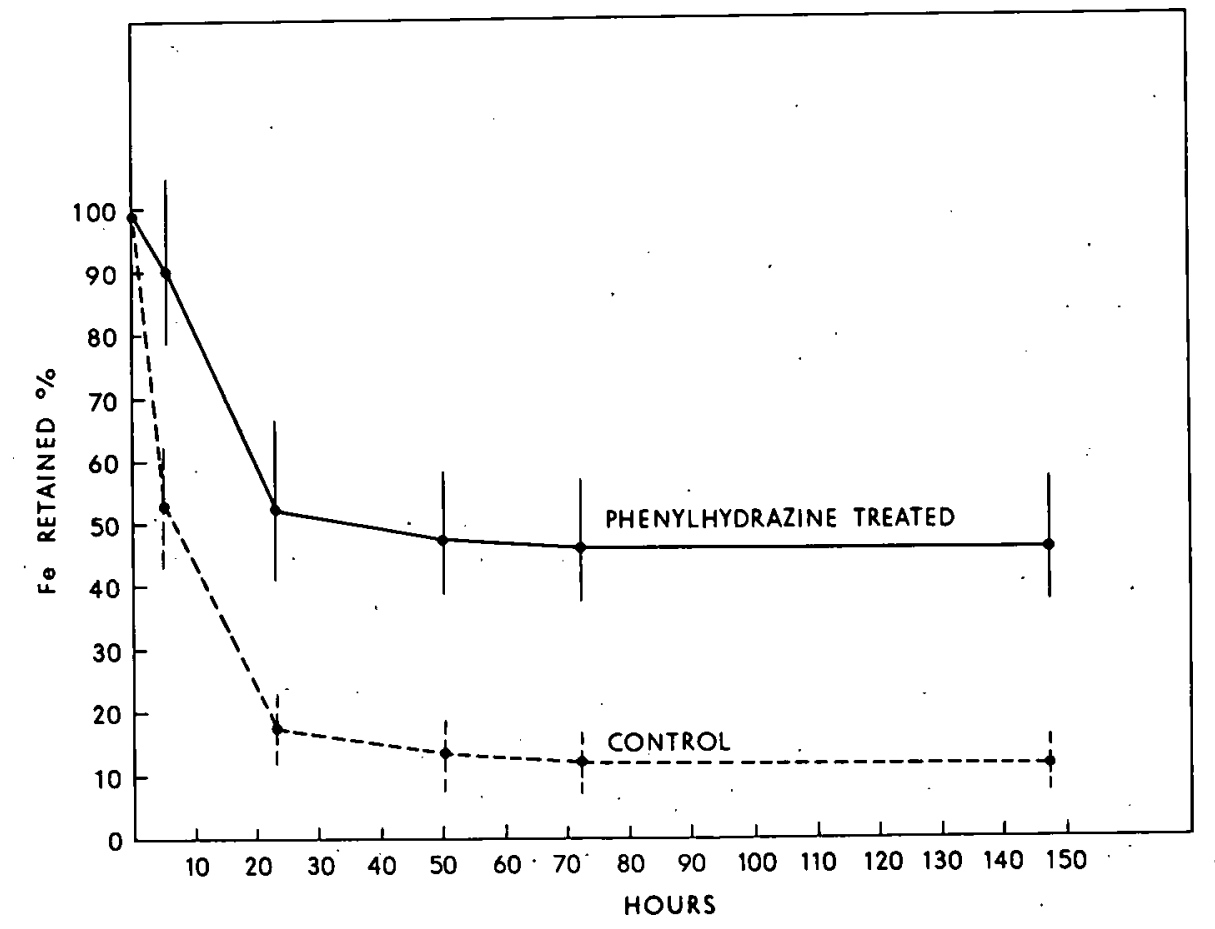

Figure 4. Effect of intravenous hemolysis on $\mathrm{Fe}$ absorption. 
Table 1

EFFECT OF ERYTHROPOIETIC STIMULATION ON IRON ABSORPTION

\begin{tabular}{cccc}
\hline $\begin{array}{c}\text { Mice } \\
(\text { No. })\end{array}$ & $\begin{array}{c}\text { Time } \\
(\text { Hrs.) }\end{array}$ & \multicolumn{1}{c}{ Treatment } & Fe $\begin{array}{c}\text { Absorbed } \\
(\%)\end{array}$ \\
\hline 10 & 96 & Control & $7.5 \pm 1.4^{*}$ \\
10 & Hypoxia & $17.9 \pm 6.0$ \\
\hline 9 & \multirow{2}{*}{168} & Control - NaCl & $9.7 \pm 5.2$ \\
9 & Cobaltous Chloride & $31.1 \pm 11.6$ \\
\hline
\end{tabular}

* Standard deviation of the mean.

were force-fed $\mathrm{Fe}^{59}$ and the per cent absorption was determined. As indicated in Table 1, . cobaltous ion appreciably increased the absorption of iron.

Another parallelism between iron absorption and rate of erythropoiesis is seen in Table 2. Mice were made polycythemic by 11 injections of $0.5 \mathrm{ml}$ of an 80 to 90 per cent suspension of homologous red cells in saline over a period of 3 .weeks, at which time their hematocrits were 70 to 80 per cent. Erythropoiesis is completely depressed in such mice. 9 One group of polycythemic mice was given cobalt ion as in the previous experiment. The other group was given saline, and the results from these two groups were compared with those from normal mice given cobalt ion and saline.

Table 2

EFFECT OF INDUCED POLYCYTHEMIA AND COBALTOUS ION ON IRON ABSORPTION

\begin{tabular}{|c|c|c|c|}
\hline $\begin{array}{l}\text { Mice } \\
\text { (No.) }\end{array}$ & $\begin{array}{l}\text { Time } \\
\text { (Hrs.) }\end{array}$ & Treatment & $\begin{array}{c}\mathrm{Fe}^{59} \text { Absorbed } \\
(\%)\end{array}$ \\
\hline 5 & \multirow{4}{*}{96} & Normal Control - $\mathrm{NaCl}$ & $8.4 \pm 3.5 *$ \\
\hline 6 & & Polycythemic Control - NaCl & $0.7 \pm 0.3$ \\
\hline 5 & & Normal $\mathrm{Co}^{++}$ & $21.8 \pm 4.8$ \\
\hline 6 & & Polycythemic $\mathrm{Co}^{++}$ & $3.5 \pm 3.3$ \\
\hline
\end{tabular}

Polycythemia reduced drastically the absorption of iron, and while cobalt had a pronounced effect on the normal mouse, it had a very slight net effect on the polycythemic mice. In these cobalt-treated, polycythemic mice, erythropoiesis was mildly accelerated as shown by a rise in reticulocytes from zero in the untreated animals to 0.1 to 0.4 per cent in the cobalt-treated groups.

The very dramatic effect of cobalt ion seen in the groups of normal mice is obviously not due to the toxic'action of the metal ion on the gastrointestinal mucosa, which might 
increase the transport of iron. If toxicity were involved; the magnitude of response would 'be expected to be about the same in the polycythemic group as in the normal group. Similar results have been reported by Bothwell et al. ${ }^{14}$

The effect of iron-loading of the mice on absorption of dietary iron was determined after injection of iron-dextran (Imferon). It is readily seen that excess body iron drasti- . cally reduces the absorption of iron by the gastrointestinal mucosa.

An attempt was also made to dissociate erythropoiesis from iron absorption by $X$ ir radiation. We hoped to depress marrow function and observe the effect upon absorption. In a preliminary experiment, mice that had been exposed to $20.0 \cdot \mathrm{r} 36 \mathrm{hr}$. before being force-fed $\mathrm{Fe}^{59}$ showed about a 2 -fold increase in iron absorption (controls, 13 per cent; irradiated, 34 per,cent). However, subsequent experiments have shown a wide scatter of effect including a depression of iron absorption induced by $\mathrm{X}$ irradiation. These results may be due to radiation-induced mucosal damage and have dissuaded us from further efforts along this line.

In another attempt to depress marrow function without deleterious effects to the gastrointestinal mucosa, we treated mice with Myleran or $\mathrm{Ca}^{45}$. Myleran generally made the animals too sick to be useful, and $\mathrm{Ca}^{45}$ was of such low specific activity that by the use of physiologically tolerated amounts, the rate of erythropoiesis, as determined by reticulocyte count, was never greatly diminished until the animals died.

Table 3

EFFECT OF IRON-LOADING ON IRON ABSORPTION

\begin{tabular}{rccc}
$\begin{array}{c}\text { Mice } \\
(\text { No.) }\end{array}$ & $\begin{array}{c}\text { Time } \\
\text { (Hrs.) }\end{array}$ & Treatment & $\begin{array}{c}\text { Fe } \\
\text { Absorbed } \\
(\%)\end{array}$ \\
\hline 8 & & Control $-\mathrm{NaCl}$ & $7.7 \pm 2.2 *$ \\
10 & 96 & Imferon - 11 days & $1.7 \pm 0.6$ \\
14 & & Control - $\mathrm{NaCl}$ & $14.2 \pm 4.9$ \\
15 & & Imferon - 4 days & $2.5 \pm 1.0$ \\
\hline
\end{tabular}

Eight mice given injection of Imferon ( $0.5 \mathrm{mg}$ iron equivalent) for times indicated. Control mice injected with saline at same times. After last injection, tracer amount given by stomach tube and per cent absorption measured.

* Standard deviation of the mean.

The hypothesis that erythropoietin may exert a direct effect upon. iron absorption was tested by using a concentrated extract of plasma from rabbits made severely anemic by. phenylhydrazine. This extract, made by perchloric acid precipitation of the plasma ${ }^{13}$ when assayed at $12 \mathrm{mg}$ per rat per injection. in starved animals by the iron incorporation method, ${ }^{15}$ induced an $\mathrm{Fe}^{59}$ incorporation value of 10.6 per cent, while the control value (saline or normal plasma) was 3.7 per cent. This material could also stimulate reticulocyte formation in polycythemic mice. Polycythemic mice given $51 \mathrm{mg}$ per mouse of the anemic 
plasma extract over a 3-day period before iron feeding had a 2.6 per cent absorption as compared with 2.1 per cent for control mice (Table 4). In addition, whole plasma from mice treated with cobaltous ion, a method known to increase erythropoietin titer $s,{ }^{13}$ failed to significantly increase iron absorption in polycythemic mice. Mice given $5 \mathrm{cc}$ per mouse of "cobalt plasma" over a period of 5 days had an iron absorption of 4.5 per cent, while those given normal plasma absorbed 3.7 per cent (Table 4). Mice with transfusion-induced polycythemia were used in these experiments in order to determine whether there was a direct effect on the mucosa independent of active erythropoiesis. In view of the magnitude of error in these measurements, the slightly higher values seen with both of the above experimental series cannot be considered good enough evidence to indicate stimulated absorption.

Table 4

EFFECT OF ERYTHROPOIETIN ON IRON ABSORPTION

\begin{tabular}{|c|c|c|c|}
\hline $\begin{array}{l}\text { Mice } \\
\text { (No.) }\end{array}$ & $\begin{array}{l}\text { Time } \\
\text { (Hrs.) }\end{array}$ & Treatment & $\mathrm{Fe}^{59} \underset{(\%)}{\text { Absorbed }}$ \\
\hline \multirow{2}{*}{$\begin{array}{l}3 \\
8\end{array}$} & \multirow{2}{*}{72} & Polycythemia - NaCl & $2.1 \pm 0.1 *$ \\
\hline & & $\begin{array}{l}\text { Polycythemia + anemic } \\
\text { plasma extract }\end{array}$ & $2.6 \pm 1.8$ \\
\hline 10 & \multirow{2}{*}{144} & $\begin{array}{l}\text { Polycythemia + normal } \\
\text { plasma }\end{array}$ & $3.7 \pm 1.5$ \\
\hline 9 & & Polycythemia. $+\mathrm{Co}^{++}$plasma & $4.5 \pm 2.7$ \\
\hline
\end{tabular}

* Standard deviation of the mean.

The idea expressed by Bothwell et al. ${ }^{14}$ that iron absorption appears to parallel the rate of erythropoiesis seems to be valid in light of our findings. However, the question still remains as to how the intestinal mucosa is stimulated by increased erythropoiesis. The possibility that the absorbing mucosal surface responds to a simple displacement of the equilibrium between tissue cells and plasma by a fall in plasma iron would require a separate compartment of iron in the plasma to which the mucosa would respond. This would have to be the case because the total iron in the plasma of animals made anemic by hemolysis is greater than that in normal animals. Data presented by Borsook ${ }^{16}$ indicate that siderophilin does increase in the hypoxic animal. We have, so far, been unable to demonstrate any humoral factor that affects the intestine as a consequence of alterations in the marrow; nor any.humoral factor that affects both concomitantly: If such a.humoral factor exists, it does not appear to be erythropoietin. The possibility remains that the intestine is acted on directly by the same external conditions that alter the rate of erythropoiesis, the most apparent of which is hypoxia. 
A new method for the study of gastrointestinal absorption of iron in mice has been described. Phlebotomy, intravenous hemolysis, hypoxia, and cobaltous ion increase iron absorption. Transfusion-induced polycythemia depresses iron absorption in mice. Ironloading by means of Imferon also depresses iron absorption. Under the conditions described for these experiments, exogenous plasma erythropoietin has no direct effect on iron absorption.

\section{LITERATURE CITED}

1. Hahn, P. F., W..F. Bale, E. O. Lawrence, and G. W. Whipple. J. Exper. Med., 69: $739,1939$.

2. Granick, S. Science, 103:107, 1946.

3. Drabkin, D. L. Physiological Reviews, 31:345, 1951.

4. Granick, S. Physiological Reviews, 31:489, 1951.

5. Stewart, W. B., C. L. Yuile, H. A. Claiborne, R. T. Snowman, and G. H. Whipple. J. Exper. Med., 92:375, 1950.

6. Hahn, P. F., W. F. Bale, J. F. Ross, W. M. Balfour, and G. H. Whipple. J. Exper. Med., 78,169, 1943 .

7. Kaldor, I. Australian Journal of Exp. Biol. and Med. Science, 32 (6):801, 1954.

8. Stewart, W. B., P. S. Vassar, and R. S. Stone. J. Clin. Invest., 32:1225, 1953.

9. Jacobson, L. O., E. Goldwasser, L. F. Plzak, and W. Fried: Proc: Soc. Exp. Biol. Med., 94:243, 1957 .

10. Wissler, R. W., R. L. Woolridge, C. H. Steffee, Jr., and P. R. Cannon. J. Immunology, $52: 267,1946$.

11. Vassar, P. S., and D. M. Taylor. Proc. Soc. Exp. Biol. Med., 93:5904, 1956.

12. Stohlman, F., and G. Brecher. VIth Congress, International Society of Hematology, p. 459, August, 1956.

13. Goldwasser, E., L. O. Jacobson, W. Fried, and L. Plzak. Blood, 12:55, 1958.

14. Bothwell, T. H., G. Pirzio-Biroli and C. A. Finch. J. Lab. Clin. Med.,. 51:24, 1958.

15. Fried, W., L. F. Plzak, L. O. Jacobson, and E. Goldwasser. Proc. Soc. Exp. Biol. Med., $94: 237,1957$.

16. Colehour, J. K., H. Borsook, and A: Graybiel. Am. J. Physiology, 191:113;1957. 


\section{STUDIES ON ERYTHROPOIESIS: XV. THE PREPARATION OF A HIGHLY}

PURIFIED ERYTHROPOIETIN FROM ANEMIC SHEEP PLASMA

By

W. F. White, ${ }^{*}$ R. Egan, ${ }^{\dagger}$ R. J. Schlueter, ${ }^{*}$.G. F. Weber, ${ }^{*}$ and E. Goldwasser ;

\section{INTRODUCTION}

Although the usual source of plasma with a high erythropoietin titer has been the rabbit, it became evident that only a larger animal would yield sufficient plasma for us to carry through a fractionation scheme and still have enough product to characterize physically and chemically. We also planned to collect plasma and prepare enough purified product for clinical evaluation of erythropoietin.

As means to these ends, we first investigated fractions derived both from pooled normal human plasma that could be made available if needed and from normal bovine plasma that was available in unlimited quantities from the packing house. Neither of these normal plasmas had enough erythropoietic activity to warrant further work on isolation of the hormone. Thus we turned to anemic plasma as a source material and chose cull breeder sheep as the cheapest large animal available.

\section{MATERIALS AND METHODS}

Assay. The method used was that of Fried et al. ${ }^{1}$. Rats were starved 30 hours prior to the first injection of sample.

Two levels of cobaltous chloride, $5 \mu \mathrm{M}$ and $10 \mu \mathrm{M}$, were used in each assay to supply uniform reference values. The response to the lower level of cobalt was arbitrarily designated as one unit of activity. This value was consistently found to be in the range of 3.2 to 4.4 per cent net uptake of iron (i.e., with saline value subtracted). Dose-response curves for plasma, purified fractions, and cobalt were linear up to the value for $10 \mu \mathrm{M}$ cobalt $(6.4$ to 9.0 per cent net uptake), but appeared to level off above that amount of cobalt. For this reason, units were calculated only when the value fell between those for the two cobalt levels.

An accurate comparison was made of the erythropoietic activities of plasma from normal sheep and one known to be active from anemic sheep. Normal plasma contained 0.08 $\mathrm{u} / \mathrm{ml}$ of erythropoietin, whereas the anemic plasma had $16 \mathrm{u} / \mathrm{ml}$. Since anemic plașma can be 200 times as potent as normal plasma, we eliminated normal sheep plasma from consideration as an economical source of erythropoietin (unless a highly specific method can be found for concentrating the factor).

*Research Division, Armour and Company, Chicago, Illinois.

${ }^{\dagger}$ Present address: Ortho Research Foundation, Raritan, New Jersey. 
Production of high-titer plasma in sheep. Preliminary experiments on cull breeder sheep showed that a weight-adjusted phenylhydrazine dose in the range of that used with rabbits, ${ }^{*}$ administered in 3 portions, produced active plasma over a 6 -day period. However, presumably because of greater variability among the sheep, there were irregularities in the response of the animals to a standard dose schedule; about $1 / 3$ of the animals died before the end of the 6 th day and about $1 / 3$ produced plasma of very low titer. Frequent assays were then made on the plasmas from individual sheep to assess the importance of the state of anemia attained in the animal before collecting the blood. The results are plotted as potency versus hematocrit values at time of sacrifice (Figure 1). It appears

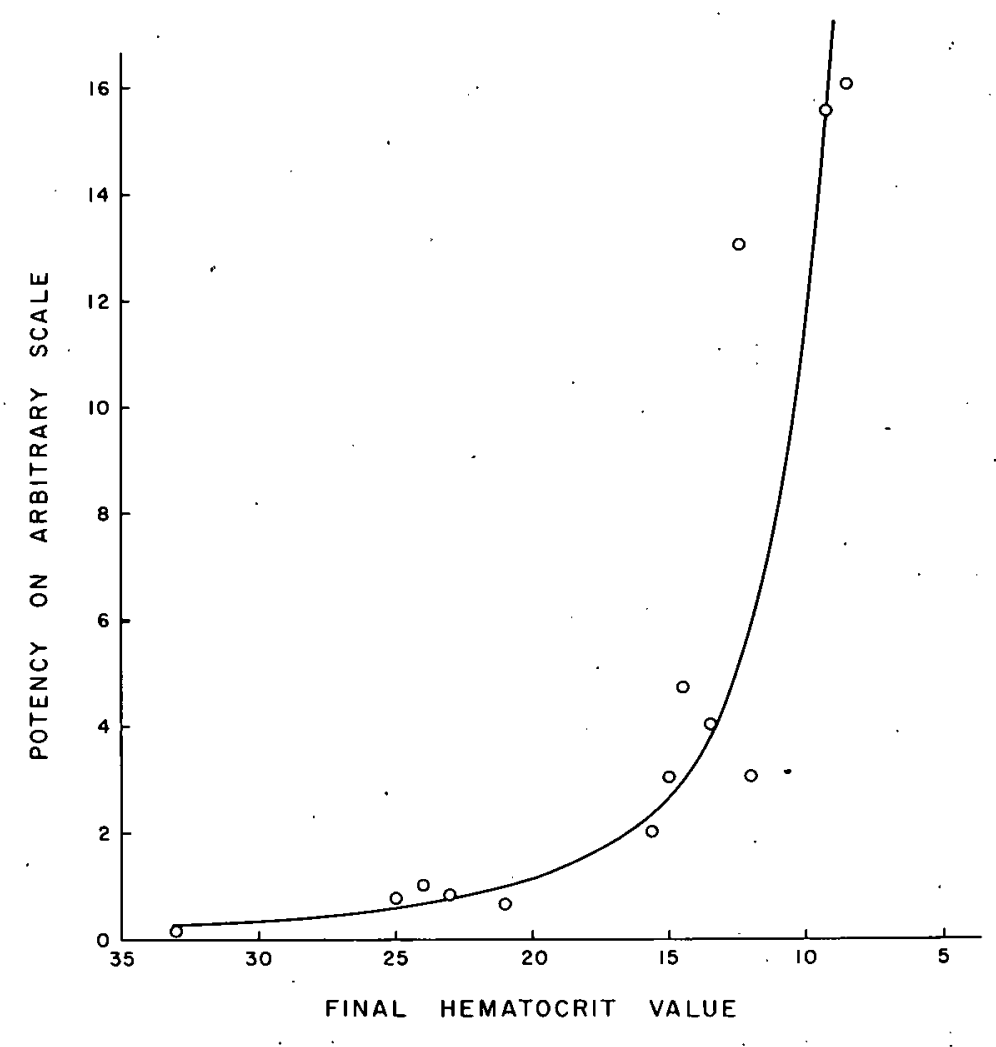

Figure 1. Relationship between final hematocrit. values and plasma potency.

that the curve is logarithmic in character, with potency increasing to a remarkable degree as the hematocrit value approaches 10 per cent. As a result of these data, a schedule was set up in which the first 2 doses of phenylhydrazine were based on the weight-of the animal and its initial. hematocrit value and the $3 \mathrm{rd}$ was based on the degree of anemia (hematocrit value) that developed by the 5th day. In this way, the hematocrit value of more animals is in the desired range on the day of sacrifice (6th). By the introduction of this refinement,

* Jacobson and his co-workers used approximately $44 \mathrm{mg}$ of phenylhýdrazine per $\mathrm{kg}$ for rabbits, dividing the dose into 7 parts given over 7 consecutive days. 
the potency of the pooled plasmas from large groups (20 animals each) has been raised from 0.5 to nearly $1.0 \mathrm{u} / \mathrm{ml}$.

\section{EXPERIMENTAL RESULTS}

First-step fractionation. Most workers have removed the inert proteins of plasma by boiling, according to the method described by Borsook et al. ${ }^{3}$ By this method, however, only a very dilute product with a volume about 5 times that of the original plasma is obtained. In addition, yields of activity are low and inconsistent, averaging only about 25 per cent 'in our hands.

Both alcohol $^{*}$ and ammonium-sulfate fractionation were tried as the first step in attempts to remove proteins from the plasma. Both methods yielded active supernatants, but in each the activity was low and the processes were lengthy and complicated.

At this point, attention was turned to the use of the anion-exchange adsorbent DEAEcellulose, which had been found useful for the fractionation of serum proteins. ${ }^{4}$ At first, unmodified plasma was used in an attempt to hold preliminary changes to a minimum. At physiologic salt concentration $(0.15 \mathrm{M} \mathrm{NaCl})$, it was found that none of the activity was held by the exchanger ${ }^{\dagger}$ at any $\mathrm{pH}$ between 4.2 and 8.5 , a range that coincides roughly with limits for effective use of DEAE-cellulose. Further experiments were tried at 1:1 0.075

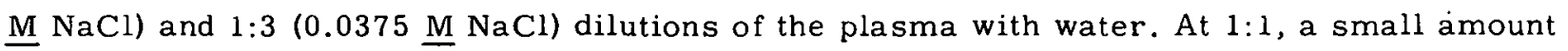
of activity was adsorbed on the column, and at 1:3, most of the activity was held withuut much variation over the $\mathrm{pH}$ range. In the case of the 1:3 dilutions; the amount of material recovered by thorough elution of the DEAE-cellulose, as estimated by optical-density measurements, varied from $0.5 \mathrm{~g} / 1$ to more than $15 \mathrm{~g} / 1$, with the lowest amount at $\mathrm{pH} 4.5$. For this reason, 4.5 was selected as the best $\mathrm{pH}$ for adsorption of the factor. In repeated experiments it was found possible to adsorb erythropoietin quantitatively from 1 liter of plasma onto $10 \mathrm{~g}$ of DEAE-cellulose at $\mathrm{pH} 4.5$ and $0.0375 \mathrm{M}$ salt concentration. $\neq$ After thorough washing of the adsorbent, at least $50 \%$ of the activity could be eluted with $0.1 \mathrm{M}$ $\mathrm{Na}_{2} \mathrm{HPO}_{4}-0.5 \mathrm{M} \mathrm{NaCl}$. The operation could be done either on columns or in batches, and, if with columns, yielded a concentrated solution of erythropoietin in a volume less than 0.1 that of the original plasma. About $0.4 \mathrm{mg}$ of dialyzed and lyophilized material was obtained from each $\mathrm{ml}$ of plasma, about 20 per cent of that obtained by the boiling process. The lyophilized product was light buff in color and was freely soluble in water, giving an opalescent solution. It will henceforth be referred to as Step 1 material.

* Traces of activity were found in the supernatants from Fraction $V$ (Cohn) from both normal human and normal bovine plasmas. By moving directly to the precipitating conditions for Fraction V, using anemic plasma, more active supernatants were obtained. However, the yields of activity were low.

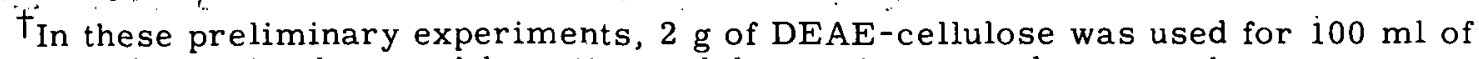
heparinized anemic plasma. Adsorption and desorption were done on columns.

FThe salt concentration was lowered by dialysis or dilution. 


\section{Properties of Step 1 material.}

1. Electrophoresis. Analysis of Step 1 material by moving boundary electrophoresis at $\mathrm{pH} 8.5$ in $0.1 \mathrm{M}$ veronal buffer showed 2 peaks with mobilities of about 6.2 and $4.6 \times 10^{-5} \mathrm{~cm}^{2} / \mathrm{v} / \mathrm{sec}$, respectively. The faster peak is always larger than the other in a ratio of about 2 to 1 . Figure $2 \mathrm{~A}$ shows a typical electrophoretic pattern. At $\mathrm{pH} 4.4,2$ peaks are again evident, although the separation is less obvious (Figure 2B).

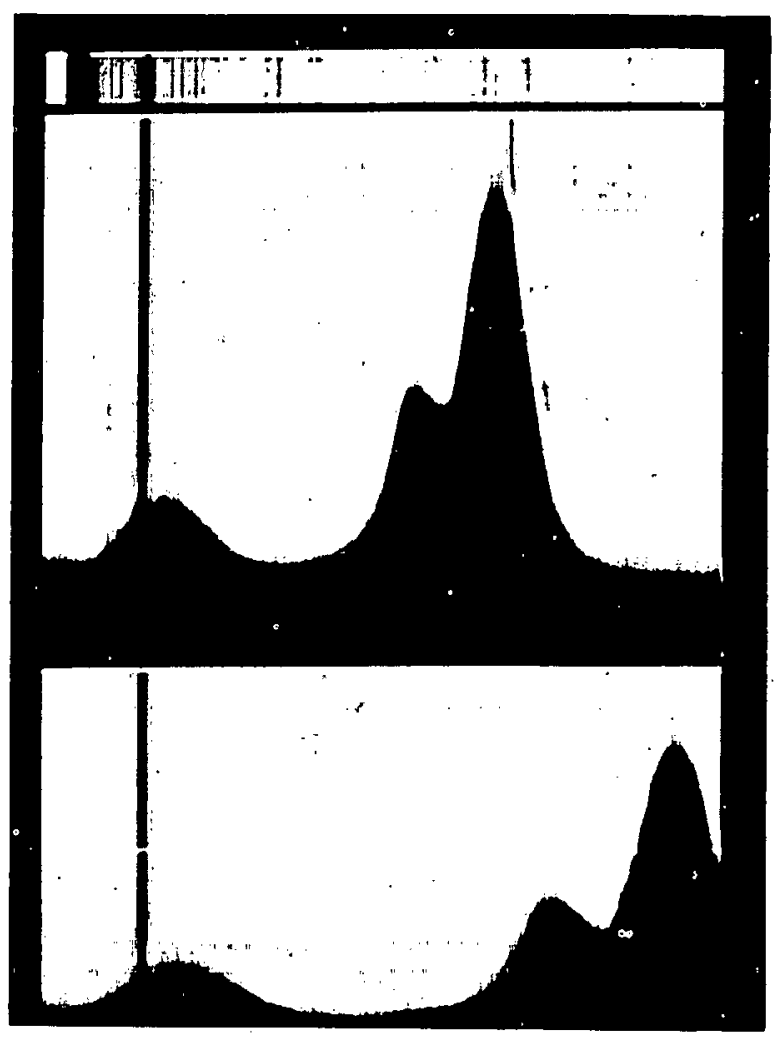

A

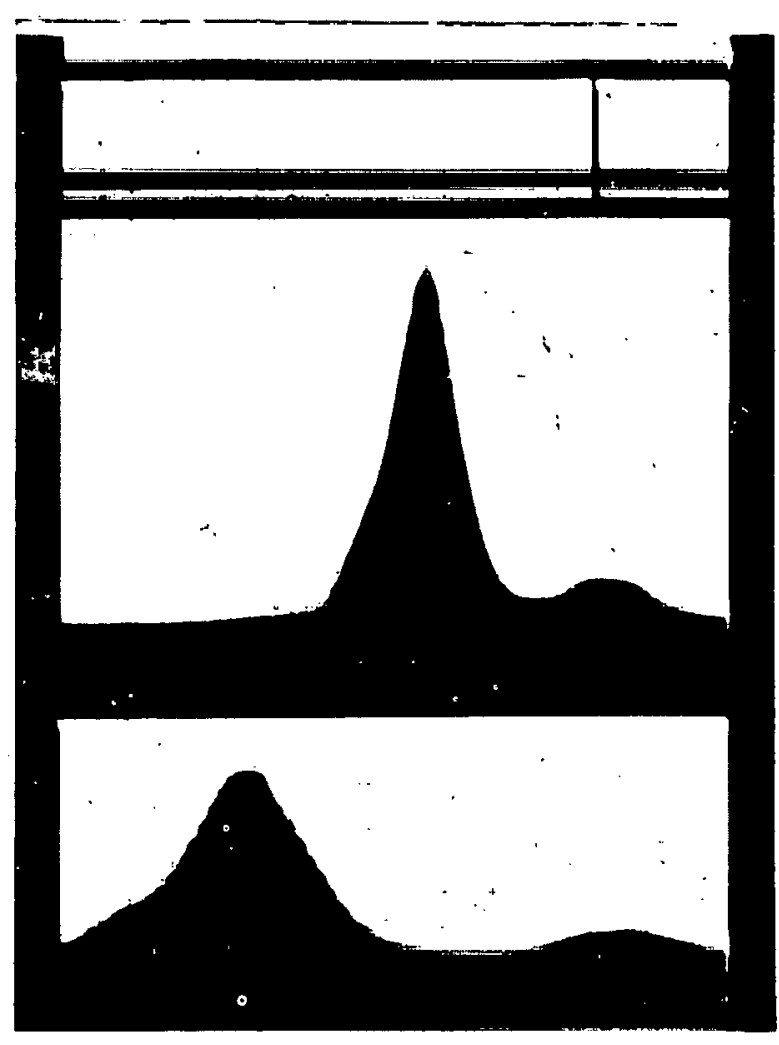

B

Figure 2. Electrophoresis of step 1 sheep erythropoietin.

A. pH 8.5, 0.1 M veronal buffer, $60 \mathrm{~min}$. (upper) and $90 \mathrm{~min}$. (lower), ascending limb.

B. $\mathrm{pH} 4.4,0.05 \underline{\mathrm{M}}$ acetate buffer, $60 \mathrm{~min}$. (upper) and $120 \mathrm{~min}$. (lower) descending limb.

2. Fractional electrical transport. ${ }^{5}$ In preliminary tests, it was found that the ultraviolet absorbing part of Step 1 material concentrated in the cells near the anode; with equilibrium $\mathrm{pH}$ values of about 3.7. Assays showed that all the activity was also concentrated in these cells. Re-running of the anodic material did not alter the behavior. Thus, erythropoietin appeared to be acidic in character and isoionic at about $\mathrm{pH} 3.7$.

3. Test for anaphylactic reaction in guinea pigs. In order to gain preliminary information about the suitability of sheep erythropoietin concentrates for repeated in- 
jection into other species, including human beings, Step 1 material was tried in the standard guinea pig test. ${ }^{6}$ A sample of crude anemic plasma was tested as a reference. Sensitizing doses were given intraperitoneally at $2 \mathrm{mg}$ of protein, and shocking doses were given intravenously 3 weeks later at a level of $20 \mathrm{mg}$ of protein per animal. Control guinea pigs were given shocking doses only. The results are shown in Table 1. It is apparent that both materials are highly antigenic.

Table 1

GUINEA PIG ANAPHYLACTIC TEST

(700-g male animals used)

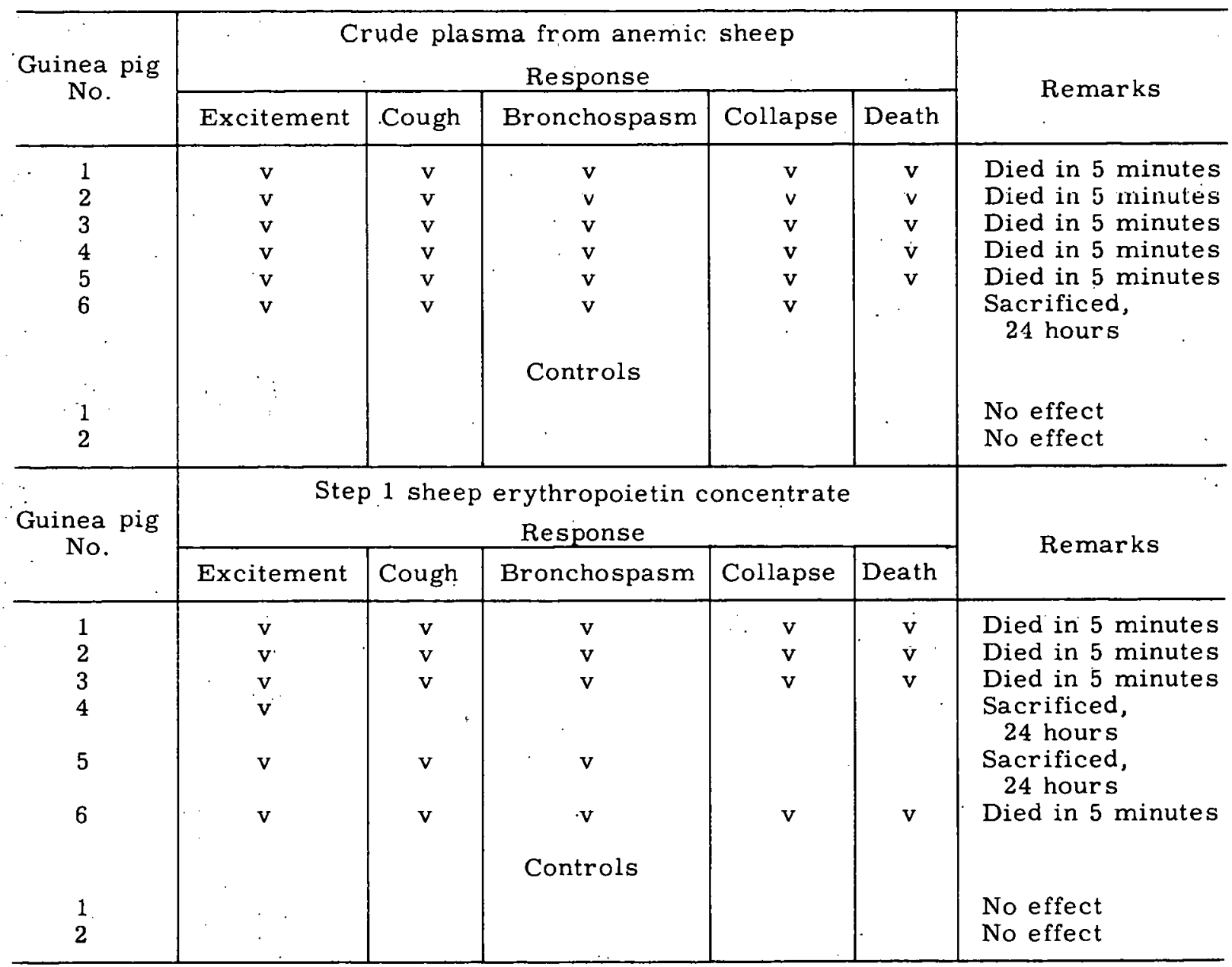

Further fractionation of Step 1 material.

1. Precipitation by ammonium sulfate and alcohol. Preliminary experiments showed that active precipitates begin to form at 60 per cent saturation with ammonium sulfate and that precipitation of activity is complete at full saturation. However, since no point was found at which a high purification was obtained, work was sus- 
pended on this method.

Ethanol in the cold proved to be a somewhat more selective agent. In this work, an additional fractionation could often be obtained by making use of the differential solubility of the alcohol precipitates in acidified water. By. precipitating Step 1 material at 60 per cent ethanol at $\mathrm{pH} 2.0$ and extracting the precipitate with acid water ( $\mathrm{pH} 2.0$ ), a residue exhibiting a single electrophoretic peak was obtained. However much of the activity was lost, and the produce was still moderately anaphylactic.

2. Re-use of DEAE-cellulose. Step 1 material was re-applied to DEAE-cellulose

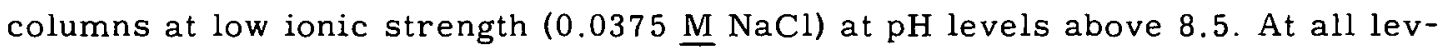
els, some of the optical density ( 10 to 15 per cent) passed directly through the column, presumably representing material incompletely washed out in the original elution. By application of a $\mathrm{NaCl}$ gradient, a main peak (40 to 60 per cent of

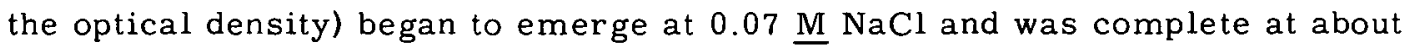
$0.2 \mathrm{M}$. Another peak, exhibiting about 7 to 15 per cent of the original optical density, could then be removed with $0.1 \underline{\mathrm{M} N a}{ }_{2} \mathrm{HPO}_{4}-0.5 \underline{\mathrm{M}} \mathrm{NaCl}$. At certain $\mathrm{pH}$ values the main peak gave slight evidence of a shoulder on the trailing edge, but in no case was a clear separation into 2 peaks seen. Material from the leading edge of the main elution peak contained a small amount of a second electrophoretic component (Figure 3A), and material from the trailing edge was enriched in the slower electrophoretic peak (Figure $3 \mathrm{~B}$ ). The potency was greater in the leading edge of the peak, suggesting that the faster electrophoretic component is the active one.

Figure 4 shows the results of a typical second-stage DEAE experiment. The recovery in activity across the peak eluted after the gradient was applied was about 70 per cent. Findings from an anaphylactic test of the inert fractions $A$ and $F$ and the highly potent fraction $B$ indicated that impurities were responsible for the severe reactions to Step 1 material. Only 1 animal showed a severe reaction to fraction $B$, whereas 2 of 5 treated with fraction $A$ died, and 5 of 5 with frac- . tion $\mathrm{F}$.

Thus a process involving 2 successive elutions on a DEAE column gave promise of producing material suitable for clinical use. However, failure to separate the slower, and apparently inert, electrophoretic component quantitatively was a drawback.

In attempting to assess the purification achieved by rewashing Step 1 material through DEAE-cellulose, 2 criteria were applied in addition to electrophoresis:

(a) Re-application (3rd stage) to DEAE-cellulose. Figure 5 shows the curve obtained after subjecting the most potent fraction from a re-run DEAE column (Fraction B, Figure 4) to a 3rd passage through DEAE-cellulose. The same $\mathrm{pH}$ (5.5) was used as in the second manipulation. Only very little optical density passed directly through the column, and a very smooth elution peak was obtained 


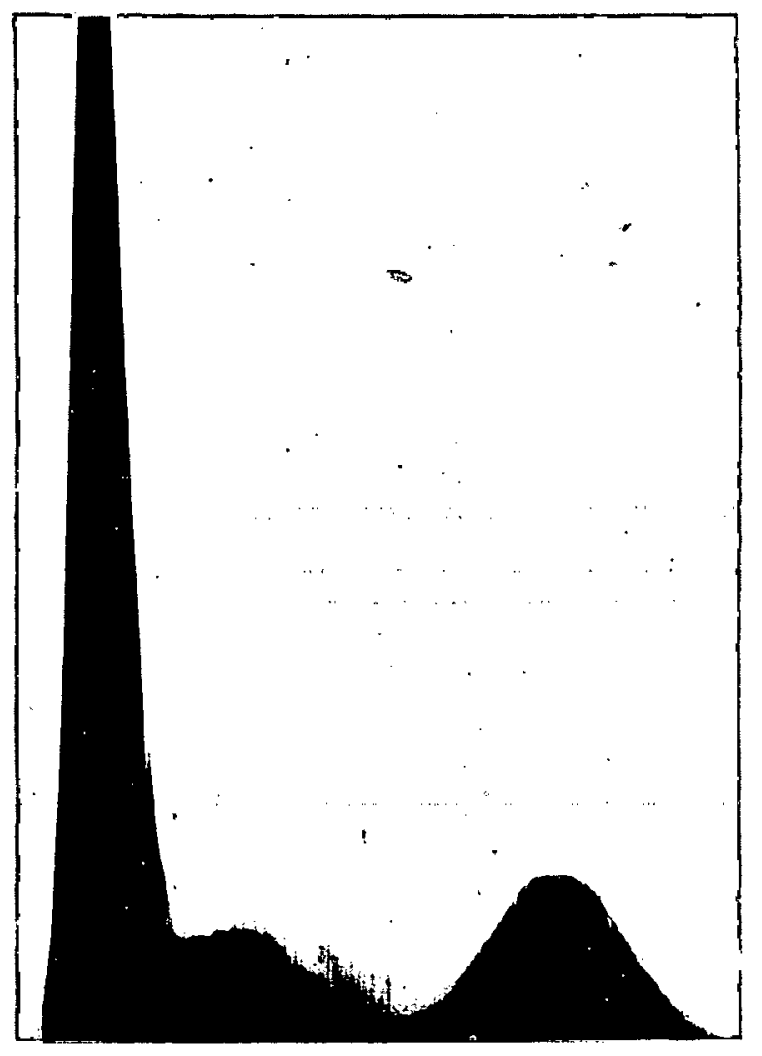

A

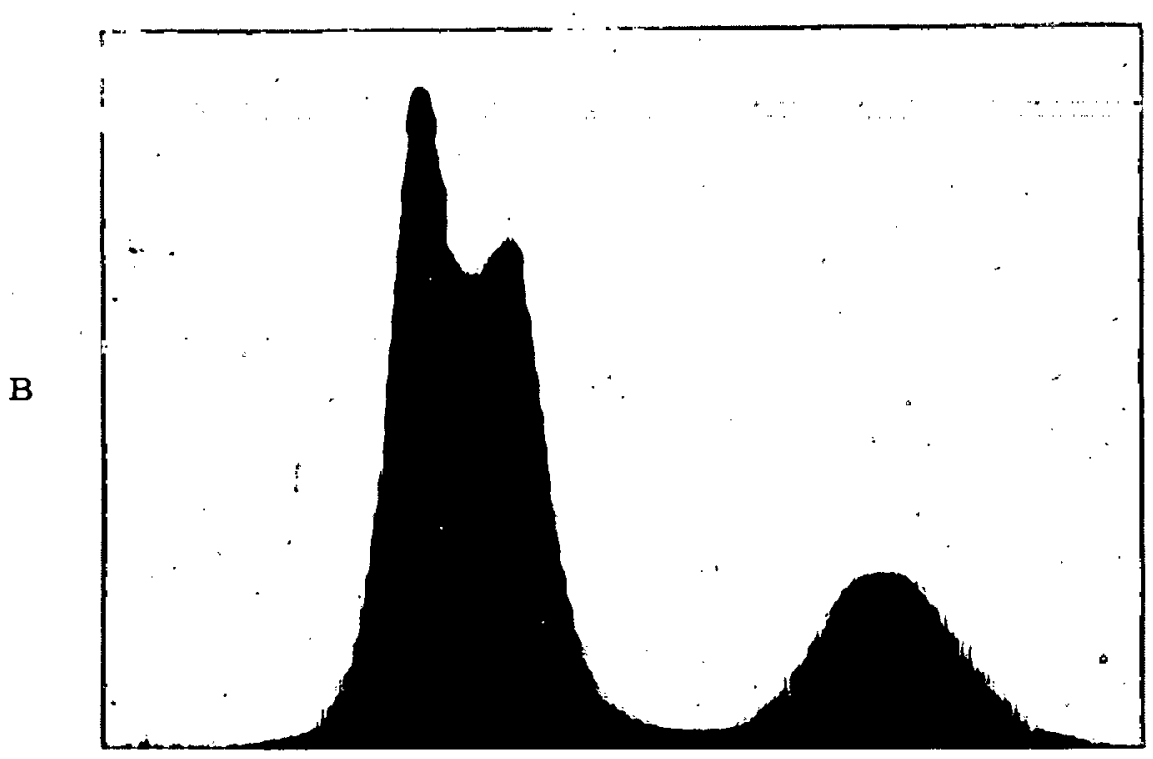

Figure 3. Electrophoresis of second stage DEAE eluate. $\mathrm{pH} 8.6,0.1 \underline{\mathrm{M}}$ veronal buffer, $100 \mathrm{~min}$.

A. Leading edge of main chromatographic peak.

B. Trailing edge of main chromatographic peak. 

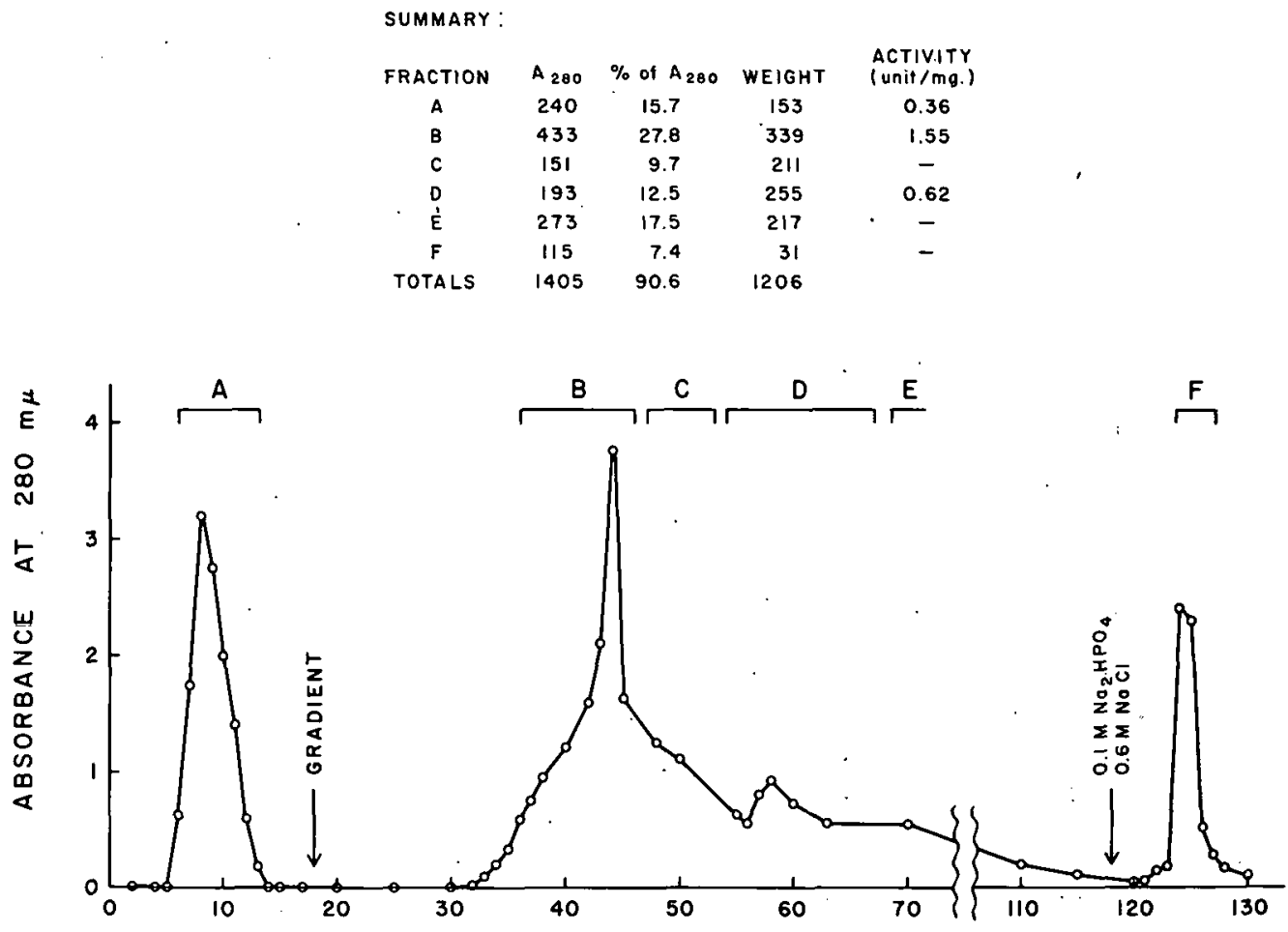

Figure 4. Re-run of Step 1 material on DEAE-cellulose at pH 5.5. The sample $(2.0 \mathrm{~g} \mathrm{~K}-053-\mathrm{C})$ in $100 \mathrm{ml}$ buffer was applied to a column $11 \mathrm{~cm}$ high $\times 3.4 \mathrm{~cm}$ diam. The total optical density of the sample at $280 \mathrm{m \mu}$ was 1550 units. $20 \mathrm{ml}$ fractions were taken at a rate of $5 \mathrm{ml} / \mathrm{min}$. The gradient was obtained by the use of $3052 \mathrm{ml} 0.01 \mathrm{M}$ phosphate (pH 5.5) in the mixing chamber and $0.6 \underline{\mathrm{M} \mathrm{NaCl}}$ in $0.12 \mathrm{M}$ phosphate in the reservoir.

by application of the gradient. All tubes were read at 240,260 , and $280 \mathrm{~m} \mu$. Changes in ratios across the peak are indicative of a lack of homogeneity. The $280 / 260$ ratio is 1.62 at tube $36,1.65$ at tube 38 , and 1.45 at tube 41 . The appreciable drop in tube 41 appears to indicate the presence of an impurity. Conductivities of various fractions were measured. The value at tube 35 , in which the peak is beginning to emerge, corresponds to that for $0.07 \mathrm{M}$ sodium chloride.

Fearing that the gradient used in the experiment summarized by Figure .5 was too sharp and thus reduced the resolution of the compounds, another column was used with a more moderate gradient. The pattern is shown in Figure 6 . Here the peak is broader, but there is no indication of other components.

(b) Spectral-transmittance curves in the ultraviolet. The absorption curve for the Step 1 product is featureless in the range 230 to $320 \mathrm{~m} \mu$. There is no indication of the $280 \mathrm{~m} \mu$ maximum that is typical of proteins and results from their tyrosine and tryptophane content. However, the active fractions from rerun DEAE-columns show the typical protein pattern. The curve for such a frac- 


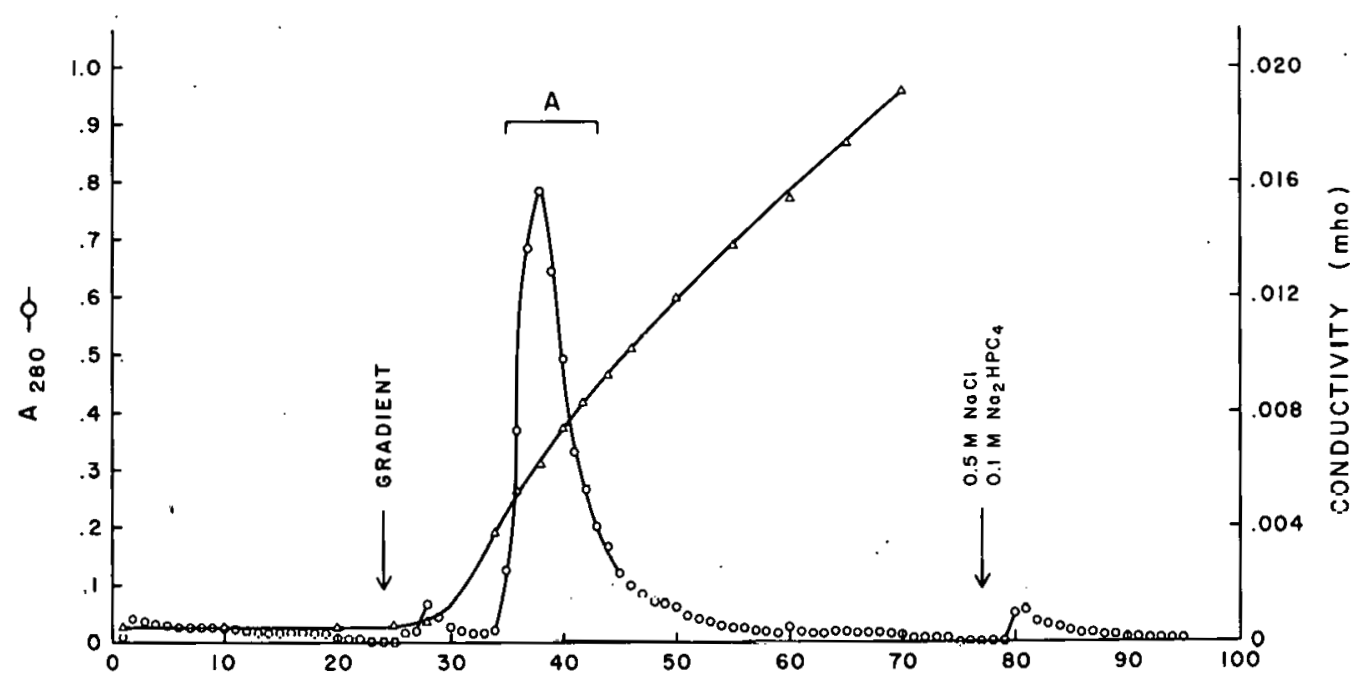

Figure 5. First analytical rechromatography of fraction B (Figure 4). $20 \mathrm{mg}$ of the fraction in $10 \mathrm{ml} 0.01 \mathrm{M}$ phosphate at $\mathrm{pH} 5.5$ was applied to a column $10 \mathrm{~cm}$ high $\times 0.9 \mathrm{~cm}$ diam. The total optical density of the sample solution at $280 \mathrm{~m} \mu$ was 15.5 units. Gradient elution was obtained by the use of $218 \mathrm{ml} 0.01 \mathrm{M}$ phosphate (pH 5.5) in the mixing chamber and $0.6 \mathrm{M} \mathrm{NaCl}-0.12 \mathrm{M}$ phosphate in the reservoir.

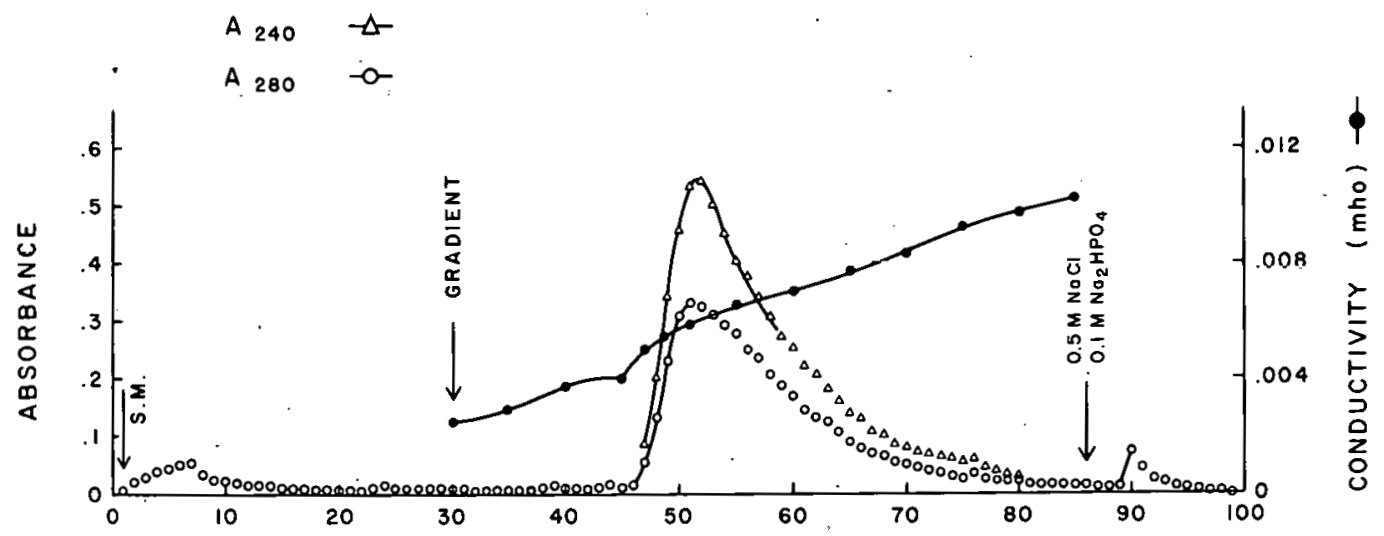

Figure 6. Second analytical rechromatography of fraction $B$ (Figure 4). All conditions the same as in the experiment of Figure 5 except that 0.25 $\underline{\mathrm{M} \mathrm{NaCl}}$ was used in the reservoir instead of $0.6 \underline{\mathrm{M}} \mathrm{NaCl}$.

tion (fraction, Figure 4) is illustrated in Figure $7 .^{*}$ The spectrum was determined on a solution of $0.50 \mathrm{mg}$ per $\mathrm{ml}$ of $\mathrm{pH} 7.0$ buffer. The $\mathrm{A}_{280} / \mathrm{A}_{260}$ ratio is 1.75 and the $A_{1}^{1 \%} \mathrm{~cm}$ value at $280 \mathrm{~m} \mu$ is 8.6 . Since the material in the leading edge of the DEAE elution peak (Figure 4, fraction $B$ ) shows an absorption curve with definite maximum and minimum and since the curve of the parent Step 1 material is featureless, it is obvious that at least one of the other DEAE fractions must have a

* Before being tested in the spectrophotometer, fraction B was subjected to fractional electrical transport to remove salts. 


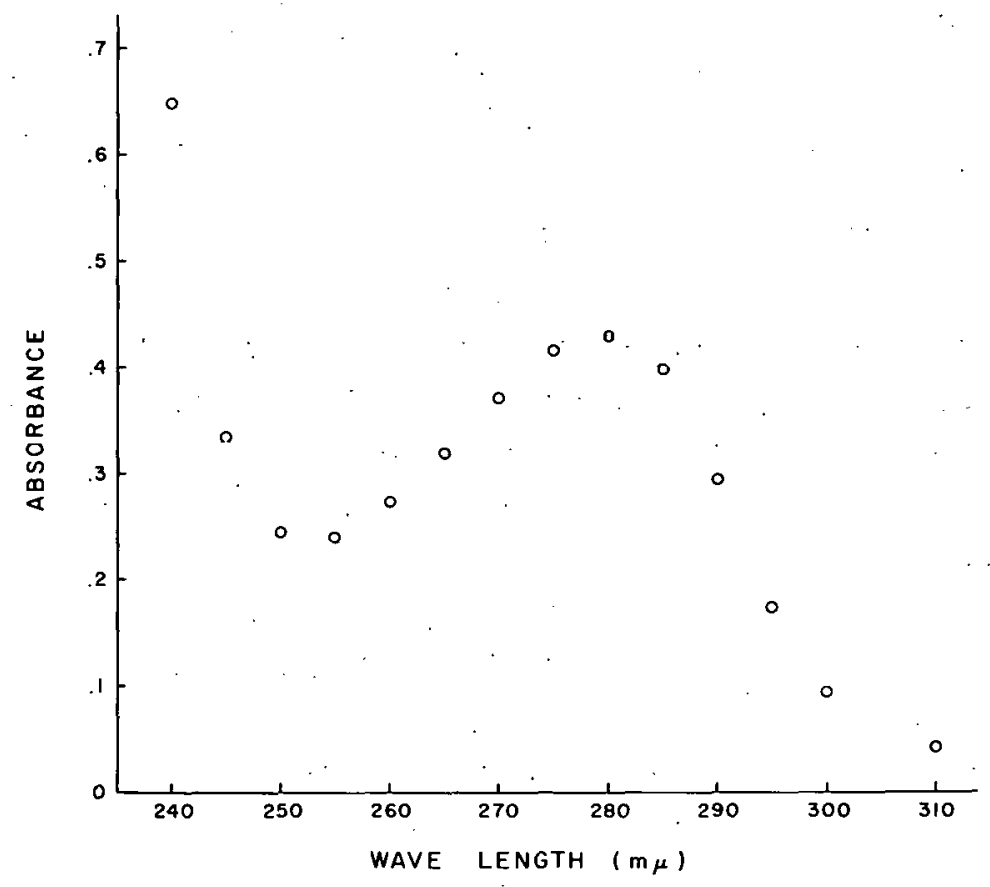

Figure 7. Ultraviolet absorption spectrum of Step 3 material. Fraction B (cf. Figure 4) at $0.50 \mathrm{mg} / \mathrm{ml}$ in $\mathrm{pH} 7.0$ buffer.

strong absorption, which is qualitatively different, in order to obscure the protein-like curve of the active fraction. Accordingly, the other DEAE fractions were tested, with the results shown in Table 2. It is clear from the data that the biologically inert fractions $A$ and $F$ are responsible for the featureless charac-

Table 2

ULTRAVIOLET ABSORPTION DATA FOR FRACTIONS. OBTAINED BY RE-CHROMATOGRAPHY OF STEP 1 MATERIAL. ON DEAE-CELLULOSE

\begin{tabular}{|c|c|c|c|}
\hline Fraction $^{*}$ & Description & $\mathrm{E}_{1 \mathrm{~cm}}^{1 \%}(280 \mathrm{~m} \mu, \mathrm{pH} 7)$ & $\mathrm{A}_{280} / \mathrm{A}_{260}$ \\
\hline $\mathrm{A}$ & Unadsorbed & 10.2 & 1.01 \\
\hline B & $\begin{array}{l}\text { Leading edge of } \\
\text { gradient peak }\end{array}$ & 8.6 & 1.75 \\
\hline $\begin{array}{l}\mathrm{C} \\
\mathrm{D} \\
\mathrm{E}\end{array}$ & $\begin{array}{l}\text { Portions of } \\
\text { trailing edge } \\
\text { of gradient peak }\end{array}$ & $\begin{array}{l}7.0 \\
6.5 \\
5.4\end{array}$ & $\begin{array}{l}1.32 \\
1.05 \\
0.91\end{array}$ \\
\hline $\mathrm{F}$ & $\begin{array}{l}\text { Peak eluted by } \\
\text { very high salt }\end{array}$ & 9.4 & 0.70 \\
\hline
\end{tabular}

\footnotetext{
*Fractions of chromatographic separation (Figure 4).
} 
teristic of the Step 1 curve. Also, it appears from the data that the most potent fractions have the highest $280 / 260$ ratios.

3. The use of IRC-50 (XE-97). Preliminary data obtained from experiments on the role of the carboxylic cation exchanger in the purification of erythropoietin are summarized in Table 3. As the $\mathrm{pH}$ of the resin was lowered, more and more of the erythropoietic activity was adsorbed, and this could not be eluted. For instance, at pH's $6.8,6.4$, and 6.0 no activity was adsorbed, whereas at $\mathrm{pH} 5.5,50$ per cent of the activity was adsorbed and at 5.0, 100 per cent. In no case could the activity be desorbed by conventional chromatographic methods. Table 3 also shows a rather positive correlation between the per cent of protein unadsorbed and biologic activity of the effluent.

Figures $8 \mathrm{~A}$ and $8 \mathrm{~B}$ may be used to compare the electrophoretic analyses of Step 1 material with a preparation after it had passed through an XE-97 column at $\mathrm{pH} 6.0$ or 6.4. The second electrophoretic peak of the original material was removed by the pH 6.0 column; a large percentage of the protein comprising the more slowly moving peak was removed at $\mathrm{pH}$ 6.4. Since no erythropoietic activity was lost in either of these preparations, it was again concluded that the second
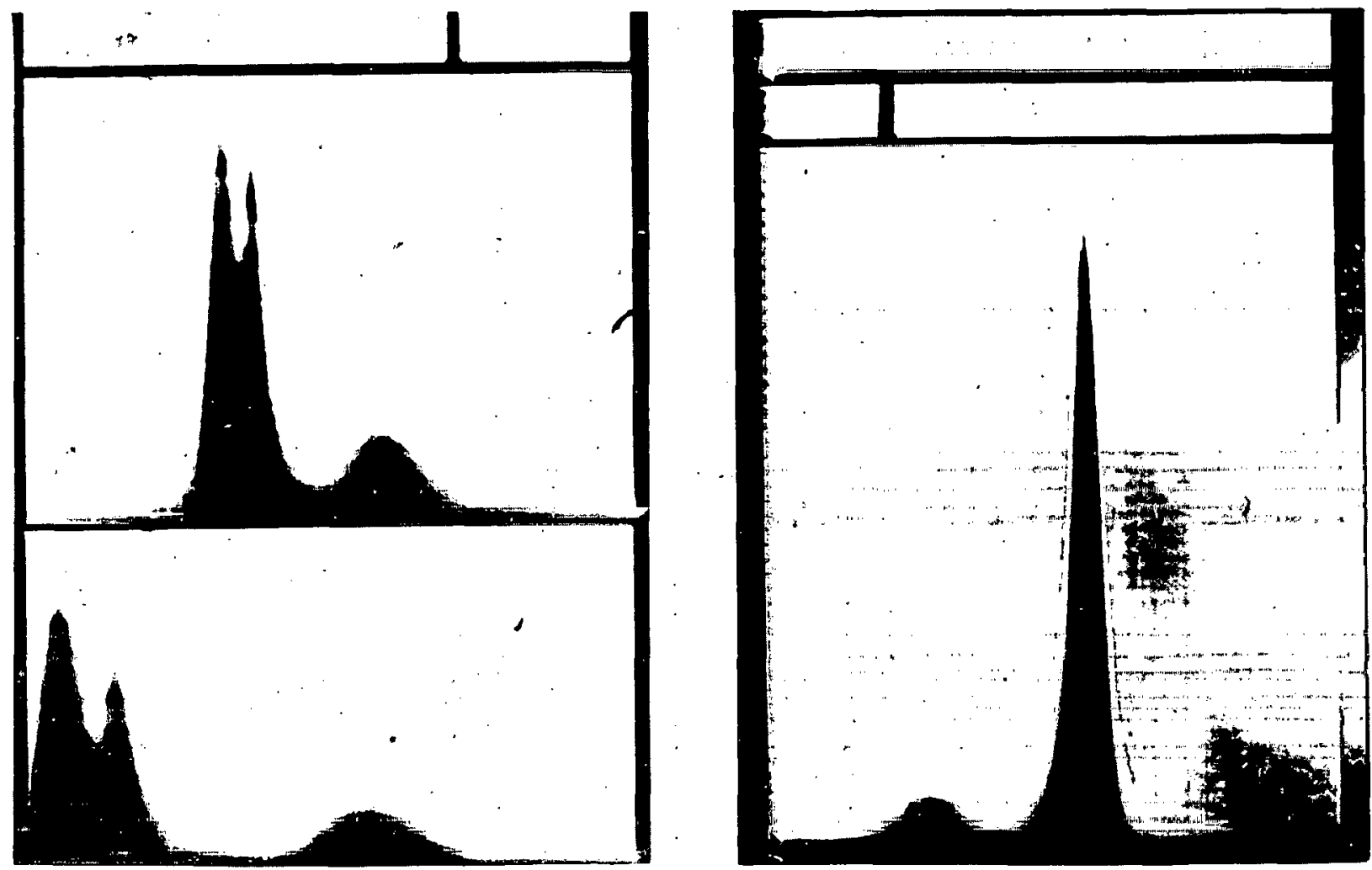

Figure 8. Electrophoretic analyses of sheep erythropoietin fractions. pH 8.5,0.1 M veronal buffer. Descending limb. A. Step 1 fraction $u=$ 6.9 and $5.2 \cdot 0^{-5} \mathrm{~cm}^{2} \mathrm{sec}^{-1}$ volt ${ }^{-1}$. B. Material unadsorbed on XE-97 at $\mathrm{pH} 6.0 \mathrm{u}=7.0 \times 10^{-5}$. 
Table 3

COLUMN CHROMATOGRAPHY OF STEP 1 MATERIAL ON XE-97

\begin{tabular}{|c|c|c|c|c|c|c|c|}
\hline \multirow{2}{*}{$\mathrm{pH}$} & \multirow{2}{*}{ Buffer composition } & \multirow{2}{*}{ Fraction } & \multicolumn{2}{|c|}{$\%$ Recovery } & \multicolumn{3}{|c|}{ Assay data } \\
\hline & & & O.D. & Wt. & $\begin{array}{c}\text { Dose } \\
(\mathrm{mg} / \mathrm{rat})\end{array}$ & $\begin{array}{l}\text { Potency } \\
(u / m g)\end{array}$ & $\%$ Recovery \\
\hline $\begin{array}{l}5.0 \\
5.6\end{array}$ & $\begin{array}{l}0.03 \text { M Citrate } \\
0.5 \quad \underline{M} \text { Citrate }\end{array}$ & $\begin{array}{l}\text { Effluent } \\
\text { Eluate }\end{array}$ & $\begin{array}{r}23 \\
8\end{array}$ & - & $*$ & $\begin{array}{l}0 \\
0\end{array}$ & $\begin{array}{l}0 \\
0\end{array}$ \\
\hline 5.2 & $0.25 \mathrm{M}$ Phosphate & Effluent & 52 & 39 & 1.0 & 0.1 & 10 \\
\hline 5.5 & $0.25 \underline{\mathrm{M}} \mathrm{Na}$ Phosphate & Effluent & 46 & 42 & 1.1 & 0.8 & 50 \\
\hline $\begin{array}{c}6.0 \\
(7.0)\end{array}$ & $\begin{array}{l}0.2 \quad \mathrm{M} \\
0.2 \quad \underline{\mathrm{M}} \mathrm{PO}_{4} \stackrel{\text { Phosphate }}{\mathrm{pH} 7}\end{array}$ & $\begin{array}{l}\text { Effluent } \\
\text { Batch eluate }\end{array}$ & $\begin{array}{l}50 \\
25\end{array}$ & - & $\begin{array}{l}1.4 \\
-\end{array}$ & $\begin{array}{l}1.2 \\
0\end{array}$ & $\begin{array}{r}100 \\
0\end{array}$ \\
\hline 6.4 & $\begin{array}{l}0.2 \quad \mathrm{M}_{0} \mathrm{NaPO}_{4} \\
0.2 \quad \underline{\mathrm{M}} \mathrm{NaPO}_{4}\end{array}$ & $\begin{array}{l}\text { Effluent (peak) } \\
\text { Effluent (tail) }\end{array}$ & $\begin{array}{r}66 \\
6\end{array}$ & $\begin{array}{l}60 \\
22\end{array}$ & $\begin{array}{c}2.1 \\
-\end{array}$ & 1.2 & $\begin{array}{c}100 \\
-\end{array}$ \\
\hline 6.8 & $\begin{array}{l}0.02 \mathrm{M} \mathrm{NaPO}_{4} \\
0.02 \underline{\mathrm{M}} \mathrm{NaPO}_{4} ; 0.5 \mathrm{M} \mathrm{NaCl}\end{array}$ & $\begin{array}{l}\text { Effluent } \\
\text { Eluate }\end{array}$ & $\begin{array}{r}78 \\
8\end{array}$ & $\begin{array}{r}62 \\
-\end{array}$ & $\begin{array}{c}1.5 \\
-\end{array}$ & $\begin{array}{l}1.0 \\
0\end{array}$ & $\begin{array}{r}100 \\
0\end{array}$ \\
\hline \multicolumn{8}{|c|}{ Batchwise procedure } \\
\hline $\begin{array}{l}5.0 \\
6.0\end{array}$ & $\begin{array}{l}0.05 \underline{\mathrm{M}} \mathrm{NaPO}_{4} \\
0.2 \underline{\mathrm{M}} \mathrm{NaPO}_{4}\end{array}$ & $\begin{array}{l}\text { Unadsorbed } \\
\text { Eluted }\end{array}$ & $\begin{array}{l}48 \\
27\end{array}$ & $\begin{array}{l}27 \\
28\end{array}$ & $\begin{array}{l}0.7 \\
0.76\end{array}$ & 0 & 0 \\
\hline
\end{tabular}

* Doses based on equivalency of the parent Step 1 material. 
electrophoretic component is inactive: Re-chromatography experiments with the pH 6.0 effluent from XE-97 showed no further adsorption; hence it was assumed that the original $\mathrm{pH} 6.0$ effluent was apparently quite different from the adsorbed material and that its presence was not merely the result of exceeding the resin capacity.

The erythropoietin fraction with a single electrophoretic component had an unusual ultraviolet absorption spectrum in that there was virtually no minimum on the curve. Apparently, in removing the inactive protein component, an increase had occurred in the relative concentration of a component that absorbs anomalously in the ultraviolet. It had been observed earlier that the material that was unadsorbed at $\mathrm{pH} 5.0$ exhibited this behavior to such an extent that the A 280/260 ratio was less than unity. In most proteins this value falls between 1.3 and 2.5

Thus, by passage of Step 1 material through an XE-97 column at $\mathrm{pH} 6.0$, the slower inert electrophoretic peak is removed without loss of activity. In the process, approximately $1 / 2$ the solids of Step 1 material are removed. However, in the anaphylactic test, the purified product is still moderately antigenic, killing 3 out of 5 animals. In a similar test, the parent Step 1 product killed 5 out of 5 animals.

A three-step procedure for the production of a highly purified erythropoietin concen-

trate. Re-examination of the results of the preliminary experiments suggested that a combination of two DEAE steps and one XE-97 step should give a product that would be much less antigenic and which perhaps might also satisfy many of the criteria of protein homogeneity. The 3-step procedure diagrammed in Figure 9 was then devised. The process has been applied several times to plasma from anemic sheep: One example in which 8 liters of plasma were used is shown in Table 4. The initial plasma was part of a 25-liter batch produced as indicated in an earlier section of this report: The table shows the weight yields, potencies, and total units of activity at each step of the process. The overall concentration in terms of solids was $1370: 1$, and the overall yield in activity was 22.5 per cent.

Properties of third-stage sheep erythropoietin. Moving boundary electrophoresis in pH 8.5 0.1 M veronal buffer and in $\mathrm{pH} 5.50 .1 \mathrm{M}$ acetate buffer showed single, symmetrical peaks with no evidence of other components within the limits of detection by the refractive index gradient method (Figure 10).

Sedimentation-velocity determinations in the synthetic boundary cell in the same buffers as above gave single, symmetrical peaks, showing only one component. Figure 11 shows a peak at $\mathrm{pH} 5.5$ at a concentration of $10 \mathrm{mg} / \mathrm{ml}$ after 48 minutes of centrifugation at 59,780 $\mathrm{rpm}$ at $26^{\circ} \mathrm{C}$ : The concentration dependence of $\mathrm{S}$ is shown in Figure 12 with an extrapolated value of $\mathrm{S}_{20, \mathrm{w}}=3.7 \mathrm{~S}$.

An analytical chromatographic run on DEAE-cellulose (Figure. 13) shows a single component which has a constant A $280 / 260$ ratio of 2.2 throughout the peak.

Determinations of total carbohydrate by the carbazole method, ${ }^{7}$ using a mixture of glucose, mannose, galactose, and fructose as a standard, gave a value of 6.5 per cent. Sialic 


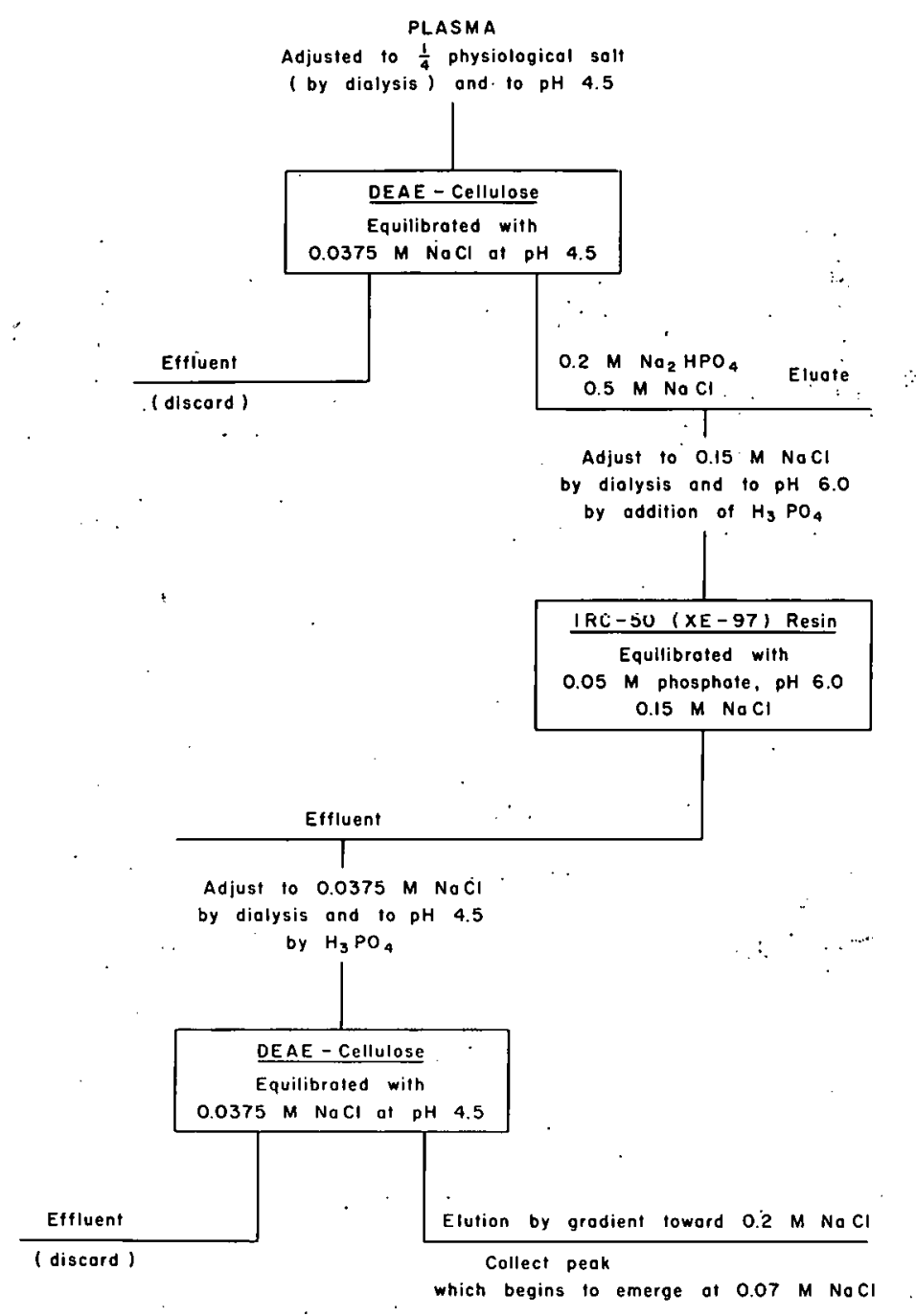

Figure 9. Three-step process for production of highly purified erythropoietin.

Table 4

EXAMPLE OF THREE-STEP PROCESS

\begin{tabular}{c|l|c|c|c|c}
\hline Stage & \multicolumn{1}{|c|}{ Description } & $\begin{array}{c}\text { Weight } \\
\text { yield } \\
\text { (g) }\end{array}$ & $\begin{array}{c}\text { Potency } \\
\text { (u/mg) }\end{array}$ & $\begin{array}{c}\text { Total } \\
\text { Activity } \\
\text { (units) }\end{array}$ & $\begin{array}{c}\text { Overall } \\
\text { Recovery } \\
\text { (\%) }\end{array}$ \\
\hline & Plasma & 640 & 0.0071 & 4560 & 100 \\
Step 1 & First DEAE eluate & 2.85 & 1.0 & 2850 & 63 \\
Step 2 & XE-97 effluent & 1.43 & 1.55 & 2230 & 49 \\
Step 3 & 2nd DEAE eluate & 0.46 & 2.23 & 1030 & 22.5 \\
\hline
\end{tabular}




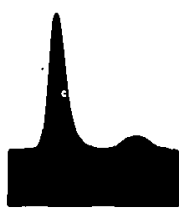

PH 8.5

$100 \mathrm{~min} .4 \mathrm{mo}$.

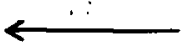

D

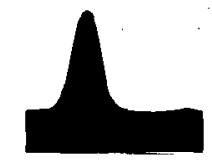

$\mathrm{PH} 5.5$

$200 \mathrm{~min} .4 \mathrm{mo}$.

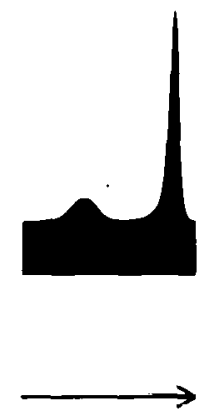

A

Figure 10. Electrophoresis of purified sheep erythropoietin (third stage) $\mathrm{pH} 8.5$ buffer is 0.1 M. veronal, pH 5.5 buffer is $0.1 \underline{\mathrm{M}}$ acetate.

acid, determined by the perchloric acid-tryptophane method, ${ }^{8}$ gave a value of 15 per cent, and by the Ehrlich's reagent method, 917 per cent. In both these determinations orosomucoid was used as a standard with an assumed sialic acid content of 11 per cent.

In the starved-rat assay, 3rd-stage material showed potencies of 2 to $10 \mathrm{u} / \mathrm{mg}$, depending on the potency of the original plasma. In the example in Table 4, where the starting plasma had an activity of $0.0071 \mathrm{u} / \mathrm{mg}$ solids, the Step. 3 product showed a potency of $2.23 \mathrm{u} / \mathrm{mg}$. This is a typical value for the product from our large plasma pools.

Assay in polycythemic mice ${ }^{10}$ at $250 \mu \mathrm{g} /$ mouse/day for 4 days resulted in a reticulocyte count of 2.0 per cent whereas saline controls had a value of 0.0 per cent.

Third-step material was only slightly antigenic whereas second-step material was still quite antigenic (Table 5).

\section{DISCUSSION}

By use of a relatively simple three-step procedure, a biologically active product was obtained that is homogeneous by three criteria, electrophoresis at $2 \mathrm{pH}$ values, sedimen- 


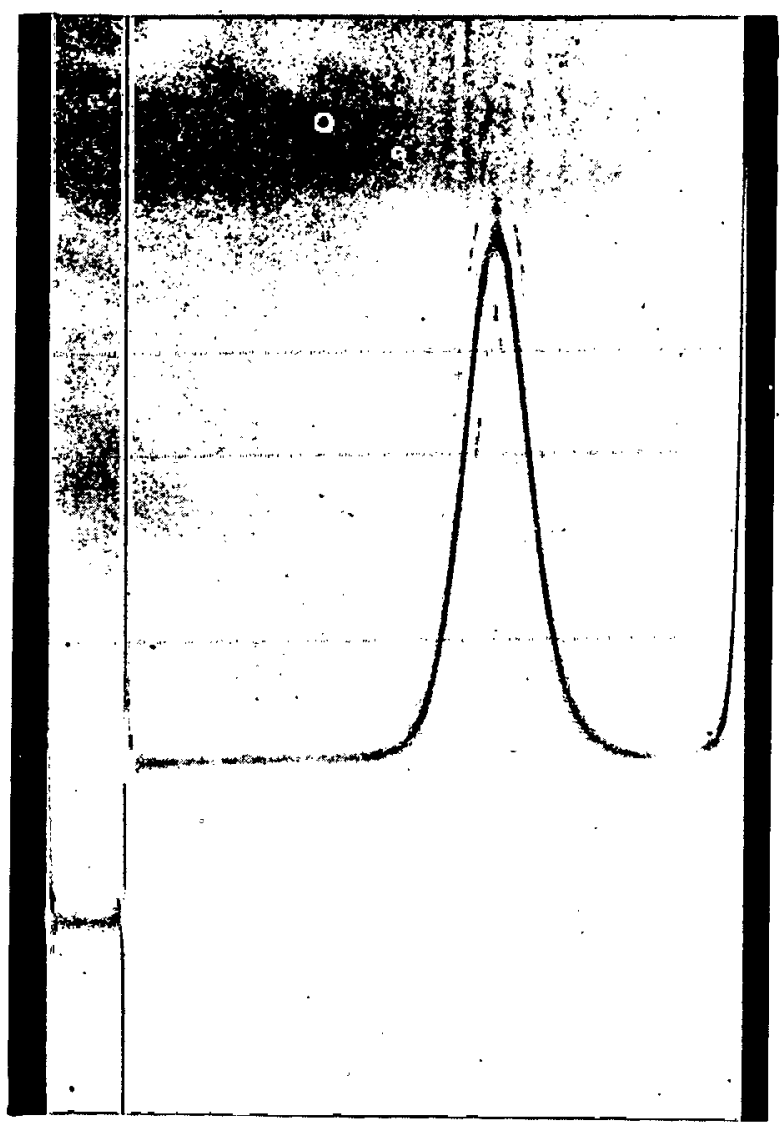

Figure 11. Sedimentation velocity ultracentrifuge pattern of Step 3 erythropoietin. Conditions of run: synthetic boundary cell, $10 \mathrm{mg} / \mathrm{ml}$ concentration, pH $5.50 .1 \mathrm{M}$ acetate buffer, $59,780 \mathrm{rpm}, 48 \mathrm{~min}, 26^{\circ}$.

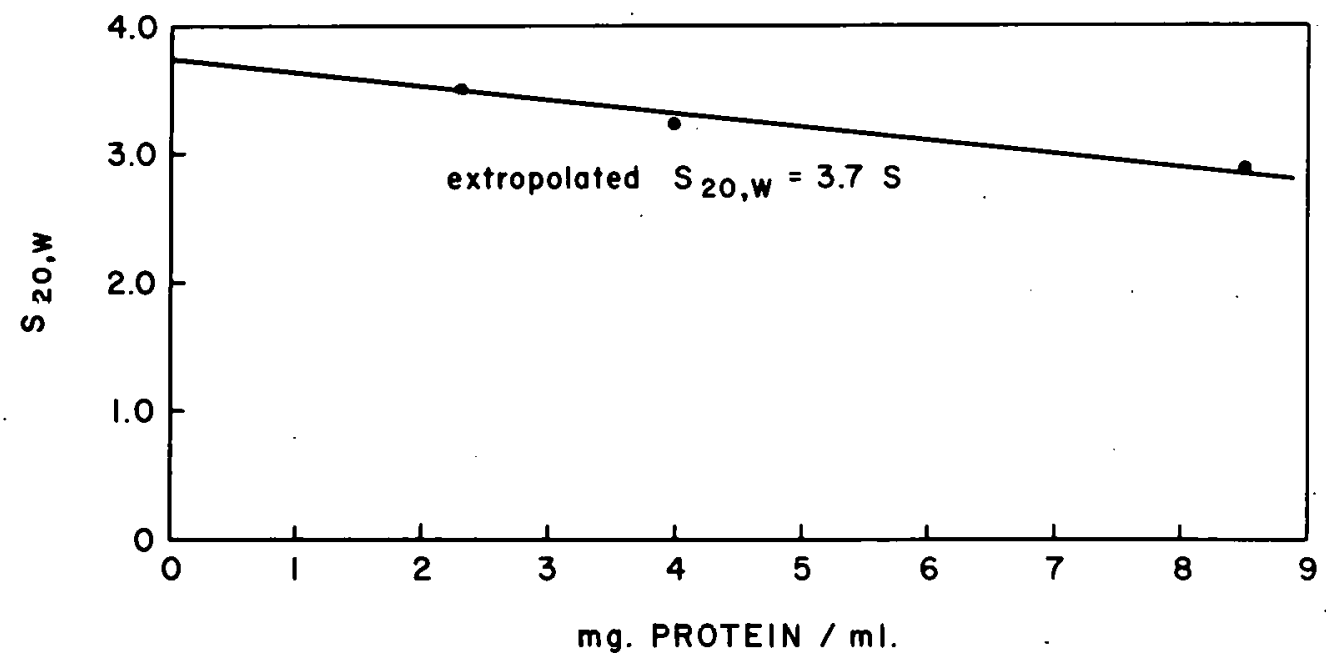

Figure 12. Concentration dependence curve of sedimentation coefficient of sheep erythropoietin (Third Stage). 


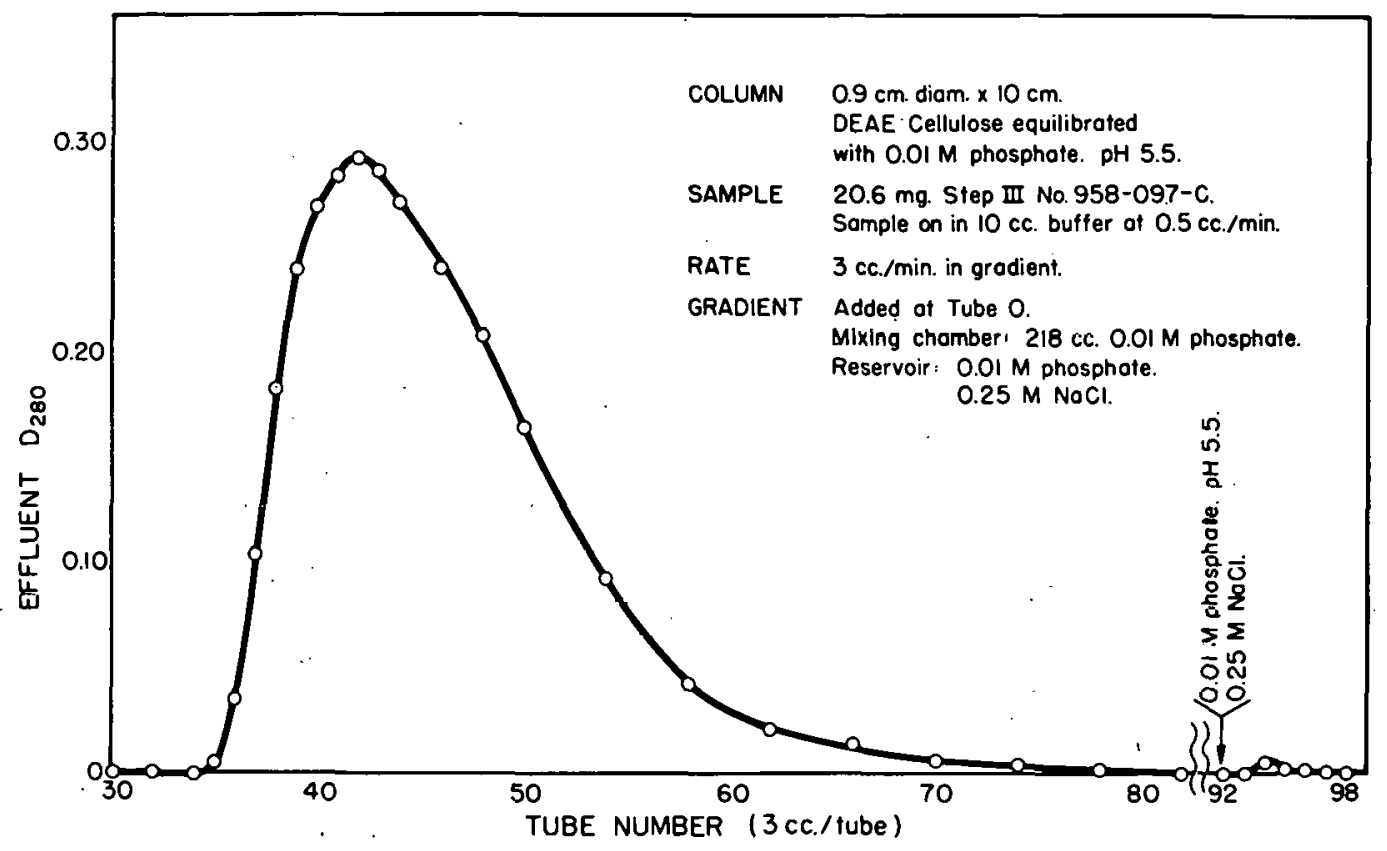

Figure 13. DEAE-cellulose rechromatography of Step 3 material.

tation velocity at $2 \mathrm{pH}$ values, and ion-exchange chromatography. Since unequivocal homogeneity cannot be established in the laboratory, we must demonstrate lack of heterogeneity. by as many different methods as possible. Of the methods already applied, only electrophoresis and ultra-centrifugation are, in reality, independent methods. Since the final product was derived from a cut of a DEAE-cellulose column fractionation, it is to be expected that it would yield a single chromatographic peak. However, the constancy of the $280 / 260$ ratio indicates lack of gross contamination. As more material becomes available, many other criteria and many other experimental conditions will be employed in a search for possible heterogeneity.

Two short papers ${ }^{11,12}$ have recently appeared on the purification of rabbit erythropoietin. In the first of these a highly active preparation was obtained with no data as to homogeneity, and in the second the material described was shown to have a single electrophoretic component at $\mathrm{pH} 8.6$ and to have a sialic acid content approximately the same as that we report here.

Another observation of ours tends to make discussion of the absolute purity somewhat premature. If normal sheep plasma is processed through the first step of the purification procedure, an inactive product is obtained which has electrophoretic and chromatographic properties indistinguishable from those of anemic plasma of high titer. Time has not yet permitted processing the inactive material from normal plasma through the complete purification procedure.

Our observations, incomplete as they are, lead us to 2 opposing hypotheses, only one of which seems feasible to test at this time: 1) We suggest that homogeneous as the final 
Table 5

GUINEA PIG ANAPHYLACTIC TEST

(300-g male animals used)

\begin{tabular}{|c|c|c|c|c|c|c|}
\hline \multirow{2}{*}{$\begin{array}{l}\text { Guinea pig } \\
\text { No. }\end{array}$} & \multicolumn{5}{|c|}{$\begin{array}{c}\text { Sample: Step } 3 \text { material } \\
\text { Response }\end{array}$} & \multirow{2}{*}{ Remarks } \\
\hline & Excitement & Cough & Bronchospasm & Collapse & Death & \\
\hline $\begin{array}{l}1 \\
2 \\
3 \\
4 \\
5 \\
\\
\\
1 \\
2\end{array}$ & $\begin{array}{l}\mathbf{v} \\
\mathrm{v} \\
\mathrm{v}\end{array}$ & $\begin{array}{l}\mathrm{v} \\
\mathrm{v} \\
\mathrm{v}\end{array}$ & v & . & & $\begin{array}{c}\text { No effect } \\
\text { No effect } \\
\qquad \\
\text { No effect } \\
\text { No effect }\end{array}$ \\
\hline \multirow[t]{2}{*}{$\begin{array}{l}\text { Guinea pig } \\
\text { No. }\end{array}$} & \multicolumn{5}{|c|}{$\begin{array}{c}\text { Sample: Step } 2 \text { material } \\
\text { Response }\end{array}$} & \multirow{2}{*}{ Remarks } \\
\hline & Excitement & Cough & Bronchospasm & Collapse & Death & \\
\hline $\begin{array}{l}1 \\
2 \\
3 \\
4 \\
5\end{array}$ & $\begin{array}{l}\mathrm{v} \\
\mathrm{v} \\
\mathrm{v} \\
\mathrm{v}\end{array}$ & $\begin{array}{l}\mathrm{v} \\
\mathrm{v} \\
\mathrm{v} \\
\mathrm{v}\end{array}$ & $\begin{array}{c}\mathrm{v} \\
\mathrm{v} \\
\mathrm{v} \\
\mathrm{v} \\
\text { Controls }\end{array}$ & $\begin{array}{l}\mathrm{v} \\
\mathrm{v} \\
\mathrm{v} \\
\mathrm{v}\end{array}$ & $\begin{array}{l}\mathbf{v} \\
\mathrm{v} \\
\mathrm{v} \\
\mathrm{v}\end{array}$ & $\begin{array}{l}\text { No effect } \\
\text { No effect } \\
\text { No effect }\end{array}$ \\
\hline
\end{tabular}

preparation may appear, it represents a normally-occurring acid glycoprotein to which is complexed a very minor component that is the active hormone. This suggestion is being studied in our laboratories. 2) Another possibility is analogous to the situation seen with the $\gamma$ globulins that may or may not be antibodies. This suggestion implies that, under the anoxic stimulus, the production of the normal a glycoproteins is shifted subtly to produce a physically and chemically identical protein having biologic activity built into it.

These questions of purity aside, the procedure outlined in this paper is sufficiently. good to yield a highly active non-antigenic material that is adequate for clinical trials.

\section{SUMMARY}

Conditions for the production of uniform high-titer anemic plasma from sheep have been described.

A simple three-step procedure for the purification of sheep erythropoietin has been developed.

An active preparation has been isolated that is non-anaphylactic in guinea pigs and 
that is homogeneous by electrophoresis and sedimentation at $\mathrm{pH}$ values of 5.5 and 8.6. This material also appears homogeneous upon DEAE-cellulose chromatography.

Some properties of sheep erythropoietin are described and the question of its homogeneity is discussed.

\section{ACKNOWLEDGMENTS}

We appreciate the help of $\mathrm{H}$. Norgello and M. L. Wang.

\section{ADDENDUM}

Since this report was written, we have had some limited success in the resolution of Step 3 erythropoietin into a small amount of active material and a larger amuunt of inactive material. This suggests that the methods applied above for testing homogeneity are not sensitive enough to yield an unequivocal answer.

\section{LITERATURE CITED}

1. Fried, W., L. F. Plzak, L. O. Jacobson, and E. Goldwasser. Proc. Soc. Exp. Biol. Med., $94: 237,1957$.

2. Jacobsen, E. M., A. K. Davis, and E. L. Alpen. Blood, 11:947, 1956.

3. Borsook, H., A. Graybiel, G. Keighley, and E. Windsor. Blood, 9:734, 1954.

4. Sober, H. A. F. J. Gutter, M. M. Wycoff, and E. A. Peterson. J. Am. Chem. Soc., $78: 756,1956$.

5. Neurath, H., and K. Bailey, Eds. The Proteins, Vol. 1, A, p. 546. Academic Press, New York, 1953.

6. Kabat, E. A., and M. M. Mayer. Experimental Immunochemistry, Chapter 5, p. 140. Charles C. Thomas, Springfield, Illinois, 1948.

7. Ashwell, G., in Methods in Enzymology. Eds., Colowick and Kaplan, Vol. III, p. 80. Section C. Colorimetric Analysis of Sugars.

8. Seibert, F. B., M. L. Pfaff, and M. V. Seibert. Arch. Biochem., 18:279, 1948.

9. Werner, I., and L. Odin. Acta Soc. Med. Upsala., 57:230, 1952.

10. Jacobson, L. O., E. Goldwasser, L. Plzak, and W. Fried. Proc. Soc. Exp. Biol. Med., $94: 243,1957$.

11. Lowy, P. H., G. Keighley, H. Bor sook, and A. Graybiel. Nature, 181, 1802, 1958.

12. Rambach, W. A., J. A. D. Cooper, and H. L. Alt. Proc. Soc. Exp. Biol. Med., 98:602, 1958. 


\section{SUMMARY}

1. A relatively rapid and sensitive method of assay for erythropoietin has been developed, using the rate of incorporation of $\mathrm{Fe}^{59}$ into the red cells of normal, hylophysectomized, or starved rats as a measure of the rate of erythropoiesis.

2. Some of the factors that control erythropoiesis through control of production of erythropoietin have been studied. An hypothesis that the steady state of red cell formation is controlled by the relationship of the tissue demand for oxygen to the supply of oxygen available rather than by either factor alone has been presented with experimental data to substantiate it.

3. The effect of erythropoietin in initiating marrow activity of mice made polycythemic by red cell transfusion, and which have a completely suppressed marrow as far as red cell formation is concerned, has been demonstrated. This observation was made the basis for a rigorous and sensitive assay for erythropoietin. Evidence suggesting that the depression of erythropoiesis, following transfusion-induced polycythemia, is the direct consequence of a reduction in the erythropoietin titer has been presented.

4. The effect of cobalt in producing polycythemia has been found to be due to the stimulation of erythropoietin production by the metal ion. The time course of such production has been determined and found to be quite rapid, with peak erythropoietin production occurring at $10-12$ hours after cobaltous chloride administration.

5. The site of erythropoietin production has been studied by stimulating animals with either cobalt, hemorrhage, or hypoxia after extirpation of various organs. The only organs whose removal abolished the response to these stimuli were the kidneys. Animals with uremia comparable to the nephrectomized animals were prepared by bilateral ureter ligation and were found to respond to the above stimuli about as well as normal animals, indicating that it is not the uremia itself that interferes with erythropoietin formation. The disappearance of erythropoietin from the circulation of nephrectomized animals follows the same time course as that seen in normal animals. The data suggest very strongly that the kidney is the site of erythropoietin formation or at least is very greatly involved in its production.

6. The clinical significance of erythropoietin has been considered. Erythropoietin was found to be present in nurmal human plasma, and its titer was found to be elevated in some, but not all plasmas from anemic patients. At the present state of knowledge and with current techniques, however, one must be cautious in assessing the significance of the absence of erythropoietin from the plasma of anemic patients.

7. When transfusion-induced polycythemic female mice are mated, the fetuses they bear are capable of initiating and maintaining erythropoiesis in spite of the fact that the mothers' red cell production is completely suppressed due to the cessation of maternal erythropoietin formation. This observation suggests that fetuses in utero can produce their own erythropoietin. 
8. A simple method for measuring iron absorption in mice has been developed. While stimuli, such as bleeding, cobalt, intravenous hemolysis, and hypoxia are capable of increasing the gastrointestinal absorption of dietary iron, exogenous erythropoietin has no such effect. This makes it unlikely that erythropoietin has a direct effect on iron absorption.

9. When marrow cells are grown in culture for short times, the addition of plasma containing erythropoietin causes an increase in erythropoietic activity over that seen with normal plasma. Conversely, plasma from polycythemic animals causes a decrease in erythropoicsis.

10. The isolation of erythropoietin from anemic sheep plasma has progressed far enough to yield a product suitable for clinical testing. The purified material is non-antigenic for guinea pigs and is homogeneous by electrophoresis, column chromatography, and ultracentrifugal analysis. While the data are insufficient for a definitive statement about the absolute purity of this preparation, we suggest that it is not in a final state of purification. 


\section{O'THER PUBLICATIONS}

Goldwasser, E., L. O. Jacobson, W. Fried, and L. Plzak. Mechanism of the erythropoietic effect of cobalt. Science, 125:1085, 1957.

Gurney, C. W. The dynamic equilibrium of erythropoiesis: Studies of its theoretical and clinical significance. Proc. Inst. Med. Chicago, 22:58, 1958.

Gurney, C. W. The physiologic and clinical significance of erythropoietin. Ann. Internal Med., 49:363, 1958.

Jacobson, L. O., and E. Goldwasser. The dynamic equilibrium of erythropoiesis. Symposium on homeostatic mechanisms, Brookhaven National Laboratory Symposia, 10: $110,1957$.

Jacobson, L. O., E. Goldwasser, W. Fried, and L. Plzak. The role of the kidney in erythropoiesis. Nature, 179:633, 1957.

Jacobson, L. O., E. Goldwasser, W. Fried, and L. F. Plzak. Plasma factors influencing erythropoiesis. Proc. Sixth Cong. International Soc. Hematol., 1956, p. 777, Grune and Stratton, New York, 1958.

Jacobson, L. O., E. Goldwasser, C. $\dot{W}$. Gurney, W. Fried, and L. Plzak. Studies on erythropoietin (the hormone regulating red cell production). To appear in a monograph of The New York Academy of Sciences.

Jacobson, L. O., L. Plzak, W. Fried, and E. Goldwasser. Plasma factor(s) influencing red cell production. Nature, 177:1240, 1956.

Schroeder, L. R., C. W. Gurney, and N. Wackman. Assay of erythropoietin in bone marrow suspensions. Nature, 181:1537, 1958. 